\title{
Assessment of Viability of Microorganisms Employing Fluorescence TeChNiQues
}


Promotor: $\quad$ dr ir F.M. Rombouts

Hoogleraar in de levensmiddelenhygiëne en -microbiologie

Co-promotor: dr T. Abee

Universitair docent levensmiddelenmicrobiologie 


$$
\text { pNo } 820^{\prime} \cdot 2155
$$

Pieter Breeuwer

\section{Assessment of Viability of Microorganisms EMPloying Fluorescence TeChNIQUeS}

\section{Proefschrift}

ter verkrijging van de graad van doctor

op gezag van de rector magnificus, dr C.M. Karssen, in het openbaar te verdedigen op vrijdag 18 oktober 1996 des namiddags te half twee in de Aula van de Landbouwuniversiteit te Wageningen. 
Part of the research described in this thesis was financially supported by the E.C. mobility grant B/AGRE-910059 in the framework of the ECLAIR programme.

Front cover photos

top left:

Lactobacillus casei labelled with carboxyfluorescein

center middle: Germinating Rhizopus oligosporus sporangiospores stained with carboxyfluorescein.

Bottom right: $\quad$ Saccharomyces cerevisiae labelled with carboxyfluorescein

Back cover photos

top right:

Escherichia coli stained with a bisbenzimidazole.

center middle:

bottom left:

Lactococcus lactis labelled with ethidium bromide.

Germinated Rhizopus oligosporus sporangiospores stained with carboxyfluorescein.

Background:

autofluorescent cyanobacteria.

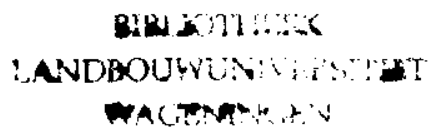

ISBN 90-5485-585-1 
Ter nagedachtenis aan mijn moeder aan mijn opa 


\subsection{0 $\cdot 215=$}

\section{Stellingen}

1. Bij het bepalen van de intracellulaire $\mathrm{pH}\left(\mathrm{pH}_{\mathrm{in}}\right)$ van micro-organismen met behulp van fluorescente probes dient de calibratie van de $\mathrm{pH}_{\text {in }}$ te worden uitgevoerd door meting van de $\mathrm{pH}$-afhankelijke fluorescentie in cellen na equilibratie van de $\mathrm{pH}_{\text {in }}$ en de $\mathrm{pH}_{\text {uit }}$ en niet door meting van de fluorescentie van de probe in buffer.

Imai, T, and Ohno, T. 1995. Measurement of yeast intracellular $\mathrm{pH}$ by image processing and the change it undergoes during growth phase. J. Biotechnol. 38:165-172.

Dit proefschrift

2. To create false color images, true data are required.

3. Door de opkomst van steeds sterkere schaakprogramma's wordt de kracht van de tegenstander in een correspondentieschaakpartij steeds meer bepaald door de kwaliteit van zijn/haar computer.

4. De onderzoeksresultaten van McKay et al. (1996) van de NASA over het voorkomen van leven op Mars hebben meer waarde voor "fund raising" dan als bewijs dat er microbiëel leven heeft bestaan op deze planeet.

McKay et al. 1996. Search for past life on Mars: possible relic biogenic activity in Martian meteorite ALH84001. Science 273:924-930.

Reichhardt, T. 1996. Lacks of Funds for technology could undermine Mars Mission Science. Nature $382: 481$.

5. Om verwarring met de fluorescente vorm van "fluorescein" te voorkomen is het aan te bevelen bij de naamgeving van gereduceerde niet-fluorescente fluoresceïne derivaten het voorvoegsel dihydro (b.v. "dihydrofluorescein") te hanteren in plaats van het veel gebruikte "fluorescin".

6. Nilsson et al. (1991) zien bij hun bewijs van een "viable but non-culturable state" van Vibrio vulnificus over het hoofd dat deze cellen na een eenvoudige resuscitatie wel degelijk "culturable" zijn.

Nilson, L., J.D. Oliver, and S. Kjelleberg. 1991. Resuscitation of Vibrio vulnificus from the viable but non-culturable state". J. Bacteriol. 173:5054-5059. 
7. In plaats van drinkwater te importeren vanuit Noorwegen naar Nederland in zakken van 100.000 liter via de Noordzee zouden de inspanningen om schoon oppervlaktewater in Nederland te verkrijgen sterk verhoogd moeten worden.

De Volkskrant 3 juli 1996.

8. Bij levensmiddelen die worden aangeprezen door met wetenschappelijk onderzoek onderbouwde gezondheidsclaims dient dit onderzoek volgens het "peer" review systeem te zijn beoordeeld.

9. Het verschil tussen schaatsen en skeeleren is dat skeeleren schaatsen op wieltjes is maar schaatsen geen skeeleren op ijzers.

10. Het onvoorwaardelijk afwijzen van euthanasie is geen keus voor het leven, maar een gebrek aan medemenselijkheid.

Stellingen behorende bij het proefschrift

'Assessment of Viability of Microorganisms Employing Fluorescence Techniques'

Pieter Breeuwer

Wageningen, 18 oktober 1996 


\section{Voorwoord}

In het projectvoorstel voor de "training en mobility" beurs van de E.G. stond heel voorzichtig geschreven: "Resultant publications will serve for the partial fulfilment of a doctoral thesis". Toen was nog geheel onduidelijk hoe het proefschrift afgemaakt zou worden. Maar met de steun van vele personen is het toch gelukt. Een aantal personen wil ik hier graag met name noemen.

Tjakko, je kwam precies op het goede moment om het onderzoek de nieuwe en kritische impuls te geven die nodig was. Ik heb ontzettend veel geleerd in de afgelopen periode en jouw bijdrage aan dit proefschrift kan nauwelijks overschat worden. Het doet mij dan ook veel plezier dat jij co-promotor wilde zijn.

Zonder promotor ook geen promotie. Ik wil Frans Rombouts graag bedanken voor zijn grote vertrouwen dat dit boekje er zou komen. De mogelijkheid die mij geboden werd om nog anderhalf jaar door te gaan op de vakgroep zijn daarbij onmisbaar geweest.

I like to express my gratitude to John Goodhardt for giving me the opportunity to work on my thesis at Chemunex, and I am specially indebted to Louis Foissac for giving his full support to this project. It has been a very valuable experience for me to work in France.

Jean Louis Drocourt, nous avons eu beaucoup de discussions pour trouver l'équilibre entre les interêts de Chemunex et mes interêts personnels. Je pense que cette thèse montre que c'était possible. Merci pour votre support.

Sophie, je te remercie pour toute ton aide et ton amitié. J'ai apprécié beaucoup l'effort que tu as fait pour traduire le résumé.

Corinne Laplace-Builhé, c'était un plaisir de discuter avec toi de la coloration fluorescente des microorganismes, mais pour moi les sorties à Fontainebleau sont encore plus mémorables.

Je remercie tout le personnel de Chemunex pour l'aide qu'il m'a apporté pour finir ma thèse.

Bob van Hengel, onze vele discussies over Chemunex, mijn proefschrift en andere dingen hebben mij veel geholpen.

De doctoraalstudenten Natascha Bunschoten en Yvette Zijerveld wil ik bedanken voor hun bijdrage aan het onderzoek.

De metingen met de "flow cytometer" bij de vakgroep Experimentele Diermorfologie en Celbiologie zijn mogelijk gemaakt door de deskundige hulp van Ellen Harmsen en Jan Rombout. 
Ton Visser en Eduard Pap van de vakgroep Biochemie hebben mij geholpen bij de allereerste $\mathrm{pH}_{\text {in }}$ metingen met de spectrofluorimeter. Ik had toen nog niet kunnen vermoeden dat het er uiteindelijk zo veel zouden worden.

Marcel Zwietering en Johan de Reu wil ik bedanken voor hun onuitputtelijke geduld als ik weer eens langskwam met een wiskundig of ander probleem.

Zonder de professionele hulp van Boudewijn van Veen zou de voorkant van dit boekje er heel anders uitgezien hebben.

Aidan Coffey, I enjoyed very much our discussions during your stay in our laboratory. Thanks again for all your efforts to correct those terrible manuscripts.

Mijn (ex)kamergenoten Martijn van Iersel en Johan van der Vlag. Jullie hebben mijn proefschriftstress van dichtbij meegemaakt en ik wil jullie bedanken voor de vele discussies en hulp die ik van jullie heb gehad.

En dan zijn er nog al die andere collega's die de vakgroep maken tot wat het is, een plek waar het goed werken is.

$\mathrm{Pa}$, onze lange gesprekken gaan gelukkig niet altijd over mijn werk, maar toch vaak ook wel. Je hebt me meer dan eens weer uit de put gepraat. Bedankt.

Last but not least. Flor, jouw morele hulp was veel belangrijker dan je zelf ooit beseft hebt. Muchísimo Gracias ! 


\section{Abstract}

Viability assessment of microorganisms is relevant for a wide variety of applications in industry, including evaluation of inactivation treatments and quality assessment of starter cultures for beer, wine, and yoghurt production.

Usually, the ability of microbial cells to reproduce is considered as the benchmark method for determination of cell viability, and this is most commonly determined by the plate count method. The time needed to form visible colonies, however, is relatively long. Therefore, there is an increasing interest in rapid methods which exploit criteria other than reproduction. The advantages of fluorescent methods are a high sensitivity, a high time resolution and the potential to analyze individual cells.

Fluorescent probes such as fluorescein, carboxyfluorescein (cF), and BCECF may be incorporated in microorganisms as (non-fluorescent) acetoxymethyl or diacetyl esters. These esters are membrane permeable and are cleaved in the cytoplasm by esterases, which results in accumulation of the fluorescent form. In Saccharomyces cerevisiae it was found that the carrier-mediated efflux of $\mathrm{cF}$ was coupled to the energy metabolism. Subsequently, a twostep procedure was developed, consisting of loading the cells with $\mathrm{cF}$, followed by incubation in the presence of glucose. The efflux experiments showed an excellent correlation between the viability of $S$. cerevisiae cells (determined by plate count) and the ability to translocate $\mathrm{cF}$.

The intracellular $\mathrm{pH}\left(\mathrm{pH}_{\mathrm{in}}\right)$ is critical for the control of many cellular processes, such as DNA transcription, protein synthesis, and enzyme activities. To determine the intracellular $\mathrm{pH}$ of bacteria a novel method was developed based on the intracellular conjugation of the fluorescent probe 5 (and 6-)-carboxyfluorescein succinimidyl ester (cFSE). This cFSE method significantly reduced problems due to efflux of fluorescent probe from the cells. Moreover, the method was successfully used to determine the intracellular $\mathrm{pH}$ in bacteria under stress conditions, such as elevated temperatures and the presence of detergents.

The viability of $R$. oligosporus sporangiospores was determined microscopically and with flow cytometry. Swelling of the sporangiospores was accompanied by an increase of the $\mathrm{pH}_{\text {in }}$. In the presence of nonanoic acid, a self-inhibitor produced by various fungi, an increase of the $\mathrm{pH}_{\mathrm{in}}$ was prevented and swelling inhibited, suggesting a crucial role of the $\mathrm{pH}_{\text {in }}$ in the germination of the spores.

The effects of detergents on the viability of Lactobacillus lactis and Bacillus subtilis were investigated. Triton X-100 and Lauryl sulfobetaine efficiently inhibited growth at concentrations below the critical micelle concentration. Surprisingly, the application of fluorescence techniques showed that Triton X-100 did not permeabilize the cytoplasmic membrane of L. lactis.

In conclusion, fluorescence techniques offer the possibility to study viability of a cell population employing microscopy, flow cytometry and image analysis. This may contribute to a better understanding of the mechanisms involved in selective survival of microorganisms under different stress conditions. 


\section{Contents}

Voorwoord

Abstract

Chapter 1 General introduction $\ldots \ldots \ldots \ldots \ldots \ldots \ldots \ldots \ldots \ldots \ldots \ldots \ldots \ldots$

Chapter 2 Characterization of uptake and hydrolysis of fluorescein diacetate and carboxyfluorescein diacetate by intracellular esterases in Saccharomyces cerevisiae, which result in accumulation of fluorescent product . . . . . . . . . . . . . . . . . . 29

Chapter 3 Energy-dependent, carrier-mediated extrusion of carboxyfluorescein from Saccharomyces cerevisiae allows rapid assessment of cell viability by flow cytometry . . . . . . . . . . . . 45

Chapter 4 A novel method for continuous determination of the intracellular $\mathrm{pH}$ in bacteria with the internally conjugated fluorescent probe 5 (and 6-)-carboxyfluorescein succinimidyl ester . . . . . . . . . 61

Chapter 5 Nonanoic acid, a fungal self-inhibitor, prevents germination of Rhizopus oligosporus sporangiospores by dissipation of the $\mathrm{pH}$ gradient

Chapter 6 Role of the cell envelope in resistance of gram-positive bacteria

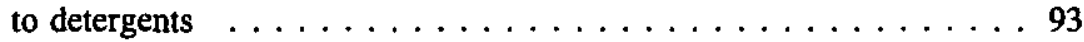

Chapter $7 \quad$ General discussion $\ldots \ldots \ldots \ldots \ldots \ldots$

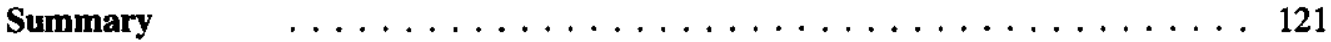

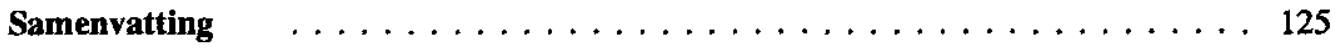

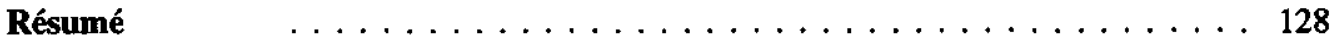

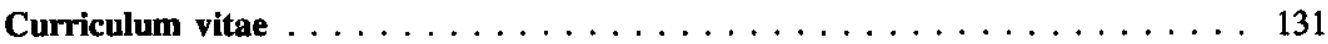




\section{1}

\section{General Introduction}

Part of this chapter will be submitted for publication as a review entitled "Assessment of viability of microorganisms employing fluorescence techniques", by P. Breeuwer and T. Abee. 


\section{Introduction}

In October 1678, Antoni van Leeuwenhoek (1632-1723) wrote in his letter to the Royal Society of London ".. and I must say, for my part, that no more pleasant sight has ever yet come before my eye than these many thousand of living creatures, seen all alive in a little drop of water, moving among one another, each creature having its own proper motion:...." (7). Van Leeuwenhoek, who was the first to describe bacteria, equated viability with motility. This belief was principally based on his early observations of human semen. He saw that those tiny, moving animals with a tail were all motionless after 2 to 3 hours, and supposedly dead (65). As it is, however, determination of viability of microorganisms turned out to be much more complex. This is nicely illustrated by the almost endless vocabulary which exists nowadays to describe the state of microorganisms, which includes terms as dead, moribund, starved, dormant, resting, quiescent, viable but non culturable, injured, sublethally damaged, inhibited, resuscitable, living, active, vital, etc. Viability assessment of microorganisms is crucial for applications such as detection and enumeration of food spoilage microorganisms, evaluation of inactivation treatments, quality assessment of starter cultures, biodegradation, production of antibiotics, and numerous others.

Viable cells can be generally defined as those cells which are capable of performing all cell functions necessary for survival under given conditions. Survival, in this respect, can be defined as the continuing existence of the species. Usually, the ability of cells to reproduce is considered as the benchmark method for determination of viability, and this is most commonly determined by the plate count method. The time needed to form visible colonies, however, is relatively long. On the other hand, microorganisms which do not form colonies, because they are dead, sublethally damaged, viable but non-culturable, dormant, inactive, etc., are not counted. Significantly, in natural environments such as soil or seawater this category of microorganisms is considered to be quite vast (116). Moreover, the viable plate count method can be frustrated by clumping, inhibition by neighbouring cells and composition of the used growth media (70). Therefore, there is an increasing interest in the development of rapid methods for the determination of cell viability. During the last decades, several methods have been developed which exploit criteria other than reproduction. These include methods based on membrane integrity, presence of membrane potential, and respiration.

This review will focus on the use of fluorescence techniques for the rapid assessment of viability of microorganisms. An introduction is presented to fluorescent probes used in microbiological research, and to the application of flow cytometry (FCM). Advantages of fluorescence techniques are a high sensitivity (i.e. the number of molecules needed for detection is relatively low), a high time resolution (approx. $10^{-8} \mathrm{sec}$.), and the potential to analyze individual cells in combination with such measurement techniques as FCM and image analysis. Fluorescent probes are exploited for various applications such as determina- 
tion of intracellular ion concentrations $\left(\mathrm{Ca}^{2+}\right.$, and $\left.\mathrm{H}^{+}\right)$, membrane potential measurements, in-situ hybridization, antibody labelling, and many others.

\section{Fluorescent probes}

Fluorescence can be defined as the emission of radiation upon molecular transition from the electronic excited state (not a triplet state, i.e. phosphorescence) to the ground state (Fig. 1). The unique feature of fluorescence is that the emission of radiation occurs at a higher wavelength (lower energy) than the wavelength of the incident radiation (excitation), which is needed to get the molecule in the excited state. This difference in wavelength is
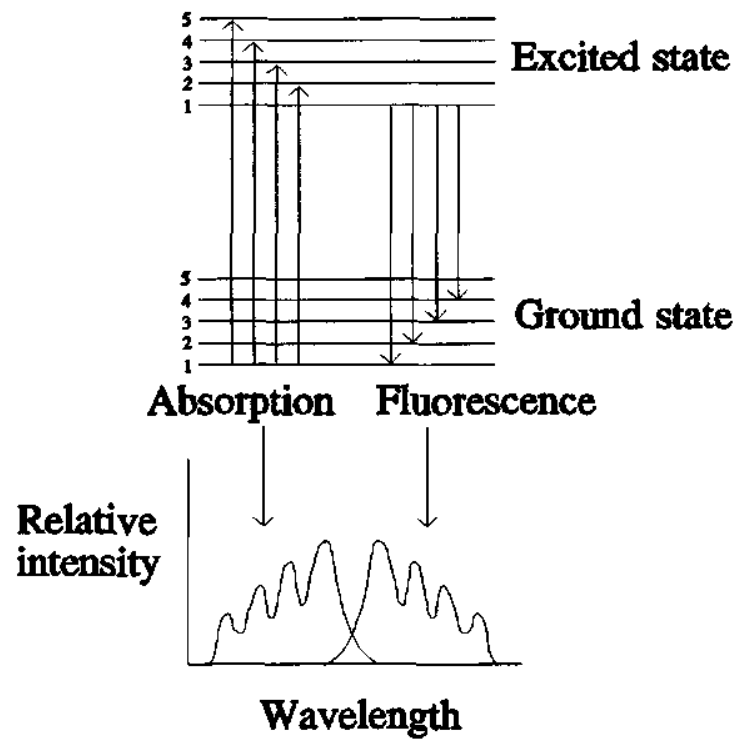

Fig. 1. Schematic representation of the fluorescence process. 
known as the Stokes shift. The fluorescence intensity $F(\lambda)$ (in $\mathrm{W} \mathrm{m}^{-2}$ ) is described by the equation:

$$
F(\lambda)=f(\theta) g(\lambda) \phi_{F} I_{0} \epsilon\left(\lambda_{a}\right) b C
$$

where $f(\theta)$ is a geometric factor, $g(\lambda)$ the Quantum efficiency of the detector, $\Phi$ the Quantum efficiency (Quantum Yield) of the fluorescent molecule (all dimensionless), $I_{0}$ the excitation intensity (in $\left.\mathrm{W} \mathrm{m} \mathrm{m}^{-2}\right),\left(\epsilon\left(\lambda_{\mathrm{a}}\right)\right.$ the molar absorption coefficient at the absorbing wavelength (in $\mathrm{m}^{2} \mathrm{~mol}^{-1}$ ), $b$ the optical pathlength (in $\mathrm{m}$ ), and $c$ the concentration of the fluorescent molecule (in $\left.\mathrm{mol} \mathrm{m}^{-3}\right)(13,16)$. This equation holds on the assumption that dyedye interactions and emission saturation of the fluorescent molecules do not occur (13). The Quantum yield is the ratio of the photons emitted through fluorescence to the total number of photons absorbed (thus, the maximum value of $\Phi$ is 1 ), and is highly dependent on environmental conditions.

The optimal $I_{0}$ of fluorescent probes is determined by their photostability and excited state lifetime $(\tau)$. Tsien and Waggoner (140) calculated from the $\epsilon, \Phi$, and $\tau$ of fluorescein that the laser power needed for optimal emission intensity is slightly less than $1 \mathrm{~mW}$ (assuming that triplet state formation is not occurring), which is much lower than usually applied. Furthermore, fluorescein can survive about $10^{4}$ to $10^{5}$ excited states before decomposition, which implies that more than $50 \%$ of the molecules will be damaged in less than $1 \mathrm{~ms}$ excitation by a $1 \mathrm{~mW}$ light source $(75,140)$. This illustrates that increasing the $I_{0}$ does not necessarily increase the fluorescence intensity.

Currently, a large variety of fluorescent molecules with very different spectroscopic properties is available for fluorescent labelling of microorganisms (Table 1). These probes exploit different cell properties such as existence of a membrane potential, activity of intracellular enzymes, respiratory activity, presence of mitochondria, integrity of the cytoplasmic membrane, composition of the cell wall, and presence of DNA and/or RNA to label the cells (Fig. 2 and 3). The probes can be arbitrarily classified into the following five groups:

1. Immunoreagents. The list of fluorescent (immuno)labels includes fluorescein isothiocyanate (FITC), tetramethylrhodamine isothiocyanate (TRITC), Texas Red, phycobiliproteins and the recently developed cyanine dyes such as the indopentamethinecyanines (CY5) $(40,85,124,140)$, of which the most frequently used is FITC. This because FITC can be excited at the $488 \mathrm{~nm}$ line of an argon laser, is easily conjugated to antibodies, lectins and other compounds, has a relatively high fluorescence, is water soluble, and has a long record of successful use (146). FITC antibodies have been applied for detection of Vibrio salmonicida (44), Salmonella spp. (24), Legionella spp. (141), Staphylococcus aureus (25), Streptococcus cremoris (46), Listeria monocytogenes (27), Escherichia coli 0157:H7 (106), and anaerobic fecal bacteria (143). Porro et al. (101) used FITC conjugated to the lectin 
concanavalinA for cell surface labelling of Saccharomyces cerevisiae. In general, disadvantages of FITC are its moderate photostability, and its $\mathrm{pH}$ dependent fluorescence which is significantly decreased at low $\mathrm{pH}$.

To date, the phycobiliproteins are the most powerful fluorescent labels. These proteins are a family of macromolecules found in red algae and cyanobacteria, and their natural function is absorption of light energy and its transfer to the photosynthetic pathway $(89,124)$. R-phycoerythrin (R-PE), for example, has an extremely high $\epsilon\left(1.96 \times 10^{5} \mathrm{~m}^{2}\right.$ $\mathrm{mol}^{-1}$ ), and a high $\Phi$ of 0.68 . (140). The phycobiliproteins are almost exclusively used as immunofluorescent labels for eucaryotic cells, in particular lymphocytes, although they have also been applied in microbiology. In the study by McClelland and Pinder (77), R-PE labelled Salmonella typhimurium was discriminated from FITC-labelled Salmonella enteridis or Salmonella montevideo by flow cytometry. Porter et al. (102) reported the recovery of Escherichia coli from sewage by R-PE labelled antirabbit IgG antibodies in an indirect immunoassay (i.e. the antigen of interest is recognized by a primary antibody, which in its turn is recognized by the (secondary) fluorescent conjugated antibody). General use of the phycobiliproteins is limited by the large size of the molecules $\left(M_{w} \approx 240000\right)$, which makes labelling of small molecules impossible or more difficult (124).

2. Nucleic acid probes. A large variety of fluorescent DNA/RNA probes are available, but it is beyond the scope of this review to discuss each with their possible applications. The reader is directed to a number of comprehensive reviews by Latt (63), Arndt-Jovin and Jovin (4), Ratinaud et al. (109), Shapiro (124), Petit et al. (96), and Haughland (40). The two most commonly used nucleic acid probes for enumeration of microorganisms are acridine orange (AO), and 4',6-diamidino-2-phenylindole (DAPI) (58). These probes, however, do not differentiate between viable and non-viable cells and are generally used in combination with fixatives such as formaldehyde and glutaraldehyde. In food microbiology the use of $A O$ in the direct epifluorescent filter technique (DEFT) is well documented, and was first described by Pettipher et al. (98) for the enumeration of bacteria in raw milk. The interaction of AO with DNA is complex and depends very much on the concentration of the dye and whether DNA is double or single stranded $(63,124)$. The absorption maximum of AO (bound to DNA) is at $490 \mathrm{~nm}$ (approx.) and the fluorescence around $520 \mathrm{~nm}$ (doublestranded DNA) or $>600 \mathrm{~nm}$ (single-stranded DNA). In 1980, Porter and Feig (104), and Coleman (19) were the first to describe the use of DAPI for counting (aquatic) bacteria. The advantage of DAPI over AO is the more intense fluorescence, which for example allowed detection of marine bacteria containing minute quantities (femtograms) of DNA (122). DAPI binds preferentially to the A-T base pairs. The absorption of DAPI bound to DNA is in the UV region ( $360 \mathrm{~nm}$ ) with fluorescence at $460 \mathrm{~nm}$, giving blue-coloured cells. DNA probes with similar properties are the bisbenzimidazoles (better known as Hoechst dyes). These Hoechst dyes are cell permeable and do not necessarily require a fixation treatment $(63,124)$. Hoechst 33285 and 33324 have been used for enumeration of 
Table 1. Spectroscopic properties of fluorescent probes used in microbiology".

\begin{tabular}{|c|c|c|c|c|c|}
\hline Probe $^{b}$ & $\begin{array}{l}\text { Extinction } \\
\text { coefficient } \\
\left(\mathrm{m}^{2} \mathrm{~mol}^{-1}\right)^{\mathrm{c}}\end{array}$ & $\begin{array}{l}\text { Quantum } \\
\text { yield }\end{array}$ & $\begin{array}{l}\text { Absorption } \\
\text { maximum } \\
\text { (nm) }\end{array}$ & $\begin{array}{l}\text { Emission } \\
\text { maximum } \\
(\mathrm{nm})\end{array}$ & $\begin{array}{l}\text { Measurement } \\
\text { conditions }\end{array}$ \\
\hline \multicolumn{6}{|l|}{ Immunoreagents } \\
\hline R-Phycoerythrin & $1.96 \times 10^{5}$ & 0.68 & 480,570 & 578 & pH 7, PBS \\
\hline FITC & 6700 & 0.71 & 490 & 520 & $\mathrm{pH} \mathrm{7,} \mathrm{PBS}$ \\
\hline \multicolumn{6}{|l|}{ Nucleic acid probes } \\
\hline Ethidium bromide & $300-600$ & -0 & 370,530 & 622 & + DNA \\
\hline Propidium iodide & 640 & 0.09 & 536 & 623 & $+\mathrm{H}_{2} \mathrm{O} / \mathrm{DNA}$ \\
\hline \multirow[t]{2}{*}{ Acridine orange } & 6500 & - & 480 & 520 & $+\mathrm{H}_{2} \mathrm{O} / \mathrm{ds}-\mathrm{DNA}^{e}$ \\
\hline & & & 450 & 640 & + ss-DNA \\
\hline DAPI & 2700 & - & 360 & 460 & $+\mathrm{H}_{2} \mathrm{O} / \mathrm{DNA}$ \\
\hline ToTo-1 & 11200 & 0.34 & 514 & 533 & + DNA \\
\hline PO-PRO-3 & - & - & 532 & 562 & $+\mathrm{H}_{2} \mathrm{O} / \mathrm{DNA}$ \\
\hline \multicolumn{6}{|c|}{ Physiological indicators } \\
\hline carboxyfluorescein & 8200 & - & 492 & 514 & pH 9 \\
\hline BCECF & 9400 & - & 505 & 530 & high $\mathrm{pH}$ \\
\hline Pyranine & 2100 & $>0.9$ & 454 & 513 & high pH \\
\hline Rhodamine 123 & 8500 & 0.9 & 511 & 534 & in ethanol \\
\hline CTF & & & 450 & $570-660 \mathrm{~g} t$ & crystals \\
\hline cSNARF-1 & 4490 & 0.09 & 575 & 637 & high pH \\
\hline cFSE & 6800 & - & 492 & 518 & pH 9 \\
\hline $\mathrm{DiOC}_{6}(3)$ & 15400 & 0.05 & 484 & 501 & in methanol \\
\hline $\operatorname{DiBAC}_{4}(3)$ & 12300 & - & 493 & 516 & in methanol \\
\hline $\operatorname{DiSC}_{3}(5)$ & 24000 & - & 651 & 675 & in methanol \\
\hline \multicolumn{6}{|l|}{ Enzyme products' } \\
\hline fluorescein & 9000 & 0.9 & 490 & 514 & pH 9 \\
\hline 4-MU & 1700 & - & 360 & 450 & $\mathrm{pH} 9$ \\
\hline
\end{tabular}

- data extracted from references $(40,109,124,133,140,146,148)$

b abbreviations: FITC, fluorescein isothiocyanate; DAPI, 4',6-diamidino-2-phenylindole; TOTO-1, 1,1'-(4,4,7,7tetramethyl-4,7-diazaundecamethylene)-bis-4-[3-methyl-2,3-dihydro-(benzo-1,3-thiazole)-2-methylidene]quinolinium tetraiodide); PO-PRO-3, 4-[3-methyl-2,3-dihydro-(benzo-1,3-oxazole)-2-methylidene]-1-(3'trimethylammoniumpropyl)-pyridinium diiodide ; BCECF, 2',7'-bis-(2-carboxyethyl)-5-(and-6)-carboxyfluorescein; CTF, 3-cyan-1,5-di-tolyl-formazan; Pyranine, 8-hydroxy-1,3,6-pyrene-trisulfonic acid; 4-MU, 7-hydroxy-4methylcoumarin; cSNARF-1, carboxy-seminaphtorhodafluor-1 or 5-(and 6-) carboxy-10-dimethylamino-3-hydroxyspiro[7H-benzo[c]xanthene-7, $1^{\prime}\left(3^{\prime} H\right)$-isobenzofuran]-3'-one; cFSE, 5-(and-6)-carboxyfluorescein succinimidyl ester; $\operatorname{DiOC}_{6}(3), 3,3$-dihexyloxacarbocyanine iodide; $\operatorname{DiBAC}_{4}$ (3), bis-(1,3-diburylbarbituric acid)trimethine oxonol. $\mathrm{DiS}_{3}(5) ; 3,3^{\prime}$-dipropylthiadicarbocyanine iodide. ' for expression in liter mol' $\mathrm{cm}^{-1}$ multiply values by $10 ;{ }^{\bullet} \cdot$, no data available; ' ss-DNA, single stranded DNA; ds-DNA, double-stranded DNA; ${ }^{\prime}$ the enzyme substrates are normally not fluorescent; " absorption maximum of CTF crystals has not been determined exactly. 


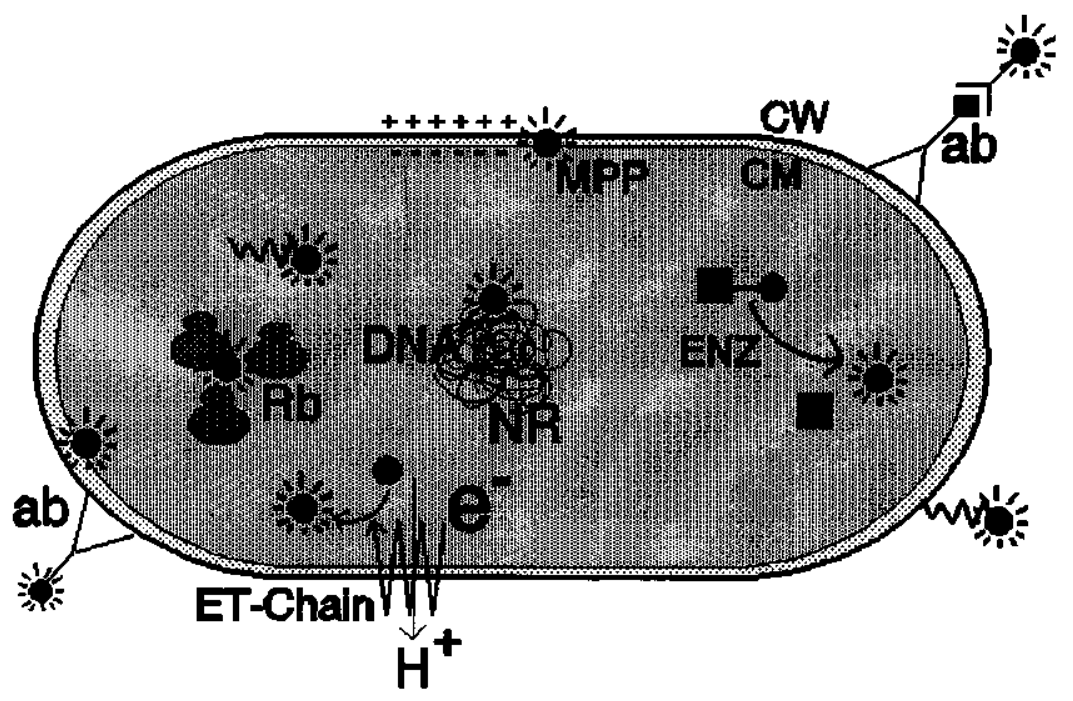

Fig. 2. Targets for fluorescence labelling of bacteria. *, fluorescent probe; $N N^{*}$, covalent binding of fluorescent probe; $\mathrm{CM}$, cytoplasmic membrane; $\mathrm{Rb}$, ribosomes; $\mathrm{NR}$, nuclear region; CW, cell wall; ET-Chain, electron transfer chain; ENZ, enzyme activity; D. , fluorescent precursor; $a b$, antibody; MPP, membrane potential probe

planktonic bacteria (92). The fluorescence of the phenanthridinium dyes ethidium bromide (EB) and propidium iodide (PI) is strongly enhanced upon intercalation between DNA or RNA base pairs. EB is well known for its use as DNA stain in gel electrophoresis. PI and to a lesser extent EB are excluded by intact cells, but do stain permeable cells. This principle can potentially be used to assess cell viability and is discussed in more depth later. EB and PI have relatively low extinction coefficients, which complicates their use in cells with small quantities of DNA and RNA, such as prokaryotes. Significantly, it has been described that PI may stain cell walls of yeast cells, conceivably by interaction of PI with chitin (54). Steen et al. (132), and Allman et al. (2) used a combination of EB and mithramycin for determination of bacterial DNA content. Mithramycin stains the GC-rich region of DNA, and its optimal excitation energy is around $430 \mathrm{~nm}$. EB is used to enhance 


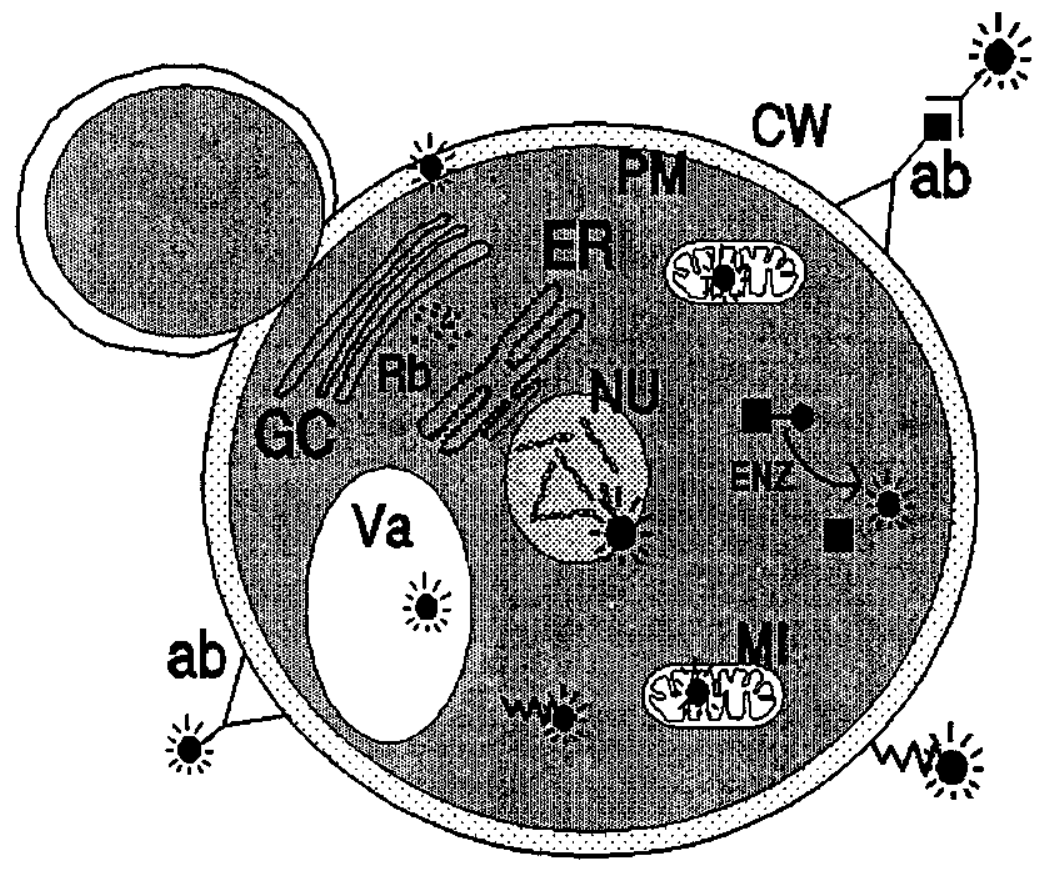

Fig. 3. Targets for fluorescent labelling of yeasts. $*$, fluorescent probe; $M M^{*}$, covalent binding of fluorescent probe; PM, plasma membrane; Rb, ribosomes; $\mathrm{NU}$, nucleus; $\mathrm{CW}$, cell wall; Mi; Mitochondrion; Va, Vacuole, ER, endoplasmic reticulum; GC, golgi complex; ENZ, enzyme activity; $1-0$, fluorescent precursor; ab, antibody. 
the fluorescence by resonance energy transfer. The DNA specific emission energy of mithramycin is absorbed by the EB molecules which are close enough for energy transfer to occur. Fluorescence from RNA-bound EB is negligible when using this method. Significantly, active extrusion systems for EB have been described in several bacteria including L. lactis (6), B. subtilis (86), E. coli (80), and Staphylococcus aureus (120) which may interfere with the intracellular DNA labelling of the cells.

Recently, a group of pyridinium and quinolinium dyes have been synthesized by Molecular Probes (40), which have very high extinction coefficients, a high affinity for DNA and RNA and a high photostability $(40,136)$. These probes have molecular weights in the range of 600 to 1300 dalton, and are excluded by intact cells. Chapter 6 (this thesis) describes the effective use of the benzothiazolium-4-quinolinium dimer TOTO-1 to demonstrate the permeabilization of Lactococcus lactis by detergents.

3. Physiological indicators. This is a rather wide group which includes dyes for analysis of intracellular $\mathrm{pH}\left(\mathrm{pH}_{\mathrm{in}}\right)$, membrane potential, reducing activity and intracellular calcium concentration. More general information can be found in the reviews and books by Haughland (39), Shapiro (124), Tsien (139), and Manafi et al. (69).

The fluorescent probes that are applied to determine the $\mathrm{pH}_{\mathrm{in}}$ in microorganisms include carboxyfluorescein [cF] (48), 2',7'-bis-(2-carboxyethyl)-5-(and-6)-carboxyfluorescein [BCECF] (81), 5-(and 6-) carboxy-10-dimethylamino-3-hydroxy-spiro[7H-benzo[c]xanthene$7,1^{\prime}\left(3^{\prime} H\right)$-isobenzofuran]-3'-one [cSNARF-1] (42), and Pyranine (95). All these dyes have $\mathrm{pH}$ sensitive fluorescence spectra. In microorganisms, however, the application of fluorescent probes is generally limited by either inefficient uptake of the probes by the cells or, following uptake, leakage of probe from the cells. This results in a decreased cell-associated signal in combination with increased background signal. Currently, the most commonly used probe is BCECF. This derivative of fluorescein has a $\mathrm{pK}_{\mathrm{a}}$ of 6.97 and four to five negative charges at physiological $\mathrm{pH}$, which enhances intracellular retention compared to fluorescein or CF $(39,110)$. In our laboratory, BCECF was efficiently taken up by Saccharomyces cerevisiae, $L$. lactis and Lactobacillus plantarum, following incubation of cells with its non-fluorescent acetoxymethyl ester BCECF-AM (12). The ester form is membrane permeable and cleaved in the cytoplasm by esterases to liberate BCECF. Other authors, however, have reported insufficient accumulation of BCECF in both bacteria (81) and in yeasts (42). The reason for this is not well understood, but it was speculated that it resulted from insufficient esterase activity and/or inadequate uptake of BCECF-AM. In $E$. coli a short incubation with EDTA resulted in improved uptake of BCECF-AM (12). Moreover, BCECF, fluorescein and $\mathrm{cF}$ may be actively extruded from cells by transport systems $(1,9,82)$.

A relatively new probe with excellent absorbance and emission spectra for determination of the (intracellular) pH, is cSNARF-1 $(40,148)$. Haworth and co-workers $(41,42)$ were the first to apply this probe for determination of $\mathrm{pH}_{\text {in }}$ in yeasts. The principal advantage of 
CSNARF-1 over BCECF in these studies was the superior incorporation of this probe, although the incubation time for uptake was relatively long (approx. 3 hours). A possible disadvantage with this probe is that excitation at $488 \mathrm{~nm}$ and $514 \mathrm{~nm}$ (argon-ion laser), although possible, is not optimal for maximum emission. CSNARF-1 could be incorporated into the cells as its acetoxymethyl ester (cSNARF-1-AM). Moreover, the $\mathrm{pK}_{\mathrm{a}}$ of cSNARF-1 is between 7.4 and 7.6 (depending on the excitation and emission wavelengths), which is rather high. This can create problems for measurement of the $\mathrm{pH}_{\text {in }}$ of acidophilic microorganisms (108).

Recently, a novel method for determination of $\mathrm{pH}_{\mathrm{in}}$ in bacteria was developed which was based on the intracellular conjugation of the fluorescein derivative 5-(and-6)-carboxyfluorescein succinimidyl ester (cFSE) (11). This cFSE method significantly reduced problems due to efflux of the fluorescent probe during the measurement. It has been successfully applied to determine the $\mathrm{pH}_{\text {in }}$ in Lactococcus lactis, Bacillus subtilis, Listeria innocua and Escherichia coli.

The membrane potential in cells can be determined by the distribution of lipophilic ionic molecules between the cells and the suspending medium according to the Nernst equation $(31,38,71,125)$ :

$$
\Delta \Psi=-\frac{R T}{n F} \ln \frac{[X]_{i}}{[X]_{o}}
$$

where $\Delta \Psi$ is the membrane potential (in Volt), $R$ is the gas constant (in $\mathrm{J} \mathrm{K}^{-1}$ ), $n$ is the number of electrons per mole, $F$ is the Faraday constant (in $\mathrm{C} \mathrm{mol}^{-1}$ ), $T$ is temperature (in degrees Kelvin), $[X]_{\mathrm{i}}$ is the concentration of the indicator inside the cell (in $\mathrm{mol} \mathrm{m} \mathrm{m}^{-3}$ ), and $[X]_{0}$ is the concentration outside the cell (in $\mathrm{mol} \mathrm{m}^{-3}$ ). The properties of the ideal membrane potential probe are discussed by Lolkema (66) and summarized here: (i) the probe should pass rapidly the membrane, (ii) it should not bind to the membrane or other constituents, (iii) it should be detectable at very low concentrations, and (iv) it should be biologically inert. Distributional fluorescent probes applied in microbiology are Rhodamine 123, positively charged carbocyanines such as 3,3-dihexyloxacarbocyanine iodide $\left(\mathrm{DiOC}_{6}(3)\right)$, 3,3-diethyloxacarbocyanine iodide $\left(\operatorname{DiOC}_{2}(3)\right)$, and 3,3'-dipropylthiadicarbocyanine iodide $\left(\mathrm{DiS}_{3}(5)\right.$, and the negatively charged bis-(1,3-dibutylbarbituric acid)trimethine oxonol $\left(\operatorname{DiBAC}_{4}(3)\right)(23,51,55,71,72,73,83,94,97,142,145,154)$. Rhodamine 123, $\operatorname{DiOC}_{6}(3)$ and DiBAC $_{4}(3)$ can all be excited by the $488 \mathrm{~nm}$ line and emit green fluorescence. Cells which have a membrane potential (negative inside) accumulate the cationic rhodamine 123 and also cyanines, whereas oxonols are excluded. Significantly, in eucaryotic cells rhodamine 123 accumulates preferentially in the mitochondria, due to the high membrane potential present in this organelle $(26,113)$. Less hydrophobic cyanines are also expected to accumu- 
late into mitochondria $(94,97)$. However, a high intramitochondrial carboxycyanine concentration may well be toxic to the cells, and the fluorescence is likely to be quenched $(94,125)$. In 1984, Matsuyama (76) was the first to demonstrate that also bacteria could be stained by Rhodamine 123 . Problems associated with lipophilic membrane potential probes are the potentially strong binding to cell constituents such as membranes, and formation of non-fluorescent aggregates at higher concentrations $(31,38,125)$. To avoid these problems, Krasznai et al. (62) developed a calibration procedure based on the assumption that there exists a direct relation between the total cell-related fluorescence and the free intracellular dye concentration, which is in (nernstian) equilibrium with the extracellular fluorescence. Using this procedure, the membrane potential in rat thymocytes and human lymphocytes could be measured with the oxonol $\operatorname{DiBAC}_{4}(3)$. The obtained results were in good agreement with those by the patch clamp method. Significantly, in mammalian cells active efflux systems are described which impaired accumulation of lipophilic dyes including Rhodamine 123, cyanines and a bis-oxonol (59). At the moment, it is becoming more and more apparent that such systems exist also in bacteria, and may thus interfere with membrane potential assays (6).

In 1984, Stellmach (133) described the synthesis of the non-fluorescent redox dye 5cyano-2,3-ditolyl tetrazolium chloride (CTC). In his study CTC was used as an alternative electron acceptor to prove the existence of redox enzymes in Ehrlich Ascites tumor cells. Rodriquez et al.(111) demonstrated in 1992 that respiring bacterial cells can reduce CTC to the red fluorescent, water-insoluble formazan product 3-cyan-1,5-di-tolyl-formazan (CTF). CTF has an absorption peak at $450 \mathrm{~nm}$, and the fluorescence of the crystals is in the red region (approx. $570-650 \mathrm{~nm}$ ), whereas solubilized formazan is non-fluorescent (133).

4. Enzyme substrates. The general concept for detection of enzyme activities by fluorescent probes is (enzymatic) conversion of a non-fluorescent (fluorogenic) substrate to the fluorescent product. The substrates are most commonly derived from such fluorescent probes as fluorescein and coumarin, in particular 7-hydroxy-4-methylcoumarin (4-methylumbelliferyl or 4-MU) $(40,69)$. Some examples are glucuronidase substrates such as 4-MU$\beta$-D-glucuronide, esterase substrates such as fluorescein diacetate (FDA), $\beta$-galactosidase substrates such as carboxyfluorescein digalactoside, and substrates such as dihydrofluorescein diacetate, which is first converted by esterases to the nonfluorescent dihydrofluorescein (fluorescin) and then by peroxidases to fluorescein $(40,69,146)$. Exploitation of these substrates in microbiology include detection of $E$. coli by its $\beta$-glucuronidase activity (69), detection of LacZ-positive cells by $\beta$-galactosidase activity $(40,88)$, and detection of viable (i.e. esterase containing) cells by the non-specific hydrolysis of fluorescein diacetate. In the latter example, various uncharacterized esterases are involved (as discussed in chapter 2 of this thesis).

5. Miscellaneous. Some examples of this group are membrane probes and fluorescently labelled hormone receptors. Fluorescent membrane probes include fluorescently labelled 
phospholipids (such as pyrenedecanoyl phosphocholine), fluorescently labelled fatty acids (such as acylaminofluorescein), 1-anilinonaphthalene-8-sulfonic acid, lipophilic carbocyanines, 1,6 diphenyl-1,3,5-hexatriene (DPH) and its analog 1-(4-trimethylammoniumphenyl)-6-phenyl-1,3,5-hexatriene (TMA-DPH), and many others $(40,146)$. In general, these probes are used only occasionally in microbiology. Exceptions are DPH and TMADPH which have been used to determine the membrane fluidity in various bacteria by measuring the anisotropy of the probes $(49,126)$. The polarization of these probes depends on the rotational mobility in the membrane.

\section{Flow cytometry}

Flow cytometry (FCM) is the measurement of physical and/or chemical characteristics of (biological) particles while passing in a fluid stream through a measuring apparatus (124). The parameters measured by a standard flow cytometer are fluorescence and light scattering, which is very schematically shown in Fig. 4. A flow cytometer essentially consists of three systems which will be briefly discussed:

1. The fluidic system. The fluidic system is comprised of a sample stream surrounded by a sheath fluid. The relative velocities of both flow streams are adjusted, such that cells pass one by one in a laminar flow past the measuring point. Generally, a flow cytometer can measure up to $10^{4} \mathrm{cells} / \mathrm{s}$, although normally they are set at lower cell passage rates. The exposure time of the cells to the excitation beam can be calculated from the flow rate and the beam geometry. For example when cells with a flow rate of $6 \mathrm{~m} \mathrm{sec}^{-1}$ pass an elliptical beam with dimensions of $20 \times 64 \mu \mathrm{m}$, the exposure time to the excitation beam will be 10 $\mu$ s (approx.). The main advantage of the short exposure time is that photofading (photodamaging) is generally not a problem in FCM.

2. The optical system. The optical system essentially consists of an excitation source, optical filters and a detector, which is most commonly a photomultiplier (PMT). Common excitation sources are a mercury arc lamp or an argon ion laser, which emits at a variety of wavelengths including the frequently used $488 \mathrm{~nm}$ and $515 \mathrm{~nm}$ line. The excitation and emission wavelengths are selected by optical filters depending on the application. Light scattering can be measured at right angles (side scatter), or low angles (forward scatter). Generally, the forward scatter is used as an indication of particle size and the side scatter as indication of granularity. Finally, the PMTs convert the optical signals into electrical signals. A flow cytometer is normally equipped with a PMT with good responses in the UV and green region, and a PMT with a good response in the red region. 


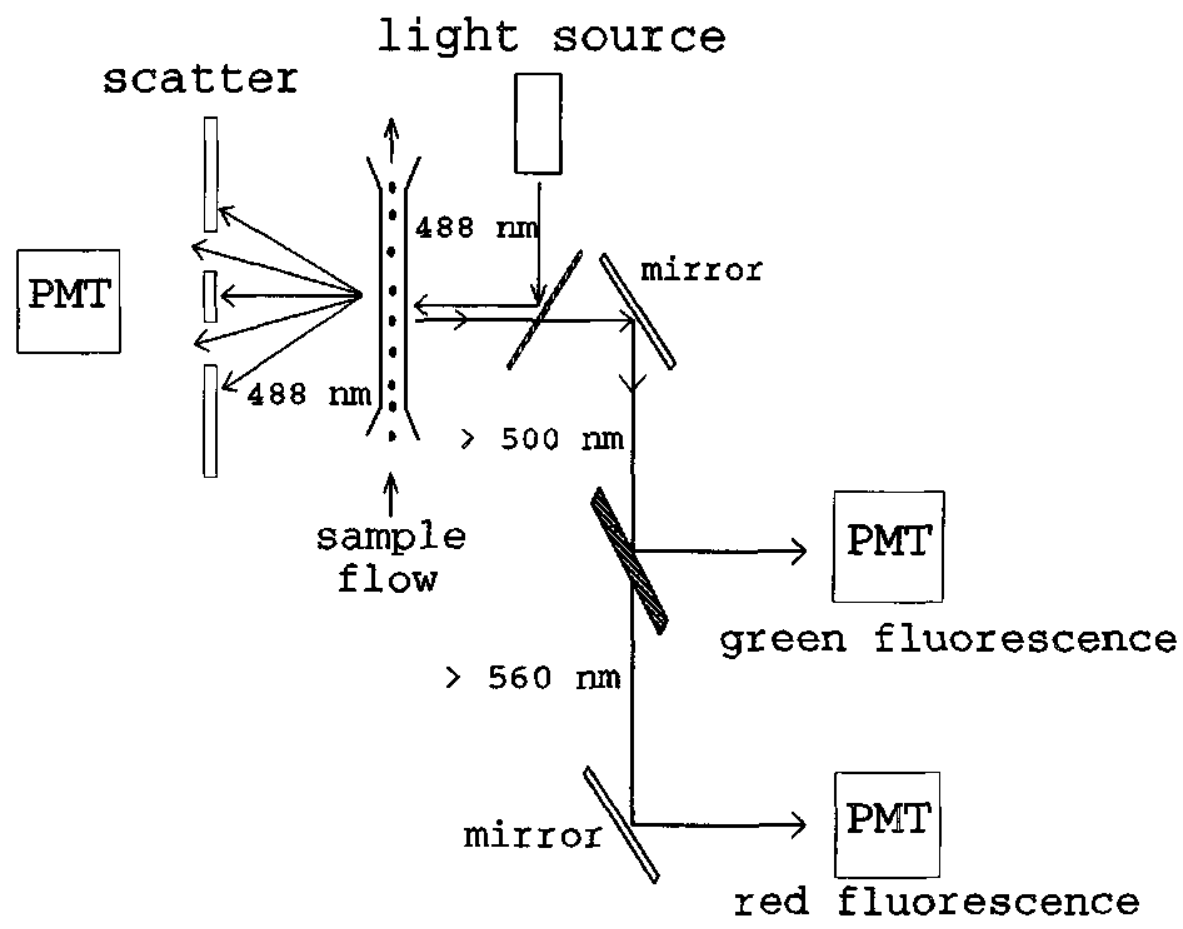

Fig. 4. Schematic representation of a typical flow cytometer. The sample flow is illuminated by the incident light beam and the passing particles will absorb and scatter this light. By use of optical filters the scattered light, green fluorescence and red fluorescence emission are simultaneously detected by photomultipliers. PMTs then convert these signals into electrical signals, which allows data processing. 
3. The electronic system. The electrical signals which are received from the PMT are normally represented in a histogram where the $y$-axis represents the number of fluorescent particles and the $\mathrm{x}$-axis is divided into "channels" (most commonly 256) relative to the fluorescence intensity of the signals. At present, the majority of flow cytometers have a built-in logarithmic amplifier. This device produces an output signal proportional to the logarithm of the input signal. In this way a wider range of signals can be measured in one histogram.

The ultimate strength of FCM is that it can analyze multiple parameters (scatter, green fluorescence, red fluorescence) of a high number of cells, in a very short time. Moreover, many flow cytometers have the capability to sort cells with particular characteristics, which makes this technique very powerful for detection and isolation of rare events. The most obvious disadvantage of FCM is the incapability to analyze the same cells over a longer time period. Moreover, the microorganisms need to be suspended in a fluid medium. Although FCM for analysis of mammalian cells has found wide application, the use of FCM in microbiology is still relatively limited. This is essentially because of the small size of most microorganisms. Nevertheless, various applications of FCM in microbiology exist $(2,32,71,99,103)$, which range from DNA analysis of marine bacteria to determination of the membrane potential in bacteria such as Staphylococcus aureus and E. coli. For extensive information about FCM the reader is directed to the excellent book by Shapiro (124).

\section{Viability assessment of microorganisms.}

As mentioned in the introductory paragraph, viability can be defined as the capability of performing all cell functions necessary for survival under given conditions. The elementary requirements for viable microorganisms to survive are: (i) an intact cytoplasmic (plasma) membrane which functions as a barrier between the cytoplasm and the extracellular environment, (ii) DNA transcription, and RNA translation, (iii) generation of energy for maintenance of cell metabolism, biosynthesis of proteins, nucleic acids, polysaccharides, and other cell components, and, eventually, (iv) growth and multiplication. Methods for assessment of cell viability are based on these requirements, and summarized in Table 2 . In the following section various rapid methods will be discussed with particular emphasis on their application in microbiology.

(i) Membrane integrity. The use of biological stains such as methylene blue and Congo red for determination of cell viability dates to the beginning of this century (116). These dyes are exploited to determine the integrity of the cytoplasmic membrane. The general principle is that viable cells which have intact membranes are not stained. In cells with 
compromised membranes (non-viable cells) the dyes can enter, which results in staining of the cells. The use of DNA probes such as PI for assessment of viability is based on the same principle. Gant et al. (33) applied PI to analyse the response of $E$. coli to various antibiotics such as gentamycin, ampicillin, ciprofloxacin, etc. Humphreys et al. (47) used PI to stain dead cells of Trichomonas vaginalis. Whether or not the criterion of membrane integrity (permeability) is a reliable indicator of viability is a matter of controversy. Jepras et al. (51) demonstrated that a significant percentage of heat killed $E$. coli cells was poorly stained by propidium iodide, and López-Amorós et al. (67) concluded that the cytoplasmic membrane remained intact in starved, non-culturable $E$. coli and Salmonella typhimurium cells, since they were not stained by PI. On the other hand, Votyakova et al. (145) showed

Table 2. Methods for the assessment of viability of microorganisms.

\begin{tabular}{llll} 
criterion & method & time & comments \\
\hline reproduction & plate count method & $2-5$ days & high sensitivity \\
membrane integrity & $\begin{array}{l}\text { methylene blue } \\
\text { staining, influx } \\
\text { DNA probes }\end{array}$ & $30 \mathrm{~min}$ & $\begin{array}{l}\text { dye exclusion tests, i.e. viable cells will } \\
\text { not be stained }\end{array}$ \\
$\begin{array}{l}\text { cell morphology } \\
\text { (cell elongation) }\end{array}$ & $\begin{array}{l}\text { inhibition of cell } \\
\text { division by nalidixic acid } \\
\text { or other antibiotics }\end{array}$ & $\begin{array}{l}\text { only for antibiotic sensitive bacteria, } \\
\text { microscopical analysis elongated cells. }\end{array}$ \\
respiration & $\begin{array}{l}\text { reduction tetra- } \\
\text { zolium dyes }\end{array}$ & $1-4 \mathrm{~h}$ & $\begin{array}{l}\text { accumulation of insoluble formazan } \\
\text { products. }\end{array}$ \\
enzyme activity & $\begin{array}{l}\text { Fluorescein diacetate } \\
\text { method (esterase act.) }\end{array}$ & fluorescein is accumulated in intact cells \\
membrane potential & $\begin{array}{l}\text { Rhodamine 123, } 1 \mathrm{~h} \\
\text { carboxycyanine dyes, oxonols } \\
\text { (negative inside) }\end{array}$ & $\begin{array}{l}\text { potential dependent distribution of dye } \\
\text { between cells and extracellular medium }\end{array}$ \\
pH gradient & $\begin{array}{l}\text { intracellular pH } \\
\text { measurement }\end{array}$ & viable cells maintain pH gradient \\
presence of ATP & ATP determination $10 \mathrm{~min}$ & low sensitivity, indirect method \\
\hline
\end{tabular}


that starved Micrococcus luteus cells were stained with the (impermeable) DNA probe 4-[3methyl-2,3-dihydro-(benzo-1,3-oxazole)-2-methylidene]-1-(3'-trimethylammoniumpropyl)pyridinium diiodide (PO-PRO-3, molecular weight 605), suggesting that these cells were not viable. Significantly, however, more than $50 \%$ of these cells could no longer be stained by PO-PRO-3 after resuscitation for 1 day, which apparently allowed recovery of the cells.

(ii) Changes in cell morphology. The application of the 4-quinolone antibiotic nalidixic acid (1-ethyl-1,4-dihydro-7-methyl-4-oxo-1,8-naphthyridine-3-carboxylic acid) for determination of cell viability was proposed by Kogure et al. in 1979 (61). Nalidixic acid, the synthesis of which was reported by Lesher et al (64) in 1962, inhibits DNA replication in most gram-negative bacteria, thereby preventing cell division $(35,36)$. Other cell functions, however, continue to function normally, given that the nalidixic acid concentration is not too high. Consequently, viable cells will be elongated and can be recognized and counted by microscopy. The addition of nutrients, usually a small amount of yeast extract, is generally required (61). This direct viable count (DVC) method has been applied for detection of viable Vibrio vulnificus $(91,105)$, estimation of viable counts of several gramnegative bacteria in an aquatic environment $(15,20,28,29,112,115,127,128,129,150)$, and detection of viable bacteria in biofilms $(151,152)$. In general, viable counts determined by the DVC method are considerably higher than the corresponding plate counts, which implies the existence of viable but nonculturable bacteria. Rollins and Colwell (112) used the DVC method to investigate the survival of a Campylobacter jejuni strain (originally isolated from a human campylobacteriosis patient) in filter sterilized water. At $37^{\circ} \mathrm{C}$ a rapid transition occurred from the spiral form to the coccoid form accompanied by a decrease of the plate count. The DVC method, however, indicated that the majority of the nonculturable coccoid cells were still viable. On the other hand, in a recent study by Hazeleger et al. (43) it was demonstrated that coccoid Campylobacter jejuni cells formed at low temperatures $\left(4^{\circ} \mathrm{C}\right)$ retained several properties of spiral cells for a long time, while those formed at higher temperatures $\left(25^{\circ} \mathrm{C}\right)$ show degeneration, and are apparently not viable. Pryer and Oliver (105) indicated that in psychrophilic marine Vibrio strain, the DVC method may not be reliable because during the stationary phase viable bacteria (as determined by plate count) did not respond to the nalidixic acid treatment. The DVC method has several practical problems. Elongation of the cells is most commonly judged by eye, and the criterium to score cells positive is quite arbitrary. Moreover, the effective concentration of the antibiotic depends on the bacterial species, and the minimal incubation time required to obtain elongated cells is critical. Some of these constraints may be circumvented by use of image analysis techniques, which allows quantitative and objective analysis of cell sizes $(127,128)$. Obviously, the DVC method is limited to nalidixic acid-sensitive bacteria. Buchrieser and Kaspar (14), therefore, tested several other antibiotics with a similar mode of action as nalidixic acid for the enumeration of bacteria in milk. They found strong 
elongation of a range of bacteria induced by the antibiotics ciprofloxacin and mitomycin $\mathbf{C}$. However, in a recent study by Servis et al. (123) ciprofloxacin, and other antibiotics such as enoxacin, norfloxacin, and isopropyl cinodine were not very effective, i.e. the maximum percentage of enlarged cells of various gram-positive bacteria in the presence of antibiotic was always less than $40 \%$.

(iii) Enzyme activity. In 1966, Rotman and Papermaster (117) reported the use of fluorescein diacetate (FDA), a non-fluorescent precursor (prefluorochrome), which is taken up by mammalian cells and cleaved by intracellular enzymes to give the fluorescent product fluorescein. The staining by FDA is based on the assumption that only cells which have an intact membrane and esterase activity are able to accumulate the fluorescent probe. This concept has been applied for the determination of viable fungi in soil $(120,131)$, viable bacteria in fresh water (17) and soil (68), Mycobacteria (50), viability of Trichomonas vaginalis (47), and yeasts spores (21). Counterstaining with PI (to stain permeabilized cells) is frequently applied $(52,47,121)$. The FDA method is, however, easily frustrated due to efflux of fluorescent probe to the external environment, which results in a decreased signal to noise ratio (10). Leakage of probe to the external environment may be minimized by application of fluorescein derivatives such as carboxyfluorescein, calcein and BCECF, which are more negatively charged at physiological $\mathrm{pH}$, and are thus less likely to leak from the cells. The relation of the FDA method with viability is based on both membrane integrity and esterase activity. As discussed earlier, the criterion of membrane integrity is controversial, and also the relationship of esterase activity with viability is disputable. Previous results indicated that carboxyfluorescein was accumulated in heat killed $S$. cerevisiae cells (9), and it has been demonstrated that erythroleucemic cells, killed by the pesticide tributyltin, exhibited higher, instead of decreased fluorescence (74). Furthermore, fluorescein, $\mathrm{cF}$ and BCECF may be extruded by energy-dependent efflux systems, which have been found in various bacteria and yeasts $(9,12,82)$. The strength of the FDA method is the speed and high, thus readily detectable, fluorescence of stained cells.

(iv) Respiration. Respiring cells can reduce tetrazolium dyes to their respective formazan products. The dyes compete with oxygen as electron acceptor $(3,155)$. One of the most commonly used tetrazolium dyes is 2-(p-iodophenyl)-3-p-nitrophenyl)-5-phenyltetrazolium chloride (INT). INT has been used for assessment of respiring bacteria in aquatic (34,60, $87,90,107,135,155)$, and other environments $(30,37,78)$. In general, cells are examined microscopically for intracellular formazan deposits, or the formazan is extracted from the cells by e.g. ethanol, and quantified spectrophotometrically. The tetrazolium dye CTC has the unique advantage that the formazan product is fluorescent, which enormously enhances the sensitivity of the detection. CTC has been used to determine the number of respiring Micrococcus luteus, Listeria monocytogenes and Pseudomonas fluorescens in pure cultures $(8,53,56,57)$, and respiring bacteria in water $(18,106,111,119,129)$, soil $(149)$, and biofilms $(22,45,134,152,153)$. Walsh et al. (147) observed reduction of INT and CTC in an 
anaerobic culture of a thermophilic sulphate reducing bacteria. Recently, a new tetrazolium dye, $\quad 3^{\prime}-\{1-[($ phenylamino)-carbonyl]-3,4-tetrazolium $\}$-bis(4-methoxy-6-nitro)benzene sulfonic acid hydrate (XTT) was synthesized, which has the special property that the formazan product is water-soluble (93). XTT was applied by Roslev and King (114) for determination of viable respiring bacteria, and by Tellier (137) for testing the susceptibility of yeast to various antibiotics, in colorimetric assays based on reduction of XTT. The procedure commonly used for tetrazolium reduction assays is incubation of the cells (20 min to several hours) in the presence of the tetrazolium dye followed by fixation by formaldehyde, paraformaldehyde or formalin, and mounting with paraffin oil or immersion oil on a microscope slide for examination. Counterstaining with DAPI for determination of the total count is commonly performed $(8,45,53,111,152,134)$. Fixation and mounting is, of course, not necessary when the cells are measured by FCM (56). Formazan deposition may be enhanced by the addition of substrates such as succinate, glucose, and intermediate electron carriers such as phenazine methasulfate $(37,130,138,144)$. On the other hand, tetrazolium reduction may be reduced by phosphate, at concentrations above $10 \mathrm{mM}(130)$. Depending on the lipophilicity, some formazan products can diffuse out of the cells and form extracellular deposits. This could, in some cases, be suppressed by addition of cobalt ions, which supposedly form a complex with the formazan (138). The optimal initial concentrations found for CTC and INT were 4-5 mM and $2 \mathrm{mM}$, respectively $(56,111)$. With respect to this, Kaprelyants and Kell (56) suggested that the formazan product does inhibit cell respiration at higher concentrations. The relationship of formazan deposition (respiration, reducing activity) with viability is not clear-cut. Cells that reduce tetrazolium dyes are considered viable, but cells which fail to do so are not necessarily non-viable (5).

(v) membrane potential. In general, the cytoplasmic membrane potential of microorganisms is determined by the nernstian distribution of small lipophilic charged molecules, such as tetraphenylphosphonium $\left(\mathrm{TPP}^{+}\right)$ions $(66,71)$, and the earlier mentioned fluorescent probes. In $S$. cerevisiae a good correlation was found between the specific accumulation of Rhodamine 123 in mitochondria, determined by FCM, and the respiratory activity of the cells $(26,100)$. Kaprelyants and Kell (55) showed that by use of FCM, Micrococcus luteus cells could be divided in viable, non-viable, and non-viable but resuscitable cell populations. McFeters and co-workers used rhodamine 123 to assess the physiological activity of bacteria in biofilms $(79,152,153)$. They compared the rhodamine assay with the DVC (nalidixic acid) method, CTC reduction, RNA turnover, and plate count method. The plate count method gave a significant higher reduction of the viable count (approx. 1 log lower) than the other techniques, indicating that culturability is perhaps not very accurate for the assessment of disinfection efficacy (79). Morgan et al. (84) observed that Aeromonas salmonicida cells, starved in sterile lake water, became rapidly nonculturable, but could still accumulate Rhodamine 123. Recently, the use of the oxonol $\mathrm{DiBAC}_{4}$ has been described for determination of membrane potential in $S$. cerevisae (26), and in bacteria such as Staphylo- 
coccus aureus, Pseudomonas aeruginosa, E. coli, and Salmonella typhimurium $(23,51,67)$. In contrast to Rhodamine 123, DiBAC 4 is accumulated in cells with dissipated membrane potentials. The apparent advantage of $\mathrm{DiBAC}_{4}$ is its simpler application, and prevention of compartmentation (in mitochondria) in viable eucaryotic cells including yeast $(26,51,71)$, $\mathrm{DiBAC}_{4}$ has been applied to assess the effect of heat treatment, ionophores, and several antibiotics on the membrane potential of various bacteria $(23,47,72)$. The cytoplasmic membrane potential of bacteria is closely coupled to the energy metabolism of the cell (55). However, it is unclear whether or not cells without a membrane potential are necessarily non-viable. Moreover, in several gram-negative bacteria the addition of EDTA or EGTA (to permeabilize the outer membrane) is necessary to allow proper distribution of the membrane potential probes $(67,76)$. Obviously, such treatments may influence cell viability. (vi) $\mathrm{pH}$ gradient. The maintenance of a $\mathrm{pH}$ gradient in microorganisms at conditions where the external $\mathrm{pH}$ is suboptimal, can potentially be used as an indication of viability. This approach is, however, generally hampered by the difficulties in measuring the $\mathrm{pH}_{\text {in }}$ of individual microorganisms, especially bacteria. Recently, a relationship was observed between the ability to reproduce and the $\mathrm{pH}_{\text {in }}$ in Saccharomyces cerevisiae using fluorescence staining in combination with image analysis techniques (48). The advantage of such a system is that the cells can be analyzed individually.

\section{Outline of this thesis}

The objective of the present investigation is the development of rapid methods for the assessment of viability of microorganisms by fluorescence techniques. This $\mathrm{PhD}$ project will focus on two different techniques: (i) extrusion of fluorescent probes via energydependent efflux systems, and (ii) determination of intracellular $\mathrm{pH}$ exploiting $\mathrm{pH}$-dependent (covalently-bound) fluorescent probes. In general, microorganisms are fluorescently labelled by the conversion of non-fluorescent prefluorochromes by intracellular enzymes to fluorescent probes. For detection of fluorescence, various techniques were used including fluorescence microscopy, spectroscopy, and flow cytometry.

Chapter 2 describes the kinetics of fluorescein and $\mathrm{cF}$ accumulation in $S$. cerevisiae. Whether this accumulation is transport limited or enzyme-reaction limited is discussed in detail. A mathematical model is developed to describe the influence of uptake, hydrolysis, and efflux on the fluorescence staining, and the conditions for optimal staining of yeast cells with fluorescein diacetate and carboxyfluorescein diacetate are examined.

In Chapter 3 the emphasis is on the efflux of cF from $S$. cerevisiae. Evidence is provided that $S$. cerevisiae extrudes $\mathrm{cF}$ in an energy-dependent manner most likely via a 
secondary transport system. The efflux of $\mathrm{cF}$ from the cells is analyzed by FCM. The implications of the accumulation and efflux of $\mathrm{cF}$ for detection of yeasts and the rapid assessment of yeast viability and vitality by use of FCM are discussed.

The intracellular $\mathrm{pH}\left(\mathrm{pH}_{\text {in }}\right)$ is critical for the control of many cellular processes, such as DNA transcription, protein synthesis and enzyme activities. Chapter 4 describes a novel technique for measuring the intracellular $\mathrm{pH}$ of bacteria, based on the intracellular conjugation of carboxyfluorescein succinimidyl ester (cFSE). It thus offers the possibility to investigate the important physiological response of $\mathrm{pH}_{\mathrm{in}}$ variations in bacteria, even under severe stress conditions such as elevated temperatures, and exposure to detergents.

In Chapter 5 the viability of $R$. oligosporus sporangiospores and the mechanism of action of nonanoic acid, a self-inhibitor produced by various fungi, were investigated.

Evidence is presented that swelling and germination of $R$. oligosporus sporangiospores are associated with a $\mathrm{pH}_{\mathrm{in}}$ increase, and that inhibition of germination by nonanoic acid is mediated by the capacity of this substance to dissipate the $\mathrm{pH}$ gradient. A model is presented which describes the germination of sporangiospores.

Chapter 6 describes the effect of detergents on the viability of gram-positive bacteria. Growth, intracellular ATP concentrations, $\mathrm{pH}_{\mathrm{in}}$, cytoplasmic membrane integrity, and other metabolic parameters were determined to investigate the effect of Triton X-100 and $N$-dodecyl- $N, N$-dimethyl-3-ammoniopropane sulfonate (zwitterion SB 3-12) on L. lactis and Bacillus subtilis.

In the general discussion (Chapter 7) the significance of the energy-dependent efflux of $\mathrm{cF}$, and $\mathrm{pH}_{\mathrm{in}}$ for viability assessment of microorganisms is reviewed. In combination with FCM, which provides cell by cell analysis, fluorescence techniques allow a rapid and detailed analysis of the number of viable cells in a population. Perspectives for the application of such techniques in monitoring various industrial fermentation processes will be discussed

\section{References}

1. Allen, C.N., E.S. Harpur, T.J.B. Gray, N.L. Simmons, and B.H. Hirst. 1990. Efflux of bis-carboxyethylcarboxyfluorescein (BCECF) by a novel ATP-dependent transport mechanism in epithelial cells. Biochem. Biophys. Res. Commun. 172:262-267.

2. Allman, R., R. Manchee, and D. Lloyd. 1993. Flow cytometric analysis of heterogeneous bacterial populations, p. 27-47. In D. Lloyd (ed.), Flow Cytometry in Microbiology, Springer-Verlag, London, UK.

3. Altman, F.P. 1976. Tetrazolium salts and formazans. Progress Histochem. Cytochem. 9:1-56.

4. Arndt-Jovin, D.J., and T.M. Jovin. 1989. Fluorescence labeling and microscopy of DNA. p. 417-448. In D. Lansing Taylor and Y. Wang, (ed.),Methods in Cell Biology, Vol.30. Academic Press, Inc., London, UK.

5. Barer, M.R., L.T. Gribbon, C.R. Harwood, and C.E. Nwoguh. 1993. The viable but non-culturable hypothesis and medical bacteriology. Rev. Medic. Microbiol. 4:183-191. 
6. Bolhuis, H., D. Molenaar, G. Poelarends, H.W. van Veen, B. Poolman, A.J.M. Driessen, and W.N. Konings. 1994. Proton motive force-driven and ATP-dependent drug extnusion systems in multidrug-resistant Lactococcus lactis. J. Bacteriol. 176:6957-6964.

7. Boorstin, D.J. 1991. p. 491-503 in The discoverers, Harry N. Abrams Inc. New York, USA.

8. Bovill, R.A., J.A. Shallcross, and B.M. Mackey. 1994. Comparison of the fluorescent redox dye 5-cyano2,3-ditolyltetrazolium chloride with $p$-iodonitrotetrazolium violet to detect metabolic activity in heat-stressed Listeria monocytogenes cells. J. Appl. Bacteriol. 77:353-358.

9. Breeuwer, P., J.L. Drocourt, F.M. Rombouts, and T. Abee. 1994. Energy-dependent, carrier mediated extrusion of carboxyfluorescein from Saccharomyces cerevisiae allows rapid assessment of cell viability by flow cytometry. Appl. Environ. Microbiol. 60:1467-1472.

10. Breeuwer, P., J.L. Drocourt, N. Bunschoten, M.H. Zwietering, F.M. Rombouts and T. Abee. 1995. Characterization of uptake and hydrolysis of fluorescein diacetate and carboxyfluorescein diacetate by intracellular esterases in Saccharomyces cerevisiae, which result in accumulation of fluorescent product. Appl. Environ. Microbiol. 61:1614-1619.

11. Breeuwer, P., J.L. Drocourt, F.M. Rombouts, and T. Abee. 1996. A novel method for continuous determination of the intracellular $\mathrm{pH}$ in bacteria using the internally conjugated probe 5 -(and-6)-carboxyfluorescein succinimidyl ester. Appl. Environ. Microbiol 62:178-183.

12. Breeuwer, P. Unpublished data.

13. Bright, G.R., G.W. Fischer, J. Rogowska, and D.L. Taylor. 1989. Fluorescence ratio imaging microscopy. p. 157-192. In D. Lansing Taylor and Y. Wang, (ed.), Methods in Cell Biology, Vol. 30. Academic Press, Inc., London, UK.

14. Buchrieser, C., and C.W. Kaspar. 1993. An improved direct viable count for the enumeration of bacteria in milk. Intern. J. Food Microbiol. 20:227-236.

15. Byrd, J.J., H.S. Xu, and R.R. Colwell. 1991. Viabie but nonculturable bacteria in drinking water. Appl. Environ. Microbiol. 57:875-878.

16. Camphell, I.D., and R.A. Dwek. 1984. p. 91-125. In Biological Spectroscopy, Benjamins/Cummings Publishing Company Inc. Menlo Park, California, USA.

17. Chrzanowski, T.H., R.D. Crotty, J.G. Hubbard, and R.P. Welch. 1984. Applicability of the fluorescein diacetate method of detecting active bacteria in freshwater. Microb. Ecol. 10:179-185.

18. Coallier, J., M. Prévost, and A. Rompré. 1994. The optimization and application of two direct viable count methods for bacteria in distributed drinking water. Can. J. Microbiol. 40:830-836.

19. Coleman, A.W. 1980. Enhanced detection of bacteria in natural environments by tluorochrome staining of DNA. Limnol. Oceanogr. 25:948-951.

20. Colwell, R.R., P.R. Brayton, D.J. Grimes, D.B. Roszak, S.A. Huq, and L.M. Palmer. 1985. Viable but non-culturable Vibrio cholerae and related pathogens in the environment: implications for release of genetically engineered microorganisms. Bio/Technology 3:817-820.

21. Costantino, P.J., D.E. Budd, and N.F. Gare. 1995. Enumeration of viable Candida albicans blastospores using tetrabromofluorescein (Eosin $Y$ ) and flow cytometry. Cytometry 19:370-375.

22. De Beer, D., R. Srinivasan, and P.S. Stewart. 1994. Direct measurement of chlorine penetration into biofilms during disinfection. Appl. Environ. Microbiol. 60:4339-4344,

23. Deere, D., J. Porter, C. Edwards, and R. Pickup. 1995. Evaluation of the suitability of bis-(1,3dibutylbarbituric acid)trimethine oxonol, $\left(\mathrm{DiBA}^{-\mathrm{C}_{4}(3)}\right)$, for the flow cytometric assessment of bacterial viability. FEMS Microbiol. Lett. 130:165-170.

24. Desmonts, C., J. Minet, R.R. Colwell, and M. Cornier. 1990. Fluorescent-antibody method useful for detecting viable but non-culturable Salmonella spp. in chlorinated wastewater. Appl. Environ. Microbiol. 56:1448-1452.

25. Diaper, J.P., and C. Edwards. 1994. Survival of Staphylococcus aureus in lakewater monitored by flow 
cytometry. Microbiol. 140:35-42.

26. Dinsdale, M.G., D. Lloyd, and B. Jarvis. 1995. Yeast vitality during cider fermentation: two approaches to the measurement of membrane potential. J. Inst. Brew. 101:453-458.

27. Donnely, C.W., and G.J. Baigent. 1986. Method of flow cytometric detection of Listeria monocytogenes in milk. Appl. Environ. Microbiol. 52:689-695.

28. Duncan, S., L.A. Glover, K. Killham, and J.I. Prosser. 1994. Luminescence-based detection of starved and viable but nonculturable bacteria.

29. Dupray, E., M. Pommepuy, A. Derrien, M.P. Caprais, and M. Cormier. 1993. Use of direct viable count (DVC) for the assessment of survival of $E$. coll in marine environments. Wat. Sci. Tech. 27:395-399.

30. Dutton, R.J., G. Bitton, and B. Koopman. 1983. Malachite Green-INT (MINT) method for determining active bacteria in sewage. Appl. Environ. Microbiol. 46:1263-1267.

31. Ehrenberg, B., V. Montana, M.-D. Wei, J.P. Wuskell, and L.M. Loew. 1988. Membrane potential can be determined in individual cells from the nernstian distribution of cationic dyes. Biophys. J. 53:785-794.

32. Fouchet, P., C. Jayat, Y. Héchard, M.H. Ratinaud, and G. Frélat. 1993. Recent advances of flow cytometry in fundamental and applied microbiology. Biol. Cell 78:95-109.

33. Gant, V.A., G. Warnes, I. Phillips, and G.F. Savidge. 1993. The application of flow cytometry to the study of bacterial responses to antibiotics. J. Med. Microbiol. 39:147-154.

34. García-Lara, J., J. Martínez, M. Vilamú, and J. Vives-Rego. 1993. Effect of previous growth conditions on the starvation-survival of Escherichia coli in seawater. J. Gen. Microbiol. 139:1425-1431.

35. Goss, W.A., W.H. Deitz, and T.M. Cook. 1964. Mechanism of action of nalidixic acid on Escherichia coli. J. Bacteriol. 88:1112-1118.

36. Goss, W.A., W.H. Deitz, and T.M. Cook. 1965. Mechanism of action of nalidixic acid on Escherichia coli. II. Inhibition of deoxyribonucleic acid synthesis. J. Bacteriol. 89:1068-1074.

37. Gribbon, L.T., and M.R. Barer. 1995. Oxidative metabolism in non-culturable Heliobacter pylori and Vibrio vulnificus cells studied by substrate-enhanced tetrazolium reduction and digital image processing. Appl. Environ. Microbiol. 61:3379-3384.

38. Gross, D., and L.M. Loew. 1989. Fluorescent indicators of membrane potential: microspectrofluorimetry and imaging. p. 193-218. In D. Lansing Taylor and Y. Wang, (ed.), Methods in Cell Biology, Vol. 30. Academic Press, Inc., London, UK.

39. Haugland, R.P., and A. Minta. 1990. Design and application of indicator dyes. p. 1-20. In J.K. Foskett and S. Grinstein (ed.), Noninvasive techniques in cell biology. Wiley-Liss, New York, USA.

40. Haugland, R.P. 1992. In K.D. Larison (ed.), Handbook of fluorescent probes and research chemicals. Molecular Probes Inc., Eugene, USA.

41. Haworth, R.S., B.D. Lemire, D. Crandall, E.J. Cragoe, and L. Fliegel. 1991. Characterization of proton fluxes across the cytoplasmic membrane of the yeast Saccharomyces cerevisiae. Biochim. Biophys. Acta 1098:79-89.

42. Haworth, R.S., and L. Fliegel. 1993. Intracellular $\mathrm{pH}$ in Schizosaccharomyces pombe - comparison with Saccharomyces cerevisiae. Molec. Cell. Biochem. 124:131-140.

43. Hazeleger, W.C. J.D. Janse, P.M.F.J. Koenraad, R.R. Beumer, F.M. Rombouts, and T. Abee. 1995. Temperature-dependent membrane fatty acid and cell physiology changes in coccoid forms of Campylobacter jejuni. Appl. Environ. Microbiol. 61:2713-2719.

44. Hoff, K.A. 1988. Rapid and simple method for double staining of bacteria with 4',6-Diamidino-2Phenylindole and fluorescein isothiocyanate-labelled antibodies. Appl. Environ. Microbiol. 54:2949-2952.

45. Huang, C-T, F.P. Yu, G.A. McFeters, and P.S. Stewart. 1995. Nonuniform spatial patterns of respiratory activity within biofilms during disinfection. Appl. Environ. Microbiol. 61:2252-2256.

46. Hugenholtz, H. Veldkamp, and W.N. Konings. 1987. Detection of specific strains and variants of Streptococcus cremoris in mixed cultures by immunofluorescence. Appl. Environ. Microbiol. 53:149-155. 
47. Humphreys, M.J., R. Allman, and D. Lloyd. 1994. Determination of viability of Trichomonas vaginalis using flow cytometry. Cytometry 15:343-348.

48. Imai, T., and T. Ohno. 1995. The relationship between viability and intracellular $\mathrm{pH}$ in the yeast Saccharomyces cerevisiae. Appl. Environ. Microbiol. 61:3604-3608.

49. In 't Veld, G., A.J.M. Driessen, J.A.F. op den Kamp, and W.N. Konings. 1991. Hydrophobic membrane thickness and lipid-protein interactions of the leucine transport system of Lactococcus lactis. Biochim. Biophys. Acta 1065:203-212.

50. Jarnagin, J.L., and D.W. Luchsinger. 1980. The use of fluorescein diacetate and ethidium bromide as a stain for evaluating viability of mycobacteria. Stain Tech. 55:253-258.

51. Jepras, R.I., J. Carter, S.C. Pearson, F.E. Paul, and M.J. Wilkinson. 1995. Development of a robust flow cytometric assay for determining number of viable bacteria. Appl. Environ. Microbiol. 61:2696-2701.

52. Jones, K.H., and J.A. Senft. 1985. An improved method to determine viability by simultaneous staining with fluorescein diacetate and propidium iodide. J. Histochem. Cytochem. 33:77-79.

53. J $\phi$ rgensen, F., O. Nybroe, and S. Knфchel. 1994. Effect of starvation and osmotic stress on viability and heat resistance of Pseudomonas fluorescens AH9. J. Appl. Bacteriol. 77:340-347.

54. Kaneshiro, E.S., M.A. Wyder, Y-P. Wu, and M.T. Cushion. 1993. Reliability of calcein acetoxy methyl ester and ethidium homodimer or propidium iodide for viability assessment of microbes. J. Microbiol. Meth. 17:1-16.

55. Kaprelyants, A.S., and D.B. Kell. 1992. Rapid assessment of bacterial viability and vitality by rhodamine 123 and flow cytometry. J. Appl. Bacteriol. 72:410-422.

56. Kaprelyants, A.S., and D.B. Kell. 1993. The use of 5-cyano-2,3-ditolyl tetrazolium chloride and flow cytometry for the visualisation of respiratory activity in individual cells of Micrococcus luteus. J. Micrbiol. Meth. 17:115-122.

57. Kaprelyants, A.S., and D.B. Kell. 1993. Dormancy in stationary-Phase cultures of Micrococcus luteus: flow cytometric analysis of starvation and resuscitation. Appl. Environ. Micrbiol. 59:3187-3196.

58. Kepner, R.L., J.R. Pratt. 1994. Use of fluorochromes for direct enumeration of total bacteria in environmental samples: past and present. Microbiol. Rev. 58:603-615.

59. Kessel, D., W.T. Beck, D. Kukuruga, and V. Shulz. 1991. Characterization of multidrug resistance by fluorescent dyes. Cancer Res. 51:4665-4670.

60. King, L.K., and B.C. Parker. 1988. A simple, rapid method for enumerating total viable and metabolically active bacteria in groundwater. Appl. Environ. Microbiol. 54:1630-1631.

61. Kogure, K., U. Simidu, and N. Taga. 1979. A tentative direct microscopic method for counting living marine bacteria. Can. J. Microbiol. 25:415-420.

62. Krasznai, Z., T. Márián, L. Balkay, M. Emri, and L. Trón. 1995. Flow cytometric determination of absolute membrane potential of cells. J. Photochem. Photobiol. B: Biol. 28:93-99.

63. Latt, S.A. 1990. Fluorescent probes of DNA microstructure and synthesis. p. 263-284. In M.R. Melamed, T. Lindmo and M.L. Mendelsohn (ed.). Flow cytometry and sorting. Wiley-Liss Inc, New York, USA.

64. Lesher, G.Y., E.J. Froelich, M.D. Gruett, J.H. Bailey, and R.P. Brundage. 1962. 1,8-Naphthyridine derivatives: a new class of chemotherapeutic agents. J. Med. Pharm. Chem. 5:1063-1065.

65. Lindeboom, G.A. 1982. Leeuwenhoek and the problem of sexual reproduction. p. 129-152. In L.C. Palm and H.M. Snelders, (ed.), Antoni van Leeuwenhoek 1632-1723. Editions Rodopi B.V., Amsterdam. The Netherlands.

66. Lolkema, J.S., K.J. Hellingwerf, and W.N. Konings. 1982. The effect of probe binding on the quantitative determination of the proton-motive force in bacteria. Biochim. Biophys. Acta 681:85-94.

67. López-Amoróz, R., J. Comas, and J. Vives-Rego. 1995. Flow cytometric assessment of Escherichia coli and Salmonella typhimurium starvation-survival in seawater using Rhodamine 123, Propidium lodide and Oxonol. Appl. Environ. Microbiol. 61:2521-2526. 
68. Lundgren, B. 1981. Fluorescein diacetate as a stain of metabolically active bacteria in soil. Oikos. 36:17-22.

69. Manafi, M., W. Kneifel, and S. Bascomb. 1991. Fluorogenic and Chromogenic substrates used in bacterial diagnostics. Microbiol. Rev. 55:335-348.

70. Mason, C.A., G. Hamer, and J.D. Bryers. 1986. The death and lysis of microorganisms in environmental processes. FEMS Microbiol. Rev. 39:373-401.

71. Mason, D., R. Allman, and D. Lloyd. 1993. Uses of membrane potential dyes with bacteria. p. 67-81. $I n$ D. Lloyd (ed.), Flow Cytometry in Microbiology, Springer-Verlag, London, UK.

72. Mason, D.J., R. Allman, J.M. Stark, and D. Lloyd. 1994. Rapid estimation of bacterial antibiotic susceptibility with flow cytometry. J. Microsc. 176:8-16.

73. Mason, D.J., R. López-Amoróz, R. Alman, J.M. Stark, and D. Lloyd. 1995. The ability of membrane potential dyes and calcofluor white to distinguish between viable and non-viable bacteria. J. Appl. Bacteriol. 78:309-315.

74. Massaro, E.J., K.H. Elstein, R.M. Zucker, and K.W. Bair. 1989. Limitations of the fluorescent probe viability assay. Mol. Toxicol. 2:271-284.

75. Mathies, R.A., and L. Stryer. 1986. Single molecule fluorescence detection: a feasibility study using phycoerythrin. p. 129-140. In D.L. Taylor, A.S. Waggoner, R.F. Murphy, F. Lanni, and R. Birge, (ed.). Applications of fluorescence in the biomedical sciences. Alan R. Liss. New York, USA.

76. Matsuyama, T. 1984. Staining of living bacteria with rhodamine 123. FEMS Microbiol. Lett. 21:153-157.

77. McCLelland, R.G., and A.C. Pinder. 1994. Detection of low levels of specific Salmonella species by fluorescent antibodies and flow cytometry. J. Appl. Bacteriol. 77:440-447.

78. McDonald, R.M. 1980 . Cytochemical demonstration of catabolism in soil microorganisms. Soil Biol. Biochem. 12:419-423.

79. McFeters, G.A., F.P. Yu, B.H. Pyle, and P.S. Stewart. 1995. Physiological methods to study biofilm disinfection. J. Indus. Microbiol. 15:333-338.

80. Midgley, M. 1987. An efflux system for cationic dyes and related compounds in Escherichia coli. Microbiol Sci. 4:125-127.

81. Molenaar, D., T. Abee, and W.N. Konings. 1991. Continuous measurement of the cytoplasmic pH in Lactococcus lactis with a fluorescent $\mathrm{pH}$ indicator. Biochim. Biophys. Acta 1115:75-83.

82. Molenaar, D., H. Bolhuis,T. Abee, B. Poolman, and W.N. Konings. 1992. The efflux of a fluorescent probe is catalyzed by an ATP-driven extrusion system in Lactococcus lactis. J. Bacteriol. 174:3118-3124.

83. Moll, G., T. Ubbink-Kok, H. Hildeng-Hauge, J. Nissen-Meyer, I.F. Nes, W.N. Konings, and A.J.M. Driessen. 1996. Lactococcin $\mathrm{G}$ is a potassium ion-conducting two-component bacteriocin. J. Bacteriol. 178:600-605.

84. Morgan, J.A.W., G. Rhodes, and R.W. Pickup. 1993. Survival of nonculturable Aeromonas salmonicida in lake water. Appl. Environ. Microbiol. 59:874-880.

85. Mujumbar, R.B., L.A. Ernst, S.R. Mujumbar, and A.S. Waggoner. 1989. Cyanine dye labeling reagents containing isothiocyanate groups. Cytometry 10:11-19.

86. Neyfakh, A.A., V.E. Bidnenko, and L.B. Chen. 1991. Efflux-mediated multidrug resistance in Bacillus subtilis: similarities and dissimilarities with the mammalian system. Proc.Natl.Acad.Sci.USA 88:4781-4785.

87. Nilsson, L., J.D. Oliver, and S. Kjelleberg. 1991. Resuscitation of Vibrio vulnificus from the viable but non-culturable state. J. Bacteriol. 173:5054-5059.

88. Nwoguh, C.E., C.R. Harwood, and M.R. Barer. 1995. Detection of induced B-galactosidase activity in individual non-culturable cells of pathogenic bacteria by quantitative cytological assays. Mol. Microbiol. 17:545-554.

89. Oi, V., A.N. Glazer, and L. Stryer. 1982. Fluorescent phycobiliprotein conjugates for analysis of cells and proteins. J. Cell. Biol. 93:981-986.

90. Oliver, J.D., L. Nilsson, and S. Kjelleberg. 1991. Formation of nonculturable Vibrio vulnificus cells and its 
relationship to the starvation state. Appl. Environ. Microbiol. 57:2640-2644.

91. Oliver, J.D., F. Hite, D. McDougald, N.L. Andon, and L.M. Simpson. 1995. Entry in, and resuscitation from, the viable but non-culturable state by Vibrio vulnificus in an estuarine environment. Appl. Environ. Microbiol. 61:2624-2630.

92. Paul, J.H. 1982. Use of Hoechst 33285 and 33342 for enumeration of attached and planktonic bacteria. Appl. Environ. Microbiol, 43:939-944.

93. Paull, K.D., R.H. Shoemaker, M.R. Boyd, J.L. Parsons, P.A. Risbood, W.A. Barbera, M.N. Sharma, D.C. Baker,E. Hand,D.D.A. Scudiero,A. Monks,M.C. Alley, and M. Grote. 1988. The synthesis of XTT, a new tetrazolium dye that is bioreducible to a water-soluble formazan. J. Heterocyclic Chem. 25:911-913.

94. Pefia, A., S. Urbine, J.P. Pardo, and M. Borbolla. 1984. The use of cyanine dye in measuring membrane potential in yeast. Arch. Biochem. Biophys. 231:217-225.

95. Peña, A., J. Ramírez, G. Rosas, and M. Calahorra. 1995. Proton pumping and the internal pH of yeast cells, measured with pyranine introduced by electroporation. J. Bacteriol. 177:1017-1022.

96. Petit, J.M., M. Denis-Gay, and M.H. Ratinaud. 1993. Assessment of fluorochromes for cellular structure and function studies by flow cytometry. Biol. Cell. 78:1-13.

97. Petit, P.X., N. Glab, D. Marie, H. Kieffer, and P. Métézeau. 1996. Discrimination of respiratory dysfunction in yeast mutants by confocal microscopy, image, and flow cytometry. Cytometry 23:28-38.

98. Pettipher, G.L., R. Mansell, C.H. McKinnon, and C. Cousins. 1980. Rapid membrane filtrationepifluorescent microscopy technique for direct enumeration of bacteria in raw milk. Appl. Environ. Microbiol. 39:423-429.

99. Pinder, A.C. C. Edwards, R.G. Clarke, J.P. Diaper, and S.A.G. Poulter. 1993. Detection and enumeration of viable bacteria by flow cytometry. p. 67-85. In R.G. Kroll, A. Gilmour, and M. Sussman (ed), New techniques in food and beverage microbiology. Blackwell Scientific Publications, Oxford, UK.

100. Porro, D., B.M. Ranzi, C. Smeraldi, E. Martegani, B.M. Ranzi, and L. Alberghina. 1994. Flowcytometric determination of the respiratory activity in growing Saccharomyces cerevisiae populations. Biotechnol. Prog. 10:193-197.

101. Porro, D., B.M. Ranzi, C. Smeraldi, E. Martegani, and L. Alberghina. 1995. A double flow cytometric tag allows tracking of the dynamics of cell cycle progression of new borne Saccharomyces cerevisiae cells during balanced exponential growth. Yeast 11:1157-1169.

102. Porter, J., J. Robinson, R. Pickup, and C. Edwards. 1995. Recovery of a bacterial sub-population from sewage using immunofluorescent flow cytometry and cell sorting. FEMS Microbiol. Lett. 133:195-199.

103. Porter, J., D. Deere, R. Pickup, and C. Edwards. 1996. Fluorescent probes and flow cytometry: new insights into environmental bacteriology. Cytometry 23:91-96.

104. Porter, K.G., and Y.S. Feig. 1980. The use of DAPI for identifying and counting aquatic microflora. Limnol. Oceanogr. 25: 943-948.

105. Preyer, J.M., and J.D. Otiver. 1993. Starvation-induced thermal tolerance as a survival mechanism in a psychrophilic marine bacterium. Appl. Environ. Micrbjol. 59:2653-2656.

106. Pyle, B.H., S.C. Broadaway, and G.A. McFeters. 1995. A rapid, direct method for enumerating respiring enterohemorragic Escherichia coll $\mathrm{O} 157: \mathrm{H} 7$ in water. Appl. Environ. Microbiol. 61:2614-2619.

107. Quinn, J.P. 1984. The modification and evaluation of some cytochemical techniques for the enumeration of metabolically active heterotrophic bacteria in the aquatic environment. J. Appl. Bacteriol. 57:51-57.

108. Rabaste, F., M. Sancelme, A.M. Delort, J. Blais, and J. Bolard. 1995. Intracellular pH of Candida albicans blastospores as measured by laser microspectrofluorimetry and ${ }^{31}$ P-NMR. Biochim. Biophys. Acta 1268:41-49.

109. Ratinaud, M.H., J.M. Petit, and C. Cognard. 1994. Les fluorochromes utilisés en cytométry et leurs précautions d'emploi. p. 35-80. In P. Métézeau, M.H. Ratinaud and P. Carayon. (ed.), Techniques en cytométry par fluorescence: apports comparatifs des technigues flux, image et confocale. Éditions INSERM, 
Paris, France.

110. Rink, T.J., R.Y. Tsien, and T. Pozzan. 1982. Cytoplasmic pH and free $\mathrm{Mg}^{2+}$ in lymphocytes. J. Cell. Biol. 95:189-196.

111. Rodriguez, G.G., D. Phipps, K. Ishiguro, and H.F. Ridgway. 1992. Use of a fluorescent redox probe for direct visualization of actively respiring Bacteria. Appl. Environ. Microbiol. 58:1801-1808.

112. Rollins, D.M., and R.R. Colwell. 1986. Viable but nonculturable stage of Campylobacter jejuni and its role in survival in the natural aquatic environment. Appl. Environ. Microbiol. 52:531-538.

113. Ronot, X., L. Benel, M. Adolphe, and J.C. Mounolou. 1986. Mitochondrial analysis in living cells: the use of thodamine 123 and flow cytometry. Biol. Cell 57:1-8.

114. Roslev, P., and G.M. King. 1993. Application of a tetrazolium salt with a water-soluble formazan as an indicator of viability in bacteria. Appl. Environ. Microbiol. 59:2891-2896.

115. Roszak, D.B., D.J. Grimes, and R.R. Colwell. 1984. Viable but not recoverable stage of Salmonella enteritidis in aquatic systems. Can. J. Microbjol. 30:334-337.

116. Roszak, D.B., and R.R. Colwell. 1987. Survival strategies of bacteria in the natural environment. Microbiol. Rev. 51:365-379.

117. Rotman, B., and B.W. Papermaster. 1966. Membrane properties of living mammatian cells as studied by enzymatic hydrolysis of fluorogenic esters. Proc. Natl. Acad. Sci. USA 55:134-141.

118. Rouch, D.A., D.S. Cram, D. DiBerardino, T.G. Littlejohn, and R.A. Skurray. 1990. Efflux-mediated antiseptic resistance gene gacA from Staphylococcus aureus: common ancestry with tetracycline- and sugartransport proteins. Mol, Microbiol. 4:2051-2062.

119. Schaule, G., H.C. Femming, and H.F. Ridgway. 1993. Use of 5-Cyano-2,3-Ditolyl Tetrazolium Chloride for quantifying planktonic and sessile respiring bacteria in drinking water. Appl. Environ. Microbiol. 59:3850-3857.

120. Schnürer, J., and T. Rosswall. 1982. Fluorescein diacetate hydrolysis as a measure of total microbial activity in soil and litter. Appl. Environ. Micrbiol. 43:1256-1261.

121. Schupp, D.G., and S.L. Erlandsen. 1987. A new method to determine Giardia cyst viability: correlation of fluorescein diacetate and propidium iodide staining with animal infectivity. Appl. Environ. Microbiol. 53:704-707.

122. Schut, F., E. de Vries, J.C. Gottschal, B.R. Robertson, W. Harder. R.A. Prins, and D.K. Button. 1993. Isolation of typical marine bacteria by dilution culure: Growth, maintenance, and characteristics of isolates under laboratory conditions. Appl. Environ. Microbiol. 59:2150-2160.

123. Servis, N.A., S. Nichols, and J.C. Adams, 1995. Development of a direct viable count procedure for some gram-positive bacteria. Lett. Appl. Microbiol. 20:237-239.

124. Shapire, H.M. 1988. Practical flow cytometry. Alan R. Liss, Inc. New York.

125. Shapiro, H.M. 1990. Cell membrane potential analysis. p. 25-35. In Z. Darzynkiewicz and H.A. Crissman (ed.), Methods in Cell Biology, vol. 33. Academic Press, Inc., London, UK.

126. Sikkema, J., J.A.M. de Bont, and B. Poolman. 1994. Interactions of cyclic hydrocarbons with biological membranes. J. Biol. Chem. 269:8022-8028.

127. Singh, A., B.H. Pyle, and G.A. McFeters. 1989. Rapid enumeration of viable bacteria by image analyis. J. Microbiol. Meth. 10:91-101.

128. Singh, A., F.P. Yu, and G.A. McFeters. 1990. Rapid detection of chlorine-induced bacterial injury by the direct viable count method using image analysis. Appl. Environ. Microbiol. 56:389-394.

129. Smith, J.J., J.P. Howington, and G.A. McFeters. 1994. Survival, physiological response, and recovery of enteric bacteria exposed to a polar marine environment. Appl. Environ. Microbiol, 60:2977-2984.

130. Smith, J.J., and G.A. McFeters. 1996. Effects of substrates and phosphate on INT (2-(4-iodophenyl)-3-(4nitrophenyl)-5-phenyl tetrazolium chloride) and CTC (5-cyano-2,3-ditolyl tetrazolium chloride) reduction in Escherichia coli. J. Appl. Bacteriol. 80:209-215. 
131. Söderström, B.E. 1977. Vital staining of fungi in pure cultures and in soil with fluorescein diacetate. Soil Biol. Biochem. 9:59-63.

132. Steen, H.B., K. Skarstadt, and E. Boye. 1990. DNA measurements of bacteria, p. 519-527. In Z. Darzynkiewicz and H.A. Crissman (ed.), Methods in Cell Biology, vol. 33. Academic Press, Inc., London, UK.

133. Stellmach, J. 1984. Fluorescent redox dyes. 1. Production of fluorescent formazan by unstimulated and phorbol ester- or digitonin-stimulated Ehrlich ascites tumor cells. Histochem. 80:137-143.

134. Stewart, P.S., T. Griebe, R. Srinivasan, C.I. Chen, F.P. Yu, D. de Beer, and G.A. McFeters. 1994. Comparison of respiratory activity and culturability during monochloramine disinfection of binary population biofilms. Appl. Environ. Microbiol. 60:1690-1692.

135. Tabor, P.S., and R.A. Neihof. 1982. Improved method for determination of respiring individual microorganisms in natural waters. Appl. Environ. Microbiol. 43:1249-1255.

136. Tekola, P., J.P.A. Blaak, J.A.M. Beliën, and J. Brugghe. 1994. Highly sensitive, specific, and stable new fluorescent DNA stains for confocal laser microscopy and image processing of normal paraffin sections. Cytometry 17:191-195.

137. Tellier, R., M. Krajden, G.A. Grigoriew, and I. Campbell. 1992. Innovative endpoint determination system for antifungal susceptibility testing of yeasts. Antimicrob. Agents Chemother. 36:1619-1625.

138. Thom, S.M., R.W. Horobin, E. Seidler, and M.R. Barer. 1993. Factors affecting the selection and use of tetrazolium salts as cytochemical indicators of bacterial viability and activity. J. Appl. Bacteriol. 74:433-443.

139. Tsien, R.Y. 1989. Fluorescent indicators of ion indicators. p. 127-156. In D. Lansing Taylor and Y. Wang, (ed.), Methods in Cell Biology, Vol. 30. Academic Press, Inc., London, UK.

140. Tsien, R.Y., and A. Waggoner. 1990. Fluorophores for confocal microscopy: photophysics and photochemistry. p. 169-178. In J.B. Pawley (ed.), Handbook of biological confocal microscopy. Plenum Press, London, UK.

141. Tyndall, R.L., R.E. Hand, R.C. Mann, C. Evans, and R. Jernigan. 1985. Application of flow cytometry to detection and characterization of Legionella spp. Appl. Environ. Microbiol. 49:852-857.

142. Ueckert, J., P. Breeuwer, T. Abee, P. Stephens, G. Nebe von Caron, and P.F. ter Steeg. 1995. Flow cytometry applications in physiological study and detection of foodborne microorganisms. Int. J. Food Microbiol. 28:317-326.

143. Van der Waaij, L.A., G. Mesander, P.C. Limburg, and D. van der Waaij. 1994. Direct flow cytometry of anaerobic bacteria in human feces. Cytometry 16:270-279.

144. Vistica, D.T., P. Shekan, D. Scudiero, A. Monks, A. Pittman, and M.R. Boyd. 1991. Tetrazolium-based assays for cellular viability: a critical examination of selected parameters affecting formazan production. Canc. Res. 51:2515-2520.

145. Votyakova, T., A.S. Kaprelyants, and D.B. Kell. 1994. Influence of viable cells on the resuscitation of dormant cells in Micrococcus luteus cultures held in an extended stationary phase: the population effect. Appl. Environ. Microbiol. 60:3284-3291.

146. Waggoner, A.S. 1990. Fluorescent probes for flow cytometry. p. 209-225. In M.R. Melamed, T. Lindmo and M.L. Mendelsohn (ed.). Flow cytometry and sorting. Wiley-Liss Inc, New York, USA.

147. Walsh, S., H.M. Lappin-Scott, H. Stockdale, and B.N. Herbert. 1995. An asessment of the metabolic activity of starved and vegetative bacteria using two redox dyes. J. Microbiol. Meth. 24:1-9.

148. Whitaker, J.E., R.P. Haughland, F.G. Prendergast. 1991. Spectral and photophysical studies of Benzo(c)xanthene dyes: dual emission pH sensors. Anal. Biochem. 194:330-344.

149. Winding, A., S.J. Binnerup, and J. Sфrensen. 1994. Viability of indigenous soil bacteria assayed by respiratory activity and growth. Appl. Environ. Microbiol. 60:2869-2875.

150. Xu, H.S., N. Roberts, F.L. Singleton, R.W. Attwell, D.J. Grimes, and R.R. Colwell. 1982. Survival and viability of nonculturable Escherichia coll and Vibrio cholerae in the estuarine and marine environment. Microb. Ecol. 8:313-323. 
151. Yu, F.P., B.H. Pyle, and G.A. McFeters. 1993. A direct viable count method for the enumeration of attached bacteria and assessment of biofilm disinfection. J. Microbiol. Meth. 17:167-180.

152. Yu, F.P., and G.A. McFeters. 1994. Rapid in situ assessment of physiological activities in bacterial biofilms using fluorescent probes. J. Microbiol. Meth. 20:1-10.

153. Yu, F.P., and G.A. McFeters. 1994. Physiological responses of bacteria in biofilms to disinfection. Appl. Environ. Microbiol. 60:2462-2466.

154. Zaritsky, A., M. Kihara, and R.M. MacNab. 1981. Measurement of membrane potential in Bacillus subtilis: a comparison of lipophilic cations, rubidium ion, and a cyanine dye as probes. J. Membrane Biol. 63:215-231.

155. Zimmermann, R., R. Iturriaga, and J. Becker-Birck. 1978. Simultaneous determination of the total number of aquatic bacteria and the number thereof involved in respiration. Appl. Environ. Microbiol. 36:926-935. 


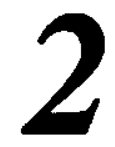

Characterization of Uptake and Hydrolysis of Fluorescein Diacetate and Carboxyfluorescein Diacetate by Intracellular Esterases in Saccharomyces cerevisiae, Which Result in Accumulation of Fluorescent Product

Pieter Breeuwer, Jean-Louis Drocourt, Natascha Bunschoten, Marcel H. Zwietering, Frank M. Rombouts, and Tjakko Abee.

This chapter was published in Applied and Environmental Microbiology 61:1614-1619. (1995) 


\begin{abstract}
Flow cytometry is a rapid and sensitive method which may be used for the detection of microorganisms in food and drinks. A key requirement for this method is a sufficient fluorescence staining of the target cells. The mechanism of staining of the yeast Saccharomyces cerevisiae by fluorescein diacetate (FDA) and 5-(and 6-) carboxyfluorescein diacetate (cFDA) was studied in detail. The uptake rate of the prefluorochromes increased in direct proportion to the concentration and was not saturable, which suggests that transport occurs via a passive diffusion process. The permeability coefficient for cFDA was $1.3 \times 10^{-8} \mathrm{~m} \mathrm{~s}^{-1}$. Once inside the cell, the esters were hydrolyzed by intracellular esterases and their fluorescent products accumulated. FDA hydrolysis (at $40^{\circ} \mathrm{C}$ ) in cell extracts could be described by first order reaction kinetics, and a rate constant (K) of $0.33 \mathrm{~s}^{-1}$ was calculated. Hydrolysis of cFDA (at $40^{\circ} \mathrm{C}$ ) in cell extracts was described by Michaelis-Menten kinetics with an apparent $V_{\max }$ and $K_{\mathrm{m}}$ of $12.3 \mathrm{nmol} \mathrm{min}^{-1} \cdot \mathrm{mg}$ protein ${ }^{-1}$ and $0.29 \mathrm{mM}$, respectively. Accumulation of fluorescein was most likely limited by the esterase activity, since transport of FDA was faster than the hydrolysis rate. In contrast, accumulation of carboxyfluorescein was limited by the much slower transport of cFDA through the cell envelope. A simple mathematical model was developed to describe the fluorescence staining. The implications for optimal staining of yeast cells with FDA and cFDA were discussed.
\end{abstract}

\title{
Introduction
}

There is an increasing demand in the food industry for rapid microbiological detection methods. Amongst other methods, flow cytometry is a relatively new and promising method for analysis of the microbial quality of foods. The method is already routinely used for the detection of yeasts in fermented milk products and for the detection of bacteria in frozen vegetables (9). In combination with fluorescence staining, flow cytometry potentially allows rapid and sensitive analysis of individual cells $(12,25)$.

One of the key factors in flow cytometric detection is the fluorescence labelling of the target (microbial) cells $(19,29)$. As outlined by Waggoner $(29)$, the ideal fluorochrome for flow cytometry should have a high extinction coefficient, a high quantum yield, and a low excited state lifetime. Furthermore, preferably, only viable cells should be fluorescently labelled. Fluorescein and fluorescein derivatives are widely used because they can be excited at the popular $488 \mathrm{~nm}$ line of an argon laser, because they have high extinction coefficients and high quantum yields (although pH dependent), and because they may be easily loaded into intact, esterase containing (viable) cells by incubation with the respective diacetyl esters $(28,29)$. 
The fluorescence signal of cells loaded with fluorescein or fluorescein derivatives depends largely on the intracellular concentration of the probe and the $\mathrm{pH}$. Basically, this concentration is the result of uptake and hydrolysis of the nonfluorescent precursor and efflux of the fluorescent product. It is generally assumed that nonpolar esterified compounds such as FDA diffuse freely into intact cells $(4,16,23-25,28)$, although this has never been verified. However, an active uptake mechanism for FDA in erythrocytes, $\mathrm{CHO}$ cells and $\mathrm{HeLa}$ cells has been suggested $(22,27)$.

After transport into the cells, the prefluorochrome is hydrolyzed into the more polar fluorescent products by intracellular esterases. Apparently, most cells, whether mammalian cells, yeast cells, or gram-positive or gram-negative bacteria, can hydrolyze FDA or cFDA $(2,5,21,24)$. A number of studies on the esterase activity of yeast cells $(10,17,18,31,33)$, which indicated that several different activities are present in $S$. cerevisiae have been carried out. However, generally, p-nitrophenyl acetate or naphthyl acetates were used as esterase substrates and there is no available information about FDA or cFDA conversion by intracellular esterases in yeast cells. The objective of this study was to determine the mechanism and the kinetics of membrane transport and intracellular hydrolysis of FDA and cFDA in S. cerevisiae, in order to optimize the fluorescence staining for the detection of yeasts in food products by flow cytometry.

\section{Materials and Methods}

Abbreviations. The following abbreviations are used in this report: $\mathrm{cF}, 5$-(and 6-)carboxyfluorescein; cFDA, 5-(and 6-)carboxyfluorescein diacetate; CE, cell extract; FDA, fluorescein diacetate.

Organism and growth conditions. Saccharomyces cerevisiae L1 15 (Chemunex S.A., Maisons-Alfort, France) was grown aerobically in Sabouraud broth (Oxoid Ltd., Basingstoke, Hampshire, UK.) at $30^{\circ} \mathrm{C}$. Cells were harvested by centrifugation $(5 \mathrm{~min}, 1500 \mathrm{x} \mathrm{g}$, at room temperature) at the end of the exponential growth phase at a cell concentration of approx. $3 \times 10^{7}$ per ml of broth (determined with a Bürker-Türker counting chamber, depth $0.1 \mathrm{~mm}$ ).

Uptake of FDA and cFDA. Cells were washed and resuspended in McIlvaine buffer, $\mathrm{pH} 7.3$ or $\mathrm{pH}$ 4.0, for transport experiments with FDA or cFDA, respectively (Mcllvaine buffer is composed of citric acid $[100 \mathrm{mM}]$ and disodium hydrogen phosphate dihydrate $[200 \mathrm{mM}]$, set to the desired $\mathrm{pH}$ ). The suspension (diluted to approx. $3 \times 10^{6}$ cells per $\mathrm{ml}$ ) was incubated in a $3 \mathrm{ml}$ fluorescence cuvette (path length, $10 \mathrm{~mm}$ ), stirred, and kept at $40^{\circ} \mathrm{C}$ in a temperature-stabilized cuvette-holder in a spectrofluorometer (Perkin-Elmer LS 50B, supplied with a pulsed Xenon light source). After $5 \mathrm{~min}$ preincubation, FDA or cFDA (from a stock solution in acetone) was added at various concentrations and the fluorescence was measured continuously for $15 \mathrm{~min}$ (excitation and emission wavelengths were 490 and $515 \mathrm{~nm}$, respectively, with slit widths of $2.5 \mathrm{~nm}$ ). The uptake rate was calculated from the initial (first minute) fluorescence increase and was expressed in $\mathrm{mmol} \cdot \mathrm{m}^{-3} \mathrm{~s}^{-1}$ or $\mathrm{nmol} \mathrm{min}^{-1} \mathrm{mg}$ of protein ${ }^{-1}$. The approximations used for the intracellular volume $\left(V_{i}\right)$ and the membrane surface $(S)$ were $70 \mu \mathrm{m}^{3}$ and 85 $\mu \mathrm{m}^{2}$, respectively (30). 
Flow cytometric analysis. Analysis of the fluorescence intensity of individual cells was performed

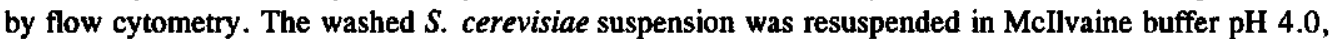
incubated for $10 \mathrm{~min}$ at $40^{\circ} \mathrm{C}$ with various cFDA concentrations, and cooled in ice for a minimum of $10 \mathrm{~min}$. The suspension was diluted 300 times and analyzed in duplicate with the flow cytometer (ChemFlow cytometer, Chemunex S.A., France) as described previously (3).

Preparation of cell extract. Washed cells were resuspended in Mclivaine buffer $\mathrm{pH} 7.3$, and passed 5 times through a French press (American Instrument Co., Inc., USA) at a pressure of $2.1 \times 10^{4} \mathrm{kPa}$. Remaining whole cells and cell debris were removed by centrifugation $(5 \mathrm{~min}, 3000 \mathrm{x}$, at room temperature). The CE was kept on ice until further use.

Enzyme assays. CE was preincubated at $40^{\circ} \mathrm{C}$ (unless indicated otherwise) for $3 \mathrm{~min}$ in McIlvaine buffer $\mathrm{pH}$ 7.3. Subsequently, FDA or cFDA was added to various final concentrations and incubated for $20 \mathrm{~min}$ at $40^{\circ} \mathrm{C}$. After $5,10,15$, and $20 \mathrm{~min}$, samples $(0.5 \mathrm{ml}$ in duplicate) were transferred to Eppendorf tubes which contained $0.5 \mathrm{ml}$ of ice-cold buffer and centrifuged immediately $(90 \mathrm{~s}$, $14000 \mathrm{x} \mathrm{g}$ ). The $A_{490}$ of the supernatant was measured in a Beckman DU 64 spectrophotometer (Beckman Instruments Co., USA). All data were corrected for nonenzymatic (chemical) hydrolysis by incubation of FDA or cFDA under the same conditions but in the absence of enzyme.

Enzymatic hydrolysis of cFDA in $S$. cerevisiae at various stages of growth. $S$. cerevisiae was inoculated (at approx. $5 \times 10^{5}$ cells per $\mathrm{ml}$ ) in Sabouraud broth and growth at $30^{\circ} \mathrm{C}$ was followed for $20 \mathrm{~h}$. The number of CFU (determined by pour plates with yeast extract glucose agar after appropriate dilution in $\mathrm{NaCl}[8.5 \mathrm{~g} / 1]$ with neutralized bacteriological peptone $[1 \mathrm{~g} / \mathrm{l}]$ [Oxoid Ltd., Basingstoke]), protein content (mg of protein $\mathrm{ml}^{-1}$ ), and enzyme activity (nmol $\mathrm{min}^{-1} \mathrm{mg}$ protein ${ }^{-1}$ ) were determined (all in duplicate) at $2 \mathrm{~h}$ intervals. For determination of enzyme activity, $1.5 \mathrm{ml}$ of the cell suspension was permeabilized with $0.1 \%$ Triton $\mathrm{X}-100$ and immediately frozen at $-20^{\circ} \mathrm{C}(14)$. After thawing the samples were preincubated for $3 \mathrm{~min}$ at $40^{\circ} \mathrm{C}$ before cFDA $(50 \mu \mathrm{M})$ was added. After incubation, cells were removed by centrifugation and the supernatant was measured in the spectrophotometer as described above. The incubation time varied between 20 and $60 \mathrm{~min}$, depending on the growth phase.

Efflux of fluorescent product. The efflux rates of fluorescein and $\mathrm{cF}$ at $40^{\circ} \mathrm{C}$ in McIlvaine buffer $\mathrm{pH} 7.3$, and $\mathrm{pH} 4.0$, respectively, were determined in the absence of glucose as described previously (3).

Determination of cell protein content. The protein content was determined according to the method of Lowry et al. (11), using bovine serum albumin as a standard.

\section{Results}

FDA and cFDA accumulation in $S$. cerevisiae cells. Cells were incubated in the presence of increasing concentrations of FDA or cFDA, and the initial rate of fluorescent product formation was determined.

(i) FDA. The rate of fluorescein formation was determined as a function of the initial FDA concentration (Fig. 1A). At concentrations below the maximum solubility of FDA in water (approx. $10 \mu \mathrm{M}$ ), this relationship was linear. At higher concentrations the increase of the formation rate saturated rapidly, which was most likely caused by precipitation of FDA, resulting in lower concentrations of free FDA. 


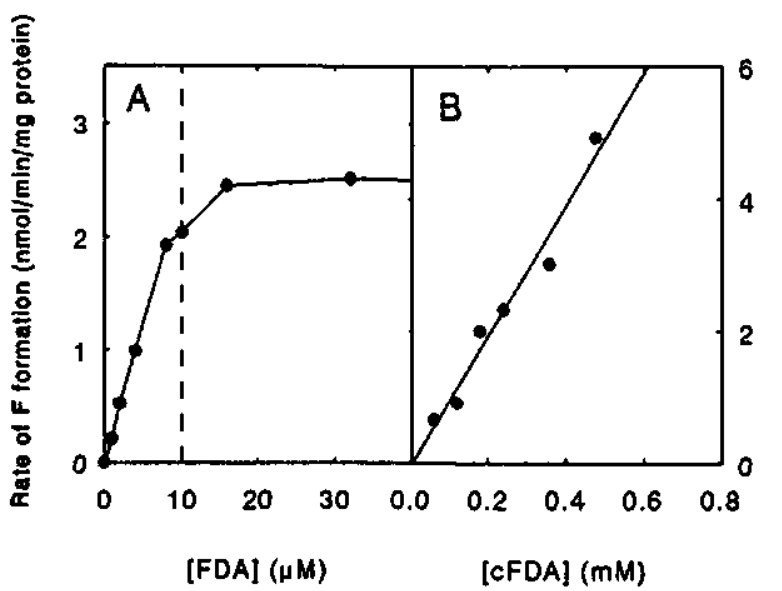

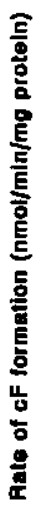

[FDA] $(\mu M) \quad[\mathrm{cFDA}](\mathrm{mM})$

FIG. 1. S. cerevisiae L115 cells were incubated at $40^{\circ} \mathrm{C}$ in the presence of increasing concentrations of FDA (A) and cFDA (B), and the initial rates of fluorescein $(\mathrm{F})$ and $\mathrm{cF}$ formation, respectively, were determined. The dashed line indicates the maximal solubility of FDA in $\mathrm{H}_{2} \mathrm{O}(\approx 10 \mu \mathrm{M})$. (The correlation coefficient for the fitted line in B was 0.982)

(ii) cFDA. The rate of $\mathrm{cF}$ formation increased linearly with the initial $\mathrm{cFDA}$ concentration (Fig. 1B). The fluorescence intensity of $S$. cerevisiae cells was additionally determined with a flow cytometer. The mean fluorescence intensity (the channel on the $x$ axis is a log value, since a logarithmic amplifier was used) of stained cells after $10 \mathrm{~min}$ incubation with the nonfluorescent precursor was also linearly related to the log of the initial cFDA concentration (Fig. 2).

Assuming that the transported FDA and cFDA are converted directly to their respective fluorescent products (infinite reaction rate), permeability coefficients $\left(\boldsymbol{P}_{d}\right)$ for FDA and cFDA

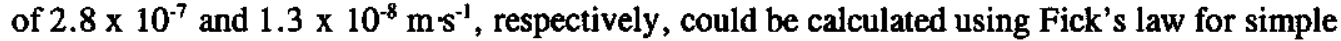
diffusion.

Determination of enzyme activity. The enzymatic hydrolysis of FDA and cFDA in CE from $S$. cerevisiae was characterized.

(i) Enzyme kinetics. CE $(0.52 \mathrm{mg}$ of protein per $\mathrm{ml})$ was incubated in the presence of various concentrations of FDA or cFDA, and the hydrolysis rate was determined at various times as a function of the prefluorochrome concentration (Fig. 3). As noticed earlier, FDA is only poorly soluble in water: hence, saturation of the hydrolysis rate was not necessarily a result of enzyme saturation. Consequently, hydrolysis of FDA could not be described by Michaelis-Menten kinetics. However, hydrolysis of soluble FDA could be described by first 


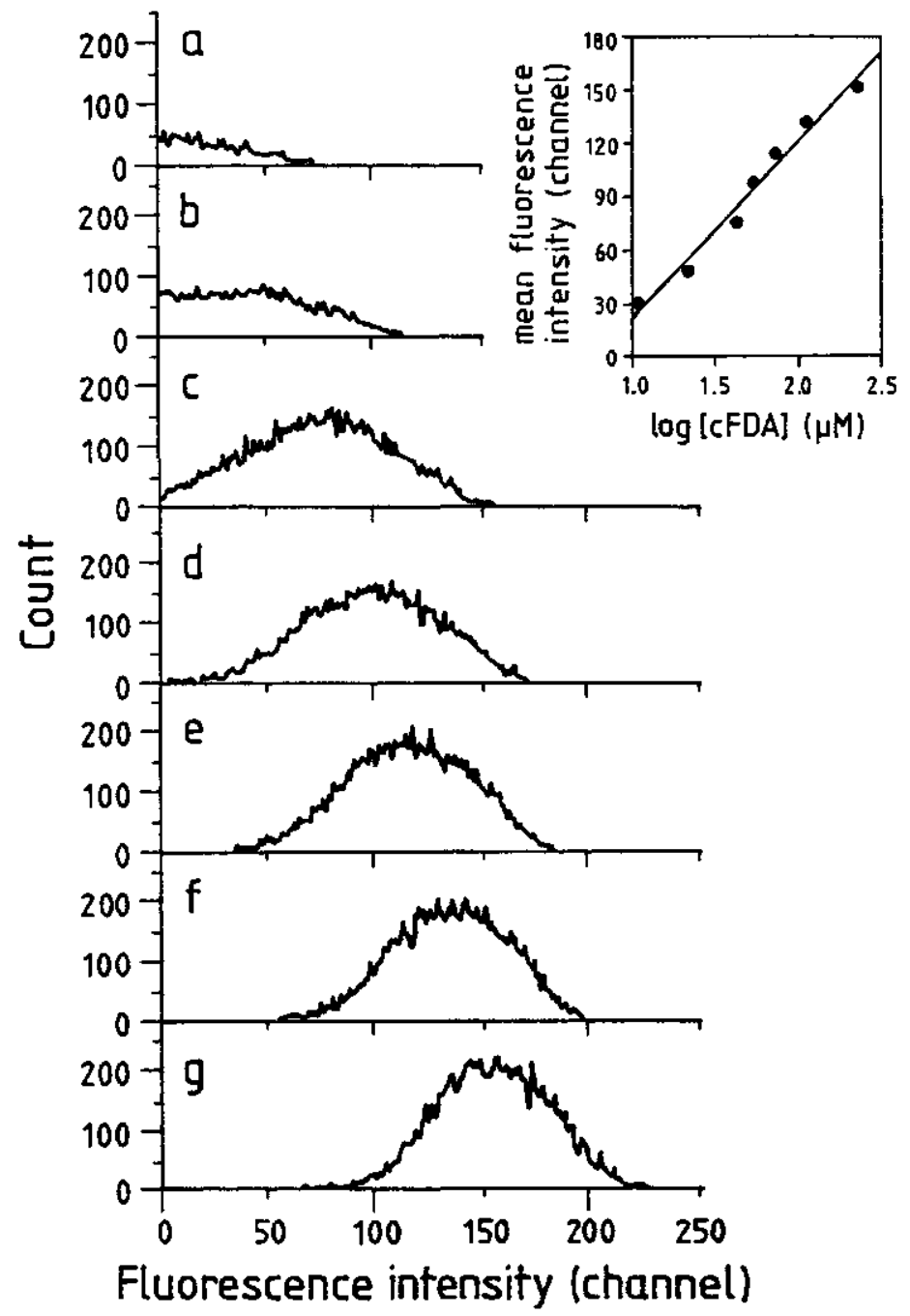

FIG. 2. Histograms of a $S$. cerevisiae population (approximately 10,000 cells) incubated for $10 \mathrm{~min}$ at $40^{\circ} \mathrm{C}$ in the presence of increasing concentrations of cFDA. cFDA concentrations: $11 \mu \mathrm{M}$ (a), $22 \mu \mathrm{M}$ (b), $43 \mu \mathrm{M}$ (c), $54 \mu \mathrm{M}$ (d), $72 \mu \mathrm{M}$ (e), $109 \mu \mathrm{M}$ (f), and $217 \mu \mathrm{M}$ (g). The fluorescence intensities were determined with a flow cytometer. Because a logarithmic amplifier was used, the channels on the $x$ axis are a $\log$ function of the fluorescence intensity. The inset shows the mean channel of the cell population calculated from the histograms as a function of the $\log$ of the cFDA concentration. 


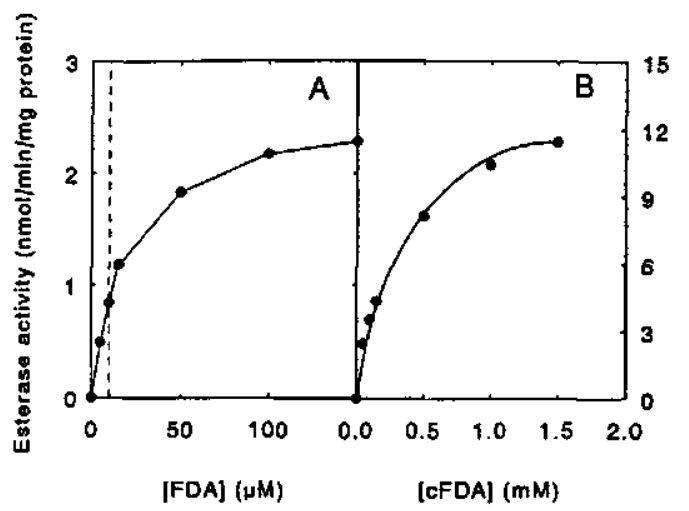

FIG. 3. Kinetics of FDA (A) and CFDA (B) hydrolysis at $40^{\circ} \mathrm{C}$ in $\mathrm{CE}$ from $S$. cerevisiae L115. The dashed line indicates the maximum solubility of FDA in water $(\approx 10 \mu \mathrm{M})$.

order reaction kinetics, and a hydrolysis coefficient of $1.5 \times 10^{-3} \mathrm{~s}^{-1}$ was calculated. The data for the cFDA hydrolysis were analyzed by means of a Hanes-Woolf plot (6), and an apparent $K_{m}$ of $0.29 \mathrm{mM}$ and a $V_{\max }$ of $12.3 \mathrm{nmol} \mathrm{min}^{-1} \mathrm{mg}$ of protein ${ }^{-1}$ were determined.

(ii) Temperature and $\mathrm{pH}$ optimum. $\mathrm{CE}$ was incubated at different temperatures and $\mathrm{pH}$ values and esterase activities were determined. At elevated temperatures $\left(>50^{\circ} \mathrm{C}\right)$ the enzyme activity (in $\mu \mathrm{mol}$ liter-1 $\mathrm{min}^{-1}$ ) significantly decreased during the incubation, most likely because of denaturation (data not shown). After $25 \mathrm{~min}$ the activity was the highest, at approx. $50^{\circ} \mathrm{C}$ (Fig. 4). The optimum pH for enzymatic hydrolysis of FDA and cFDA in Mcllvaine buffer at $40^{\circ} \mathrm{C}$ was approx. 7 for both substrates (Fig. 4B).

(iii) Hydrolysis of cFDA at various stages of growth of $S$. cerevisiae. The esterase activity in $S$. cerevisiae was determined during various stages of growth in Sabouraud broth by measuring the hydrolysis of cFDA in permeabilized cells. The esterase activity was approx. $1.5 \mathrm{nmol} \mathrm{min}^{-1} \mathrm{mg}$ protein ${ }^{-1}$ and remained constant during growth (Fig. 5).

Efflux of fluorescent product: The efflux rate at $40^{\circ} \mathrm{C}$ of fluorescein was linear with the intracellular concentration (up to $0.5 \mathrm{mM}$ ), and a first-order rate constant, $K_{e}$, of $3.17 \times 10^{-4}$ $\mathrm{s}^{-1}$ was determined. The efflux of $\mathrm{cF}$ saturated at high internal concentrations and obeyed Michaelis-Menten kinetics. At $40^{\circ} \mathrm{C}$, a $K_{m}$ of $0.34 \mathrm{mM}$ and a $V_{\max }$ of approx. 0.7 $\mathrm{nmol} \cdot \mathrm{min}^{-1} \mathrm{mg}$ of protein ${ }^{-1}$ were determined. 


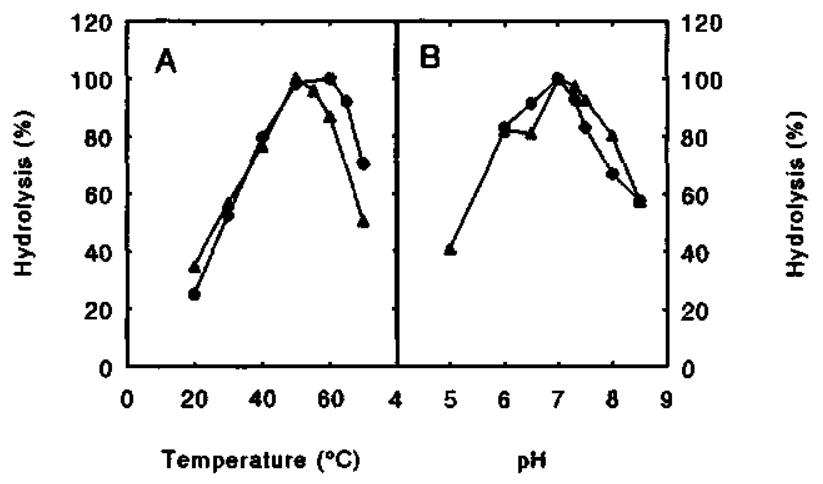

FIG. 4. Hydrolysis of FDA and CFDA in CE from S. cerevisiae L115 as a function of the temperature and $\mathrm{pH}$. CE was incubated in the presence of FDA $(15 \mu \mathrm{M})(\Theta)$ or cFDA $(50 \mu \mathrm{M})$ (A). (A) Samples were taken after 25 minutes incubation at $\mathrm{pH} 7.3$. Maximum enzyme activities (100\% values) were 0.44 and $1.21 \mu \mathrm{mol}^{\text {liter }}{ }^{-1} \mathrm{~min}^{-1}$ for FDA and cFDA, respectively. (B) Samples were taken after 25 minutes incubation at $40^{\circ} \mathrm{C}$ Maximum enzyme activities (100\% values) were 0.43 and $1.20 \mu \mathrm{mol} \mathrm{liter}^{-1} \mathrm{~min}^{-1}$ for FDA and cFDA, respectively.

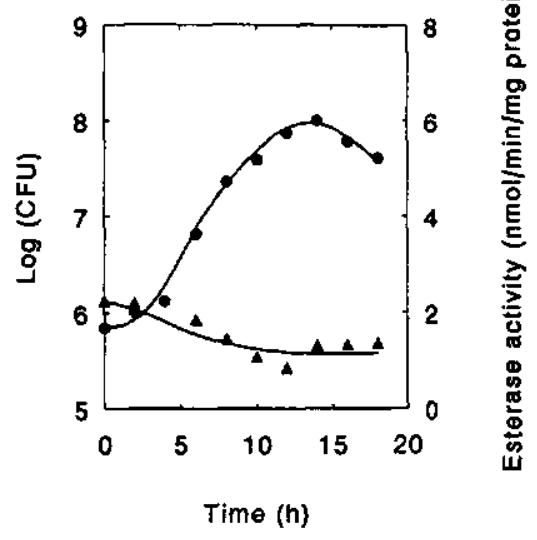

FIG. 5. Esterase activity of $S$. cerevisiae during various stages of growth. Cells were grown at $30^{\circ} \mathrm{C}$ in Sabouraud broth. CFU ( () ) and the specific esterase activity ( 1 ) with cFDA $(50 \mu \mathrm{M})$ were determined at 2-h intervals. For determination of the enzyme activity cells were permeabilized with Triton X-100 as described in Materials and Methods. 
Modelling of transport and enzyme kinetics. The kinetics of FDA and cFDA transport and conversion were described in a model analogous to the model developed by Wittrup and Bailey (32) for the transport and hydrolysis of Resorufin-B-D-galactopyranoside. The change in the extracellular substrate $\left(S_{o}\right)$ and the intracellular substrate concentration $\left(S_{i}\right)$ are described in equations 1 and 2 , respectively.

$$
\begin{gathered}
-\frac{d S_{o}}{d t}=k_{i}\left(S_{o}-S_{i}\right) \cdot \frac{V_{i}}{V_{o}} \\
\frac{d S_{i}}{d t}=k_{i}\left\langle S_{o}-S_{i}\right\rangle-R_{h} \\
\text { with } \quad R_{h}=\frac{v_{m[\text { enz }]} S_{i}}{K_{m[\text { enz }]}+S_{i}}
\end{gathered}
$$

In equation 3 the change of fluorescent product is described.

$$
\frac{d P}{d t}=R_{h}-\frac{V_{m[e f f]} P}{K_{m[e f f]}+P}
$$

$S_{i}$ and $S_{o}$ are measured in mol m $\mathrm{m}^{-3}$, respectively, $t$ is the time (in seconds), $k_{i}$ is the transport coefficient (per second), $V_{i}$ and $V_{o}$ are the intracellular and extracellular volumes (in $\mathrm{m}^{3}$ ), respectively, $R_{h}$ is the hydrolysis rate (in mol s$~^{-1} \mathrm{~m}^{-3}$ ), $V_{m}$ (in mol s $\mathrm{m}^{-3}$ ) and $K_{m}$ (in mol m $\mathrm{m}^{-3}$ ) are the Michaelis-Menten kinetic parameters of the esterase activity ( fenz ) and the efflux (eff), respectively, and $P$ is the intracellular fluorescent product concentration (in $\mathrm{mol} \mathrm{m} \mathrm{m}^{-3}$ ).

For the model, the following assumptions were made: (i) the enzymatic hydrolysis of cFDA can be described by Michaelis-Menten kinetics (equation 2B), (ii) the transport through the cell envelope is a simple diffusion process, (iii) the cytoplasmic concentrations are spatially homogeneous and (iv) the efflux of fluorescent product is an energy-dependent carrier-mediated extrusion process (3), which can be described by Michaelis-Menten kinetics (equation 3).

It was not possible to determine Michaelis-Menten parameters for both the enzymatic hydrolysis of FDA and subsequent efflux of fluorescein. However, at low concentrations the reactions can be described by first order kinetics. Consequently, the hydrolysis term $R_{h}$ in 
equation $2 A$ is $K_{h} S_{i}$, with $K_{h}$ (per second) being the first order reaction rate constant for intracellular FDA hydrolysis, and the efflux term in equation 3 was replaced by $K_{e} P$, with $K$, the first order rate constant for fluorescein efflux.

Equation 1, 2, and 3 may be solved numerically by using the definition of the derivative:

$$
\frac{d X}{d t}=\lim _{\Delta t 10} \frac{X(t+\Delta t)-X(t)}{\Delta t}
$$

resulting in

$$
X(t+\Delta t) \approx X(t)+\Delta t \cdot \frac{d X}{d t}
$$

With a small enough $\Delta t$, this equation can be iteratively used (Euler forwards [20]) to estimate the substrate and product concentration against time.

The parameters for the transport $\left(k_{i}\right)$, enzyme reaction $\left(v_{\text {mienz }}, K_{\text {m(enz } j}\right.$ or $\left.K_{h}\right)$ and efflux were experimentally determined independently (see above); for FDA and cFDA a $\mathrm{k}_{\mathrm{i}}$ of 0.83 and $0.034 \mathrm{~s}^{-1}$, respectively, were derived from the calculated $P_{d}$ value (it was assumed that the width of the cell envelope was $400 \mathrm{~nm}$ [22]). When equations 1, 2, and 5 are combined, the intracellular substrate concentration can be calculated as a function of time. For example, when the added extracellular cFDA concentration $\left(S_{o}\right.$ at $\mathrm{t}=0 \mathrm{~s}$ ) is $100 \mu \mathrm{M}$, the calculated maximum intracellular cFDA concentration during incubation is about $35 \mu \mathrm{M}$.

The solid line in Fig. $6 \mathrm{~A}$ shows the $\mathrm{cF}$ concentration after $3 \mathrm{~min}$ as a function of the extracellular prefluorochrome concentration, whereas the symbols represent the measured data. The model almost perfectly described the obtained data. It should be noted that all parameters were taken from independent experiments. The intracellular cFDA concentration and the accumulation in the ideal situation (i.e., infinite transport rate of cFDA and no efflux of $\mathrm{cF}$ ) were calculated as well (Fig. 6B). From this it can be concluded that both uptake of cFDA and efflux of $\mathrm{cF}$ are of eminent importance. These results suggest that the described model can be used to predict intracellular concentrations of the fluorescent products and also to predict whether the formation is transport (uptake) or enzyme limited.

\section{Discussion}

This paper describes the kinetics of fluorescein and $\mathrm{cF}$ accumulation in $S$. cerevisiae. Yeast cells may be loaded with fluorescein or cF by incubation with FDA or cFDA, respectively. Principally, accumulation of the fluorescent probes in intact $S$. cerevisiae cells is either transport limited or enzyme limited. With cFDA, the fluorescence increase rate in whole cells 


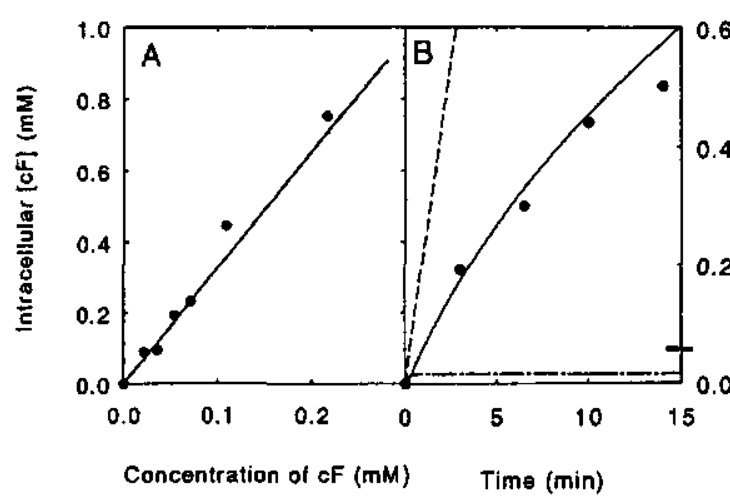

FIG. 6. Modelling of the intracellular cF concentration $\left(P_{i}\right)$. The $P_{i}$ after incubation at $40^{\circ} \mathrm{C}$ is shown as a function of the initial cFDA concentration after $3 \mathrm{~min}(\mathrm{~A})$ and as a function of time at an initial cFDA concentration of $0.054 \mathrm{mM}$ (B). The symbols represent the determined data. The solid lines were calculated with equation 3 . The $k_{i}, K_{\text {m|enz }]}$ and $K_{\text {m]eff], }} V_{m\{\text { enz }]}$ and $V_{m \text { m[eff }}$ were $0.034 \mathrm{~s}^{-1}, 0.29$ and $0.34 \mathrm{mM}$, and 0.023 and $1.17 \times 10^{-3} \mathrm{~mol} \mathrm{~s}^{-1} \mathrm{~m}^{-3}$, respectively (for the determination of the parameters, see Results). The dashed lines represent the intracellular cFDA concentration (- - - ), and the intracellular cF concentration $\left(P_{i}\right)$ at an infinite transport rate of cFDA and no efflux of $\mathrm{cF}(--)$. The bar on the right $y$ axis indicates the initial cFDA concentration.

was linear with the cFDA concentration and the process could not be described by MichaelisMenten kinetics. The cFDA transport rate was not saturated at high concentrations (up to 0.48 $\mathrm{mM}$ ), suggesting that uptake was a simple diffusion process.

According to the described model, the rate of $\mathrm{cF}$ accumulation becomes enzyme limited at very high cFDA concentrations (approx $0.4 \mathrm{mM}$ ). Furthermore, if the accumulation of cFDA were not transport limited, the product increase rate would be expected to be significantly higher than the experimental data (in this situation $S_{i}$ may be substituted by $S_{0}$ in equation 3 to calculate the product increase rate). These considerations have led us to the conclusion that under normal conditions (i.e., cFDA concentration in the $\mu \mathrm{M}$ range), the rate of $\mathrm{cF}$ formation is most likely transport limited.

For FDA the situation was much more complicated because of its low solubility, which made it impossible to demonstrate whether or not the uptake process was linear at higher concentrations. For the same reason it was not possible to correctly determine MichaelisMenten parameters of the hydrolysis. Furthermore, in whole cells, uptake and subsequent hydrolysis of FDA was slightly faster than the hydrolysis rate determined in CE. This 
inconsistency is most likely due to some loss of esterase activity after preparation of CFE. Uptake, hydrolysis, and efflux could be described by a mathematic model, as described in the Results. However, the preliminary assumption that all transported FDA was immediately hydrolyzed is probably incorrect. Consequently the permeability coefficient of FDA might be underestimated. In conclusion, the data describing uptake and hydrolysis of FDA were not adequate to draw a reliable conclusion about the uptake mechanism and kinetics of hydrolysis. However, the results suggest that fluorescein formation (in contrast to $\mathrm{cF}$ ) is most likely limited by the hydrolysis rate.

For flow cytometric detection of microorganisms in foods the two most important parameters are the fluorescence intensity of the cells and the background noise (together represented by the signal to noise ratio). The final fluorescence intensity of the yeast cells will depend principally on the following factors: (i) the intracellular concentration of the fluorescent product, which depends on the uptake of the prefluorochrome, esterase activity, and the efflux of the fluorescent product, and (ii) the intracellular $\mathrm{pH}\left(\mathrm{pH}_{\mathrm{in}}\right)$.

The points mentioned and other factors which determine the fluorescence staining of yeast cells are discussed briefly below:

(i). Uptake of pre-fluorochrome. Since transport most likely occurs via passive diffusion, a higher uptake rate through the cell envelope can be accomplished by a higher prefluorochrome concentration. Indeed, this was true for cFDA. This is not possible with FDA because of its low solubility. Uptake of FDA and cFDA by cells might be decreased by active extrusion from the plasma membrane. Recently, Homolya et al. (7) reported that several ester derivatives were extruded from the plasma membrane by the human multidrug transporter (MDR1 or P-glycoprotein) which was expressed in mouse fibroblasts. The MDR type of transporter has also been described in yeasts $(1,8)$. We did not, however, observe a difference in the development of fluorescence in $S$. cerevisiae cells in the presence of reserpine or verapamil, which are potent inhibitors of MDR transport systems (data not shown), indicating that FDA and cFDA were not actively extruded from the plasma membrane to the extracellular space by MDR-like systems.

(ii). Temperature. Uptake $(29,32)$, esterase activity (see above), and efflux (3), are influenced by the temperature. Consequently, determination of the optimum temperature is critical for fluorescence staining.

(iii). Esterase activity. The optimum $\mathrm{pH}$ and temperature indicate that the esterase activity is close to its maximal value at the staining conditions we used $\left(30\right.$ to $40^{\circ} \mathrm{C}$ and an intracellular pH of about 7). The maximal hydrolysis rates for FDA and CFDA were about 2 and 12 $\mathrm{nmol} \mathrm{min}^{-1} \mathrm{mg}$ of protein ${ }^{-1}$, respectively, taking into account that the FDA hydrolysis rate was probably limited by the low solubility of FDA. These values are of the same order as the activity determined for the crude homogenate of Ehrlich ascites (approx. $7.5 \mathrm{nmol} \mathrm{min}^{-1} \mathrm{mg}$ of protein ${ }^{-1}$, measured at $\mathrm{pH} 7.4$ with FDA [10 $\left.\mu \mathrm{M}\right]$ as substrate [28]). Information about the esterase activity during growth of yeast cells is limited. Values of approx. 13 and 3 
$\mathrm{nmol} \cdot \mathrm{min}^{-1} \cdot \mathrm{mg}^{-1}$ of dry weight for low- and high-density $S$. cerevisiae cultures, respectively were reported with 1-naphthyl acetate (31). We have shown that the esterase activity remained essentially constant during growth of $S$. cerevisiae.

(iv). $\mathbf{p H}_{\mathrm{in}}$. The $\mathrm{pH}_{\mathrm{in}}$ is very important, principally because the fluorescence of fluorescein and $\mathrm{cF}$ is highly $\mathrm{pH}$ dependent (13), but also because $\mathrm{pH}_{\mathrm{in}}$ affects the enzyme activity (see above) and can influence passive efflux, as the $\mathrm{pH}_{\mathrm{in}}$ influences protonation of fluorescein and $\mathrm{cF}$ (28). The $\mathrm{pH}_{\text {in }}$ can be augmented by addition of an energy source (26), but this will also increase the (energy-dependent) efflux of FDA and cFDA (3), resulting in decreased fluorescence staining. Increase of the buffer $\mathrm{pH}$ to raise the $\mathrm{pH}_{\mathrm{in}}$ is frustrated by chemical hydrolysis of FDA and cFDA in an alkaline environment.

(v). Efflux. Efflux of fluorescent probes in S. cerevisiae occurs most likely via an energydependent, carrier-mediated transport mechanism (3). The efflux rate (see above) is significantly lower than the rate of uptake and the rate of hydrolysis of the esterified compound, but it is not a negligible factor. In order to prevent efflux of fluorescent compounds in cells, the presence of fermentable sugars should be avoided. Alternatively, the cells can be deenergized with e.g. benzoic acid, dinitrophenol, and diethylstilbestrol (2). However, under the conditions used to load the cells with cFDA, these compounds will decrease the $\mathrm{pH}_{\mathrm{in}}$, resulting in a reduced fluorescence intensity.

(vi). Fluorescent quenching. When the intracellular concentrations of Fluorescein and $\mathrm{cF}$ are too elevated, quenching occurs (29). In liposomes, quenching of 6-carboxyfluorescein was observed at concentrations above $2 \mathrm{mM}$ (4). To obtain optimal signal to noise ratios, relatively high intracellular $\mathrm{cF}$ concentrations (in the millimolar range) are needed. Further increase of the $\mathrm{cF}$ concentration to improve staining is likely to be limited by quenching.

In conclusion, we have shown that the staining of microorganisms is a very complex process which depends on several parameters that are often interdependent. Therefore, a good understanding of the staining mechanism and subsequent optimization of the prefluorochrome concentration, $\mathrm{pH}$, temperature, etc., is essential to obtain a sufficient staining of microorganisms. The results suggest that improved staining of yeast cells can be obtained most easily by increasing the prefluorochrome concentration and optimizing the temperature of incubation. In this respect, the mathematic model might be helpful to predict the influence of the various parameters (see above) on the intracellular fluorescent compound concentration. Finally, this should allow a better detection of yeasts in foods by flow cytometry.

\section{Acknowledgments}

This work was financially supported by the E.C. mobility grant B/AGRE-910059 in the framework of the ECLAIR programme. 


\section{References}

1. Bissinger, P.H., and K. Kuchler. 1994. Molecular cloning and expression of the Saccharomyces cerevisiae STSI gene product. A yeast $\mathrm{ABC}$ transporter conferring mycotoxin resistance. J. Biol. Chem. 269:4180-4186.

2. Breeuwer, P., J.L. Drocourt, and T. Abee. Unpublished data.

3. Breeuwer, P., J.L. Drocourt, F.M. Rombouts, and T. Abee. 1994. Energy-dependent, carrier mediated extrusion of carboxyfluorescein from Saccharomyces cerevisiae allows rapid assessment of cell viability by flow cytometry. Appl. Environ. Microbiol. 60:1467-1472.

4. Chen, R.F., and J.R. Knutson. 1988. Mechanism of fluorescence quenching of carboxyfluorescein in liposomes: energy transfer to nonfluorescent dimers. Anal. Biochem. 172:61-77.

5. Chrzanowskj, T.H., R.D. Crotty, J.G. Hubbard, and R.P. Welch. 1984. Applicability of the fluorescein diacetate method of detecting active bacteria in freshwater. Microb. Ecol. 10:179-185.

6. Cornish-Bowden, A. 1976. Principles of enzyme kinetics. Butterworths, London.

7. Homolya, L., Z. Hollo, U.A. Germann, I. Pastan, M.M. Gottesman, and B. Sarkadi. 1993. Fluorescent cellular indicators are extruded by the multidng resistance protein. J. Biol. Chem. 268:21493-21496.

8. Kuchler, K., R.E. Sterne, and J. Thorner. 1989. Saccharomyces cerevisiae STE6 gene product: a novel pathway for protein export in eucaryotic cells. EMBO J. 8:3973-3984.

9. Laplace-Builhé, C., K. Hahne, W. Hunger, Y. Tirilly, and J.L. Drocourt. 1993. Application of flow cytometry to rapid microbial analysis in food and drink industries. Biol. Cell. 78:123-128.

10. Lloyd, G.I., E.O. Morris, and Smith J.E. 1971. A study of the esterases and their function in Candida lipolytica, Aspergillus niger and a yeast-like fungus. J. Gen. Microbiol. 63:141-150.

11. Lowry, O.H., N.J. Rosebrough, A.L. Farr, and R.J. Randall. 1951. Protein measurement with the folin phenol reagent. J. Biol. Chem. 193:265-275.

12. Mackenzie, N.M., and A.C. Pinder. 1988. The use of flow cytometry in veterinary diagnosis and the food processing industry. p. 255-264. In B.A. Morris, N.N. Clifford and R. Jackman (ed.), Immunoassays for veterinary and food analysis - I. Elsevier Applied Science, Essex, United Kingdom.

13. Martin, M.M., and L. Lindqvist. 1975. The $\mathrm{pH}$ dependence of fluorescein fluorescence. J. Luminescence $10: 381-390$.

14. Miozzari, G.F., P. Niederberger, and R. Hütter. 1978. Permeabilization of microorganisms by triton X-100. Anal. Biochem. 90:220-233.

15. Molenaar, D., H. Bolhuis, T. Abee, B. Poolman, and W.N. Konings. 1992. The efflux of a fluorescent probe is catalyzed by an ATP-driven extrusion system in Lactococcus lactis. J. Bacteriol. 174:3118-3124.

16. Nedergaard, M., S. Desai, and W. Pulsinelli. 1990. Dicarboxy-dichlorofluorescein: a new fluorescent probe for measuring acidic intracellular $\mathrm{pH}$. Anal. Biochem. 187:109-114.

17. Parkkinen, E. 1980. Multiple forms of carboxylesterases in baker's yeast. Cell. Mol. Biol. 26:147-154.

18. Parkkinen, E., E. Oura, and H. Suomalainen. 1978. The esterases of baker's yeast. I. Activity and localization in the yeast cell. J. Inst. Brew. 84:5-8.

19. Petit, J.M., M. Denis-Gay, and M.H. Ratinaud. 1993. Assessment of fluorochromes for cellular structure and function sudies by flow cytometry. Biol. Cell. 78:1-13.

20. Press, W.H., B.P. Flannery, S.A. Teukolsky, and W.T. Vetterling. 1989. Numerical recipes in Pascal, p. 602 Cambridge University Press, Cambridge, U.K.

21. Prosperi, E. 1990. Intracellular turnover of fluorescein diacetate. Influence of membrane ionic gradients on fluorescein efflux. Histochem. J. 22:227-233.

22. Robinow, C.F., and B.F. Johnson. 1991. Yeast cytology: an overview, p. 7-120. In A.H. Rose and J.S. Harrison (ed.), The yeasts, vol. 4. Yeast organelles. Academic press, London, U.K.

23. Rotman, B., and B.W. Papermaster. 1966. Membrane properties of living mammalian cells as studied by enzymatic hydrolysis of fluorogenic esters. Proc. Natl. Acad. Sci. USA 55:134-141. 
24. Sengbusch, G.V., C. Couwenberg, J. Kühner, and U. Müller. 1976. Fluorogenic substrate turnover in single living cells. Histochem. J. 8:341-350.

25. Shapiro, H.M. 1988. Practical flow cytometry. Alan R. Liss, Inc., New York.

26. Sigler, K., and M. Höfer. 1991. Mechanisms of acid extrusion in yeast. Biochim. Biophys. Acta 1071:375-395.

27. Sontag, W. 1977. A comparative kinetic study on the conversion of fluorescein diacetate to fluorescein in living cells and in vitro. Radiat. Environ. Biophys. 14:1-12

28. Thomas, J.A., R.N. Buchshaum, A. Zimniak, and E. Racker. 1979. Intracellular pH measurements in Ehrlich ascites tumor cells utilizing spectroscopic probes generated in situ. Biochemistry 18:2210-2218.

29. Waggoner, A.S. 1990. Fluorescent probes for flow cytometry, p. 209-225. In M.R. Melamed, T. Lindmo and M.L. Mendelsohn (ed.), Flow cytometry and sorting. Wiley-Liss Inc., New York, USA.

30. Warth, A.D. 1989. Relationships among cell size, membrane permeability, and preservative resistance in yeast species. Appl. Environ. Microbiol. 55:2995-2999.

31. Wheeler, G.E., and Rose A.H. 1973. Location and properties of an esterase activity in Saccharomyces cerevisiae. J. Gen. Microb. 74:189-192.

32. Wittrup, K.D., and J.E. Bailey. 1989. Mathematical modeling of a single cell enzyme assay. Biotechnol. Bioeng. 35:525-532.

33. Wöhrmann, K., and P. Lange. 1980. The polymorphism of esterases in yeast (Saccharomyces cerevisiae). J. Inst. Brew. 86:174. 
Chapter 2 


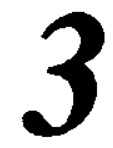

Energy-Dependent, Carrier-Mediated Extrusion of Carboxyfluorescein from Saccharomyces cerevisiae Allows Rapid Assessment of Cell Viability by Flow Cytometry

Pieter Breeuwer, Jean-Louis Drocourt, Frank M. Rombouts, and Tjakko Abee.

This chapter was published in Applied and Environmental Microbiology 60:1467-1472. (1994) 


\begin{abstract}
Carboxyfluorescein diacetate is a non-fluorescent compound which can be used in combination with flow cytometry for vital staining of yeasts and bacteria. The basis of this method is the assumption that, once inside the cell, carboxyfluorescein diacetate is hydrolyzed by non-specific esterases to produce the fluorescent carboxyfluorescein (cF). $\mathrm{cF}$ is retained by cells with intact membranes (viable cells) and lost by cells with damaged membranes. In this report, we show that Saccharomyces cerevisiae extrudes $\mathrm{cF}$ in an energy-dependent manner. This efflux was studied in detail, and several indications that a transport system is involved were found. Efflux of $\mathrm{cF}$ was stimulated by the addition of glucose and displayed Michaelis-Menten kinetics. A $\mathrm{K}_{\mathrm{m}}$ for $\mathrm{cF}$ transport of $0.25 \mathrm{mM}$ could be determined. The transport of $\mathrm{cF}$ was inhibited by the plasma membrane $\mathrm{H}^{+}$-ATPase inhibitors $N, N^{\prime}$-dicyclohexyl-carbodiimide and diethylstilbestrol and by high concentrations of tetraphenylphosphonium ions. These treatments resulted in a dissipation of the proton motive force, whereas the intracellular ATP concentration remained high. Transport of $\mathrm{cF}$ is therefore most probably driven by the membrane potential and/or the $\mathrm{pH}$ gradient. The viability of $S$. cerevisiae was determined by a two-step procedure consisting of loading the cells with $\mathrm{cF}$ followed by incubation at $40^{\circ} \mathrm{C}$ in the presence of glucose. Subsequently, the fluorescence intensity of the cells was analyzed by flow cytometry. The efflux experiments showed an excellent correlation between the viability of $S$. cerevisiae cells and the ability to translocate $c F$. This method should prove of general utility for the rapid assessment of yeast vitality and viability.
\end{abstract}

\title{
Introduction
}

Traditional enumeration of viable micro-organisms by the plate count method takes several days. Hence, there is an interest in developing more rapid methods. In 1966, Rotman and Papermaster (20) reported the use of non-fluorescent precursor molecules which were taken up by mammalian cells and cleaved by intracellular enzymes to give a fluorescent product. This staining by fluorescein diacetate or related compounds is principally based on the assumption that only cells which have an intact plasma membrane are able to accumulate the fluorescent probe. Subsequently this concept has been used by several others for the determination of viable micro-organisms, yeasts, lymphocytes and other eucaryotic cells $(4-7,26,28)$. The fluorescence intensity of the individual cells can be measured by flow cytometry.

As clearly outlined by Shapiro (23), the criterion of membrane integrity for viability is only limited. The distinction between stained cells (which are considered viable) and cells which are not stained (considered non-viable) is not absolute. Cells which have lost the ability to reproduce but still have an intact membrane are nevertheless stained. In addition, the efflux 
of probe may frustrate the fluorescent viability staining resulting in a decrease or loss of signal in viable cells. This excretion may be an energy-dependent process, as was shown for efflux of fluorescein and fluorescein derivatives in Lactococcus lactis, Hela cells and epithelial cells $(1,15,16,18)$.

At present, no satisfactory rapid method for the determination of yeast viability (defined as the ability of the yeast cell to reproduce) exists. The methylene blue exclusion test is used most often but has the disadvantage that it overestimates the viability (5). The use of intracellular glycogen or trehalose contents as an indication of viability is also limited since no unique correlation between the intracellular content of these compounds and the viability was found (25).

In this paper, we provide evidence that Saccharomyces cerevisiae extrudes $\mathrm{cF}$ in an energydependent manner, most likely via a secondary transport system. The efflux of $\mathrm{cF}$ from the cells was analyzed by flow cytometry, which provides a rapid cell-by-cell analysis. The implications of the accumulation and efflux of $\mathrm{cF}$ for the detection of yeasts and the rapid assessment of yeast viability and vitality (defined as the capacity of the yeasts to initiate metabolism rapidly after transfer from a nutrient-poor to a nutrient-rich environment (11)) by use of flow cytometry are discussed.

\section{Materials and Methods}

Abbreviations. The following abbreviations are used in this report: $\mathrm{cF}$, carboxyfluorescein; $\mathrm{cFDA}$, carboxyfluorescein diacetate; $\mathrm{TPP}^{+}$, tetraphenylphosphonium ion; DMSO, dimethyl sulfoxide; DCCD, $N, N$-dicyclohexylcarbodiimide;HEPES, $N$-[2-Hydroxyethyl]piperazine- $N$-[2-ethanesulfonicacid];DNP, 2,4-dinitropenol; $t_{1 / 2}$, time needed for $50 \%$ efflux of original probe content.

Organism and growth conditions. $S$. cerevisiae L115 was grown aerobically in Sabouraud broth at $30^{\circ} \mathrm{C}$. Cells were harvested at the end of the exponential growth phase at a viable cell concentration of approx. $3 \cdot 10^{7}$ per $\mathrm{ml}$ of broth.

Loading of cells with $\mathbf{c F}$. Washed cells were resuspended in Mcllvaine buffer, which is composed of citric acid $(100 \mathrm{mM})$ and di-sodium hydrogen phosphate dihydrate $(200 \mathrm{mM})$ set to the desired $\mathrm{pH}(\mathrm{pH}$ 4.0 , unless indicated otherwise). cFDA $(10 \mathrm{mg} / \mathrm{ml}$ in acetone) was added to a final concentration of 43 $\mu \mathrm{M}$ unless indicated otherwise. The suspension was incubated $15 \mathrm{~min}$ at $40^{\circ} \mathrm{C}$ and placed on ice until further use.

Measurement of cF efflux. cF-loaded cells were washed twice and resuspended in ice-cold McIlvaine buffer, $\mathrm{pH} 4.0$ or 7.3 . At time zero, the tubes were placed in a waterbath at $30^{\circ} \mathrm{C}$, and samples $(200 \mu \mathrm{l})$ were withdrawn and put in Eppendorf tubes, which were placed in ice. Cells were spun down immediately for $3 \mathrm{~min}$ in an Eppendorf centrifuge, and $150 \mu \mathrm{l}$ of the supernatant was carefully pipetted off and diluted with $750 \mu \mathrm{l}$ McIlvaine buffer $\mathrm{pH} 7.3$. Inhibitor studies were performed as described in the legends to the figures. McIlvaine buffer was replaced by a Na-HEPES buffer in experiments with the phosphate analog vanadate. Fluorescence was measured at excitation and emission wavelengths of 490 and $515 \mathrm{~nm}$, respectively (at 4-nm slid width), in a Jobin Yvon JY3D spectrofluorometer supplied with 
a $200 \mathrm{~W}$ HBO mercury arc light source. Measurements were performed in the linear part of the calibration curve.

The intracellular $\mathrm{cF}$ concentration at the beginning of the experiment (time zero) was determined in duplicate by permeabilizing the cell suspension in McIlvaine buffer $(\mathrm{pH} 7.3)$ with $0.1 \%$ Triton $\mathrm{X}-100$ $+0.5 \mathrm{M} \mathrm{KCl}$ in combination with freezing and thawing (14). The cells were first washed either by repeated centrifugation and resuspension, or by filtration on $0.4-\mu \mathrm{m}$-pore-size (diameter $25 \mathrm{~mm}$ ) polycarbonate membrane filters (Nucleopore) and subsequent washing with several volumes of ice-cold buffer. The permeabilized cells were centrifuged and the $\mathrm{cF}$ concentration in the supernatant was determined as described above.

Flow cytometric analysis. Analysis of the fluorescence intensity of individual cells was performed by flow cytometry. $S$. cerevisiae suspensions were diluted 10 -fold in Mcllvaine buffer (pH 4.0 or 7.3; final cell concentration approximately $10^{7}$ per $\left.\mathrm{ml}\right)$ in the absence or presence of glucose $(10 \mathrm{mM})$. At time zero the samples were placed in a waterbath at $40^{\circ} \mathrm{C}$. Time series were made by taking $60 \mu \mathrm{l}$ aliquots which were diluted into $3 \mathrm{ml}$ of McIlvaine buffer (pH 7.3) and immediately analyzed with a flow cytometer (ChemFlow flow cytometer; Chemunex S.A., Maisons Alfort, France). The fluidic system was composed of a closed laminar flow with a maximal flow rate of $0.4 \mathrm{ml}$ per min. For the flow cytometric enumeration, a sample volume of $0.20 \mathrm{ml}$ was analyzed. The maximal concentration of fluorescent particles which could be measured by the ChemFlow flow cytometer was approx. $10^{5}$ particles per ml. The instrument was supplied with a $100 \mathrm{~W}$ HBO mercury arc light source. The excitation wavelength was set between 450 and $490 \mathrm{~nm}$ by use of 2 bandpass filters. The emission wavelength of $515 \mathrm{~nm}$ was selected by a dichroic filter of $500 \mathrm{~nm}$ (eliminating signals of less than $500 \mathrm{~nm}$ ) and an interferential filter (FI 515) at $515 \mathrm{~nm}$.

The $\mathrm{Y}$-axis of the histograms corresponds to the number of fluorescent particles. The $\mathrm{X}$-axis is divided into channels 0 to 255 relative to the fluorescence intensity of the particles. A logarithmic amplification ( $\log 1$ mode) of the incoming signal was applied to measure a wider dynamic range of signals in one histogram. The shift of the histograms was expressed by the change of the mean fluorescence of the fluorescent population. The instrument was calibrated at channel 230 in $\log 1$ mode with standard $2.355 \mu \mathrm{m}$, coumarin-6 labelled fluorescent polystyrene latex spheres (Molecular Probes Inc. Eugene, Oregon, USA.).

Determination of the proton pump activity of $S$. cerevisiae. A suspension of approx. $5 \times 10^{7}$ cells per $\mathrm{ml}$ was preincubated for $15 \mathrm{~min}$ at $40^{\circ} \mathrm{C}$ in Mcllvaine buffer (pH 4.0), washed, and then resuspended in $5 \mathrm{mM} \mathrm{Na-HEPES} \mathrm{buffer} \mathrm{(pH} \mathrm{7.3).} \mathrm{Cell} \mathrm{suspensions} \mathrm{were} \mathrm{stirred} \mathrm{in} \mathrm{a} \mathrm{water-jacketed}$ vessel $\left(35^{\circ} \mathrm{C}\right)$, and the $\mathrm{pH}$ was recorded continuously with a $\mathrm{pH}$ electrode. The proton pump activity (in $\mathrm{nmol} \mathrm{H}^{+}$per min per $\mathrm{mg}$ of protein) was determined from the slope directly after the addition of glucose $(10 \mathrm{mM})$. Inhibitor studies were performed by incubating the cells with vanadate $(1 \mathrm{mM})$, DES $(150 \mu \mathrm{M})$, or DCCD $(200 \mu \mathrm{M})$, whereafter proton pumping was measured upon the addition of glucose.

Measurement of the intracellular ATP concentration. The ATP concentration was measured in a Lumac/3M biocounter $M 2010$, using the Lumac luciferin-luciferase enzyme assay. The samples $(20 \mu l)$ were mixed with Dimethyl sulfoxyde $(80 \mu \mathrm{l})$ and diluted with of $5 \mathrm{ml}$ nanopure filtered water. The luciferin-luciferase mixture $(100 \mu \mathrm{l})$ was added to $200 \mu \mathrm{l}$ of this diluted sample, after which the luminescence was measured.

Chemicals. cF, DES, sodium orthovanadate, DNP, benzoic acid, TPP ${ }^{+}$, Dimethyl sulfoxyde, and DCCD were obtained from Sigma Chemical Co., St. Louis, MO, USA. cFDA was obtained from 
Boehringer, Mannheim, Germany. Lumit-PM (luciferin-luciferase mixture) and Lumit buffer were obtained from Perstop Analytical, Oud-Beyerland, The Netherlands.

\section{Results}

Accumulation and retention of $\mathrm{cF}$ in $S$. cerevisiae. $S$. cerevisiae cells were loaded with $\mathrm{cF}$ at $\mathrm{pH} \mathrm{4}$, and subsequently the retention of $\mathrm{cF}$ was studied under different conditions. $\mathrm{cF}$ was well retained in cells stored on ice, but at $30^{\circ} \mathrm{C}$ a rapid efflux of $\mathrm{cF}$ occurred (Fig. 1). This efflux was $\mathrm{pH}$ dependent and more rapid at lower $\mathrm{pH}$. At $\mathrm{pH} 4$ and 7.3 , the $\mathrm{t}_{1 / 2}$ values were approximately 7 and $21 \mathrm{~min}$, respectively. Addition of glucose to the cells resulted in a significant stimulation of the $\mathrm{cF}$ efflux at $\mathrm{pH} 7.3\left(\mathrm{t}_{1 / 2}, 10 \mathrm{~min}\right)$, while efflux at $\mathrm{pH} 4.0$ was only slightly stimulated $\left(\mathrm{t}_{1 / 2}, 6 \mathrm{~min}\right)$. $\mathrm{cF}$ efflux was also stimulated in the presence of fructose and mannose, while galactose and glycerol had no effect. Stimulation of $\mathrm{cF}$ efflux in the presence of metabolizable substrates suggests that $\mathrm{cF}$ extrusion is an energy-dependent process.

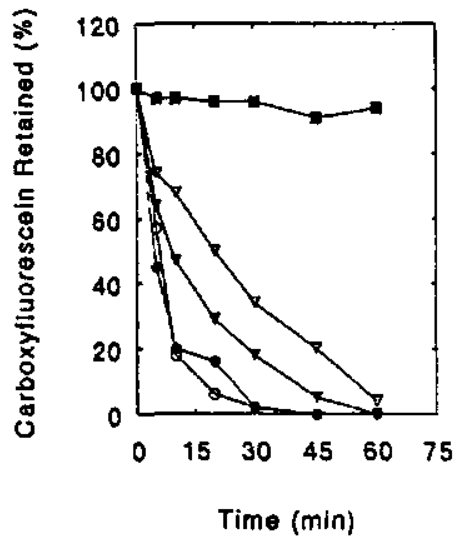

FIG. 1. Retention of $\mathrm{cF}$ in $S$. cerevisiae $\mathrm{L} 115$ under different conditions. The cells were loaded with $\mathrm{cF}$ by incubation at $40^{\circ} \mathrm{C}$ with $0.22 \mathrm{mM} \mathrm{cFDA}$. The $\mathrm{cF}$ efflux at $\mathrm{pH} 7.3$ was measured at $0^{\circ} \mathrm{C}(\square)$ and at $30^{\circ} \mathrm{C}$ in the absence $(\nabla)$ and presence $(\nabla)$ of glucose $(10 \mathrm{mM})$. $\mathrm{cF}$ efflux at $\mathrm{pH} 4.0$ was measured at $30^{\circ} \mathrm{C}$ in the absence $(\mathrm{O})$ and presence $(\Theta)$ of glucose $(10 \mathrm{mM})$.

Efflux of cF against a concentration gradient. Further evidence for the involvement of metabolic energy in $\mathrm{cF}$ extrusion can be obtained by studying $\mathrm{cF}$ efflux in the presence of a high extracellular $\mathrm{cF}$ concentration $(1 \mathrm{mM})$. The initial intracellular $\mathrm{cF}$ concentration was approx. $0.5 \mathrm{mM}$. In the absence of glucose, efflux occurred at a low rate, while in the 
presence of glucose as an energy source, efflux was observed to proceed against a concentration gradient (data not shown). The results suggest that $\mathrm{cF}$ efflux in $S$. cerevisiae is mediated by an active transport system.

Kinetics of $\mathbf{c F}$ efflux. Cells were loaded with different amounts of $\mathrm{cF}$ and the initial rate of efflux was determined (Fig. 2). The $\mathrm{cF}$ efflux was saturable at high internal concentrations and obeyed Michaelis-Menten kinetics. The results were analyzed in an Eadie-Hofstee plot and a $\mathrm{K}_{\mathrm{m}}$ of $0.25 \mathrm{mM}$ for $\mathrm{cF}$ transport was determined, which further supports the previous observations (see above) and provides strong evidence that $\mathrm{cF}$ translocation occurs via a carrier-mediated process.

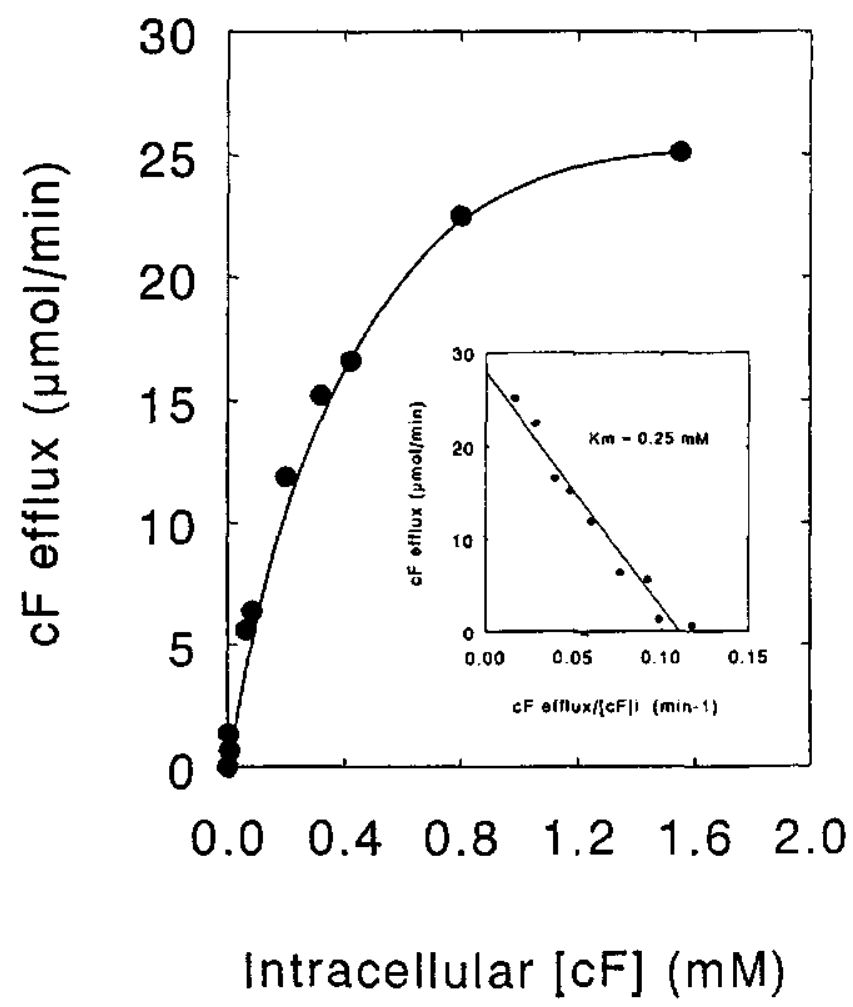

FIG. 2. Effect of intracellular $\mathrm{cF}$ concentration on initial rate of $\mathrm{cF}$ efflux. $S$. cerevisiae $\mathrm{L} 115$ cells were loaded with $\mathrm{cF}$ by incubation at $40^{\circ} \mathrm{C}$ with different concentrations of cFDA in McIlvaine buffer (pH 4). The cells were washed and resuspended in Mcllvaine buffer ( $\mathrm{pH} 7.3$ ), and $\mathrm{cF}$ efflux was measured at $30^{\circ} \mathrm{C}$ in the presence of glucose $(10 \mathrm{mM})$. 
Temperature dependence of $\mathrm{cF}$ efflux. The rate of $\mathrm{cF}$ efflux from cells is dependent on the temperature (Fig. 1). At initial intracellular concentrations of $\mathrm{cF}$ considerably greater than the determined $\mathrm{k}_{\mathrm{m}}$, a zero-order efflux rate constant could be determined. The rate constants were plotted in an Arrhenius plot (Fig. 3), and from the slope an activation energy of $50 \mathrm{~kJ}$ per mol was calculated, indicative of a carrier-mediated process.

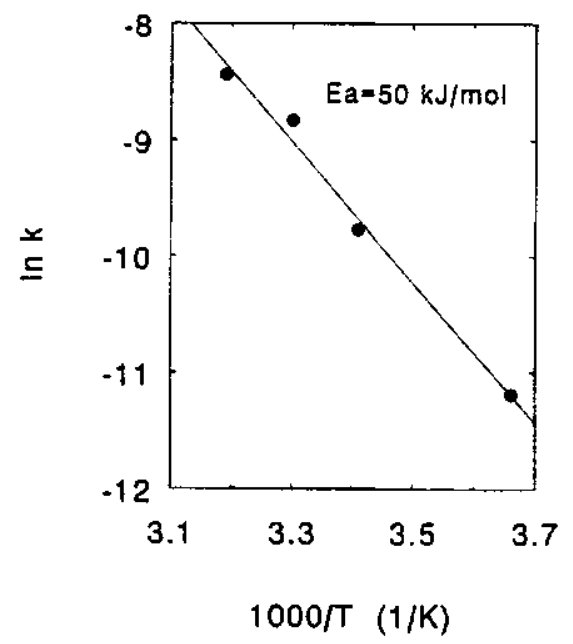

FIG. 3. Arrhenius plot of $\mathrm{cF}$ efflux from $S$. cerevisiae. Loading of cells with $\mathrm{cF}$ and subsequent analysis of $\mathrm{cF}$ efflux at different temperatures are described in Materials and Methods. The activation energy was calculated from the slope of the fitted line.

Inhibition of cF efflux. To study the mechanism of transport, the effect of various compounds on $\mathrm{cF}$ efflux was investigated.

(i) Effect of DNP and benzoic acid. Additional arguments for energy-dependent efflux can be obtained by inhibition of $\mathrm{cF}$ efflux in deenergized cells. At low external $\mathrm{pH}$, yeasts can be (partly) depleted of ATP with protonophores or weak acids $(22,30,31)$. Cells were preincubated with DNP $(1 \mathrm{mM})$ or benzoic acid $(10 \mathrm{mM})$ for $20 \mathrm{~min}$ at $\mathrm{pH} 4.0$ and $40^{\circ} \mathrm{C}$ prior to loading with $\mathrm{cF}$. After washing, the cells were resuspended in buffer ( $\mathrm{pH} 7.3$ ) and efflux was analyzed (Fig. 4). cF efflux was severely reduced in cells treated with DNP or benzoic acid. Control cells had lost approximately $100 \%$ of the original amount of $\mathrm{cF}$ in $60 \mathrm{~min}$, while 14 and $58 \%$ was excreted from cells treated with DNP or benzoic acid, respectively. Apparently, under the conditions used, endogenous energy was more efficiently dissipated with DNP than with benzoic acid. In additional experiments, $\mathrm{cF}$ efflux was studied in the presence of glucose, and 


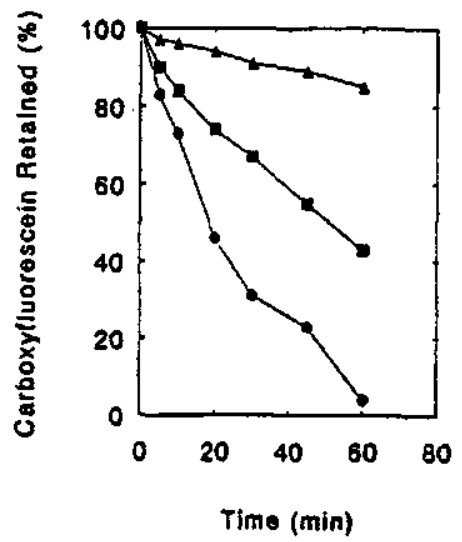

FIG. 4. Effect of benzoic acid and DNP on $\mathrm{cF}$ efflux in S. cerevisiae L115. Cells were preincubated for 20 minutes at $40^{\circ} \mathrm{C}$ in Mcllvaine buffer ( $\mathrm{pH} \mathrm{4}$ ) in the absence (O) or the presence of $1 \mathrm{mM}$ DNP (4) or $10 \mathrm{mM}$ benzoic acid $(\square)$. After washing, the cells were loaded with $\mathrm{cF}$ by incubation at $40^{\circ} \mathrm{C}$ with $0.043 \mathrm{mM}$ cFDA in Mcllvaine buffer (pH 4), washed and resuspended in McIlvaine buffer pH (7.3). cF efflux was determined at $30^{\circ} \mathrm{C}$ in the absence of glucose.

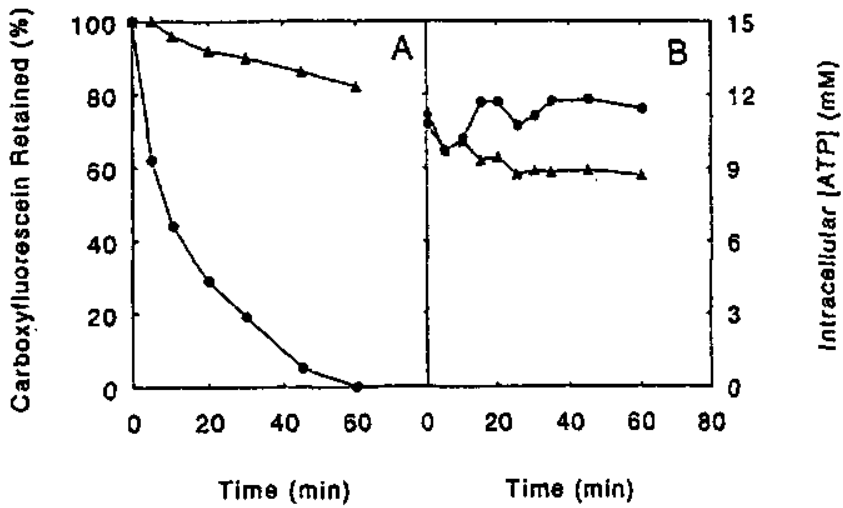

FIG. 5. Effect of $\mathrm{TPP}^{+}(10 \mathrm{mM})$ on $\mathrm{cF}$ efflux (A) and intracellular ATP concentrations (B) in $S$. cerevisiae L115. Cells were loaded with $\mathrm{cF}$ at $40^{\circ} \mathrm{C}$ with $0.043 \mathrm{mM} \mathrm{cFDA}$ in Mcllvaine buffer ( $\mathrm{pH}$ 4.0), washed and resuspended in Mcllvaine buffer ( $\mathrm{pH} 7.3$ ). $\mathrm{cF}$ efflux and intracellular ATP concentrations were determined at $30^{\circ} \mathrm{C}$ in glucose energized cells in the absence ( $)$ and presence of (৬) $10 \mathrm{mM} \mathrm{TPP}$. 
now both control cells and DNP-benzoic acid-treated cells extruded $\mathrm{cF}$ at a higher rate (data not shown). These results support the presence of an energy-dependent $\mathrm{cF}$ extrusion system. (ii) Effect of $\mathrm{TPP}^{+}$. Is $\mathrm{cF}$ transport mediated by an ATP-dependent transport system or by a secondary transport system which is driven by the proton motive force? Attempts to measure the membrane potential with low concentrations of the lipophilic cation TPP $^{+}$(final concentration, $4 \mu \mathrm{M}$ ) failed, which might be due to a low uptake rate of $\mathrm{TPP}^{+}(3)$. However, the membrane potential in yeasts can be abolished by adding high concentrations (e.g. $10 \mathrm{mM}$ ) of $\mathrm{TPP}^{+}(10)$. Nigericin and valinomycin are not very effective on the plasma membrane of yeasts (12), and we therefore decided to use $\mathrm{TPP}^{+}$to dissipate the membrane potential in $S$. cerevisiae. cF efflux from cells in the presence of glucose was almost completely inhibited when $\mathrm{TPP}^{+}$was added to a final concentration of $10 \mathrm{mM}$ (Fig. 5A). However, the intracellular ATP levels were only slightly reduced under these conditions and were very similar to those in the control cells (Fig. 5B). These results suggest that $\mathrm{cF}$ efflux is driven by the proton motive force.

(iii) Effect of ATPase inhibitors. Further arguments for the involvement of the proton motive force in carrier-mediated $\mathrm{cF}$ efflux were obtained by investigating the effect of plasma membrane $\mathrm{H}^{+}$-ATPase inhibitors. Experiments in cells and in isolated yeast plasma membranes have shown that the $\mathrm{H}^{+}$-extruding ATPase is inhibited by vanadate, DES, and DCCD $(9,21,24)$. The effect of these compounds on proton pumping activities in glucose energized cells of $S$. cerevisiae is shown in Fig. 6. In the presence of glucose only $(10 \mathrm{mM})$, the initial $\mathrm{H}^{+}$extrusion was approximately $540 \mathrm{nmol}$ of $\mathrm{H}^{+} / \mathrm{min} / \mathrm{mg}$ of protein. In the presence of DCCD $(200 \mu \mathrm{M})$ or DES $(150 \mu \mathrm{M}), \mathrm{H}^{+}$pumping was reduced to 330 and $122 \mathrm{nmol} \mathrm{H} / \mathrm{min} / \mathrm{mg}$ protein, respectively (40 and $80 \%$ inhibition with DCCD and DES, respectively). In the presence of the phosphate analog vanadate $(24) \mathrm{H}^{+}$extrusion was only slightly affected (Fig. 6). Longer pre-incubation of the cells (45 minutes) with DCCD or vanadate did not result in increased inhibitory effects.

The inhibition of the proton pump was correlated with the inhibition of $\mathrm{cF}$ efflux. In energized cells, DES strongly inhibited the efflux of $\mathrm{cF}$, while DCCD showed a smaller inhibitory effect (Fig. 7A). The intracellular ATP concentration was not much influenced by DES or DCCD (Fig. 7B). Vanadate $(1 \mathrm{mM}$ ) did not have an effect on cF efflux (data not shown), which is in line with the previous observation that it did not affect $\mathrm{H}^{+}$-pumping (Fig. 6). These results show that dissipation of the proton motive force or inhibition of the proton motive force generation by the plasma membrane $\mathrm{H}^{+}$-ATPase result in a strong reduction of $\mathrm{cF}$ efflux. Since under these conditions the intracellular ATP concentrations remained high (Fig. 6B and 7B), it is unlikely that $\mathrm{cF}$ is extruded via an ATP-dependent transport system. The results favor a secondary transport system for $\mathrm{cF}$.

Flow cytometric analysis of the efflux. The accumulation of $\mathrm{cF}$ in yeast cells is principally based on membrane integrity. However, "vital" cells translocate $\mathrm{cF}$ to the external environment (see above). A relative simple method to determine efflux of fluorescent probes from individual 


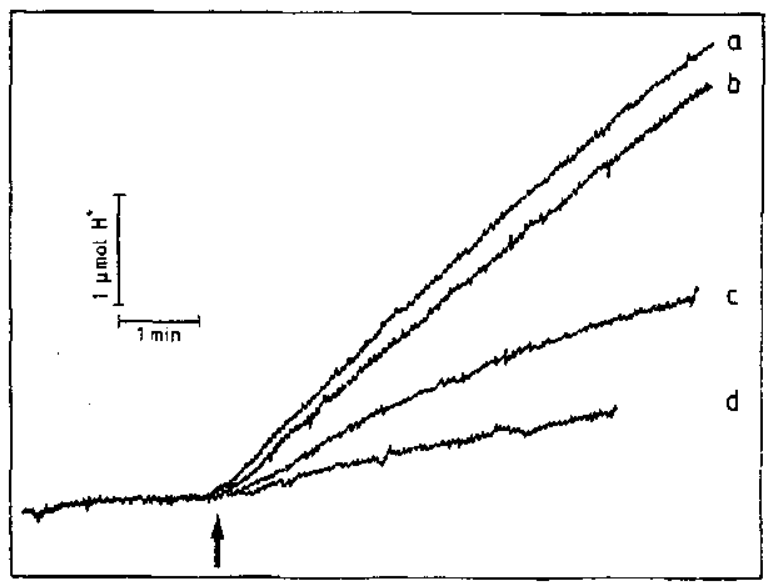

FIG 6. Effect of plasma membrane ATPase inhibitors on $\mathrm{H}^{+}$pumping capacity in $S$. cerevisiae $\mathrm{L} 115$. Cells were loaded with $\mathrm{cF}$ by incubation with $0.043 \mathrm{mM}$ cFDA in McIlvaine buffer (pH 4.0 ) at $40^{\circ} \mathrm{C}$. Cells were washed and resuspended in $5 \mathrm{mM}$ Na-HEPES buffer $\mathrm{pH} 7.3$. Glucose $(10 \mathrm{mM})$ was added at the time indicated by the arrow. The assay was performed at $35^{\circ} \mathrm{C}$. The following additions were made: a, none; b, vanadate $(1 \mathrm{mM})$; c, DCCD $(200 \mu \mathrm{M}) ; \mathrm{d}, \mathrm{DES}(150 \mu \mathrm{M})$.

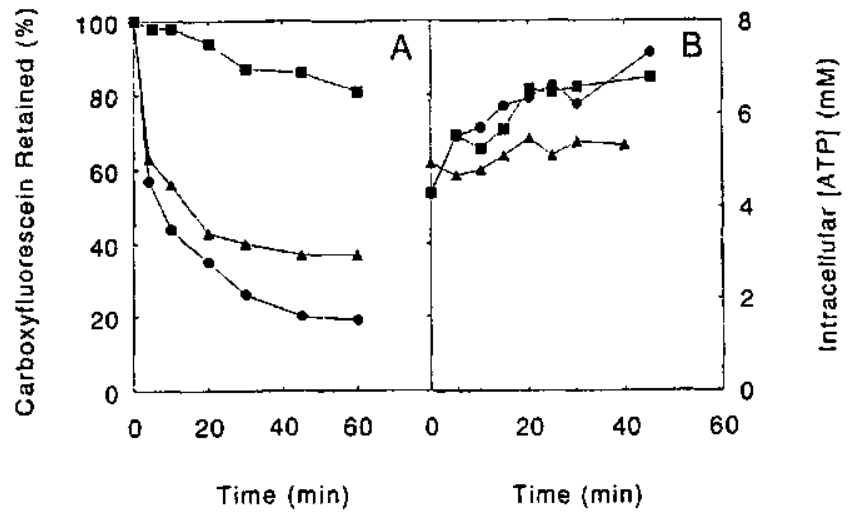

FIG 7. Effect of plasma membrane ATPase inhibitors on $\mathrm{cF}$ efflux (A) and intracellular ATP concentrations (B) in $S$. cerevisiae L115. Cells were loaded with $\mathrm{cF}$ at $40^{\circ} \mathrm{C}$ with $0.043 \mathrm{mM} \mathrm{cFDA}$ in

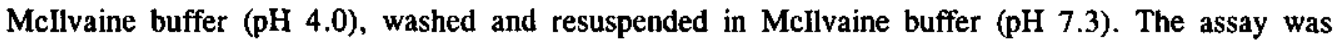
performed at $30^{\circ} \mathrm{C}$ in the presence of glucose $(10 \mathrm{mM})$. The following additions were made: (ब), none; (ם) DES $(150 \mu \mathrm{M}) ;(\triangleleft)$, DCCD $(100 \mu \mathrm{M})$. 
cells is flow cytometry. As illustrated in Fig. 8, the cF fluorescence of individual cells shown in the histograms was quite heterogeneous. The mean intracellular $\mathrm{cF}$ concentration of a S. cerevisiae culture loaded by using cFDA was about 0.1 to $0.4 \mathrm{mM}$.

Fig. 8A-1 shows a typical shift to the left of the histograms due to the loss of fluorescence at $40^{\circ} \mathrm{C}$ by yeast cells previously loaded with $\mathrm{cF}$. As expected from results presented above, addition of glucose caused a significant extra shift in the fluorescence intensity of the cells as a function of time (Fig. 8B-1). In a subsequent series of experiments, cF retention was analyzed in $S$. cerevisiae cells which were stressed in different ways: (i) a short incubation at high temperature $\left(1.5 \mathrm{~min}\right.$ at $\left.60^{\circ} \mathrm{C}\right)$; (ii) preincubation with DNP $(1 \mathrm{mM})$; or (iii) preincubation with benzoic acid $(10 \mathrm{mM})$. The histograms show that neither the initial number of fluorescent

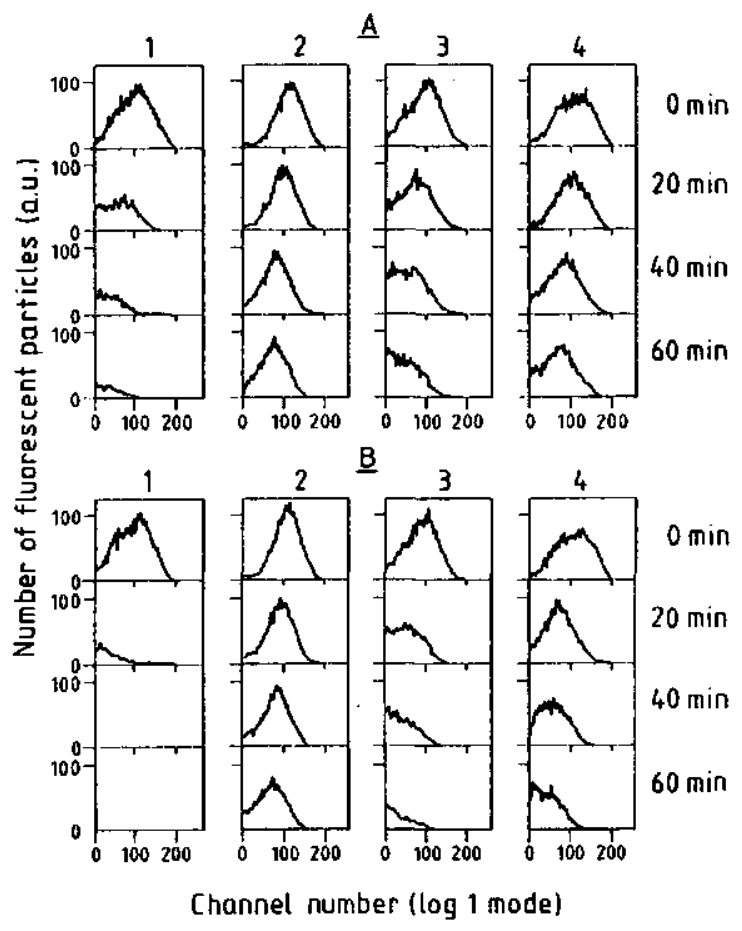

FIG. 8. Histograms of an $S$. cerevisiae population. Cells were loaded with $0.043 \mathrm{mM}$ cFDA at $40^{\circ} \mathrm{C}$. Subsequently, loss of fluorescence at $40^{\circ} \mathrm{C}$ after $0,20,40$ and 60 minutes was measured with a flow cytometer in non-energized cells $(A)$ and in cells energized with glucose $(10 \mathrm{mM})(B)$. Cells were pretreated as follows: 1 , no treatment; 2 , heat treatment at $60^{\circ} \mathrm{C}$ for 90 seconds; 3 , preincubation with benzoic acid $(10 \mathrm{mM})$; and 4 , preincubation with DNP $(1 \mathrm{mM})$. a.u., arbitrary units. 
particles nor the initial fluorescence intensity of $\mathrm{cF}$ loaded cells was significantly decreased (Fig. 8A). However, the decrease in viable cells as determined from the decrease in CFU after the temperature treatment of the $S$. cerevisiae suspension was more than $4 \log$ units. In these temperature-treated cells, the shift to the left of the histogram appeared to be strongly reduced (Fig. 8A-2), and upon addition of glucose no additional shift in the histogram was observed, which indicates that the cells were not vital (Fig. 8B-2). In contrast, washed cells preincubated with benzoic acid did not show any decrease in the viable plate count. The histograms showed a reduction in the shift of the histogram, indicating that the cells were stressed (Fig 8A-3). However, subsequent addition of glucose induced again a significant decrease in the fluorescence intensity, which indicates that the cells were indeed still vital. After preincubation with DNP, the cells were severely stressed and a slight decrease in viable counts was observed (data not shown). The limited shift in the absence of glucose coincides with this observation (Fig. 8A-4), but the shift upon addition of glucose indicated that the largest part of the population was still vital (Fig. 8B-4).

The extent to which a yeast population loses its fluorescence was correlated in flow cytometry experiments with yeast "viability". Viable and non-viable cells (determined by the plate count method) were mixed at different ratios. As demonstrated in Fig. 9, an excellent correlation was found between the viable counts as determined by the plate count method (counting after 5 days incubation at $30^{\circ} \mathrm{C}$ on Sabouraud agar) and the fraction of yeast cells which had lost approximately $100 \%$ of $\mathrm{cF}$ after incubation for $30 \mathrm{~min}$ at $40^{\circ} \mathrm{C}$, such that they could not longer be detected with the flow cytometer.

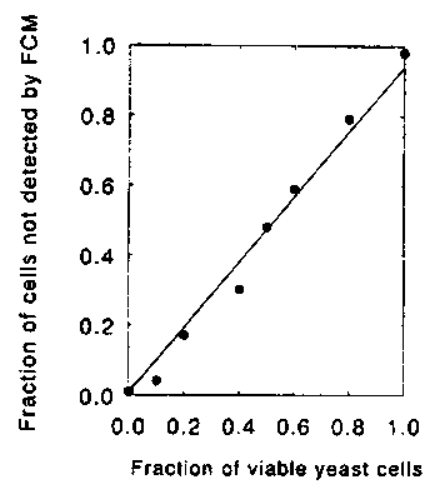

FIG. 9. Comparison of the fraction of viable cells and the fraction of $S$. cerevisiae $\mathrm{L} 115$ cells which lost all fluorescence. The viable cell counts were determined by the plate count method. The cells were loaded with $\mathrm{cF}$ by incubation with $0.043 \mathrm{mM}$ cFDA in Mcllvaine buffer (pH 4.0), washed and resuspended in McIlvaine buffer ( $\mathrm{pH} 7.3$ ). The efflux assay was performed at $40^{\circ} \mathrm{C}$ in the presence of glucose $(10 \mathrm{mM})$. The fluorescent cells were counted at time zero and after 30 minutes. FCM, flow cytometry. 


\section{Discussion}

This report shows that $S$. cerevisiae actively extrudes $\mathrm{cF}$ via a transport system. Passive transport of $\mathrm{cF}$ is not very likely since at physiological $\mathrm{pH}$ cF has predominantly a threefold negative charge and can thus be considered practically membrane impermeable (13). Furthermore it has previously been shown that $\mathrm{cF}$ leaks indeed only very slowly from artificial membrane vesicles (31). The activation energy found for $\mathrm{cF}$ efflux $(50 \mathrm{~kJ} / \mathrm{mol})$ is more in agreement with a carrier-mediated process, which is in the range of 30 to $84 \mathrm{~kJ} / \mathrm{mol}$ (16), than with passive diffusion. In addition, the $\mathrm{cF}$ efflux was saturable and obeyed Michaelis-Menten kinetics. Also, the inhibition of cF efflux by high concentrations of $\mathrm{TPP}^{+}$and by the $\mathrm{H}^{+}$ATPase inhibitors DCCD and DES indicates that $\mathrm{CF}$ is extruded in an energy-dependent manner. Since in the presence of these inhibitors the proton motive force was dissipated while the intracellular ATP concentrations remained high, the cF extrusion system is most likely correlated with the magnitude of the proton motive force and not directly with ATP or a related compound.

Is transport of $\mathrm{cF}$ driven by the membrane potential (negative inside) and/or the proton gradient $\left(\Delta \mathrm{pH}\right.$, alkaline inside)? The activation of the $\mathrm{H}^{+}$-ATPase in $S$. cerevisiae by glucose is well documented, although the mechanism is still a matter of discussion $(2,19,22,24,27)$, and results in the generation of a membrane potential (negative inside) and a pH gradient (alkaline inside). The increased rate of $\mathrm{cF}$ efflux at $\mathrm{pH} 4$ as compared to $\mathrm{pH} 7.3$ might be indicative for the involvement of the $\mathrm{pH}$ gradient $(\Delta \mathrm{pH})$. The higher efflux rate at $\mathrm{pH} 4.0$ is unlikely the result of an increased passive efflux, because addition of DNP or benzoic acid at pH 4 (inducing a decrease of the $\mathrm{pH}_{\mathrm{i}}$ ) does not stimulate but rather severely inhibits the efflux of $\mathrm{cF}$.

We suggest that there may exist in $S$. cerevisiae a transport system for anionic compounds which is most likely driven by the proton motive force, via a solute/proton-antiport or uniport mechanism. This transport system might be involved in the extrusion of (toxic) compounds from the cell (16). However, substrates for described (bacterial) multidrug resistance-like solute/proton antiport systems are not negatively, but mostly positively charged molecules (17). Extrusion of $\mathrm{cF}$ in $S$. serevisiae is not inhibited by reserpine, a typical inhibitor of multidrug resistance systems (1). The physiological role of this efflux system remains therefore to be elucidated.

$S$. cerevisiae cells can be loaded with $\mathrm{cF}$ by incubation with $\mathrm{cFDA}$. The final fluorescence intensity of the loaded cells will depend on the membrane integrity, the intracellular esterase activity, the intracellular $\mathrm{pH}$, and the loss of the fluorescent dye during the loading. Hence, the fluorescence intensity is not necessarily reflecting the viability as such. The only reasonable assumptions which can be made are that stained cells do not have severely damaged membranes and contain esterase activity. However, information about the energy status in vivo can be obtained by the efflux properties of a cell population loaded with $\mathrm{cF}$ which can easily be determined with flow cytometry. The histogram will shift to the left side of the $\mathrm{x}$-axis as result 
of the loss of intracellular fluorescence, and this phenomenon is apparently correlated to the ability of the cell to synthesize ATP and subsequently generate a proton motive force.

At $40{ }^{\circ} \mathrm{C}$, the $\mathrm{cF}$ efflux within 30 minutes from the viable yeasts was excellently correlated with the viability as determined with the plate count method (Fig. 9). However, the test conditions (loading procedure, temperature and $\mathrm{pH}$ during efflux, glucose concentration and the time interval for the measurement) play a key role in the final shift of the histogram. Hence, for each application, validation and standardization of the different parameters will be necessary.

In conclusion, we suppose that the determination of the $\mathrm{cF}$ efflux rate potentially allows a rapid and quantitative determination of the change in metabolizing capacity of a cell population upon addition of a metabolizable substrate, i.e., measurement of yeast vitality. This method should prove of general utility for the rapid assessment of yeast viability and vitality, especially for the determination of pitching yeast quality.

\section{Acknowledgements}

This work was financially supported by the E.C. mobility grant B/AGRE-910059 in the framework of the ECLAIR programme. We thank Rik van Veen for critical reading of the manuscript.

\section{References}

1. Allen, C.N., E.S. Harpur, T.J.B. Gray, N.L. Simmons, and B.H. Hirst. 1990. Efflux of bis-carboxyethylcarboxyfluorescein (BCECF) by a novel ATP-dependent transport mechanism in epithelial cells. Biochem. Biophys. Res. Commun. 172:262-267.

2. Blanpain, J.P., M. Ronjat, P. Supply, J.P. Dufour, A. Goffeau, and Y. Dupont. 1992. The yeast plasma membrane $\mathrm{H}^{+}$-ATPase. An essential change of conformation triggered by $\mathrm{H}^{+}$. J. Biol. Chem. 267:3735-3740.

3. Boxman, A.W., P.W.J.A. Barts, and G.W.F.H. Borst-Pauwels. 1982. Some characteristics of tetraphenylphosphonium uptake into $S$. cerevisiae. Biochim. Biophys. Acta. 686:13-18.

4. Bruning, J.W., M.J. Kardol, and R. Arentzen. 1980. Carboxy-fluorescein fluorochromasia assays. I. Nonradioactively labelled cell mediated lympholysis. J. Immunol. Meth.33:33-44.

5. Chilver, M.J., J. Harrison, and T.J.B. Webb. 1978. Use of immunofluorescence and viability stains in quality control. J. Amer. Soc. Brewing Chemists 36:13-18.

6. Chrzanowski, T.H., R.D. Crotty, J.G. Hubbard, and R.P. Welch. 1984. Applicability of the fluorescein diacetate method of detecting active bacteria in freshwater. Microb.Ecol.10:179-185.

7. Diaper, J.P., K. Tither, and C. Edwards. 1992. Rapid assessment of bacterial viability by flow cytometry. Appl. Microbiol. Biotechnol. 38:268-272.

8. Duro, F., and R. Serrano. 1981. Inhibition of succinate production during yeast fermentation by deenergization of the plasma membrane. Curr. Microbiol. 6:111-113.

9. Goffeau, A., and C.W. Slayman. 1981. The proton-translocating ATPase of the fungal plasma membrane. Biochim. Biophys. Acta 639:197-223.

10. Höfer, M., and F.R. Nassar. 1987. Aerobic and anaerobic uptake of sugars in Schizosaccharomyces pombe. 
J. Gen. Microbiol. 133:2163-2172.

11. Kaprelyants, A.S., and D.B. Kell. 1992. Rapid assessment of bacterial viabitity and vitality by thodamine 123 and flow cytometry. J. Appl. Bacteriol. 72:410-422.

12. Kovác, L., E. Böhmerová, and P. Butko. 1982. Ionophores and intact cells. I. Valinomycin and nigericin act preferentially on mitochondria and not on the plasma membrane of Saccharomyces cerevisiae. Biochim. Biophys. Acta 721:341-348.

13. Martin, M.M., and L. Lindqvist. 1975. The $\mathrm{pH}$ dependence of fluorescein fluorescence. J.Luminescence 10:381-390.

14. Miozzari, G.F., P. Niederberger, and R. Hütter. 1978. Permeabilization of microorganisms by triton X-100. Anal. Biochem. 90:220-233.

15. Molenaar, D., T. Abee, and W.N. Konings. 1991. Continuous measurement of the cytoplasmic pH in Lactococcus lactis with a fluorescent pH indicator. Biochim. Biophys. Acta 1115:75-83.

16. Molenaar, D., H. Bolhuis, T. Abee, B. Poolman, and W.N. Konings. 1992. The efflux of a fluorescent probe is catalyzed by an ATP-driven extrusion system in Lactococcus lactis. J. Bacteriol. 174:3118-3124.

17. Neyfakh, A.A., V.E. Bidnenko, and L.B. Chen. 1991. Efflux-mediated multidrug resistance in Bacillus subtilis: similarities and dissimilarities with the mammalian system. Proc. Natl. Acad. Sci. USA 88:4781-4785.

18. Prosperi, E. 1990. Intracellular turnover of fluorescein diacetate. Influence of membrane ionic gradients on fluorescein efflux. Histochem. J. 22:227-233.

19. Ramos, S., M. Balbín, M. Raposo, E. Valle, and L.A. Pardo. 1989. The mechanism of intracellular acidification induced by glucose in $S$. cerevisiae. J. Gen. Microbiol. 135:2413-2422.

20. Rotman, B., and B.W. Papermaster. 1966. Membrane properties of living mammalian cells as studied by enzymatic hydrolysis of fluorogenic esters. Proc. Natl. Acad. Sci. USA 55:134-141.

21. Serrano, R. 1980. Effect of ATPase inhibitors on the proton pump of respiratory-deficient yeast. Eur. J. Biochem. 105:419-424.

22. Serrano, R. 1983. In vivo activation of the yeast plasma membrane ATPase. FEBS letters 156:11-14.

23. Shapiro, H.M. 1988. Practical flow cytometry. Alan R. Liss, Inc. New York.

24. Sigler, K., and M. Höfer. 1991. Mechanisms of acid extrusion in yeast. Biochim. Biophys. Acta 1071:375395.

25. Slaughter, J.C., and T. Nomura. 1992. Intracellular glycogen and trehalose contents as predictors for yeast viability. Enzyme Microb. Technol. 14:64-67.

26. Söderström, B.E. 1977. Vital staining of fungi in pure cultures and in soil with fluorescein diacetate. Soil Biol.Biochem.9:59-63.

27. Sychrová, H., and A. Kotyk. 1985. Conditions of activation of yeast plasma membrane ATPase. FEBS letters 183:21-24.

28. Talbot, D., B.K. Shenton, A.L. Givan, G. Proud, and R.M.R. Taylor. 1987. A rapid objective method for the detection of lymphocytotoxic antibodies using flow cytometry. J. Immunol. Meth. 99:137-140.

29. Verduyn, C., E. Postma, W.A. Scheffers, and J.P. van Dijken, 1992. Effect of benzoic acid on metabolic fluxes in yeasts: a continuous-culture study on the regulation of respiration and alcoholic fermentation Yeast 8:501-517.

30. Warth, A.D. 1991. Effect of benzoic acid on glycolytic metabolite levels and intracellular pH in Saccharomyces cerevisiae. Appl. Environ. Microbiol. 57:3415-3417.

31. Weinstein, G.N., R. Blumenthal, and R.D. Klausner.1986. Carboxy-fluorescein leakage assay for lipoprotein-liposome interaction. Methods Enzymol. 128:657-668. 
Chapter 3 


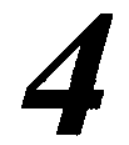

A Novel Method for Continuous Determination of the Intracellular pH in Bacteria with the Internally Conjugated Fluorescent Probe 5 (and 6-)Carboxyfluorescein Succinimidyl Ester

Pieter Breeuwer, Jean-Louis Drocourt, Frank M. Rombouts, and Tjakko Abee

This chapter was published in Applied and Environmental Microbiology 62:178-183. (1996) 


\begin{abstract}
A novel method based on the intracellular conjugation of the fluorescent probe 5 (and 6-)carboxyfluorescein succinimidyl ester (cFSE) was developed to determine the intracellular $\mathrm{pH}$ of bacteria. cFSE can be taken up by bacteria in the form of its diacetate ester 5 (and 6-)-carboxyfluorescein diacetate succinimidyl ester, which is subsequently hydrolysed by esterases to cFSE in the cytoplasm. When Lactococcus lactis cells were permeabilized with ethanol, a significant proportion of cFSE was retained in the cells, which indicated that cFSE was bound intracellularly. Unbound probe could be conveniently extruded by a short incubation of the cells in the presence of a fermentable sugar, most likely by exploiting an active transport system. Such a transport system for cFSE was identified in L. lactis, Listeria innocua and Bacillus subtilis. The intracellular $\mathrm{pH}$ in bacteria can be determined from the ratio of the fluorescence signal at the $\mathrm{pH}$ sensitive wavelength $(490 \mathrm{~nm})$ and the fluorescence signal at the $\mathrm{pH}$ insensitive wavelength $(440 \mathrm{~nm})$. This cFSE ratio method significantly reduced problems due to efflux of fluorescent probe from cells during the measurement. Moreover, the method described was successfully used to determine the intracellular $\mathrm{pH}$ in bacteria under stress conditions, such as elevated temperatures and the presence of detergents.
\end{abstract}

\title{
Introduction
}

The $\mathrm{pH}_{\mathrm{in}}$ is critical for the control of many cellular processes, such as DNA transcription, protein synthesis, and enzyme activities. To study regulation of the $\mathrm{pH}_{\mathrm{in}}$, a reliable method to measure the $\mathrm{pH}_{\text {in }}$ is of utmost importance. Currently, the most frequently used method to measure $\mathrm{pH}_{\mathrm{in}}$ in bacteria is determination of the distribution of radiolabeled weak acids or bases in combination with silicon oil centrifugation $(2,3,6,8,13,25)$. The disadvantages of this technique are the limited time resolution and the potential negative effects of weak acids on cell metabolism. Another common method is the ${ }^{31} \mathrm{P}$ nuclear magnetic resonance technique (24), but its application is limited by the very high cell densities required, the limited time response, and the expensive equipment necessary.

Application of fluorescence techniques for $\mathrm{pH}_{\text {in }}$ measurements have the advantage of a high time resolution and simplicity of use $(16,26)$. However, untill now, a significant drawback had been leakage of the probe to the external environment $(3,16,19)$, which could impair measurement by creating a high level of background. A strategy to prevent this problem is to employ more polar fluorescent compounds, such as BCECF and 8-hydroxy1,3,6-pyrene-trisulfonic acid (pyranine) $(11,21)$ which, because of their polarity, are less 
likely to leak from the cell. Such an approach is, however, hampered by the inability of bacterial cells to take up such negatively charged molecules. This problem can be avoided by incorporating fluorescent probes as (non fluorescent) acetoxymethyl or diacetyl esters $(11,26)$. These esters are membrane permeable and cleaved in the cytoplasm by esterases, which results in accumulation of the fluorescent form. Other methods which have been used to incorporate negatively charged fluorescent probes include electroporation (21) or a short acid shock (16).

Given that different bacteria (such as acidophiles, neutrophiles and alkalophiles) can exhibit a wide range of $\mathrm{pH}_{\mathrm{in}}$ values (typically from 5.6 to 9$)(2,3)$, it is impossible to employ a single $\mathrm{pH}$ probe which can cover the entire $\mathrm{pH}$ range. For general purposes, the $\mathrm{pK}_{\mathrm{a}}$ of the probe should ideally be around $\mathrm{pH} 7$. Currently, the most commonly used fluorescent probe for $\mathrm{pH}_{\mathrm{in}}$ measurements is $\mathrm{BCECF}$, which has a $\mathrm{pK}_{\mathrm{a}}$ of 6.97 (23). This derivative of fluorescein has four to five negative charges at physiological $\mathrm{pH}$, which enhances intracellular retention compared with fluorescein or carboxyfluorescein (11). It has been shown recently, however, that BCECF like other fluorescent probes may also be actively extruded from cells by transport systems $(1,5,17)$. To minimize resulting background problems, chemical elimination of extracellular probe (19) and mathematical correction of the fluorescent signal for efflux (16) have been exploited. Nevertheless, there is still an enormous demand for a simple, direct and high-time-resolution measurement of the $\mathrm{pH}_{\mathrm{in}}$ of bacteria without the need for extensive corrections.

In this study, the fluorescent probe $\mathrm{cFSE}$ was evaluated for determination of the $\mathrm{pH}_{\mathrm{in}}$ of bacteria. cFSE has previously been used to determine cell division in lymphocytes $(15,28)$ and bacteria (27), but it can potentially be applied as a $\mathrm{pH}$ probe, because its fluorescence is $\mathrm{pH}$ dependent. cFSE can be easily taken up by bacteria during incubation with its diacetate ester cFDASE. Once it is incorporated, it is thought that its succinimidyl group forms conjugates with aliphatic amines $(10,28)$. Fluorescence can be detected after intracellular esterase activity. This approach should avoid problems due to leakage or active efflux of the probe and allow accurate calibration of the fluorescence signal. The method has been successfully applied to determine the $\mathrm{pH}_{\text {in }}$ of Lactococcus lactis, Bacillus subtilis, Listeria innocua and Escherichia coli. It was also demonstrated that the $\mathrm{pH}_{\text {in }}$ of bacteria under severe stress conditions, such as elevated temperatures and the presence of detergents could be measured by the cFSE method.

\section{Materials and Methods}

Abbreviations. BCECF, 2',7'-bis-(2-carboxyethyl)-5 (and 6-)-carboxyfluorescein; cF, 5 (and 6-)carboxyfluorescein; cFDASE, 5 (and 6-)-carboxyfluorescein diacetate succinimidyl ester; cFSE, 
5 (and 6-)-carboxyfluorescein succinimidyl ester; HEPES, $N$-2-Hydroxyethylpiperazine- $N$-2-ethanesulfonic acid; Lauryl sulfobetaine, $N$-dodecyl- $N, N$-dimethyl-3-ammoniopropane sulfonate; $\mathrm{pH}_{\text {in }}$, intracellular $\mathbf{p H} ; \mathbf{p H}_{\text {out }}$, extracellular $\mathbf{p H} ; \mathrm{BSA}$, bovine serum albumin.

Organisms and growth conditions. L. lactis subsp. lactis (ATCC 19435 [the type strain]) and E. coli B104 (Chemunex S.A.) were grown overnight at $30^{\circ} \mathrm{C}$ in $\mathrm{M} 17$ broth (with $0.5 \%$ [wt/vol] lactose) and brain heart infusion broth (OXOID Ltd.), respectively. L. innocua 56 (provided by Alfred J $\phi$ rgensen laboratory, Copenhagen, Denmark) and B. subtilis (ATCC 6051 [the type strain]) were grown overnight in brain heart infusion broth at $30^{\circ} \mathrm{C}$ and peptone broth in a shaking water bath at $37^{\circ} \mathrm{C}$, respectively. The overnight cultures were diluted five times in fresh medium and incubated for an additional $3 \mathrm{~h}$ before they were harvested (at an optical density at $620 \mathrm{~nm}$ of approximately $0.6)$.

Loading of cells with fluorescent probe. Harvested cells were washed and resuspended in $50 \mathrm{mM}$ potassium HEPES buffer, $\mathrm{pH} 8.0$. Subsequently, the cells were incubated for $10 \mathrm{~min}$ at $30^{\circ} \mathrm{C}$ in the presence of $1.0 \mu \mathrm{M}$ cFDASE, washed, and resuspended in $50 \mathrm{mM}$ potassium phosphate buffer $\mathrm{pH}$ 7.0 (unless indicated otherwise). To eliminate non conjugated cFSE, glucose (final concentration, $10 \mathrm{mM}$ ) was added and the cells were incubated for an additional $30 \mathrm{~min}$ at $30^{\circ} \mathrm{C}(\mathrm{L}$. lactis was energized with lactose instead of glucose). The cells were then washed twice, resuspended in $50 \mathrm{mM}$ potassium phosphate buffer ( $\mathrm{pH} 7.0$ ), and placed on ice until required. With $E$. coli, the cFSE incorporation was accomplished by supplementing the HEPES buffer with $5 \mathrm{mM}$ EDTA and using phosphate buffer supplemented with $10 \mathrm{mM} \mathrm{MgCl}$.

Efflux of cFSE. cFSE efflux assays were performed in phosphate buffer, $\mathrm{pH} 7.0$, in the absence and presence of $10 \mathrm{mM}$ glucose (lactose in the case of $L$. lactis). At time zero, the tubes were placed in a water bath at $30^{\circ} \mathrm{C}$, and at various times, samples $(200 \mu \mathrm{l})$ were withdrawn and put in Eppendorf tubes which were placed on ice. The cells were spun down immediately for $3 \mathrm{~min}$ in an Eppendorf centrifuge, and $150 \mu \mathrm{l}$ of the supernatant was carefully pipetted off and diluted with $750 \mu \mathrm{l}$ of potassium phosphate buffer, $\mathrm{pH} 7.0$, in a 1-ml cuvette. Fluorescence was measured at excitation and emission wavelengths of 490 and $520 \mathrm{~nm}$, respectively (at $5 \mathrm{~nm}$ slit widths), in a spectrofluorometer (Perkin Elmer LS 50B, with a $50 \mathrm{~Hz}$ pulsed xenon lamp as light source). Total fluorescence (100\%) was estimated by using $150 \mu \mathrm{l}$ of uncentrifuged sample (supernatant and cells) after incubation.

Measurement of $\mathrm{pH}_{\mathrm{w}}$. Cells containing fluorescent probe were diluted to a concentration of approx. $10^{7}$ cells per $\mathrm{ml}$ in a 3-ml glass cuvette and placed in the stirred and thermostated cuvette holder of the spectrofluorometer. Fluorescence intensities were measured at excitation wavelengths of 490 and $440 \mathrm{~nm}$ by rapidly altering the monochromator between both wavelengths. The emission wavelength was $525 \mathrm{~nm}$, and the excitation and emission slit widths were 5 and $10 \mathrm{~nm}$, respectively. The 490-to-440 nm ratios were corrected for background signal due to buffer. The incubation temperature was $30^{\circ} \mathrm{C}$ (unless indicated otherwise). At the end of each assay the extracellular fluorescence signal (background) was determined by filtration of the cell suspension through a 0.22 $\mu \mathrm{m}$ pore-size membrane filter and measurement of the filtrate.

Calibration of $\mathrm{pH}_{\mathrm{m}}$. Calibration curves for $L$. lactis, $B$. subtilis and $L$. innocua were determined in buffers with $\mathrm{pH}$ values ranging from 4 to 10 . Buffers were prepared from glycine $(50 \mathrm{mM})$, citric acid $(50 \mathrm{mM}), \mathrm{Na}_{2} \mathrm{HPO}_{4} \cdot 2 \mathrm{H}_{2} \mathrm{O}(50 \mathrm{mM})$, and $\mathrm{KCl}(50 \mathrm{mM})$; the $\mathrm{pH}$ was adjusted with either $\mathrm{NaOH}$ or $\mathrm{HCl}$. The $\mathrm{pH}_{\text {in }}$ and $\mathrm{pH}_{\text {out }}$ were equilibrated by addition of valinomycin $(1 \mu \mathrm{M})$ and nigericin (1 $\mu \mathrm{M}$ ) and the ratios were determined as described above. 


\section{Results}

Effect of cFSE incorporation on cell viability. The influence of cFSE incorporation on the viability of $L$. lactis was determined by plate count (M17 agar). No reduction in the number of CFUs was observed after the protocol (cFDASE treatment followed by incubation with carbon source and washing) was carried out compared with the number of CFU found by plate counts of cell samples prior to the cFDASE treatment or after application of the protocol but with cFDASE omitted (data not shown).

Efflux of cFSE. L. lactis did not extrude cFSE in the absence of a carbon source, but upon addition of lactose $(10 \mathrm{mM})$, efflux was strongly stimulated (Fig. 1). Similarly, with $B$. subtilis and $L$. innocua, efflux in the absence of a carbon source was slow and was significantly stimulated upon addition of glucose $(10 \mathrm{mM})$, but it was slower compared with that with $L$. lactis. The percentages of probe retained in B. subtilis, L. innocua and $L$. lactis after $1-\mathrm{h}$ incubations at $30^{\circ} \mathrm{C}$ in the presence of carbon source was approximately 20,50 , and $15 \%$, respectively.

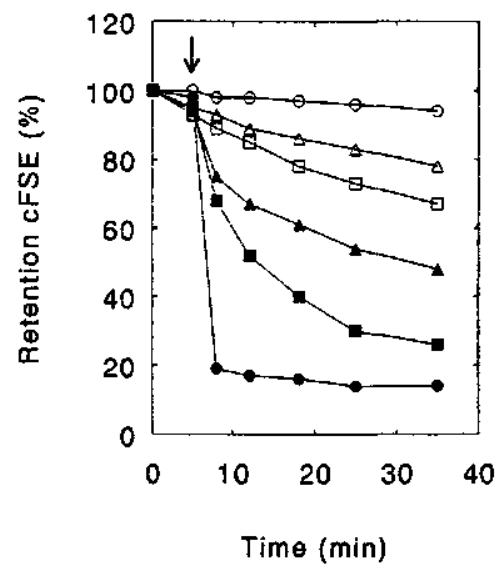

FIG. 1. Retention of cFSE in $L$. lactis (circles), B. subtilis (squares) and $L$. innocua (triangles). The cells were loaded with cFSE by incubation at $30^{\circ} \mathrm{C}$ with $1 \mu \mathrm{M}$ cFDASE. The efflux of cFSE was measured at $30^{\circ} \mathrm{C}$ in $50 \mathrm{mM}$ potassium phosphate buffer (pH 7.0) in the absence (open symbols) and presence (closed symbols) of $10 \mathrm{mM}$ glucose (B. subtilis and $L$. innocua) or lactose (L. lactis), which was added at the time indicated by the arrow.

Conjugation of cFSE and elimination of free probe. The succinimidyl group of cFSE is thought to form stable conjugates with (intracellular) aliphatic amines. In the $L$. lactis suspension containing cFSE, the relative fluorescence signal at $440 \mathrm{~nm}$ was 46.8 , of which 
3.5 was extracellular (Table 1). Upon the addition of lactose $(10 \mathrm{mM})$ or ethanol $(26 \%$, $\mathrm{vol} / \mathrm{vol}$ ) to the cuvette, most cFSE was detected in the filtrate (extracellular) after filtration of the cell suspension. Nevertheless, a significant percentage of cFSE (approx. 20\%) was not lost from the cells, and apparently conjugated. When the cells were energized with lactose $(10 \mathrm{mM})$ for $30 \mathrm{~min}$ and washed, only a small quantity of cFSE was lost from the cells after the post washing addition of lactose or ethanol. In contrast, other analogs of fluorescein, $\mathrm{cF}$ and $\mathrm{BCECF}$, were lost almost completely ( $>98 \%$ ) from previously treated cells after the 30 min incubation with lactose.

TABLE 1. Retention of cFSE, cF and BCECF in L. lactis.

\begin{tabular}{|c|c|c|c|c|c|c|}
\hline \multirow[t]{2}{*}{ Probe } & \multicolumn{3}{|c|}{$\begin{array}{l}\text { Fluorescence intensity of cells } \\
\text { loaded with fluorescent probe }\end{array}$} & \multicolumn{3}{|c|}{$\begin{array}{l}\text { Fluorescence intensity of cells loaded with } \\
\text { fluorescent probe and incubated } 30 \mathrm{~min} \text { at } \\
30^{\circ} \mathrm{C} \text { in the presence of lactose }(10 \mathrm{mM})^{a}\end{array}$} \\
\hline & Total & Intracellular & Extracellular & Total & Intracellular & Extracellular \\
\hline cFSE & 46.8 & 43.3 & 3.5 & 8.6 & 8.4 & 0.2 \\
\hline cFSE + lactose & 46.8 & 9.9 & 36.9 & 8.6 & 7.1 & 1.5 \\
\hline cFSE + ethanol (33\%) & 46.8 & 10.3 & 36.5 & 8.6 & 7.1 & 1.5 \\
\hline $\mathrm{cF}$ & 165.3 & 139.5 & 25.8 & 2.0 & 2.0 & 0.0 \\
\hline BCECF & 53.3 & 40.7 & 12.6 & 0.3 & 0.3 & 0.0 \\
\hline
\end{tabular}

" Before measurement, the cells are washed twice and resuspended in potassium phophate buffer, $\mathrm{pH}$ 7.0.

- Values are corrected for the effect of ethanol on the fluorescence signal.

Measurement of $\mathrm{pH}_{\mathrm{in}}$. The $\mathrm{pH}_{\mathrm{in}}$ was determined from the ratio of the $\mathrm{pH}$-sensitive wavelength $(490 \mathrm{~nm})$ and the $\mathrm{pH}$-insensitive wavelength $(440 \mathrm{~nm})$. The measurement of the 490-to-440 ratio was performed during a $25 \mathrm{~min}$ assay (Fig. 2). Immediately after the cFSE-stained $L$. lactis cells were washed, the fluorescence intensities at $490 \mathrm{~nm}$ and $440 \mathrm{~nm}$ decreased. This phenomenon is most likely due to photofading. At the end of each assay, the $\mathrm{pH}_{\mathrm{in}}$ and $\mathrm{pH}_{\text {out }}$ were equilibrated and the sample was filtered. When $L$. lactis cells were not energized with lactose, the unbound probe in the filtrate, which was leaked and/or exported from the cells, represented more than $90 \%$ of the total signal (Fig. 2A). However, after incubation with lactose and subsequent washing the extracellular fluorescence signal (background), which was determined at $440 \mathrm{~nm}$ after the filtration was reduced to only $11 \%$ of the total signal (Fig. 2B).

The $\mathrm{pH}_{\mathrm{in}}$ of $E$. coli was assessed after EDTA treatment to facilitate staining. A small pH gradient $\left(\mathrm{pH}_{\mathrm{in}} 7.3\right.$ to $\mathrm{pH}_{\text {out }} 7.0$ at $30^{\circ} \mathrm{C}$ ) could be observed after the addition of glucose (10 mM) (data not shown). This suggests that the vitality of this organism is decreased, since previous studies have indicated that $E$. coli has a $\mathrm{pH}_{\text {in }}$ of approx. 7.8 at an external $\mathrm{pH}$ of $7.0(3)$. 


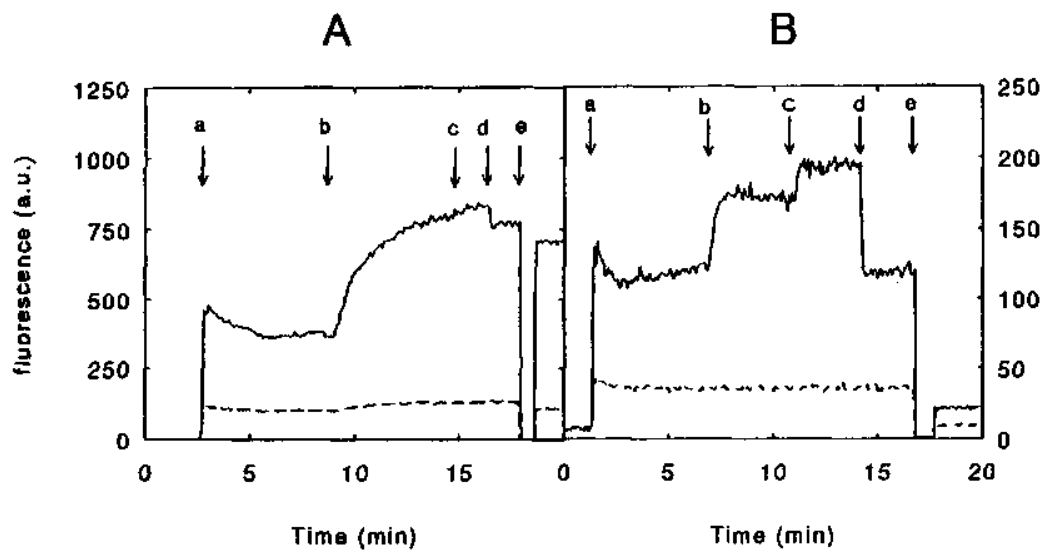

FIG. 2. Fluorescence intensity of $L$. lactis cells measured at excitations of $490 \mathrm{~nm}(\longrightarrow)$ and $440 \mathrm{~nm}$ (---). The cells were preincubated in the absence (A) or presence (B) of lactose $(10 \mathrm{mM})$. The emission wavelength was $525 \mathrm{~nm}$. The cells were loaded with CFSE as described in Materials and Methods. Measurements in the cuvette were performed at $30^{\circ} \mathrm{C}$ in $3 \mathrm{ml}$ of $50 \mathrm{mM}$ potassium phosphate buffer, $\mathrm{pH}$ 7.0. The following additions were made at the times indicated by the arrows: $\mathrm{a}$, cell suspension $(100 \mu \mathrm{l}) ; \mathrm{b}$, lactose $(10 \mathrm{mM}) ; \mathrm{c}$, valinomycin $(1 \mu \mathrm{M})$; and $\mathrm{d}$, nigericin $(1 \mu \mathrm{M})$. At arrow e the cuvette was removed for a short time from the spectrofluorometer and the filtrate was measured after filtration of the cell suspension through a disposable disc filter $(0.22 \mu \mathrm{m}$ pore size $)$. a.u., arbitrary units.

Calibration of $\mathrm{pH}_{\mathrm{in}}$. In bacteria, the $\mathrm{pK}_{\mathrm{a}}$ values derived from the 490-to-440 $\mathrm{nm}$ ratios of intracellular cFSE were increased in $\mathrm{pH}$ by about 0.6 compared with the effective $\mathrm{pK}_{\mathrm{a}}$ of 6.5 for free cFSE (Fig. 3). The ratios after the equilibration of $\mathrm{pH}_{\text {in }}$ and $\mathrm{pH}_{\text {out }}$ could not be fitted adequately with the Henderson-Hasselbalch equation $(9,12)$ but could be fitted with a 4 parameter sigmoid function $\mathrm{y}=a+b /\{1+\exp [-(x-c) / d\}]$.

The excitation spectrum of intracellular cFSE at $\mathrm{pH} 7$ after equilibration with the $\mathrm{pH}_{\text {out }}$ exhibited a red shift of about $5 \mathrm{~nm}$ (Fig. 4). Potassium glutamate $(0.5 \mathrm{M}$ ), which is present in cells at high levels, decreased the fluorescence intensity, but a red shift was not observed. The effect of some proteins on the spectrum of cFSE was also investigated. When cFSE was incubated in the presence of BSA $(0.3 \%$, vol/vol) a small red shift of the spectrum was observed and the fluorescence intensity decreased. This red shift was apparently not influenced by the $\mathrm{pH}$ of the incubation buffer (data not shown). B-Casein $(0.03 \%, \mathrm{vol} / \mathrm{vol}$ ) had no effect at all on the fluorescence spectrum of cFSE (data not shown). 


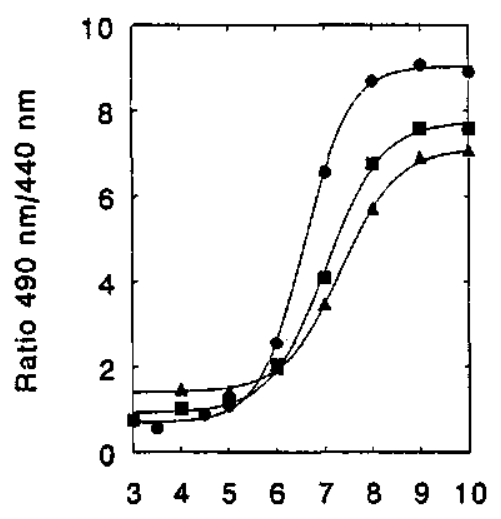

pH

FIG. 3. The relationship between the $\mathrm{pH}$ and the ratio $(490 \mathrm{~nm}$ to $440 \mathrm{~nm})$ of cFSE in buffer $(\odot)$, in B. subtilis cells ( $\square$ ), and in L. lactis cells (४). The $\mathrm{pH}_{\mathrm{in}}$ and $\mathrm{pH}_{\text {out }}$ were equilibrated by incubation with valinomycin $(1 \mu \mathrm{M})$ and nigericin $(1 \mu \mathrm{M})$.

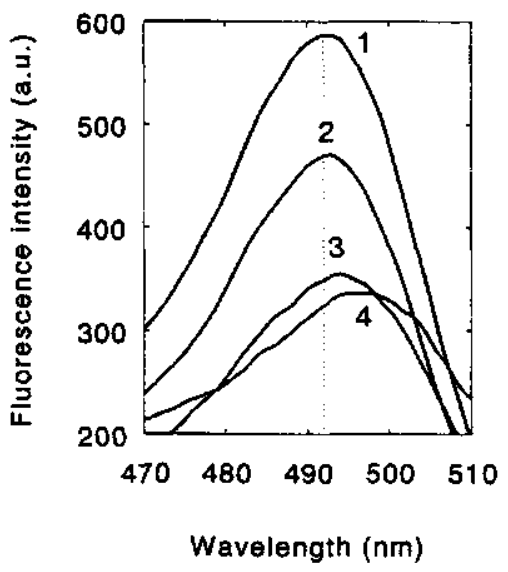

FIG. 4. Excitation spectra of cFSE in buffer (1), in the presence of $0.5 \mathrm{M}$ potassium glutamate (2) or $0.3 \% \mathrm{vol} / \mathrm{vol} \mathrm{BSA}(3)$, and when incorporated in $L$. lactis cells (4). The cFSE spectra were corrected for the autofluorescence of BSA. The measurements were performed in $50 \mathrm{mM}$ potassium phosphate buffer, $\mathrm{pH} 7.0$, at room temperature. The emission wavelength was $525 \mathrm{~nm}$. The fluorescence intensities of curves 1,2 , and 3 can not be directly compared with the fluorescence intensity of curve 4. a.u., arbitrary units 
Effect of $\mathrm{pH}_{\text {out }}$, elevated temperatures, and detergents on the $\mathrm{pH}_{\mathrm{tn}}$ of bacteria. The $\mathrm{pH}_{\mathrm{in}}$ values of energized $L$. lactis, B. subtilis and $L$. innocua were measured by the cFSE ratio method during incubation in buffers with $\mathrm{pH}$ values ranging from 5 to 9 (Fig. 5). The observed $\mathrm{pH}_{\text {in }}$ values for $B$. subtilis and $L$. innocua were remarkably similar, while that of L. lactis was lower.

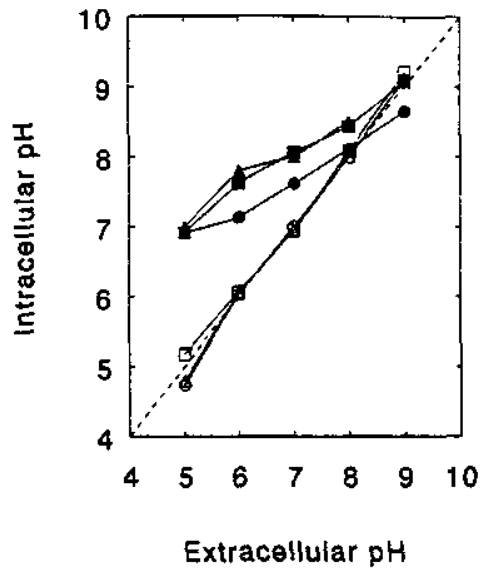

FIG. 5. Effect of $\mathrm{pH}_{\text {our }}$ on the $\mathrm{pH}_{\text {in }}$ of energized $L$. lactis (circles), B. subtilis (squares) and $L$. innocua (triangles), in the absence (solid symbols) or presence (open symbols) of valinomycin (1 $\mu \mathrm{M})$ and nigericin $(1 \mu \mathrm{M})$. Assays were performed at $30^{\circ} \mathrm{C}$. The buffers were prepared from glycine (50 $\mathrm{mM})$, citric acid $(50 \mathrm{mM}), \mathrm{Na}_{2} \mathrm{HPO}_{4} \cdot 2 \mathrm{H}_{2} \mathrm{O}(50 \mathrm{mM})$, and $\mathrm{KCl}(50 \mathrm{mM}) ; \mathrm{pH}$ was adjusted with either $\mathrm{NaOH}$ or $\mathrm{HCl}$.

Furthermore, $\mathrm{pH}_{\text {in }}$ measurements with $L$. innocua were performed at various temperatures, and these experiments showed that at $30^{\circ} \mathrm{C}$, a clear $\mathrm{pH}$ gradient (alkaline inside) of approx 1 unit was generated after the addition of potassium and glucose (Fig. 6). At $45^{\circ} \mathrm{C}$ in this organism, the $\mathrm{pH}_{\mathrm{in}}$ initially decreased, but addition of potassium and more especially glucose caused a subsequent increase in the $\mathrm{pH}_{\text {in }}$ to about 7.7. However, the cells were not able to maintain this gradient. At $53^{\circ} \mathrm{C}$, the $\mathrm{pH}_{\text {in }}$ was reduced and a reversed $\mathrm{pH}$ gradient (acid inside) resulted. Addition of potassium increased the $\mathrm{pH}_{\mathrm{in}}$ somewhat, but the $\mathrm{pH}_{\text {in }}$ still remained lower than the $\mathrm{pH}_{\text {oul }}$. Subsequent addition of glucose had no effect.

In the presence of various concentrations of detergent, the $\mathrm{pH}$ gradient (at an external $\mathrm{pH}$ of 7.0) in B. subtilis was completely dissipated by Zwittergent 3-12 and Triton X-100 at 0.025 and $0.006 \%$, respectively (Fig. 7). These results indicate that permeabilization of the cytoplasmic membrane by detergents can be determined accurately by the cFSE method. 


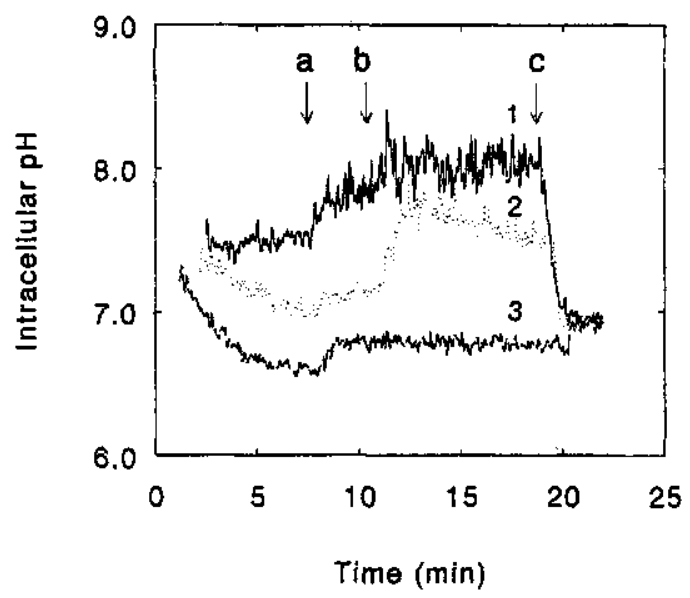

FIG. 6. Effect of temperature on the $\mathrm{pH}_{\text {in }}$ of $L$. innocua. The assays were performed at 30 (1), 45 (2), and $53^{\circ} \mathrm{C} \mathrm{(3)} \mathrm{in} 50 \mathrm{mM}$ sodium phosphate buffer, $\mathrm{pH} 7.0$. The following additions were made at the times indicated by the arrows: a, potassium chloride $(100 \mathrm{mM}) ; \mathrm{b}$, glucose $(10 \mathrm{mM})$; $\mathrm{c}$, and Zwittergent 3-12(0.1\%).

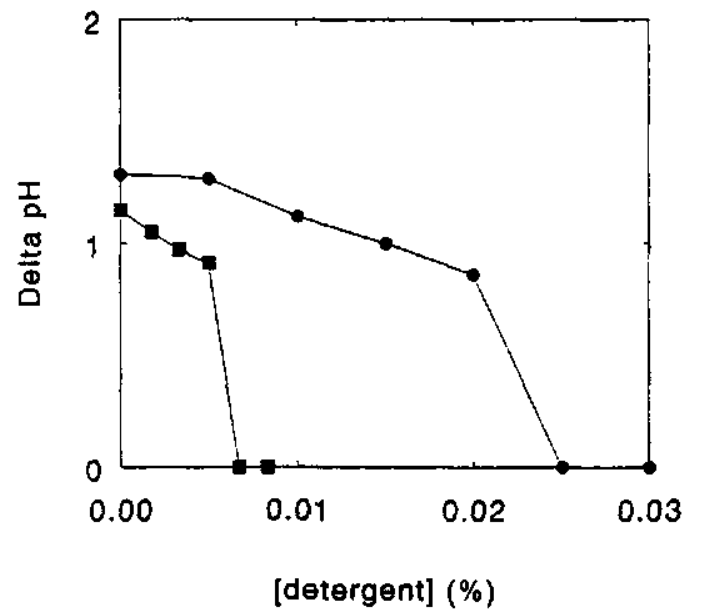

FIG. 7. $\Delta \mathrm{pH}$ of $B$. subtilis in the presence of increasing concentrations of Triton $\mathrm{X}-100(-)$ and Zwittergent 3-12 (ם). Assays were performed at $30^{\circ} \mathrm{C}$ in $50 \mathrm{mM}$ potassium phosphate buffer, $\mathrm{pH} 7$, with glucose $(10 \mathrm{mM})$. 
Method for determination of $\mathrm{pH}_{\mathrm{in}}$ with $\mathrm{cFSE}$

\section{Discussion}

This report describes a novel technique for measuring the $\mathrm{pH}_{\text {in }}$ of bacteria. This technique is based on the intracellular conjugation of cFSE in the cytoplasm of cells and then the elimination of free probe by a short incubation in the presence of a fermentable sugar. The principle advantage of such a system is that leakage of fluorescent probe is minimal, being less than $25 \%$ for cFSE after $20 \mathrm{~min}$ at $30^{\circ} \mathrm{C}$ compared with over $90 \%$ for other analogs of fluorescein, such as $\mathrm{CF}$ and BCECF. The method takes advantage of the supposed conjugation of the succinimidyl group of cFSE with the aliphatic amines of intracellular proteins (10). Significantly, incorporation and conjugation of cFSE in the cytoplasm of the cells does not affect the viability of $L$. lactis. The system is further enhanced by the ability of bacteria to eliminate unconjugated probe. Mammalian cells as well as fungi and bacteria are all known to actively extrude fluorescein and related analogs cF and BCECF $(1,5,14,17)$. In this study, three gram positive bacteria were found to efficiently extrude cFSE after addition of an appropriate carbon source. Efflux is most likely catalyzed by an ATP-driven extrusion system because efflux proceeds in the presence of ionophores valinomycin $(1 \mu \mathrm{M})$ and nigericin $(1 \mu \mathrm{M})$ (4). This system might be similar to that previously described for BCECF in $L$. lactis (17). In such gram negative bacteria as $E$. coli, the use of the cFSE method is complicated by the inability of the prefluorochrome cFDASE (molecular weight, 557) to pass the outer membrane in the gram negative cell wall. For this species, a short incubation with EDTA overcame this problem. However, the EDTA treatment may well interfere with the active efflux of unbound cFSE and generation of a significant $\mathrm{pH}$ gradient. Hence, application of this protocol for gram negative genera needs further attention.

Generally, the background levels of extracellular probe were about 10 to $20 \%$, which, while very low compared with those of other fluorescent probes, such as $\mathrm{CF}$ and BCECF, are still significant. The occurrence of this background could not be avoided, but the resulting error can be minimized by performing the calibration under identical conditions with comparable background levels.

The observed intracellular $\mathrm{pK}$ shift following the uptake of cFSE has been reported previously for other probes $(7,9,16)$, but no clear reason for this phenomenon was provided. It is unlikely that this $\mathrm{pK}$ shift resulted from high probe concentrations or a Donnan potential $(7,16)$. Recently, it was suggested that interaction of the probe with lipophilic cell compartments, such as the cytoplasmic membrane (20), was responsible for a $\mathrm{pK}$ shift with the fluorescent $\mathrm{pH}$ indicator carboxy-seminaphtorhodafluor. The quantum yield of cFSE might be affected significantly by the conjugation of the molecule. This was illustrated in vitro by the addition of potassium glutamate and BSA, both of which reduced the fluorescence intensity and/or excitation maximum. Changes in the spectral properties of cFSE inside the cells might explain why the ratio can not be fitted adequately with the 
Henderson-Hasselbalch equation. The ratio could, however, be fitted with a four parameter sigmoid function. The $\mathrm{pH}_{\mathrm{in}}$ values observed for $L$. lactis by the cFSE ratio method were comparable to the values reported by Molenaar et al. (17) and Poolman et al. (22). For other bacteria (e.g., B. subtilis and $L$. innocua), the measured $\mathrm{pH}_{\mathrm{in}}$ values were also comparable to those reported in the literature $(3,4,6)$.

The advantage of using a conjugated probe for the measurement of the $\mathrm{pH}_{\mathrm{in}}$ is most clearly illustrated by the ability to measure $\mathrm{pH}_{\mathrm{in}}$ under conditions that may permeabilize the cell envelope. Convential methods are unable to determine the $\mathrm{pH}_{\text {in }}$ under such conditions. Indeed, the cFSE approach was able to accurately show the effect of elevated temperatures on the $\mathrm{pH}$ gradient. This offers exciting new possibilities for the study of the impact of heat shock on $\mathrm{pH}$ homeostasis in bacteria. In fact, preliminary results indicated that $L$. lactis cells exposed to a heat shock could maintain a higher $\mathrm{pH}$ gradient than control cells (4). Moreover, the application of flow cytometry with fluorescent cFSE-treated cells allows the determination of the $\mathrm{pH}_{\text {in }}$ of individual cells within a population. This ability could prove useful for the study of population effects after the exposure of bacteria to various stress conditions. The approach can also be exploited in the investigation of low $\mathrm{pH}_{\mathrm{in}}$ in bacteria such as acidophiles, in which case cFSE may be replaced with 5 (and 6-)-carboxy-2',7'dichlorofluorescein succinimidyl ester, which has $\mathrm{a}_{\mathrm{pK}}$ of 3.9 in buffer and 4.9 when incorporated in bacterial cells $(4,18)$.

In conclusion, the cFSE ratio method allows sensitive and continuous measurement of the $\mathrm{pH}_{\text {in }}$ in bacteria. Leakage of fluorescent probe, which is one of the major problems with measurements with such molecules as $\mathrm{cF}$ and $\mathrm{BCECF}$, is avoided by intracellular conjugation of cFSE and subsequent elimination of free probe. It thus offers the ability to investigate the important physiological responses to $\mathrm{pH}_{\text {in }}$ variations in bacteria, even with bacteria experiencing such severe stress conditions as elevated temperatures and exposure to detergents.

\section{Acknowledgments}

This work was financially supported by the E.C. mobility grant B/AGRE-910059 in the framework of the ECLAIR program. We thank Aidan Coffey for critical reading of the manuscript.

\section{References}

1. Allen, C.N., E.S. Harpur, T.J.B. Gray, N.L. Simmons, and B.H. Hirst. 1990. Efflux of bis-carboxyethylcarboxyfluorescein (BCECF) by a novel ATP-dependent transport mechanism in epithelial cells. Biochem. Biophys. Res. Commun. 172:262-267. 
2. Bakker, E.P. 1990. The role of alkali-cation transport in energy coupling of neutrophilic and acidophilic bacteria: an assessment of methods and concepts. FEMS Microbiol. Rev. 75:319-334.

3. Booth, I.R. 1985. Regulation of cytoplasmic pH in bacteria. Microbiol. Rev. 49:359-378.

4. Breeuwer, P. Unpublished data.

5. Breeuwer, P., J.L. Drocourt, F.M. Rombouts, and T. Abee. 1994. Energy-dependent, carrier-mediated extrusion of carboxyfluorescein from Saccharomyces cerevisiae allows rapid assessment of cell viability by flow cytometry. Appl. Environ. Microbiol. 60:1467-1472.

6. Bruno, M.E.C., A. Kaiser, and T.J. Montville. 1992. Depletion of proton motive force by nisin in Listeria monocytogenes cells. Appl. Environ. Microbiol. 58:2255-2259.

7. Chaillet, J.R., and W. Boron. 1985. Intracellular calibration of a $\mathrm{pH}$-sensitive dye in isolated perfused salamander proximal tubules. J. Gen. Physiol. 86:765-794.

8. Cook, G.M., and J.M. Russell. 1994. The effect of extracellular pH and lactic acid on pH homeostasis in Lactococcus lactis and Streptococcus bovis. Curr. Microbiol. 28:165-168.

9. Graber, M.L., D.C. Dilillo, B.L. Friedman, and E. Pastoriza-Munoz. 1986. Characteristics of fluoroprobes for measuring intracellular pH. Anal. Biochem. 156:202-212.

10. Haugland, R.P. 1992. Succinimidyl esters and carboxylic acids. p. 24-33. In K.D. Larison (ed.), Handbook of fluorescent probes and research chemicals. Molecular Probes Inc., Eugene, Oreg, USA.

11. Haugland, R.P., and A. Minta. 1990. Design and application of indicator dyes, p. 1-20. In J.K. Foskett and S. Grinstein (ed.), Noninvasive techniques in cell biology. Wiley-Liss, New York, USA.

12. James-Kracke, M.R. 1992. Quick and accurate method to convert BCECF fluorescence to $\mathrm{pH}_{\mathrm{in}}$ : calibration in three different types of cell preparations. J. Cell. Physiol. 151:596-603

13. Kashket, E.R. 1985. The proton motive force in bacteria: a critical assessment of methods. Annu. Rev. Microbiol, 39:219-242.

14. Kondo, M., and M. Araie. 1994. Movement of carboxyfluorescein across the isolated rabbit iris-ciliary body. Curr. Eye Res. 13:251-255.

15. Lyons, A.B., and C.R. Parish. 1994. Determination of lymphocyte division by flow cytometry. J. Immunol. Methods 171:131-137.

16. Molenaar, D., T. Abee, and W.N. Konings. 1991. Continuous measurement of the cytoplasmic pH in Lactococcus lactis with a fluorescent $\mathrm{pH}$ indicator. Biochim. Biophys. Acta 1115:75-83.

17. Molenaar, D., H. Bolhuis, T. Abee, B. Poolman, and W.N. Konings. 1992. The efflux of a fluorescent probe is catalyzed by an ATP-driven extrusion system in Lactococcus lactis. J. Bacteriol. 174:3118-3124.

18. Nedergaard, M., S. Desai, and W. Pulsinelll. 1990. Dicarboxy-dichlorofluorescein: a new fluorescent probe for measuring acidic intraceltular $\mathrm{pH}$. Anal. Biochem. 187:109-114.

19. Noël, J., A. Tejedor, P. Vinay, and R. Laprade. 1989. Fluorescence measurement of intracellular pH on proximal tubule suspensions. Renal Physiol. Biochem. 12:371-387.

20. Opitz, N., E. Merten, and H. Acker. 1994. Evidence for redistribution-associated intracellular pK shifts of the pH sensitive fluoroprobe carboxy-SNARF-1. Eur. J. Physiof. 427:332-342.

21. Peña, A., J. Ramírez, G. Rosas, and M. Calahorra. 1995. Proton pumping and the internal pH of yeast cells, measured with pyranine introduced by electroporation. J. Bacteriol, 177:1017-1022.

22. Poolman, B., A.J.M. Driessen, and W.N. Konings. 1987. Regulation of solute transport in streptococci by external and internal $\mathrm{pH}$ values. Microbiol. Rev. 51:498-508.

23. Rink, T.J., R.Y. Tsien, and T. Pozzan. 1982. Cytoplasmic $\mathrm{pH}$ and free $\mathrm{Mg}^{2+}$ in lymphocytes. J. Cell Biol. 95:189-196.

24. Salhany, J.M., T. Yamane, R.G. Shulman, and S. Ogawa. 1975. High resolution ${ }^{31} P$ nuclear magnetic resonance studies of intact yeast cells. Proc. Natl. Acad. Sci. USA 72:4966-4970.

25. Ten Brink, B., and W.N. Konings. 1982. The electrochemical proton gradient and lactate concentration gradient in Streptococcus cremoris grown in batch culture. J. Bacteriol. 152:682-686. 
26. Thomas, J.A., R.N. Buchsbaum, A. Zimniak, and E. Racker. 1979. Intracellular pH measurements in Ehrlich ascites tumor cells utilizing spectroscopic probes generated in situ. Biochemistry 18:2210-2218.

27. Ueckert, J., P. Breeuwer, T. Abee, P. Stephens, G. Nebe von Caron, and P.F. ter Steeg. 1995. Flow cytometry applications in physiological study and detection of foodborne microorganisms. Int. J. Food Microbiol. 28:317-326.

28. Weston, S.A., and C.R. Parish. 1990. New fluorescent dyes for lymphocyte migration studies. Analysis by flow cytometry and fluorescence microscopy. J. Immunol. Methods. 133:87-97. 


\section{Nonanoic Acid, a Fungal Self-Inhibitor, Prevents Germination of Rhizopus oligosporus Sporangiospores by Dissipation of the pH Gradient}

Pieter Breeuwer, Johan C. de Reu, Jean-Louis Drocourt, Frank M. Rombouts, and Tjakko Abee.

This chapter is submitted for publication to Applied and Environmental Microbiology 


\begin{abstract}
Germination of Rhizopus oligosporus sporangiospores is characterized by swelling of the spores and subsequent emergence of germ tubes. Changes in spore morphology and alterations in intracellular $\mathrm{pH}\left(\mathrm{pH}_{\mathrm{in}}\right)$ of the sporangiospores were assessed during the germination process using flow cytometry. Sporangiospores were stained with carboxyfluorescein by incubation with carboxyfluorescein diacetate. The non-fluorescent carboxyfluorescein diacetate is passively transported into intact cells and subsequently cleaved by esterases, which results in intracellular accumulation of the fluorescent carboxyfluorescein. Given that the fluorescence of carboxyfluorescein is $\mathrm{pH}$-dependent, the $\mathrm{pH}_{\mathrm{in}}$ of the individual spores could be assessed simultaneously with spore size. For $R$. oligosporus, swelling of the sporangiospores was accompanied by an increase of $\mathrm{pH}_{\mathrm{in}}$. In the presence of nonanoic acid, a self-inhibitor produced by various fungi, increase of the $\mathrm{pH}_{\mathrm{in}}$ was prevented and swelling was inhibited. A model is proposed in which the $\mathrm{pH}_{\mathrm{in}}$ plays a crucial role in the germination of $R$. oligosporus sporangiospores.
\end{abstract}

\title{
Introduction
}

The development of fungal spores can be arbitrarily divided into several stages: formation, maturation, dormancy, after-ripening, activation and germination (12). Dormancy is a common strategy amongst fungi and bacteria to survive unfavourable external conditions. The morphology and physiology of dormant cells in nature are extremely diverse. To become germinable after dormancy many (fungal) spores require an "after-ripening period" (e.g. a cold period), and/or an activation treatment. This treatment may include thermal activation, chemical activation (detergents, organic acids, amino acids, etc.) or light activation $(6,12,22)$. Generally, germination of fungal spores is characterized by swelling of the spores and the formation of germ tubes, accompanied by increase of the respiration rate, DNA, RNA, and protein synthesis $(6,12)$. Furthermore, the nutritional requirements for germination vary considerably e.g. Aspergillus spores require only $\mathrm{CO}_{2}$, whereas Rhizopus spores need a carbon and nitrogen source $(7,12,18)$.

A typical means of controlling germination in fungi, bacteria and plants is self-inhibition. It has been previously observed that many fungi germinate poorly at high spore concentrations (crowding effect) and this suggested the presence of some inhibitory substance(s) produced by the organism $(10,17)$. Various self-inhibitors, such as nonanoic acid, 5isobutyroxy- $\beta$-ionone, vanillic acid and the cinnamic esters 3,4 dimethoxycinnamic acid methyl ester and methyl cis-ferulate have been identified after extraction from culture filtrates of fungi $(10,15,17)$. Self-inhibition has the obvious advantage of preventing rapid germination of all spores at the same time and place, which ensures survival in fluctuating 
environmental conditions and stimulates dissemination in nature $(17,22)$. To date the mechanism of action of self-inhibitors is not well understood. It is known that the cinnamic esters inhibit germination at the initiation of germ tube emergence, and it has been suggested that cinnamic esters may be pre-formed and remain bound to the cell surface (17). Nonanoic acid, on the contrary, is known to prevent swelling of the spores (15). Moreover, nonanoic acid appeared to be widely produced amongst fungi such as Aspergillus niger, Syncephalastrum racemosus, Geotrichum candidum, Penicillium expansum, Rhizopus stolonifer and Mucor plombeus $(10,15)$.

The criterion most frequently used to measure germination is emergence of the germ tubes and traditionally this has been determined microscopically. In this study we have applied flow cytometry to follow the germination process. In this system particles pass one by one in a fluid stream through a measuring apparatus, which simultaneously analyses scattered and fluorescence light from the particles. In combination with suitable fluorescent probes this offers the possibility to determine various cellular parameters such as size, enzymatic activity and intracellular $\mathrm{pH}$.

In this work the germination of $R$. oligosporus sporangiospores and the mechanism of action of nonanoic acid were investigated. Germination of $R$. oligosporus spores has previously been shown to be optimal at $37^{\circ} \mathrm{C}$ and at $\mathrm{pH} \mathrm{4}$, and was stimulated by glucose and $\mathbf{L}$-alanine $(7,18)$, but the physiological processes which take place during the germination process are not understood. We present evidence that $\mathrm{pH}_{\text {in }}$ increase is associated with swelling and germination of $R$. oligosporus sporangiospores, and that inhibition of germination by nonanoic acid is mediated by the capacity of this substance to dissipate the $\mathrm{pH}$ gradient.

\section{Materials and Methods}

Abbreviations. The following abbreviations are used in this report: cF, 5-(and-6)-carboxyfluorescein; cFDA, 5-(and-6)-carboxyfluorescein diacetate; CDM, Czapek and DOX synthetic medium for germination; cAMP, cyclic adenosine 3',5'-monophosphate.

Organisms and growth conditions. Rhizopus oligosporus NRRL 5905 was grown 5 to 7 days on malt extract agar slants at $30^{\circ} \mathrm{C}$. Sporangiospore suspensions were obtained by adding $9 \mathrm{ml}$ dilution medium ( $8.5 \mathrm{~g} / 1 \mathrm{NaCl}$ with $1 \mathrm{~g} / 1$ neutralized bacteriological peptone (Oxoid Ltd.)) to the agar slant and vortexing the tube thoroughly. The spore suspensions were subsequently filtered through a $30 \mu \mathrm{m}$ nylon filter to remove mycelium and other debris, and used immediately.

Fluorescence staining of spore suspensions. The $\boldsymbol{R}$. oligosporus spore suspensions were washed twice by centrifugation in an Eppendorf centrifuge in Czapek and DOX synthetic medium for germination (CDM, OXOID Ltd.), set to $\mathrm{pH} 4.0$ with lactic acid (final concentration less than 0.05 $\mathrm{mM})$. Subsequently, the suspension was incubated $20 \mathrm{~min}$ in the presence of cFDA $(0.22 \mathrm{mM})$ at $40^{\circ} \mathrm{C}$, washed twice with CDM and resuspended in malt extract broth adjusted to $\mathrm{pH} 4.0$ with lactic acid (unless indicated otherwise). 

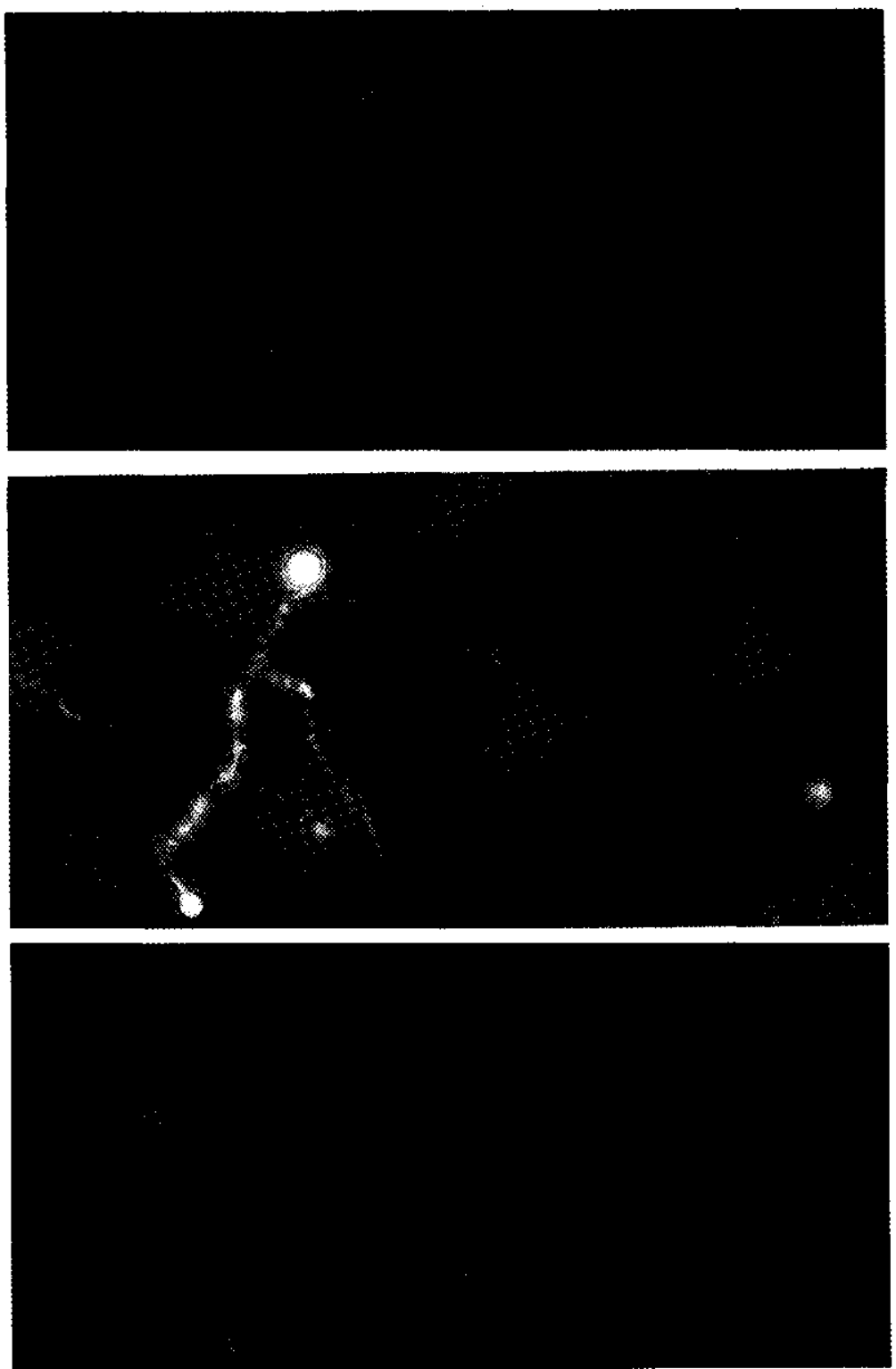

FIG. 1. Fiuorescent microscope analysis of $R$. oligosporus sporangiospores at the start of the incubation (A), after 5 hours incubation in mait extract broth (B), and after 5 hours incubation in Czapek and Dox medium $(\mathrm{C})$. The spores were previously stained with carboxyfluorescein and subsequently incubated at $37^{\circ} \mathrm{C}$ at $\mathrm{pH} 4$. Magnification $x 400$. 
Determination of germination. Germination of $R$. oligosporus spores was determined microscopically and by flow cytometry at one hour intervals. For microscopic analysis at least 140 spores were counted at random and germination was defined as the extension of a germ tube to one-half the diameter of the spore (18). The spore suspensions contained approx. $1 \times 10^{6}$ spores $/ \mathrm{ml}$. Samples for flow cytometric analysis were prepared by taking $100 \mu \mathrm{l}$ aliquots, which were diluted into $2 \mathrm{ml} C D M$ (adjusted to $\mathrm{pH} 4.0$ with lactic acid). The germination was evaluated in malt extract broth in the absence and in the presence of various concentrations of nonanoic acid (the $\mathrm{pH}$ was re-adjusted to $\mathrm{pH}$ 4 with sodium hydroxide).

Flow cytometric analysis. Analysis of individual spores was performed with a Partec PAS-IIIi flow cytometer (Partec GMBH, Münster, Germany), equipped with an air-cooled argon ion laser (excitation wavelength $488 \mathrm{~nm}$ ), which was operated at $15 \mathrm{~mW}$. The instrument was set up to collect 4 parameters: scattered light $(488 \mathrm{~nm})$ at low and wide angle, and fluorescent light at emission wavelengths of $515 \mathrm{~nm}$ and $560 \mathrm{~nm}$. Low angle light scatter (forward scatter) was used as an indicator of cell size and wide angle light scatter $\left(90^{\circ}\right.$ or side scatter) was used as an indicator of cell shape. The results are represented in 2 parameter dot plots in which the $\mathrm{X}$-axis and $\mathrm{Y}$-axis are arbitrarily divided into 64 channels, relative to the intensity of the incoming signal. A logarithmic amplification of the incoming signal was used to measure a wider range of signals (1.5 decade and 3 decade scale for scatter and fluorescence parameters, respectively). The sample analysis time was $2 \mathrm{~min}$. in which approx. 10000 particles were analyzed. The spores were separated from background by their side and forward scatter characteristics, and consequently the total number of spores (fluorescent and non-fluorescent) was determined. The fluorescence intensity of the particles was calculated as the square root of the multiplication of the 515 and $560 \mathrm{~nm}$ fluorescence signals (after recalculation from log mode to linear mode).

Determination of intracellular pH. The intracellular $\mathrm{pH}$ of individual fluorescent cells was determined by flow cytometry from the ratio of the $515 \mathrm{~nm}$ signal ( $\mathrm{pH}$ sensitive wavelength) with the $560 \mathrm{~nm}$ signal (less $\mathrm{pH}$ sensitive wavelength) from $\mathrm{cF}$ in the cells. The incoming log mode signals were recalculated to linear mode before determination of the ratio. For determination of the mean $515 / 560 \mathrm{~nm}$ ratio for all spores (fluorescent and non-fluorescent), it was assumed that the nonfluorescent (inactive) cells did not have a $\mathrm{pH}$ gradient. Calibration of the $\mathrm{pH}_{\text {in }}$ was performed by the best fit of the Henderson-Hasselbalch equation $\left(\mathrm{pK}_{\mathrm{a}}=6.25, \mathrm{R}_{\min }=0.755, \mathrm{R}_{\max }=1.50\right.$ ) after measuring the fluorescence ratio $(515 \mathrm{~nm} / 560 \mathrm{~nm})$ in spores resuspended in growth medium at various $\mathrm{pH}$ values containing $1 \%$ acetic acid to equilibrate $\mathrm{pH}_{\text {in }}$ and $\mathrm{pH}_{\text {out }}$.

\section{Results}

Germination of $\boldsymbol{R}$. oligosporus sporangiospores. The germination of $\boldsymbol{R}$. oligosporus sporangiospores in malt extract broth was determined microscopically and with flow cytometry. For flow cytometric analysis the spores were stained with $\mathrm{cF}$ by incubation with cFDA. The non-fluorescent cFDA is passively transported into intact cells and subsequently cleaved by esterases, which results in intracellular accumulation of fluorescent $\mathrm{cF}$ (5). Fluorescence of $\mathrm{cF}$ at $515 \mathrm{~nm}$ is highly $\mathrm{pH}$ dependent, which allows measurement of the 
$\mathrm{pH}_{\mathrm{in}}$ by measuring the ratio of the $515 \mathrm{~nm}$ signal with the much less $\mathrm{pH}$ dependent signal at $560 \mathrm{~nm}$. Subsequently, forward scatter (indicating particle size), fluorescence intensity and the $515 / 560 \mathrm{~nm}$ ratio of the spores were determined simultaneously with flow cytometry. $R$. oligosporus sporangiospores are smooth-walled, round to oval and 5 to $10 \mu \mathrm{m}$ in length (Fig. 1A). The spores were easily detected and enumerated in malt extract broth by flow cytometry (Fig. 2B), while initially only a small percentage (up to $35 \%$ ) of these spores were fluorescently stained (Fig. 2A). This suggested that in at least a part of the dormant spores intracellular esterases are active. The staining was not influenced by the absence or presence of glucose (data not shown).

\section{Time (hours)}

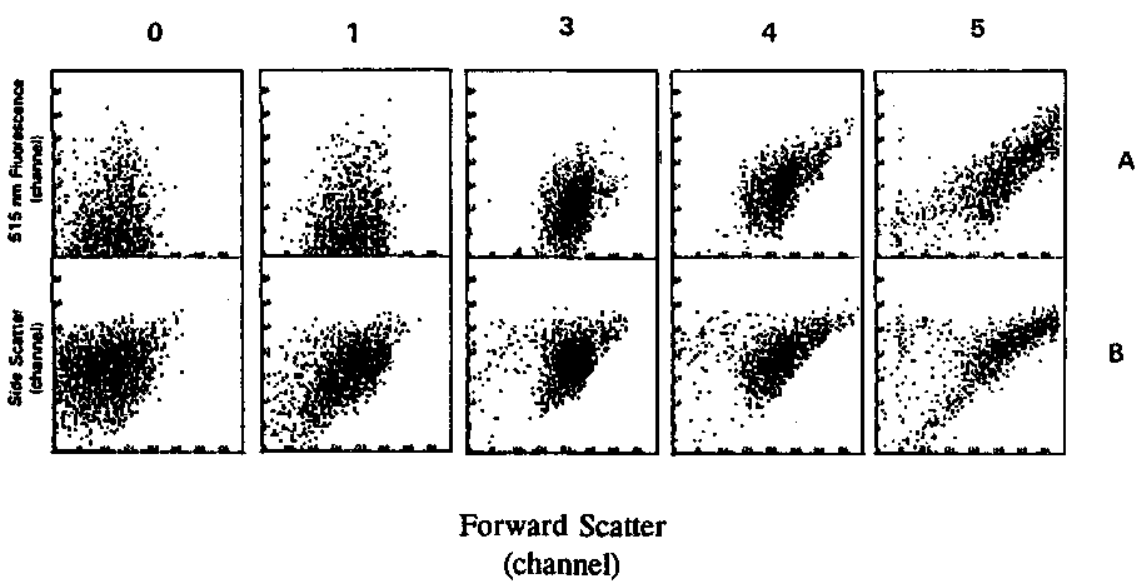

FIG. 2. Flow cytometric derived dot plots of forward scatter and fluorescence (series A), and dot plots of forward scatter and side scatter (series B), measured simultaneously during germination of $R$. oligosporus sporangiospores in malt extract broth $\mathrm{pH} 4.0$ at $37^{\circ} \mathrm{C}$. Particle size is indicated by the forward scatter ( $x$-axis), in both A and B. Fluorescent spores are represented in series A, and the total spore population in series B. The spores were previously stained with carboxyfluorescein and subsequently incubated for the time period indicated. Germinating spores with detectable germ tubes are in the top right part of the dot plots. The $x$ and $y$ axis are a 1.5 and 3 decade log scale, respectively, arbitrarily divided in 64 channels. The number of analyzed cells was approx. 10000.

In malt extract the spores rapidly increased in size (swelling) as determined from the increase of the forward scatter in the side scatter/forward scatter dot plots (Fig. 2B). The fluorescent spores are depicted in the $515 \mathrm{~nm}$ fluorescence/forward scatter dot plots (Fig. 2A). During incubation the spores showed a synchronous increase in forward scatter 
and fluorescence intensity, and the dot plots after 3 hours incubation show that almost all spores had become fluorescent, presumably because during the incubation the esterase activity increased and CFDA is hydrolysed to cF. All swollen (fluorescent) spores formed germ tubes approx. 2 hours later. In spores which formed a germ tube (illustrated in Fig. 1B), the fluorescence intensity and forward scatter were further increased (top right cells in dot plots measured after 5 hours incubation (Fig 2A and B)).

When the spores were incubated in CDM (Fig. 3) two distinct populations became increasingly evident in the side scatter/forward scatter dot plots; small spores (events with low forward scatter) and swollen spores (events with increased forward scatter). The swollen spores represented about $30 \%$ of all spores. As illustrated in the $515 \mathrm{~nm}$ fluorescence/forward scatter dot plots, which were measured simultaneously, only the spores with increased forward scatter were fluorescent. The flow cytometry results and microscopical analysis (Fig. 1C) showed that the swollen, fluorescent spores were smaller than in malt extract broth (Fig. 1B). After 8 hours approx. $10 \%$ of the spores formed germ tubes as determined by microscopical analysis.

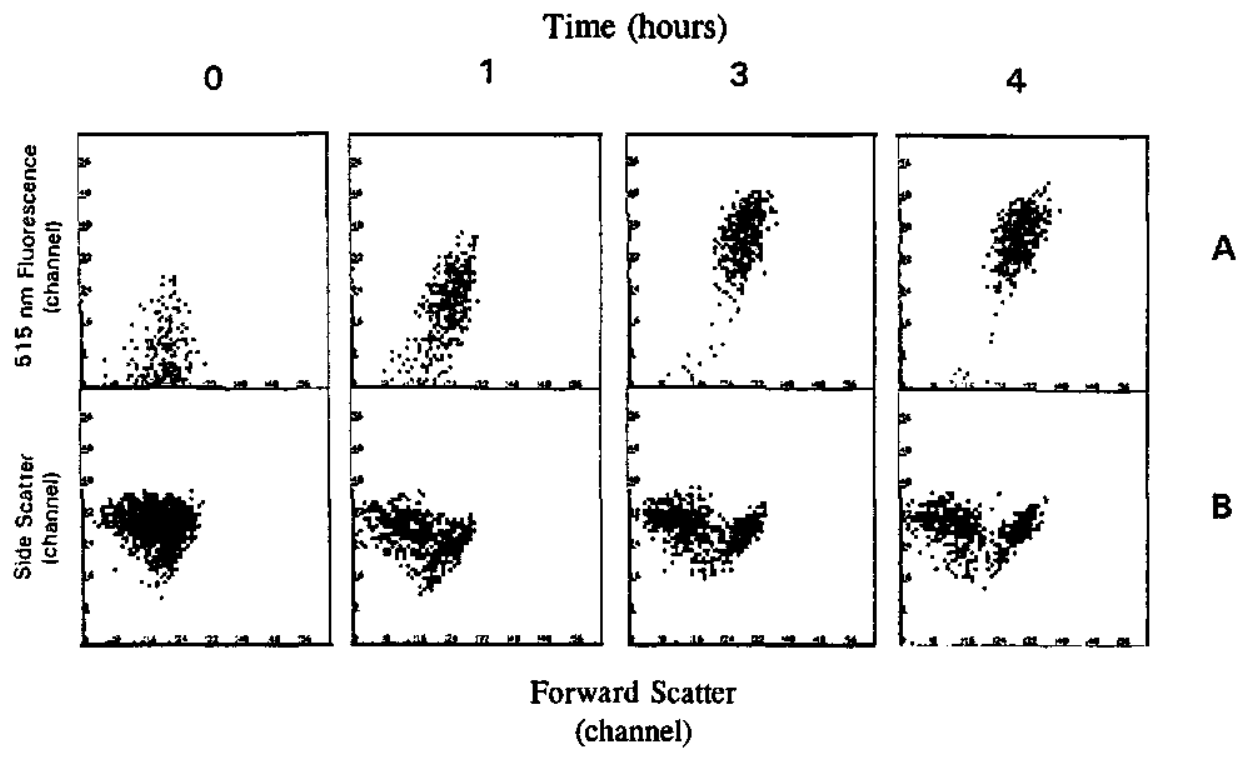

FIG. 3. Flow cytometric derived dot plots of forward scatter and fluorescence (series A), and dot plots of forward scatter and side scatter (series B), measured simultaneously during germination of $R$. oligosporus sporangiospores in Czapek and Dox medium pH 4.0 at $37^{\circ} \mathrm{C}$. Particle size is indicated by the forward scatter (X-axis), in both $A$ and $B$. Fluorescent spores are represented in series $A$, and the total spore population in series B. Staining protocol was the same as described in legend to Fig. 2 . 


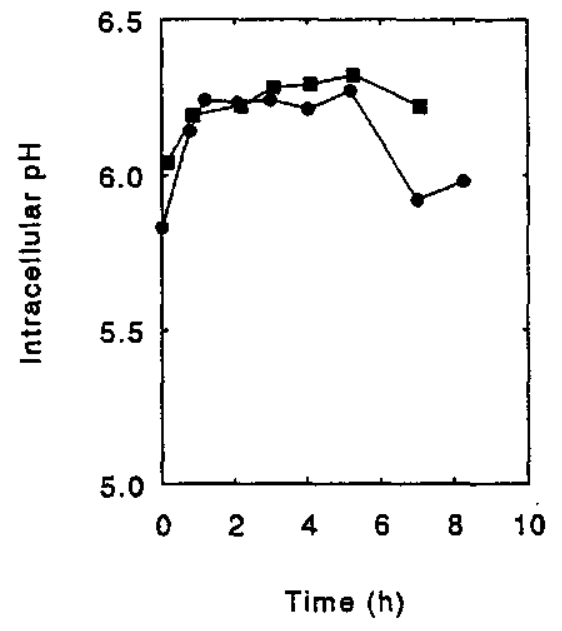

FIG. 4. The mean $\mathrm{pH}_{\text {in }}$ of fluorescent $R$. oligosporus sporangiospores in malt extract broth, $\mathrm{pH} 4$ $(\square)$, and Czapek and Dox synthetic medium, $\mathrm{pH} 4(\bullet)$. The incubation was performed at $37^{\circ} \mathrm{C}$. The $\mathrm{pH}_{\mathrm{in}}$ was determined by flow cytometry from the ratio of the $515 \mathrm{~nm}$ with the $560 \mathrm{~nm}$ fluorescence signal. The excitation wavelength was $488 \mathrm{~nm}$.

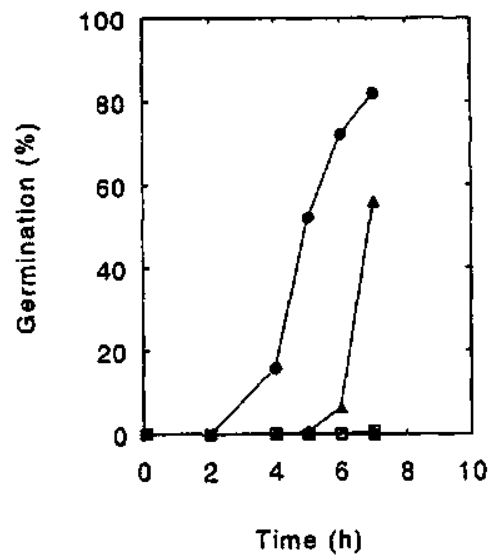

FIG. 5. Germination of $R$. oligosporus sporangiospores in the absence $(\theta)$ and presence of $0.25 \mathrm{mM}$ $(\Delta), 0.5 \mathrm{mM}(\square), 1 \mathrm{mM}(O)$ and $2 \mathrm{mM}(\Delta)$ nonanoic acid. The spores were incubated at $37^{\circ} \mathrm{C}$ in malt extract broth ( $\mathrm{pH} 4$ ). The spores were analyzed microscopically by counting at least 140 cells at random. Germination was defined as the extension of a germ tube to at least one-half the diameter of the spore. 
Simultaneously, the $\mathrm{pH}_{\text {in }}$ of the $R$. oligosporus sporangiospores was determined by the $515 / 560 \mathrm{~nm}$ ratio. At the start of the incubation the (mean) $\mathrm{pH}_{\text {in }}$ of the fluorescent spores in malt extract broth and CDM was approx. 5.9 and was increased to approx. 6.3 in 1.5 hours (Fig. 4).

Effect of nonanoic acid on germination of $R$. oligosporus sporangiospores. The germination of the $R$. oligosporus sporangiospores in malt extract broth was determined in the absence and presence of nonanoic acid. In the absence of nonanoic acid the spores started to form germ tubes after a lag time of about 3 hours, and after 5 hours more than $50 \%$ of the spores had formed germ tubes, as was determined microscopically (Fig. 5). In the presence of $0.25 \mathrm{mM}$ nonanoic acid the lag time was increased to approx. 6 hours. In the presence of $1 \mathrm{mM}$ nonanoic acid emergence of germ tubes was inhibited for at least 7 hours, but after 18 hours $47 \%$ of the spores germinated, whereas in the presence of $2 \mathrm{mM}$ nonanoic acid the germination after 18 hours was less than $1 \%$ (data not shown).

Simultaneously, the forward scatter (indicating size) of the spores was analyzed by flow cytometry (Fig. 6). In the absence of nonanoic acid (Fig. 6, serie a), the forward scatter of the spores was increased after 3 hours, which indicated swelling. After 5 hours a subpopulation of spores (representing approx $40 \%$ of all spores) could be distinguished with a significant increased forward scatter, most likely indicating emergence of germ tubes. After 7.5 hours the forward scatter of the spores suggested that most spores were germinated. This is in agreement with observations made using microscopy. In the presence of $0.25 \mathrm{mM}$ nonanoic acid (Fig. 6, serie b) swelling was slightly suppressed and emergence of germ tubes was delayed. In the presence of $0.5 \mathrm{mM}$ nonanoic acid (fig. 6 , serie c) swelling was significantly inhibited and emergence of germ tubes within 7.5 hours was prevented, whereas in the presence of $1 \mathrm{mM}$ and higher concentrations of nonanoic acid (Fig. 6, serie $d$ and e) swelling was completely inhibited. In the presence of $2 \mathrm{mM}$ nonanoic acid the spores had even slightly shrunk, as determined from the decreased forward scatter (Fig. 6, serie e).

In the same experiment the $\mathrm{pH}_{\text {in }}$ distribution of the spores in suspension was also determined at an extracellular $\mathrm{pH}$ of 4 (Fig. 7A). At the start of the incubation the $\mathrm{pH}_{\mathrm{in}}$ values of the fluorescent spores ranged from 5 to 6.5. The mean $\mathrm{pH}_{\mathrm{in}}$ was approx. 5.7. Within 1 hour the $\mathrm{pH}_{\mathrm{in}}$ shifted approx. $0.5 \mathrm{pH}$ unit to higher $\mathrm{pH}$ values. After 6 hours incubation the $\mathrm{pH}_{\text {in }}$ ranged approx. from 5.5 to 6.7 , and the mean $\mathrm{pH}_{\text {in }}$ was 6.3 , and the number of fluorescent spores was augmented from $40 \%$ to $90 \%$ of the total number of spores. In the presence of $1 \mathrm{mM}$ nonanoic acid the $\mathrm{pH}_{\text {in }}$ shifted to lower $\mathrm{pH}$ values (Fig. 7B), and the number of fluorescent spores decreased to $20 \%$ of the total number. The mean $\mathrm{pH}_{\text {in }}$ of the spores was calculated from the $\mathrm{pH}_{\text {in }}$ of the individual cells (Fig. 8). In the presence of increasing concentrations of nonanoic acid the $\mathrm{pH}_{\text {in }}$ decreased gradually, and in the presence of $2 \mathrm{mM}$ nonanoic acid the $\mathrm{pH}$ gradient was almost completely dissipated. 
Time (hours)

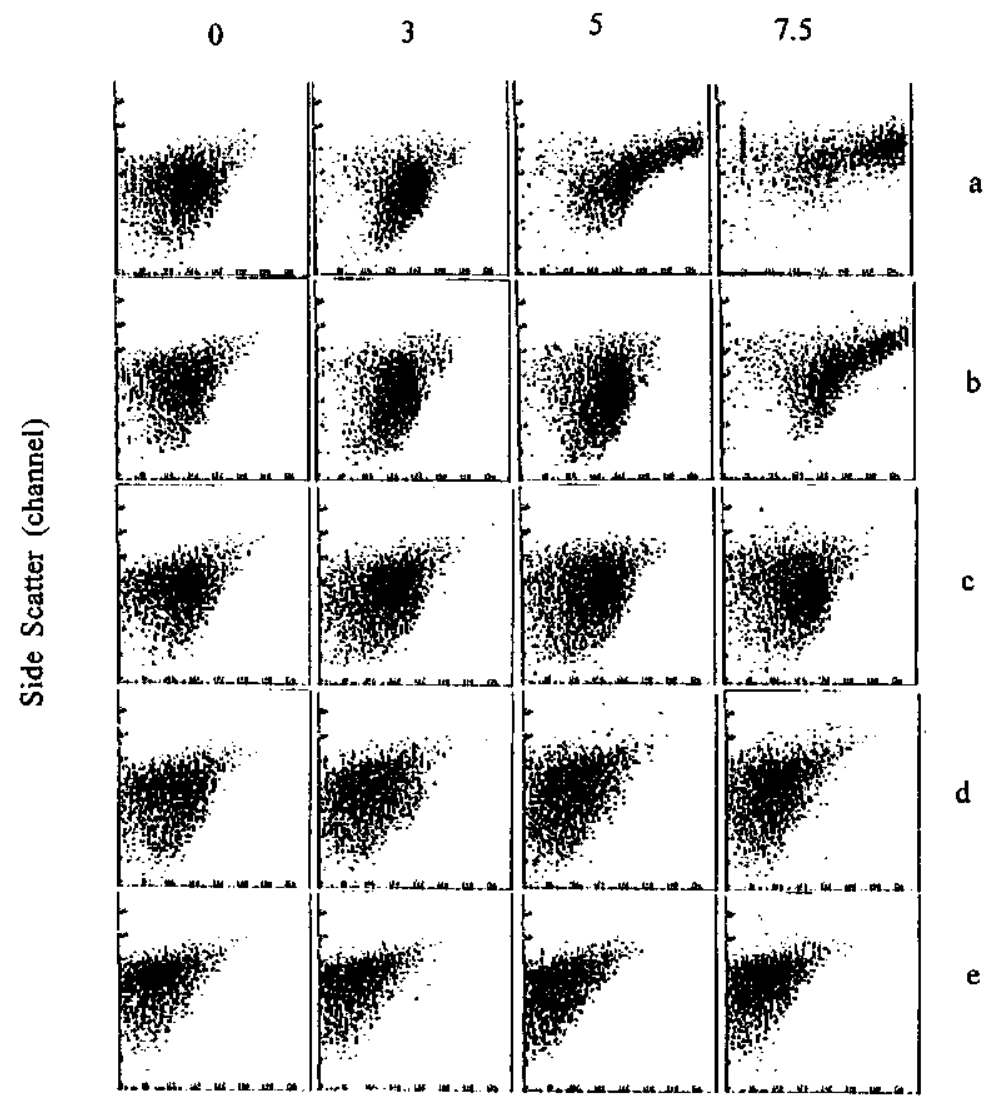

Forward Scatter (channel)

FIG. 6. Size of $R$. oligosporus sporangiospores determined with flow cytometry. The results are plotted as 2 parameter dot plots of forward scatter (indicating particle size) with side scatter. The spores were incubated in Malt extract broth $\left(\mathrm{pH} 4,37^{\circ} \mathrm{C}\right.$ ) in the absence (a), or presence of $0.25 \mathrm{mM}$ (b), $0.5 \mathrm{mM}$ (c), $1 \mathrm{mM}$ (d) or $2 \mathrm{mM}$ (e) nonanoic acid. The number of analyzed cells was approx. 10000 . Germinating spores with emerged germ tubes are depicted in the top right part of the 2 parameter dot plots. The X-and Y-axis are a 1.5 decade log scale divided arbitrarily in 64 channels. 


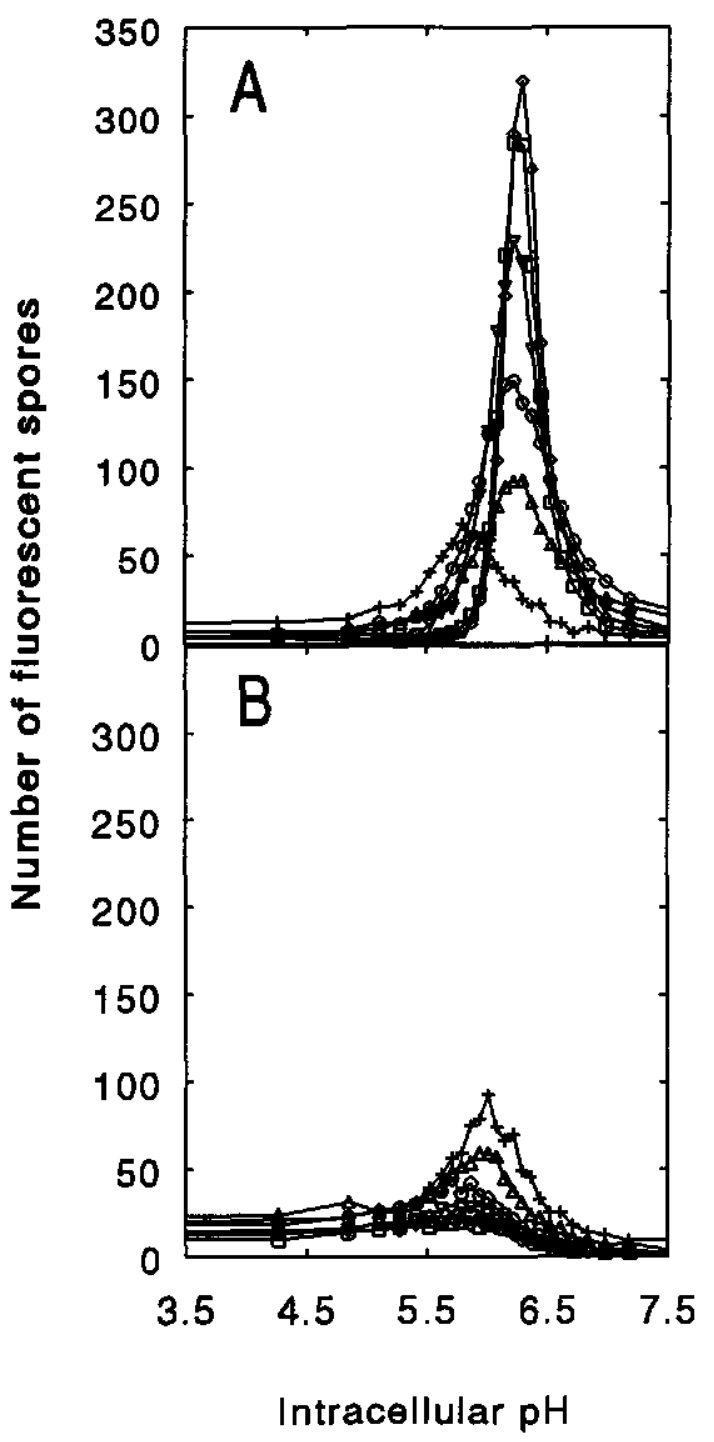

FIG. 7. The $\mathrm{pH}_{\mathrm{in}}$ distribution of fluorescent $R$. oligosporus sporangiospores in the absence (A) or presence $(B)$ of $1 \mathrm{mM}$ nonanoic acid after $0.15(+), 0.75(\Delta), 3(0), 4(\nabla), 6(\diamond)$ and $7.5(\square)$ hours incubation in malt extract broth adjusted to $\mathrm{pH} 4$ with lactic acid at $37^{\circ} \mathrm{C}$. For comparison, the total number of spores (fluorescent and non-fluorescent) is standardised to 2000 . The $\mathbf{p H}$ in was determined by flow cytometry from the ratio of the $515 \mathrm{~nm}$ with the $560 \mathrm{~nm}$ fluorescence signal. The excitation wavelength was $488 \mathrm{~nm}$. 


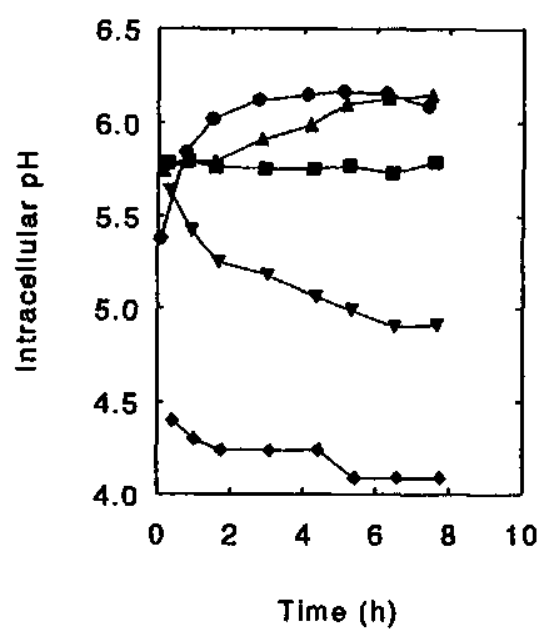

Fig. 8. The mean $\mathrm{pH}_{\mathrm{in}}$ of $R$. oligosporus sporangiospores in malt extract broth (pH 4) in the absence (๑) and presence of $0.25 \mathrm{mM}(4), 0.5 \mathrm{mM}(\square), 1 \mathrm{mM}(v)$ and $2 \mathrm{mM}(\bullet)$ nonanoic acid. The incubation was performed at $37^{\circ} \mathrm{C}$. The $\mathrm{pH}_{\text {in }}$ was determined by flow cytometry from the ratio of the $515 \mathrm{~nm}$ with the $560 \mathrm{~nm}$ fluorescence signal. The excitation wavelength was $488 \mathrm{~nm}$.

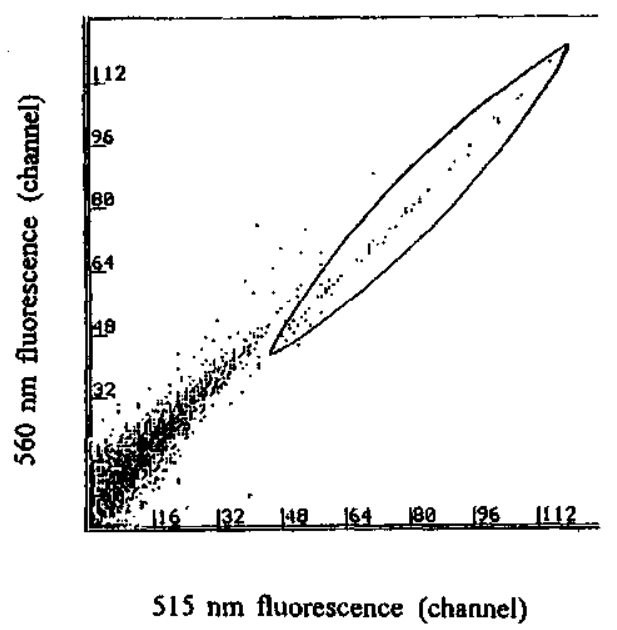

FIG. 9. Two parameter dot plot of the 515 fluorescence and the $560 \mathrm{~nm}$ fluorescence signals of $R$. oligosporus sporangiospores after 5.5 hours in the presence of $2 \mathrm{mM}$ nonanoic acid measured with flow cytometry. The total number of spores was 47134 , of which 2784 spores were fluorescent. The spores with an increased ratio and fluorescence intensity (60 events) are in the encircled area. The Xand $\mathrm{Y}$-axis are a 3 decade $\log$ scale divided arbitrarily in 128 channels. 
After 6 hours incubation in the presence of $2 \mathrm{mM}$ nonanoic acid a small population of spores (60 out of 47000 spores $(0.13 \%)$ ) with increased ratio and fluorescence intensity was detected (Fig. 9). In contrast, after 32 hours incubation no germinated spores could be detected microscopically. This result particularly illustrates the high potential of the flow cytometric method to rapidly identify small subpopulations in a cell population.

These combined morphological and physiological results suggests that swelling is associated with an increase of the $\mathrm{pH}_{\mathrm{in}}$. When this $\mathrm{pH}_{\text {in }}$ increase was prevented by addition of nonanoic acid, swelling and subsequent emergence of germ tubes did not occur.

\section{Discussion}

In this study, germination of $R$. oligosporus sporangiospores was evaluated with flow cytometry. A major advantage of flow cytometry is the possibility to analyze simultaneously morphological and physiological parameters of a large number of cells. The low angle light scatter (forward scatter) of the spores proved to be a very accurate indicator of size. Given that fluorescent spores hydrolyse $\mathrm{cFDA}$ and retain $\mathrm{cF}$, the fluorescence intensity of the spores (due to accumulation of $\mathrm{cF}$ ) could be used as indication of metabolic (enzymatic) activity. Furthermore, the $\mathrm{pH}_{\text {in }}$ could be determined effectively from the ratio of the $515 \mathrm{~nm}$ emission with the $560 \mathrm{~nm}$ emission. The use of the fluorescence ratio technique in combination with flow cytometry to measure the $\mathrm{pH}_{\text {in }}$ has the main advantage that background problems due to leakage of fluorescent probe from the spores are avoided and that cells can be analyzed individually. The $\mathrm{pH}_{\mathrm{in}}$ in spores was calibrated by equilibration of the intracellular $\mathrm{pH}$ with the extracellular $\mathrm{pH}$. This was achieved by using acetic acid (1\%), since the commonly used ionophores nigericin and valinomycin and the polyene antibiotic nystatin were not effective $(8,16,20)$. Given that the $\mathrm{pK}_{\mathrm{a}}$ of carboxyfluorescein is 6.3 (11) it is difficult to measure accurately $\mathrm{pH}$ values lower than approx. 5. However, because of the high sensitivity of the flow cytometer the ratios could be determined accurately and these in turn allowed an estimation of the corresponding $\mathrm{pH}_{\mathrm{in}}$ values.

A schematic representation of the germination process of $R$. oligosporus sporangiospores is shown in Fig. 10. Germination is characterized by swelling (stage I) and subsequent emergence of germ tubes (stage II). Initially, the spores contain insufficient available endogenous carbon and/or energy sources and an exogenously added carbon or energy source is needed for swelling (18). Furthermore, synthesis of fatty acids is required, as was demonstrated for Rhizopus stolonifer (19). This is most likely because in Rhizopus sp. a new inner wall layer, the germination wall $(6)$, is formed during swelling $(13,28)$. During swelling the oxygen consumption and RNA synthesis are significantly increased $(6,12)$. We have shown that swelling of $R$. oligosporus spores is associated with an increase in fluorescence and $\mathrm{pH}_{\mathrm{in}}$. In the second stage germ tubes are formed. The germ tube wall 


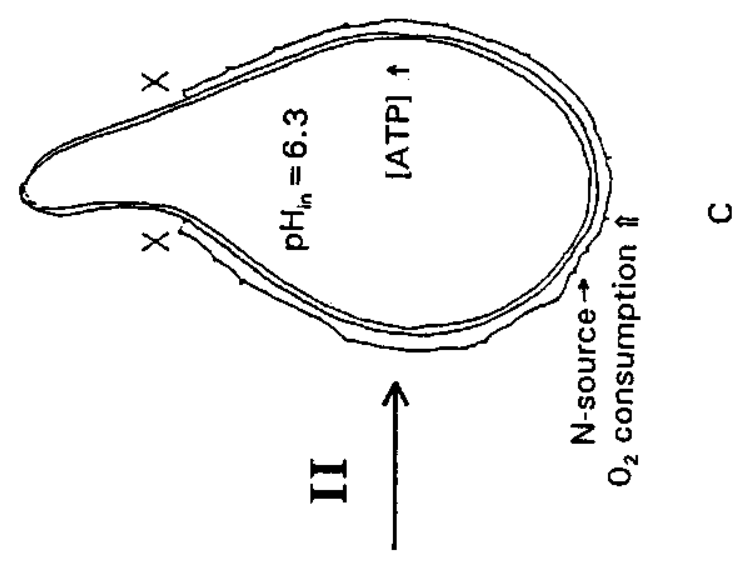

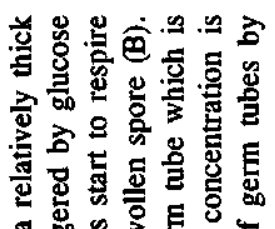

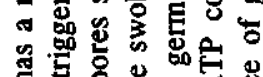

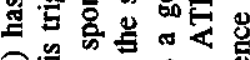

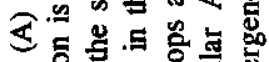

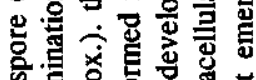

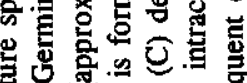

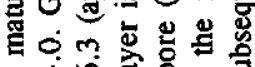

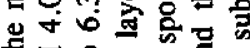

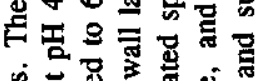

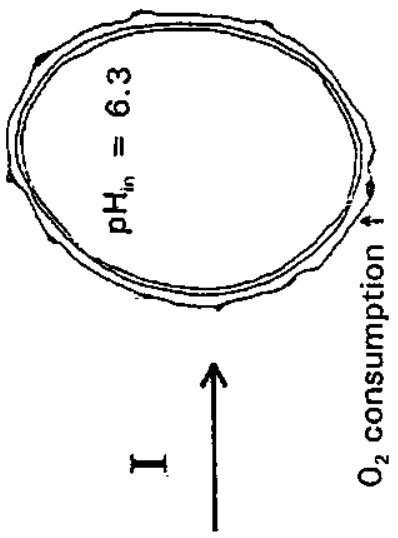

的总

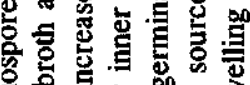

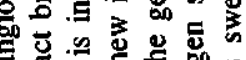

$\infty$

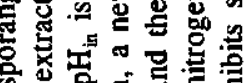

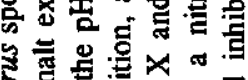

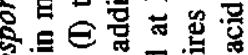

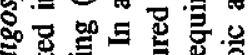

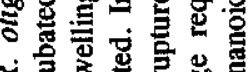

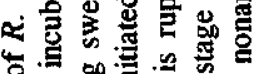

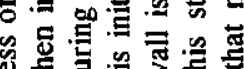

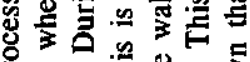

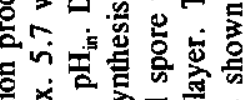

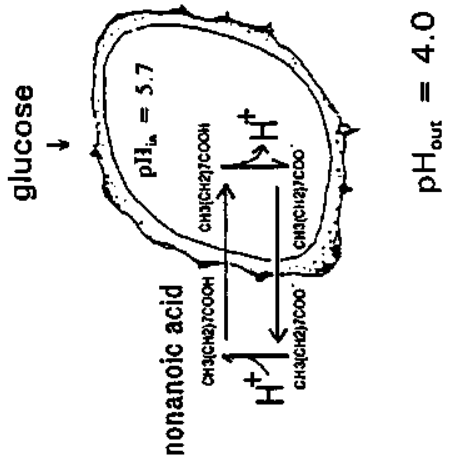

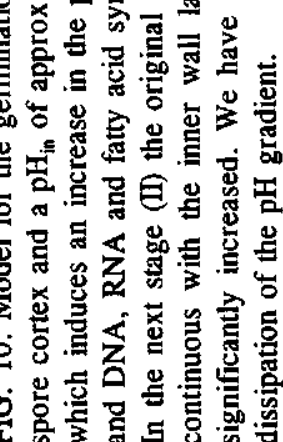


layer is continuous with the inner wall layer of the swollen spore, emerging through the original outer spore wall. $R$. oligosporus spores require a nitrogen source for emergence of the germ tubes (18). During germ tube elongation the intracellular ATP levels are increased significantly (unpublished data). In germinated spores formation of compartments was observed (most likely by emergence of vacuoles). Although the $\mathrm{pH}_{\text {in }}$ in these spores did not appear to be influenced significantly by this phenomenon, a potential contribution of vacuolar $\mathrm{pH}$ to the observed $\mathrm{pH}_{\text {in }}$ must be considered, i.e. the cytoplasmic $\mathrm{pH}$ may be slightly underestimated.

Up to now the mechanism by which germination of $R$. oligosporus sporangiospores is triggered and the role of the $\mathrm{pH}_{\mathrm{in}}$ in germination are unclear. In $R$. oligosporus swelling of the spores and subsequent emergence of germ tubes is triggered by glucose (18), a phenomenon which has also been described in Mucor racemosus and Pilobolus longipes sporangiospores $(2,25)$. How glucose triggers germination in $R$. oligosponus is not understood. Glucose is known to induce a (transient) increase in cAMP $(2,4,24)$, and a rise in cAMP has been reported to be responsible for 'breaking of dormancy' in spores from Phycomyces blakesleeanus and Saccharomyces cerevisiae ascospores $(3,23,26)$. It has also been reported that in $S$. cerevisiae and Fusarium oxysporum uptake of glucose stimulates the plasma membrane-located $\mathrm{H}^{+}$-ATPase $(4,9)$, resulting in extrusion of $\mathrm{H}^{+}$. In $S$. cerevisiae the glucose-induced $\mathrm{H}^{+}$-ATPase activation was independent of the glucose-induced cAMP increase (21). Whether the initiation of germination in $R$. oligosporus sporangiospores is regulated by cAMP or activation of the $\mathrm{H}^{+}$-ATPase remains to be elucidated. We suggest that increase of the $\mathrm{pH}_{\text {in }}$ is crucial for germination and most likely stimulates various processes such as protein synthesis, enzyme activation and cell wall synthesis. The critical role of the $\mathrm{pH}_{\mathrm{in}}$ is supported by the inhibiting effect of nonanoic acid on the swelling and emergence of germ tubes. Our evidence suggests that the mechanism of action of nonanoic acid ( $\mathrm{pK}_{\mathrm{a}} 4.96$, i.e. $89 \%$ undissociated acid at $\mathrm{pH}$ 4) is by dissipation of the $\mathrm{pH}$ gradient, thereby preventing the increase of the $\mathrm{pH}_{\mathrm{in}}$ necessary for spore germination (Fig. 10). Other weak acids such as acetic acid, citric acid and palmitic acid inhibited germination less effectively than nonanoic acid. For instance, under the same conditions acetic acid $\left(\mathrm{pK}_{\mathrm{a}}\right.$ 4.76 , i.e. $83 \%$ undissociated acid at $\mathrm{pH} 4$ ) had a similar effect on the $\mathrm{pH}_{\mathrm{in}}$ of $R$. oligosporus spores, but at much higher concentrations ( $>30 \mathrm{mM}$ ) (data not shown).

Self-inhibitors such as the cinnamic esters cis-3,4- dimethoxycinnamic acid methyl ester and cis-ferulic acid methyl ester, did not inhibit swelling but prevented initiation of the germ tube elongation of urediniospores from rust fungi such as Uromyces phaseoli and Puccinia graminis (17). To date, the exact mode of action of these self-inhibitors has not been elucidated. The cinnamic esters were already effective at nanomolar concentrations and it was suggested that enzymes associated with the newly formed germ tube and which are necessary for germ tube extension, were reversibly inhibited (14). Furthermore, several extracted phenolic compounds such as vanillic acid and p-hydroxybenzoic acid were 
reported to be inhibit urediniospores of $P$. graminis at millimolar concentrations (27), but detailed information is lacking about their mechanism of inhibition.

Long chain fatty acids such as lauric, oleic and linoleic acid, have been described to inhibit germination of Bacillus cereus spores (1). Although it was suggested that in Bacillus these long chain fatty acids act by inhibition of binding of $\mathbf{L}$-alanine to the germination site, no data are available to support this hypothesis and it remains to be elucidated whether these compounds inhibit germination also by dissipation of the $\mathrm{pH}$ gradient in these bacterial spores, like nonanoic acid in $R$. oligosporus spores.

In conclusion, the viability of individual $R$. oligosporus sporangiospores could be efficiently assessed with flow cytometry. Increase of $\mathrm{pH}_{\mathrm{in}}$ proved to be critical for swelling and subsequent emergence of the germ tubes. This was demonstrated by the effect of nonanoic acid and other weak acids, which inhibited germination of $R$. oligosporus by dissipation of the $\mathrm{pH}$ gradient.

\section{Acknowledgements}

We thank Aidan Coffey and Rob Nout for critical reading of the manuscript.

\section{References}

1. Ababouch, L.H., F. Bouquartacha and F.F. Busta. 1994. Inhibition of I-alanine triggered Bacillus cereus T spore germination and outgrowth by fatty acids and glyceryl monododecanoate. Food Microbiol. 11:385-396.

2. Bourret, J.A. 1986. Evidence that a glucose-mediated rise in cyclic AMP triggers germination of Pilobolus longipes spores. Exp. Mycol. 10:60-66.

3. Bourret, J.A., L.L. Flora and L.M. Ferrer. 1989. Trehalose mobilization during early germination of Pilobolus longipes sporangiospores. Exp. Mycol. 13:140-148.

4. Brandāo, R.L., I.M. Castro, J.B. Passos, J.R. Nicoli and J.M. Thevelein. 1992. Glucose-induced activation of the plasma membrane $\mathrm{H}^{+}$-ATPase in Fusarium oxysporum. J. Gen. Microbiol. 138:1579-1586.

5. Breeuwer, P., J.L. Drocourt, N. Bunschoten, M.H. Zwietering, F.M. Rombouts and T. Abee. 1995. Characterization of uptake and hydrolysis of fluorescein diacetate and carboxyfluorescein diacetate by intracellular esterases in Saccharomyces cerevisiae, which result in accumulation of fluorescent product. Appl. Environ. Microbiol. 61:1614-1619.

6. Cooke, R.C. and J.M. Whipps. 1993. Ecophysiology of Fungi, p. 178-197. Blackwell Scientific Publications. Cambridge, UK.

7. De Reu, J.C. F.M. Rombouts and M.J.R. Nout. 1995. Influence of acidity and initial substrate temperature on germination of Rhizopus oligosporus sporangiospores during tempe manufacture. J. Appl. Bacteriol. 78:200-208.

8. De Reu, J.C. and P. Breeuwer. Unpublished data.

9. Eraso, P. and F. Portillo. 1994. Molecular Mechanism of regulation of yeast plasma membrane $\mathrm{H}^{+}-\mathrm{ATPase}^{-}$ by glucose. J. Biol. Chem. 269:10393-10399.

10. Garrett, M.K., and P.M. Robinson. 1969. A stable inhibitor of spore germination produced by fungi. Arch. 
Microbiol. 67:370-377.

11. Graber, M.L., D.C. DiLillo, B.L. Friedman and E. Pastoriza-Munoz. 1986. Characteristics of fluoroprobes for measuring intracellular $\mathrm{pH}$. Analytic. Biochem. 156:202-212.

12. Griffin, D.H. 1994. Spore dormancy and germination, p. 375-398. In D.H. Griffin, Fungal Physiology. John Wiley \& sons, Inc. New York.

13. Hawker, L.E. 1966. Germination: morphological and anatomical changes, p. 151-161. In Madelin, M.F.(ed.), The fungus spore. Butterworth \& Co. LTD., London, UK.

14. Hess, S.L., P.J. Allen, D. Nelson and H.H. Lester. 1975. Mode of action of methyl cis-ferulate, the selfinhibitor of stem nust uredospore germination. Physiol. Plant Pathol. 5:107-112.

15. Hobot, J.A., and K. Gull. 1980. The identification of a self-inhibitor from Syncephalastrum racemosus and its effect upon sporangiospore germination. Ant. Leeuwenhoek 46:435-441.

16. Kovác, L., E. Böhmerová and P. Butko. 1982. Ionophores and intact cells. I. Valinomycin and nigericin act preferentially on mitochondria and not on the plasma membrane of Saccharomyces cerevisiae. Biochim. Biophys. Acta 721:341-348.

17. Macko, V. R.C. Staples, Z. Yaniv and R.R. Granados. 1976. Self-inhibitors of fungal spore germination p. 73-98. In D.J. Weber and W.M. Hess (ed.), The fungal spore: form and function. John Wiley and Sons, London.

18. Medwid, R.D., and D.W. Grant. 1984. Germination of Rhizopus oligosporus sporangiospores. Appl. Environ. Microbiol. 48:1067-1071.

19. Nickerson, K.W., and E. Leastman. 1978. Cenulenin inhibition of spore germination in Rhizopus stolonifer. Exp. Mycol. 2:26-31.

20. Palacios, J., and R. Serrano. 1978. Proton permeability induced by polyene antibiotics. FEBS letters 91:198-201.

21. Passos, J.B., M. Vanhalewyn, R.L. Brandăo, I.M. Castro, J.R. Nicoli and J.M. Thevelein. 1992. Glucose-induced activation of plasma membrane $\mathrm{H}^{+}$-ATPase in mutants of the yeast Saccharomyces cerevisiae affected in cAMP metabolism, cAMP-dependent protein phosphorylation and the initiation of glycolysis. Biochim. Biophys. Acta 1136:57-67.

22. Sussmann, A.S., and H.O. Halvorson. 1966. Spores, their dormancy and germination. p. 150-192 and p. 270-315. Harper \& Row publishers, New York.

23. Thevelein, J.M. 1984. Cyclic-AMP content and trehalose activation in vegetative cells and ascospores of yeast. Arch. Micribiol. 138:64-67.

24. Thevelein, J.M. 1994. Signal transduction in yeast. Yeast 10:1753-1790.

25. Tripp, M.L., and J.L. Paznokas. 1982. Glucose-initiated germination of Mucor racemosus sporangiospores. J. Gen. Microbiol. 128:477-483.

26. Van Mulders, R.M., and A.J. van Laere. 1984. Cyclic AMP, trehalase and germination of Phycomyces blakesleeanus spores. J. Gen. Micribiol. 130:541-547.

27. Van Sumere, C.F., C. van Sumere-de Preter, L.C. Vining and G.A. Ledingham. 1957. Coumarins and phenolic acids in the Uredospores of wheat stem rust. Can. J. Microbiol. 3:847-862.

28. Weber D.J., and W.M. Hess. 1975. Diverse spores of fungi, p. 97-111. In P. Gerhardt, R.N. Costilow and H.L. Sadoff (ed.), Spores VI. American Society for Microbiology, Washington D.C. 
Chapter 5 


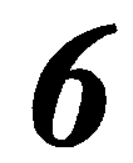

Role of the Cell Envelope in Resistance of Gram-Positive Bacteria to Detergents

Pieter Breeuwer, Aidan Coffey, Frank M. Rombouts, and Tjakko Abee

This chapter is submitted for publication to Applied and Environmental Microbiology 


\begin{abstract}
Growth of Lactococcus lactis and Bacillus subtilis was inhibited by the detergents Triton $\mathrm{X}-100$ and $N$-dodecyl- $N, N$-dimethyl-3-ammoniopropane sulfonate (Lauryl sulfobetaine) at concentrations below their critical micelle concentrations. $B$. subtilis cells were permeabilized and subsequently lysed in the presence of these detergents. Exponential phase L. lactis cells, however, were not permeabilized by Triton X-100 as demonstrated by (a) acid production of cells in the presence of a fermentable sugar, (b) maintenance of intracellular ATP levels, (c) negligible lactate dehydrogenase (LDH) activity in the extracellular medium, (d) inability of TOTO-1 to pass the cell envelope and bind to DNA, and (e) maintenance of a $\mathrm{pH}$ gradient. In contrast, $L$. lactis cells were permeabilized in the presence of Lauryl sulfobetaine as indicated by inhibition of sugar metabolism and dissipation of the $\mathrm{pH}$ gradient. The resistance of $L$. lactis to Triton $\mathrm{X}-100$ is most likely due to the protective function of the cell wall, since protoplasts were very sensitive Triton X-100 and were readily permeabilized. There are several indications, however, that intact $L$. lactis cells require energy for their resistance to Triton $X-100$. Addition of lactose $(10 \mathrm{mM})$ was necessary to restore the $\mathrm{pH}$ gradient, and minimalized leakage of $\mathrm{LDH}$ to the extracellular medium. Significantly, after incubation of $L$. lactis cells in the presence of Triton X-100, several proteins were released in the extracellular medium as evidenced by SDS-PAGE. The inhibition of growth of $L$. lactis by low concentrations of Triton X-100 is most likely caused by an inhibition and/or removal of cell-wall associated proteins which may be essential for growth.
\end{abstract}

\title{
Introduction
}

Detergents have a wide range of important applications both in biological research and in industrial processes. Some detergents, such as the cationic quaternary ammonium compounds have a strong bactericidal capacity. Others, such as anionic, zwitterionic and non-ionic detergents are considered to have weaker antimicrobial activity, but do have a variety of useful applications. The non-ionic detergent Triton X-100 is widely used for permeabilization of microbial cells $(16,25)$, and the anionic detergent sodium dodecyl sulphate (SDS) is noted for its protein denaturing ability. Zwitterionic detergents, like Chapso and Lauryl sulfobetaine have strong lipid solubilization capacities but, in contrast to SDS, a low protein denaturing ability (26).

The effects of detergents on lipid bilayers and liposomes have been studied in detail and a sequence of events has been proposed for the interaction of detergent with liposomes prepared from pure phospholipids (8). First, detergent molecules bind to the lipid bilayer. Subsequently, the bilayer is saturated with detergent molecules, resulting in bilayer 
destabilization and formation of mixed micelles. The size of the micelles will decrease upon increasing the detergent/phospholipid ratio. The interaction of detergents with bacterial cells, however, is possibly far more complex and it is not known whether the same principles may be directly applied.

In this study the effects of Triton X-100 and Lauryl sulfobetaine on the gram-positive bacteria Lactococcus lactis and Bacillus subtilis were investigated. Triton X-100 (Fig. 1A) has a polyethyleneglycol headgroup (with on average 9 to 10 ethylene oxide units) and a octylphenol hydrophobic tail. The critical micelle concentration (CMC) is $0.24 \mathrm{mM}(0.015$ $\%$ ) and the hydrophile-lipophile balance (HLB) is 13.5. The HLB value is indicative for the membrane solubilizing power of non-ionic detergents, i.e. detergents which have HLB values between 12.5 and 14.5 are considered most effective for solubilization of membranes (8). The aggregation number (i.e. the mean number of detergent molecules in a micelle) of Triton X-100 is 140 with a corresponding micellar weight of $90 \mathrm{kDa}$. Lauryl sulfobetaine (Fig. 1B) has an alkyl tail (of 12 units) and a sulfobetaine headgroup. The CMC of Lauryl sulfobetaine is $3.6 \mathrm{mM}(0.12 \%)$. The aggregation number is 55 with a micellar weight of $18 \mathrm{kDa}$.<smiles>CCC(CC)Oc1ccc(C(C)(C)CC(C)(C)C)cc1</smiles><smiles>CCCCCCCCCCC[N+](C)(C)CCCS(=O)(=O)[O-]</smiles>

FIG. 1. Structural formulas of (A) polyoxyethyleneglycol (9-10) p-t-octylphenol (Triton X-100), and (B) $N$-dodecyl- $N, N$-dimethyl-3-ammoniopropane sulfonate (Lauryl sulfobetaine). 
We demonstrate that growth of $B$. subtilis and $L$. lactis is inhibited by both detergents. The obvious explanation for this inhibition would be permeabilization of the cytoplasmic membrane. However, in contrast to Bacillus subtilis, L. lactis cells were apparently not permeabilized by Triton X-100. Therefore, the responses of $L$. lactis to Triton X-100 exposure are explored in more detail.

\section{Materials and Methods}

Abbreviations. The following abbreviations are used in this report: $\mathrm{cF}, 5$-(and-6)-carboxyfluorescein; cFDA, 5-(and-6)-carboxyfluorescein diacetate; cFDASE, 5-(and-6)-carboxyfluorescein diacetate succinimidyl ester; cFSE, 5-(and-6)-carboxyfluorescein succinimidyl ester; CMC, critical micelle concentration; HEPES, $N$-[2-Hydroxyethyl]piperazine- $N^{*}$-[2-ethanesulfonic acid]; $50 \mathrm{mM} \mathrm{KP_{i }} \mathbf{p H ~} 7$, $50 \mathrm{mM}$ potassium phosphate buffer $\mathrm{pH} 7.0$; LDH, lactate dehydrogenase; SDS-PAGE, sodium dodecylsulphate polyacrylamide gel electrophoresis; TOTO-1, 1,1'-(4,4,7,7-tetramethyl-4,7diazaundecamethylene)-bis-4-[3-methyl-2,3-dihydro-(benzo-1,3-thiazole)-2-methylidene]-quinolinium tetraiodide); Triton X-100, polyoxyethyleneglycol (9-10) p-t-octylphenol; Lauryl sulfobetaine, $N$-dodecyl- $N, N$-dimethyl-3-ammoniopropane sulfonate; $\mathrm{t}_{1 / 2}$, time needed for $50 \%$ efflux of original probe content.

Bacteria and growth conditions. Lactococcus lactis subsp. lactis (ATCC 19435 [the type strain]) was grown overnight at $30^{\circ} \mathrm{C}$ in $\mathrm{M} 17$ broth (Oxoid) with lactose $(0.5 \%$ (w/v)). Bacillus subtilis (ATCC 6051 [the type strain]) was grown overnight in brain heart infusion (BHI) broth (Oxoid) in a shaking water bath at $37^{\circ} \mathrm{C}$. The overnight cultures were diluted 5 -fold in fresh medium and incubated for 3 hours before harvesting at an optical density at $620 \mathrm{~nm}\left(\mathrm{OD}_{620}\right)$ of approximately 0.7 .

Growth of Lactococcus lactis and Bacillus subtilis in the presence of various detergents. L. lactis and B. subtilis cells were washed and resuspended in fresh M17 (with $0.5 \%$ lactose) and BHI, respectively. A concentration series of detergent in medium (up to $2 \%$ Triton X-100 or Lauryl sulfobetaine) was previously prepared in a microtiter plate and was diluted with an equal volume of cell suspension. The $\mathrm{OD}_{620}$ was approximately 0.05 at the start of the incubation. The cell suspensions were incubated at $30^{\circ}$ and $37^{\circ} \mathrm{C}$ for $L$. lactis and $B$. subtilis, respectively, and the $\mathrm{OD}_{620}$ was measured at 30 minute intervals with an EAR-400 plate reader (SLT labinstruments, Grödig, Austria).

L. lactis cells were washed and resuspended to an $\mathrm{OD}_{620}$ of approx 0.3 in a $50 \mathrm{mM}$ potassium phosphate buffer $\left(\mathrm{KP}_{\mathrm{i}}\right) \mathrm{pH} 7.0$ and pre-incubated for 1 hour both in the absence of detergent, and in the presence of $0.01 \%$ Triton X-100, $0.1 \%$ Triton X-100, and $0.1 \%$ Lauryl sulfobetaine. After incubation the number of cells was determined by plate count (M17 agar with $5 \mathrm{~g} / 1$ lactose) using $0.85 \% \mathrm{NaCl}, 0.1 \%$ neutralized bacteriological peptone as a dilution buffer. Additionally, a $1 \mathrm{ml}$ sample was withdrawn for analysis of solubilized and cellular proteins with SDS-PAGE. The remaining sample was washed twice and resuspended in the same volume of M17 broth, and growth of the cells was followed for 5 hours at $30^{\circ} \mathrm{C}$ by measuring the $\mathrm{OD}_{620}$.

SDS-PAGE. SDS-PAGE was performed as described by Laemmli (12) with gels containing $12.5 \%$ acrylamide. The protein samples were diluted $1: 1$ in sample buffer $(125 \mathrm{mM}$ Tris- $\mathrm{HCl} \mathrm{pH} 6.8,2.5 \%$ 
SDS, $25 \%$ glycerol, $0.25 \%$ bromophenolblue and $2.5 \%$ B-mercaptoethanol), boiled for $5 \mathrm{~min}$ at $100^{\circ} \mathrm{C}$ and applied to the gels. After electrophoresis the gels were silver stained according to the procedure of Morrissey (18). The molecular masses of the protein bands were estimated by using the following reference proteins: $\alpha$-lactalbumin $(14.4 \mathrm{kDa})$, Soybean Trypsin inhibitor $(20.1 \mathrm{kDa})$, Carbonic anhydrase $(30.0 \mathrm{kDa})$, Ovalbumin $(43.0 \mathrm{kDa})$, Bovine Serum Albumin $(67.0 \mathrm{kDa})$ and Phosphorylase b (94.0 kDa).

Acidification assays. $L$. lactis cells were washed, and concentrated to an $\mathrm{OD}_{620}$ of 1.0 (approx.) in a $5 \mathrm{mM}$ potassium phosphate buffer $\mathrm{pH} 5.8$. For the acidification assay, $4 \mathrm{ml}$ cell suspension was transferred to a stirred, water-jacketed vessel $\left(30^{\circ} \mathrm{C}\right)$, and the $\mathrm{pH}$ was recorded continuously with a $\mathrm{pH}$-electrode. The acidification rate was determined from the slope of the $\mathrm{pH}$ versus time graph, and expressed as $\mathrm{nmol} \mathrm{H} \mathrm{H}^{+} \mathrm{min}^{-1} \mathrm{mg}$ of protein ${ }^{-1}$.

Cell permeabilization assays. To determine permeabilization of $L$. lactis and B. subtilis by detergents the following assays were performed:

(i) lactate dehydrogenase (LDH) activity. $L$. lactis or B. subtilis cells were washed, concentrated 1.5 $x$, and incubated at $30^{\circ} \mathrm{C}$ in $50 \mathrm{mM} \mathrm{KP}{ }_{j} \mathrm{pH} 7$ in the absence and presence of various concentrations of Triton X-100. After 1 hour, cells $(1.0 \mathrm{ml})$ were spun down for $2 \mathrm{~min}$ in an Eppendorf centrifuge, and the supernatant was retained. To determine the total LDH activity the cells $(2 \mathrm{ml})$ were permeabilized by sonification ( $18 \times 15 \mathrm{~s}$ sonification at 1 min intervals at an amplitude of $15 \mu \mathrm{m}$, by a Soniprep 150 ultrasonic disintegrator [SANYO Gallenkamp PLC, Leicester, UK]). During sonification the samples were cooled in icewater. The sample mixture contained $50 \mathrm{mM} \mathrm{KP_{ \textrm {i } }} \mathbf{p H} 7$ buffer, supernatant, and $0.15 \mathrm{mM} \mathrm{NADH}$, and the reaction was started by the addition of $10 \mathrm{mM}$ Pyruvate. The LDH activity was determined by the decrease in absorbance of NADH, measured at $340 \mathrm{~nm}$ in a Beckman DU 64 spectrophotometer (Beckman Instruments CO., USA).

(ii) influx of TOTO-1. $L$. lactis cells were washed and resuspended in $50 \mathrm{mM} \mathrm{KP_{i }}$ pH 7 with $0.5 \mu \mathrm{M}$ TOTO-1 (Molecular Probes Ltd. Oregon, USA). Subsequently, the cell suspensions were incubated in the absence and presence of $0.4 \%$ Triton X-100 or $0.2 \%$ Lauryl sulfobetaine. After 2 hours the fluorescence of TOTO-1 was measured by scanning the emission wavelengths of the cell suspensions between 500 and $600 \mathrm{~nm}$. The excitation wavelength was $488 \mathrm{~nm}$.

(iii) efflux of $\mathrm{cF}$. Cells washed and resuspended in the same volume of $50 \mathrm{mM} \mathrm{KP}$ pH 7.0 were loaded with $\mathrm{cF}$ by incubation $\left(10 \mathrm{~min} 30^{\circ} \mathrm{C}\right)$ in the presence of $22 \mu \mathrm{M} \mathrm{cFDA}$. Hereafter, the cells were washed twice and resuspended in the same volume of $50 \mathrm{mM} \mathrm{KP}, \mathrm{pH} 7$. At time zero the tubes were placed in a water bath at $30^{\circ} \mathrm{C}$ and samples $(200 \mu \mathrm{l})$ were withdrawn at regular time intervals and placed on ice. Cells were spun down immediately for $2 \mathrm{~min}$ in an Eppendorf centrifuge, and 150 $\mu \mathrm{l}$ of the supernatant was pipetted off and diluted with $750 \mu$ l potassium phosphate buffer $\mathrm{pH} 7$. Fluorescence was measured at excitation and emission wavelengths of 490 and $515 \mathrm{~nm}$, respectively (slit widths $2.5 \mathrm{~nm}$ ).

(iv) Determination of intracellular and extracellular ATP. Cells were washed and resuspended in the same volume of $50 \mathrm{mM} \mathrm{KP} \mathrm{iH}_{\mathrm{i}} 7$ (unless otherwise indicated). At time zero, the tubes were placed in a $30^{\circ} \mathrm{C}$ water bath. At various time points, $20 \mu \mathrm{l}$ and $100 \mu \mathrm{l}$ samples were withdrawn to determine the total and extracellular ATP concentration, respectively. The first sample $(20 \mu \mathrm{l})$ was immediately mixed with $80 \mu$ l dimethyl sulfoxide. The second sample $(100 \mu l)$ was spun down immediately for 2 min in an Eppendorf centrifuge, after which $20 \mu \mathrm{l}$ of supernatant was removed and mixed with $80 \mu \mathrm{l}$ dimethyl sulfoxide. All samples were diluted with $5 \mathrm{ml}$ nanopure filtered water. ATP concentrations 
were determined with a Lumac/3M biocounter M 2010 (Perstop Analytical, Oud-Beyerland, The Netherlands) using the Lumac luciferin-luciferase enzyme assay. The enzyme mixture $(100 \mu \mathrm{l})$ was added to $200 \mu \mathrm{l}$ of diluted sample, after which the luminescence was measured. Intracellular ATP concentrations were calculated from the known concentrations of extracellular and total ATP. The total number of cells was determined with a Bürker-Türker cell chamber (depth $0.01 \mathrm{~mm}$ ). The approximation used for the intracellular volume of a single Lactococcal cell $\left(v_{i}\right)$ was taken to be $1 \mu \mathrm{m}^{3}$. (v) Determination of intracellular $\mathrm{pH}$. The intracellular $\mathrm{pH}$ was determined essentially as described previously (3), using the internally conjugated fluorescent $\mathrm{pH}$ probe 5-(and-6)-carboxyfluorescein succinimidyl ester (cFSE). Harvested cells were washed and concentrated $1.5 \mathrm{x}$ in $1 \mathrm{ml}$ potassium HEPES buffer $\mathrm{pH} 8.0$. Subsequently, the cells were incubated $10 \mathrm{~min}$ at $30^{\circ} \mathrm{C}$ in the presence of 1.0 $\mu \mathrm{M}$ cFDASE, washed and resuspended in the same volume of $50 \mathrm{mM} \mathrm{KP}$ i $\mathrm{pH} 7$ (unless otherwise indicated). To eliminate non-conjugated fluorescent probe, lactose (10 $\mathrm{mM}$ final concentration) was added and the cells were incubated for an additional 30 minutes at $30^{\circ} \mathrm{C}$. Cells were then washed twice, resuspended in the same volume of $50 \mathrm{mM} \mathrm{KP} i \mathrm{pH} 7$ and placed on ice until use. For analysis of the intracellular $\mathrm{pH}$, cells containing fluorescent probe were diluted to a concentration of approx. 1 $x 10^{7}$ cells per $\mathrm{ml}$ in a $3 \mathrm{ml}$ glass cuvette and fluorescence was measured using a spectrofluorometer.

Protoplast formation. Protoplasts were obtained as described by Kondo (11), with some modifications. An overnight $L$. lactis suspension was diluted 5 times and incubated for 3 hours at $30^{\circ} \mathrm{C} .1 \mathrm{ml}$ of this culture was washed in cold distilled water and resuspended in $1 \mathrm{ml} 0.01 \mathrm{M}$ Trishydrochloride $\mathrm{pH} 7.0$ containing $0.5 \mathrm{M}$ sucrose. Mutanolysin was added to a final concentration of $25 \mu \mathrm{g}$ per $\mathrm{ml}$ (approx. 100 units $/ \mathrm{ml}$ ), and the cell suspension was incubated for 25 minutes at $37^{\circ} \mathrm{C}$. Protoplast formation was monitored by phase contrast microscopy. The protoplasts were pelleted by centrifugation in an Eppendorf centrifuge and resuspended in $1 \mathrm{ml} \mathrm{SMMB}$ buffer $\mathrm{pH} 6.5(0.5 \mathrm{M}$ sucrose, $0.02 \mathrm{M}$ maleate, $0.02 \mathrm{M} \mathrm{MgCl}_{2}$ and $1 \%$ bovine serum albumin), and placed on ice until required. The intracellular volume of $L$. lactis protoplasts was estimated to be $1.7 \mu \mathrm{m}^{3}$.

Chemicals. Lauryl sulfobetaine was obtained from Calbiochem corp. La Jolla, California, USA. Triton X-100 was obtained from Fluka Chemie AG, Buchs, Switzerland. cFDA and TOTO-1 were obtained from Molecular Probes Inc, Oregon, USA. Mutanolysin was obtained from Sigma-Aldrich B.V., Brussels, Belgium. Lumit-PM (luciferin-luciferase mixture) and Lumit buffer were obtained from Perstop Analytical, Oud-Beyerland, The Netherlands.

\section{Results}

Growth of Lactococcus lactis and Bacillus subtilis in the presence of detergents. Triton X-100 and Lauryl sulfobetaine completely inhibited growth of L. lactis and B. subtilis at 0.013 and $0.025 \%(w / v)$, respectively (Fig. 2). The growth inhibitory concentrations of Triton X-100 and Lauryl sulfobetaine were below their CMC, which are $0.015 \%$ and $0.12 \%$, respectively. Significantly, the $\mathrm{OD}_{620}$ of the $B$. subtilis suspensions decreased below the initial $\mathrm{OD}$, as a result of lysis evidenced by microscopic analysis. In contrast, the $\mathrm{OD}_{620}$ of $L$. lactis suspensions was not decreased in the presence of growth inhibitory concentrations of Triton X-100 and Lauryl sulfobetaine, and lysis was not observed. 


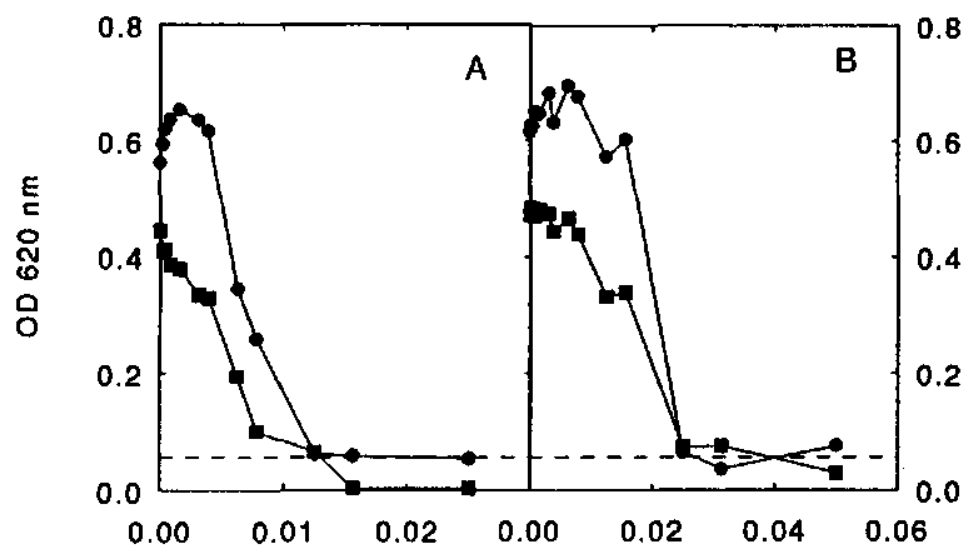

[Triton $X-100](\%) \quad$ [Lauryl sulfobetaine] (\%)

FIG. 2. $\mathrm{OD}_{620}$ of $L$. lactis $(\Theta)$ and $B$. subtilis $(\boldsymbol{Q})$ cultures as a function of increasing concentrations of Triton X-100 (A) and Lauryl sulfobetaine (B), after 5 hours incubation at $30^{\circ} \mathrm{C}$. The dotted line represents the initial $O D$.

Influence of preincubation with detergents on growth of $\boldsymbol{L}$. lactis. In the absence of detergent $L$. lactis cells exhibited growth in M17 broth after a lag period of about $30 \mathrm{~min}$ following one hour preincubation in $50 \mathrm{mM} \mathrm{KP}$ pH 7 (Fig. 3). Preincubation in this buffer in the presence of $0.01 \%$ Triton $X-100$ and subsequent removal of the detergent by washing did not affect the lag period, and the exponential growth rate was comparable to that of the control. However, when the cells were preincubated in the presence of $0.1 \%$ Triton X-100 the lag period was lengthened by 1 hour (approx.). Under these conditions the number of CFU was not affected during the preincubation as determined by plate count (data not shown). In contrast, after preincubation in the presence of Lauryl sulfobetaine $(0.1 \%)$ no growth was observed after transfer to fresh medium, and the number of CFU appeared to be reduced to less than $0.01 \%$ of the initial number.

Analysis of solubilized and cellular proteins by SDS-PAGE. The Protein composition of the extracellular medium was analyzed by SDS-PAGE after 1 hour incubation of L. lactis in the absence and presence of Triton X-100 and Lauryl sulfobetaine at $30^{\circ} \mathrm{C}$ in 50 $\mathrm{mM} \mathrm{KP}$ i 7 (Fig. 4). In the absence of detergent low amounts of some high molecular weight proteins could be observed in the extracellular medium of $L$. lactis. In the presence of $0.01 \%$ Triton X-100 additional bands became evident with molecular weights between 


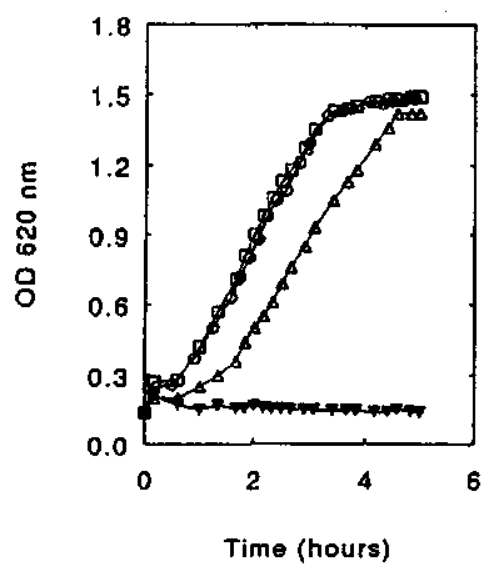

FIG. 3. Effect of preincubation with detergents on growth of $L$. lactis. Cells were preincubated at $30^{\circ} \mathrm{C}$ in potassium phosphate buffer $\mathrm{pH} 7$ for 1 hour in the absence $(O)$, and presence of $0.01 \%$ Triton X-100 ( $\square$ ), $0.1 \%$ Triton X-100 $(\Delta)$, and $0.1 \%$ Lauryl sulfobetaine ( $\nabla)$. Subsequently, the cell suspensions were washed twice and resuspended in M17 broth with lactose $(0.5 \%)$ and incubated at $30^{\circ} \mathrm{C}$.

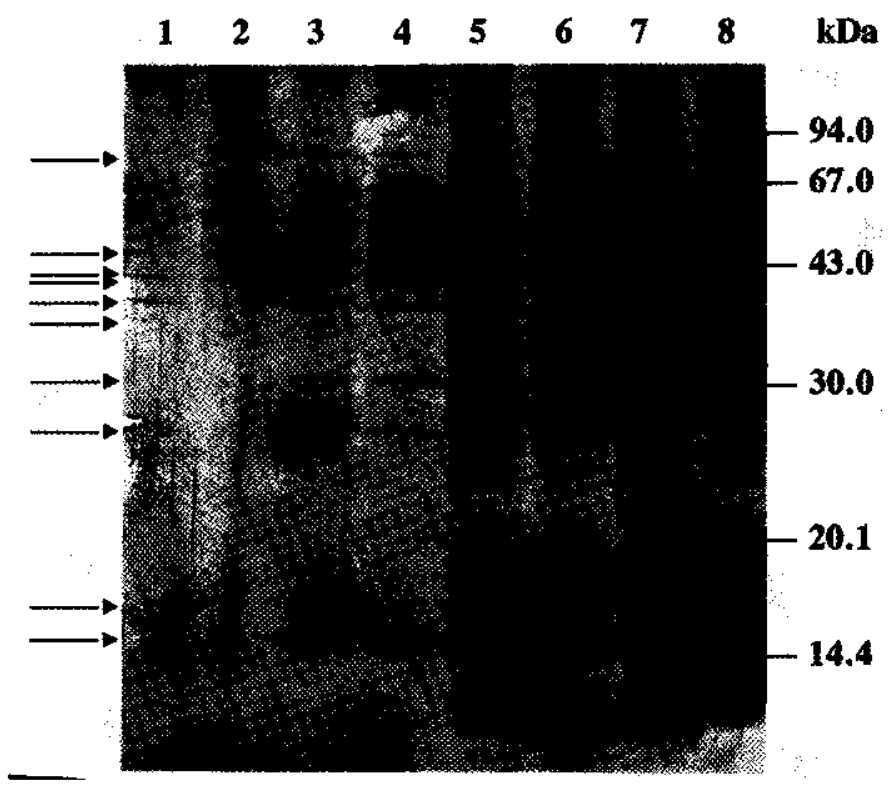

FIG. 4. Protein composition of culture supernatants (lane 1 to 4 ) and cell extracts (lane 5 to 8 ) from $L$. lactis after incubation with detergents. The cells were incubated for 1 hour at $30^{\circ} \mathrm{C}$ in the absence (lane 1 and 5), and presence of $0.01 \%$ Triton X-100 (lane 2 and 6), $0.1 \%$ Triton X-100 (lane 3 and 7 ), and $0.1 \%$ Lauryl suifobetaine (lane 4 and 8 ). Bands of interest are indicated by the arrows. 
40 and $95 \mathrm{kDa}$. In the presence of $0.1 \%$ Triton $\mathrm{X}-100$ a prominent band was detected at about $15 \mathrm{kDa}$ and several minor bands at approx. 17, 28, 32, 39 and $42 \mathrm{kDA}$. Significantly, proteins with similar molecular masses were detected in the growth medium in the presence of Lauryl sulfobetaine $(0.1 \%)$.

Glycolysis. Acidification of the external medium was used as an indication of the glycolysis rate in $L$. lactis. Exposure of cells to levels of Triton X-100 sufficient to inhibit growth, or higher $(0.2 \%)$, did not prevent acidification of the non-buffered medium at $\mathrm{pH}$ 5.8 in the presence of lactose $(10 \mathrm{mM})$. In contrast, Lauryl sulfobetaine $(0.2 \%)$, and the ionophores valinomycin $(1 \mu \mathrm{M})$ and nigericin $(1 \mu \mathrm{M})$ (in combination), completely inhibited extracellular acidification at pH 5.8 (data not shown). These results indicate that Triton $\mathrm{X}-100$ does not interfere with glycolysis in L. lactis, whereas Lauryl sulfobetaine apparently does.

Permeabilization of $L$. lactis and $B$. subtilis. To evaluate the effect of detergents on the integrity of the cell envelope of $L$. lactis and $B$. subtilis, the leakage of cytoplasmic LDH $\left(\mathbf{M}_{\mathrm{w}} \approx 35 \mathrm{kDa}\right)$, the influx of TOTO-1 $\left(\mathrm{M}_{\mathrm{w}} 1303\right)$, the efflux of carboxyfluorescein $\left(\mathbf{M}_{w}\right.$ 376), the leakage and/or consumption of intracellular ATP $\left(M_{w} 507\right)$, and the proton permeability were analyzed in the absence and presence of detergents.

(i) After 1 hour incubation of $L$. lactis in the presence of Triton X-100 $(0.1 \%$ or higher), the LDH activity observed in the extracellular medium was $3.3 \%$ compared to that of cells disrupted by sonification [which was set to $100 \%$ ] (Fig. 5). When lactose $(10 \mathrm{mM})$ was also present, leakage of LDH was significantly decreased to only $0.8 \%$. After 1 hour incubation of $L$. lactis cells in the presence of Lauryl sulfobetaine, no LDH activity could be detected in the extracellular medium. With $B$. subtilis, LDH leakage after one hour incubation of cells in the absence and presence of glucose $(10 \mathrm{mM})$ was 12 and $15 \%$ (approx.), respectively, as compared to LDH released from sonification-disrupted cells. However, when $B$. subtilis was incubated for an additional hour, the LDH activity increased to $80 \%$ (approx.) of permeabilized cells, indicating that the majority of the cells had lysed (data not shown).

(ii) The presence of intracellular TOTO-1 is evident from strong fluorescence between 520 and $560 \mathrm{~nm}$ after its binding to DNA. Hence, fluorescent cells indicate uptake of TOTO-1 resulting from permeabilization of the cytoplasmic membrane. $L$. lactis cells incubated 2 hours in the presence of Lauryl sulfobetaine exhibited strong fluorescence (Fig. 6). This was not evident when Triton X-100 was used. After incubation for 2 hours in the presence of $0.4 \%$ Triton X-100 the fluorescence of the cells was slightly increased, suggesting that only a small percentage (approx. $15 \%$ ) of the cells had become permeable to TOTO-1.

(iii) $\mathrm{cF}$ is well retained intracellularly when $L$. lactis cells are not energized. After addition of lactose $(10 \mathrm{mM})$, efflux of $\mathrm{cF}$ was stimulated $\left(t_{1 / 2},<2 \mathrm{~min}\right)$ [Fig. 7], most likely via an energy dependent efflux system which has previously been shown to transport BCECF (17). Triton X-100 (0.1\%)-induced efflux of cF from non-energized cells ( $t_{1 / 2}$ approx. 4 minutes) 


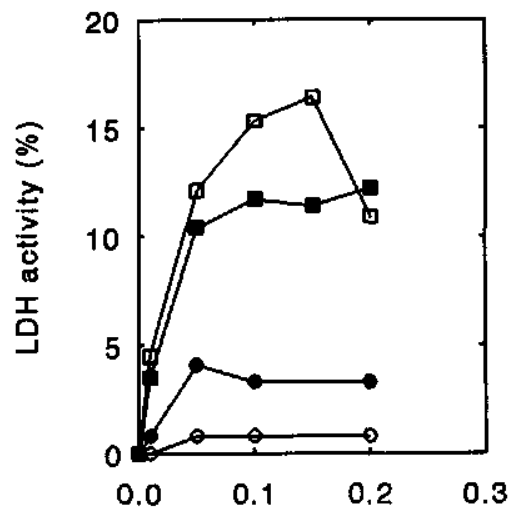

[Triton X-100] (\%)

FIG. 5. Effect of Triton X-100 on release of $\mathbf{L D H}$ from cells of $L$. lactis (circles) and $B$. subtilis (squares). The cells were incubated for 1 hour at $30^{\circ} \mathrm{C}$ in $50 \mathrm{mM}$ potassium phosphate buffer $\mathrm{pH} 7$, in the presence of increasing concentrations of Triton $X-100$. The incubations were performed in the absence (solid symbols), and presence (open symbols) of lactose [10 $\mathrm{mM}]$ (L. lactis), or glucose [10 $\mathrm{mM}$ ( $B$. subtilis). The LDH activity released from cells disrupted by sonification was taken as $100 \%$.

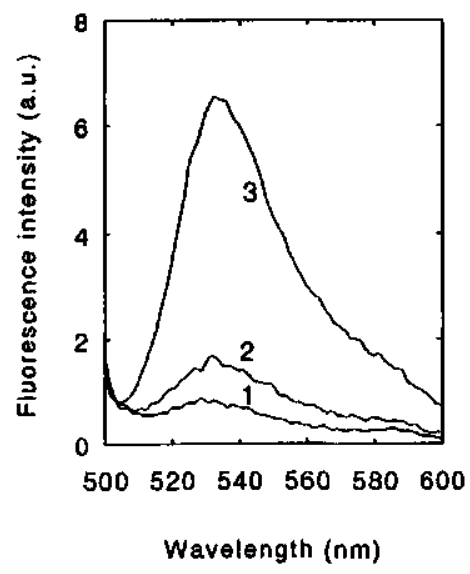

FIG. 6. Effect of detergents on the uptake of TOTO-1 in L. lactis cells. Cell suspensions were incubated 2 hours in the absence (trace 1), and presence of $0.4 \%$ Triton X-100 (trace 2), and $0.2 \%$ Lauryl sulfobetaine (trace 3). The incubations were performed in the presence of TOTO-1 $(0.5 \mu \mathrm{M})$ and the fluorescence spectrum from 500 to $600 \mathrm{~nm}$ was measured with a spectrofluorometer. The excitation wavelength was $490 \mathrm{~nm}$. 


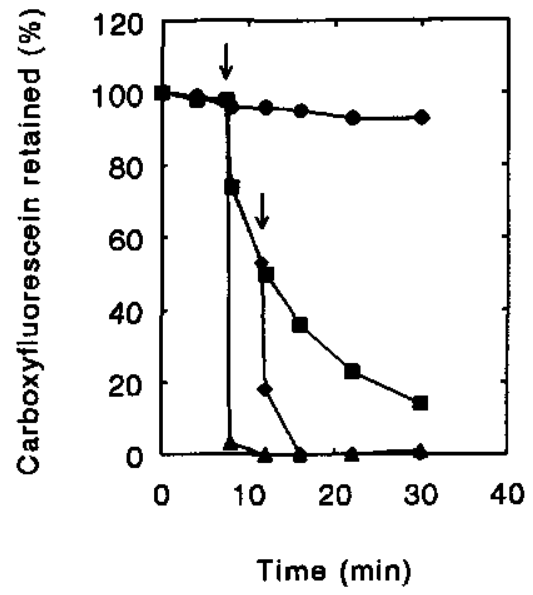

FIG. 7. Effect of Triton $\mathrm{X}-100$ on $\mathrm{cF}$ efflux in L. lactis. Cells were loaded with $\mathrm{cF}$ by $10 \mathrm{~min}$. incubation at $30^{\circ} \mathrm{C}$ with cFDA. The cells were washed and resuspended in $50 \mathrm{mM}$ potassium phosphate buffer ( $\mathrm{pH} \mathrm{7)}$ and $\mathrm{cF}$ efflux was measured at $30^{\circ} \mathrm{C}$ in the absence $(\Theta)$ or the presence of $10 \mathrm{mM}$ lactose ( 4 ), $0.1 \%$ Triton X-100 (ם), $0.1 \%$ Triton X-100 and $10 \mathrm{mM}$ lactose (added at the time indicated by the second arrow) $(\bullet)$. Triton $X-100$ and lactose were added at the time indicated by the first arrow.

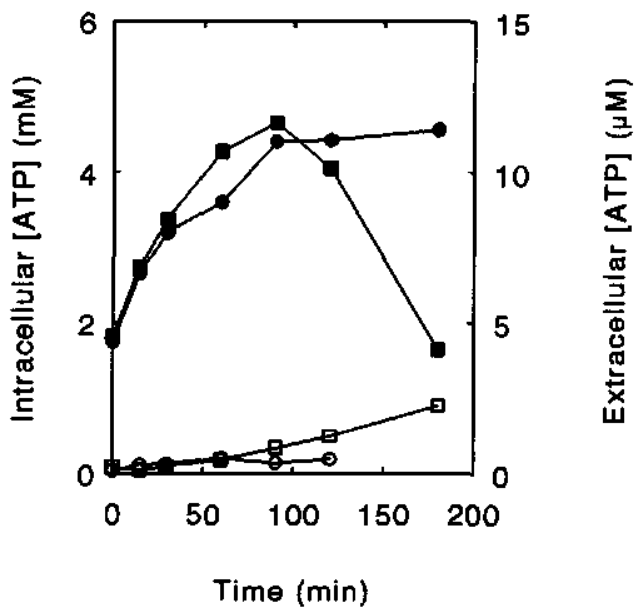

FIG. 8. Intracellular ATP (closed symbols) and extracellular ATP (open symbols) of $L$. lactis cells incubated at $30^{\circ} \mathrm{C}$ in potassium phosphate buffer in the absence $(\bullet)$ and presence of $0.2 \%$ Triton $\mathrm{X}-100(\mathbf{\square})$. 


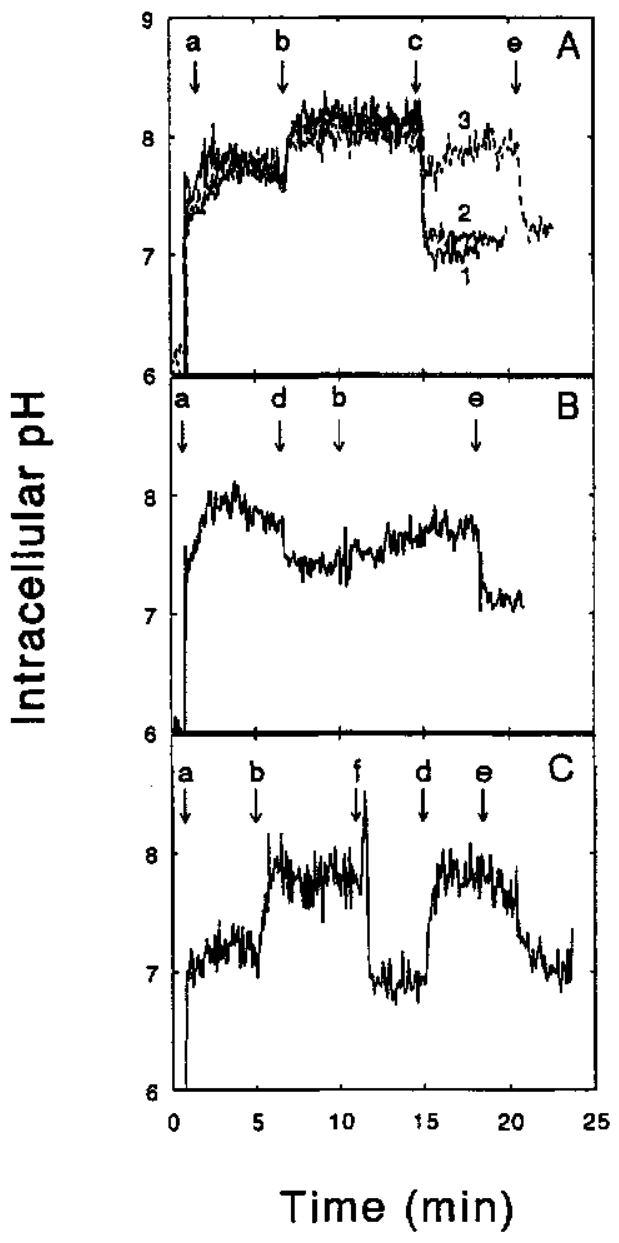

FIG. 9. Effect of detergents on intracellular $\mathrm{pH}$ of $L$. lactis. Cell suspensions were incubated at $30^{\circ} \mathrm{C}$. The following additions were made at the times indicated by the arrows: (a) cell suspension $(100 \mu \mathrm{l})$, (b) lactose $(10 \mathrm{mM})$, (c) Triton $\mathrm{X}-100(0.2 \%)$ (trace 1$)$, nigericin $(1 \mu \mathrm{M})$ (trace 2), and Lauryl sulfobetaine $(0.2 \%)$ (trace 3$)$, (d) Triton X-100 (0.2\%), (e) Lauryl sulfobetaine $(0.2 \%)$, and (f) valinomycin $(1 \mu \mathrm{M})$ and nigericin $(1 \mu \mathrm{M})$. 
suggested permeabilization of cells. Surprisingly, upon addition of lactose to Triton X-100treated cells, cF efflux was significantly stimulated indicating that cells had not been permeabilized by Triton $X-100$.

(iv) The effect of Triton X-100 $(0.2 \%)$ on the intracellular ATP concentration of $L$. lactis resuspended in $50 \mathrm{mM} \mathrm{KP} \mathrm{pH}_{\mathrm{i}} 7(+10 \mathrm{mM}$ lactose) was negligible during the first two hours of exposure. After this period, the intracellular ATP concentration started to decrease and at the same time the extracellular ATP concentration slightly increased (Fig. 8). In control cells to which Triton X-100 had not been added, the intracellular ATP concentration remained high and no extracellular ATP was found. This indicates that after prolonged incubation with Triton X-100 some permeabilization of the cells may have occurred. When the cells were resuspended in fresh M17 broth, the amount of ATP increased significantly during the first hour, presumably concomitant with growth. Such an increase of ATP was not observed in the presence of Triton X-100 $(0.2 \%)$ [data not shown], which is in agreement with the previously observed inhibition of growth in the presence of Triton $\mathrm{X}-100$.

(v) In L. lactis a $\mathrm{pH}$ gradient of approximately 1 unit was generated after addition of lactose $(10 \mathrm{mM})$ to cells in $50 \mathrm{mM} \mathrm{KP} \mathrm{i}_{\mathrm{pH}} 7$ (Fig. 9A). Lauryl sulfobetaine $(0.2 \%)$ dissipated this $\Delta \mathrm{pH}$ effectively, and the same was observed after addition of the $\mathrm{K}^{+} / \mathrm{H}^{+}$ exchanger nigericin $(1 \mu \mathrm{M})$. Upon addition of Triton X-100 $(0.2 \%)$ a transient decrease of approx. $0.2 \mathrm{pH}$ units was observed, after which the $\mathrm{pH}_{\text {in }}$ increased again to 7.9. Subsequent addition of Lauryl sulfobetaine $(0.2 \%)$ to these cells dissipated the $\mathrm{pH}$ gradient completely (Fig. 9A). When $L$. lactis cells were incubated in the absence of lactose the $\mathrm{pH}_{\text {in }}$ initially increased to $\mathrm{pH} 7.9$ and then started to decrease (Fig. 9B). Addition of Triton X-100 $(0.2 \%)$ to these cells abruptly decreased the $\mathrm{pH}_{\text {in }}$ from $\mathrm{pH} 7.8$ to $\mathrm{pH} 7.4$, but addition of lactose resulted in a slow recovery of the $\mathrm{pH}$ gradient. When Triton X-100 $(0.2 \%)$ was added to lactose-energized cells in which the $\mathrm{pH}$ gradient was previously dissipated by addition of nigericin, an increase in the $\mathrm{pH}_{\text {in }}$ was observed (Fig. 9C), suggesting that the uncoupling effect of nigericin is neutralized by Triton $\mathrm{X}-100$, presumably by removing nigericin from the cytoplasmic membrane. The $\mathrm{pH}$ gradient was dissipated when, finally, Lauryl sulfobetaine $(0.2 \%)$ was added. In $B$. subtilis the $\mathrm{pH}$ gradient was dissipated by low detergent concentrations $(<0.03 \%$ for Triton X-100 and Lauryl sulfobetaine [data not shown]).

Effect of detergents on $L$. lactis Protoplasts. The previous results indicate that intact $L$. lactis cells were not or only slightly permeabilized by Triton X-100. Therefore, the role of the cell wall was investigated by analyzing the permeabilization of protoplasts by detergents. In contrast to intact cells, protoplasts showed an immediate decrease of intracellular ATP upon addition of Triton X-100 (0.2\%), which was accompanied by a transient increase of the extracellular ATP concentration (Fig. 10). Lauryl sulfobetaine elicited a similar effect (data not shown). 


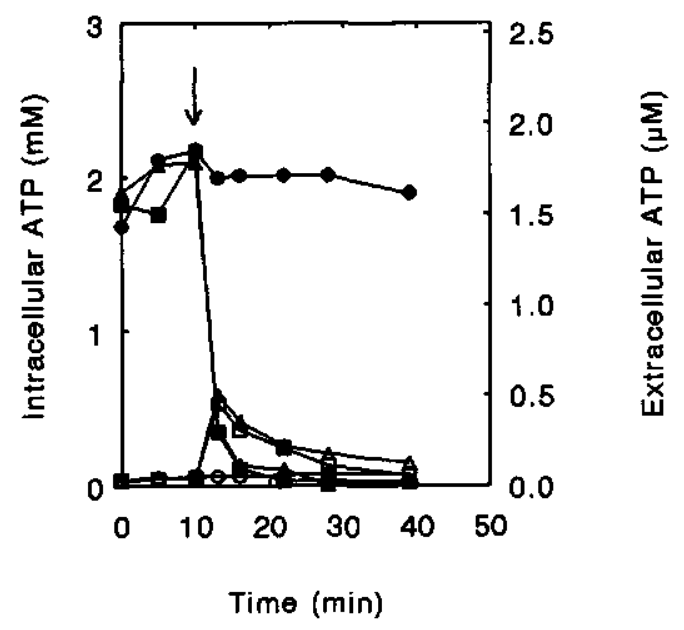

FIG. 10. Intracellular ATP concentrations (closed symbols) and extracellular ATP concentrations (open symbols) of $L$. lactis protoplasts incubated at $30^{\circ} \mathrm{C}$ in SMMB buffer $\mathrm{pH} 6.5$ in the absence (ब) and presence of $0.2 \%$ Triton X-100 (ם), or $0.1 \%$ SDS ( $\triangle)$. The detergents were added at the time indicated by the arrow.

\section{Discussion}

Triton X-100 and Lauryl sulfobetaine efficiently inhibited growth of $L$. lactis and $B$. subtilis at concentrations below their critical micelle concentrations. The general concept for the effect of detergents on intact biological membranes is that, when the detergent/lipid ratio is sufficiently high (i.e. greater than approx. 2 in case of Triton X-100), proteins and lipids are solubilized from the membrane, and as a result the permeability for ions and proteins is increased $(7,8,10)$. Assuming that the lipid fraction of $L$. lactis cells is between 2.5 to 7.5 $\%$ of the cellular dry weight, the detergent/lipid ratio in a cell suspension of $\mathrm{OD}_{620} 0.7$ (i.e. approx. $1 \times 10^{9}$ bacteria per $\mathrm{ml}$ ) with $0.01 \%$ Triton $\mathrm{X}-100$ (which is the growth inhibiting concentration for $L$. lactis) was estimated to be between 3.5 to 10 . The cytoplasmic membrane of energized L. lactis is, however, not permeabilized by Triton X-100 as demonstrated by (a) acidification of the extracellular medium by $L$. lactis after addition of lactose to the cells in the presence of Triton $X-100$, indicating that the lactose uptake 
system and the glycolytic enzymes functioned normally, (b) maintenance of high intracellular ATP levels in the presence of Triton X-100, (c) negligible LDH activity in the extracellular medium after 1 hour incubation in the presence of Triton X-100, and (d) maintenance of a $\mathrm{pH}$ gradient in the presence of high concentrations of Triton X-100 $(0.2 \%)$. Strikingly, Triton $\mathrm{X}-100$-induced efflux of $\mathrm{cF}$ from $L$. lactis was strongly accelerated upon addition of lactose, indicating that this effect of Triton X-100 is not likely to be due to cell permeabilization, but is caused by another mechanism. Energy-dependent efflux of fluorescein derivatives such as $\mathrm{cF}$, $\mathrm{CFSE}$ and BCECF has been described in $L$. lactis $(3,17)$, and it may be possible that Triton X-100 acts as a non-specific trigger of an existing cF extrusion system. Recently, in Corynebacterium glutamicum the carrier-mediated extrusion of glutamate was shown to be increased by local anesthetics such as tetracaine and chlorpromazine, presumably by a change in membrane order, which in turn activated the transport system (13). Whether similar mechanisms are involved in the Triton X-100induced extrusion of fluorescein derivatives in $L$. lactis remains to be elucidated.

An important point is the resistance of $L$. lactis to permeabilization by Triton X-100. In general, the cell envelope provides the first defence of cells against the external environment. In gram-negative bacteria the cell envelope consists of two membranes, the cytoplasmic membrane and the outer membrane, which are separated by a peptidoglycan containing periplasm. It is known from earlier studies that the lipopolysaccharide-outer membrane layer and the attached peptidoglycan layer isolated from Escherichia coli are not solubilized by Triton X-100 (21), and that the principal site of attack of Triton X-100 appeared to be the cytoplasmic membrane (20). Furthermore, it has been demonstrated that lipopolysaccharide incorporated into phospholipid bilayers protected these artificial membranes from disruption by the nonionic detergent deoxycholate (19). Gram-positive bacteria do not possess an outer membrane, but do have a significant peptidoglycan layer. Our results showed that $L$. lactis protoplasts, lacking the peptidoglycan layer, were very sensitive to permeabilization by Triton X-100, suggesting that it is indeed the cell wall which is functioning as a protective barrier against Triton X-100. In contrast, the grampositive $B$. subtilis was readily lysed by Triton $X-100$. Previous results demonstrated that the detergent-induced lysis resulted from deregulation of autolysin activity (24). Furthermore, Jolliffe et al. (9) suggested that activation of autolytic enzymes in $B$. subtilis could be triggered by a decrease of the transmembrane proton motive force. Since Triton X-100 effectively dissipated the $\mathrm{pH}$ gradient in B. subtilis (data not shown), this may have triggered autolysis. Triton X-100-induced autolysis has also been described in Streptococcus faecalis cells (5). In L. lactis a gene ( $a m c A$ ) encoding for a peptidoglycan hydrolase has been identified, and it has been shown that this autolytic activity is required for cell separation (4). Lysis of $L$. lactis cells in the exponential growth phase, however, was not triggered by Triton X-100, and this may be correlated to maintenance of the proton motive force under these conditions. 
It has been reported that several bacteria possess energy-dependent defence mechanisms against detergents. Halobacterium cutirubrum cells were resistant to Triton X-100 (0.15\%), but were readily lysed by this detergent in the presence of respiratory inhibitors such as KCN (14). Enterobacter cloacae was shown to require ATP for maintenance of cellular integrity in the presence of SDS (1). Clinical isolates of Staphylococcus aureus were reported to contain several genes ( $q a c$ genes) encoding for proton motive force driven extrusion systems, conferring resistance to cationic, lipophilic compounds such as quaternary ammonium compounds (qac) and ethidium bromide (15). Related multidrugresistance systems have recently been found in L. lactis (2). At present, it is not known whether this class of extrusion systems may confer resistance to nonionic detergents. Our results show that in L. lactis an energy source (lactose) was necessary to restore the $\mathrm{pH}$ gradient after addition of Triton X-100. Moreover, addition of lactose to exponential phase $L$. lactis cells in the presence of Triton X-100 prevented to a large extent leakage of LDH to the extracellular environment. An energy requirement for Triton X-100 resistance was also suggested by the depletion of the intracellular ATP pool after prolonged incubation in the presence of Triton X-100. However, energy-depleted cells of $L$. lactis incubated for 1 hour in the presence of Triton X-100 were still viable as was demonstrated by plate counts, and when these cells were subsequently resuspended in fresh medium growth was rapidly restored. It may be possible that Triton X-100 induces minor permeabilization, and that metabolic energy is required to counteract these effects. It can not be ruled out that energydependent extrusion systems play a role in resistance of $L$. lactis to Triton $X-100$, but resistance to this detergent solely by use of an energy-dependent extrusion system is not very likely.

The mechanism by which Triton X-100 inhibits growth of $L$. lactis is not well understood. As discussed above, energized exponential phase $L$. lactis cells were not permeabilized by Triton X-100. Furthermore, $L$. lactis still showed significant uptake of 2-amino-isobutyric acid (a non-metabolizable analog of L-alanine) and L-glutamate in the presence of Triton X-100 (data not shown), indicating that uptake of (essential) amino acids is not a limiting factor for growth. The increased ATP consumption in $L$. lactis in the presence of Triton X-100 may explain to some extent the inhibition of growth. Alternatively, when L. lactis was incubated in the presence of Triton X-100 several proteins were released into the extracellular medium. These proteins are most likely cell wall associated. Gram-positive bacteria do contain various cell wall associated enzymes such as carboxypeptidases, transpeptidases and hydrolases (22). Transpeptidases are involved in cell wall assembly and are susceptible to inhibition by B-Lactam antibiotics (e.g. penicillin). The peptidoglycan hydrolases (autolysins), are thought to be involved in cell wall turnover, cell separation and various other functions $(4,6,22,23)$. The involvement of autolysins in growth inhibition of exponential phase $L$. lactis cells seems not very likely, since neither the characteristic formation of long filaments (4) nor lysis was observed. The rapid recovery of growth of 
L. lactis after removal of Triton $\mathrm{X}-100(0.01 \%)$ indicates that de novo protein synthesis is not required at this low concentration. It is possible that Triton X-100 directly inhibits enzymes involved in cell wall assembly. A short exposure to higher Triton X-100 concentrations $(0.1 \%$ ), resulted in an increase of the lag time to $1 \mathrm{~h}$ (approx.). It is conceivable that proteins which are released from the cells under these conditions are essential for growth, and that their loss results in growth inhibition of $L$. lactis.

In conclusion, Triton X-100 does not permeabilize actively growing $L$. lactis cells, although growth is inhibited. The resistance is likely to be mediated by the cell envelope, but includes the requirement of metabolic energy. Future research will focus on the exact mechanism by which Triton X-100 inhibits growth of $L$. lactis.

\section{Acknowledgments}

We thank Johan van der Vlag for critical reading of the manuscript.

\section{References}

1. Aspedon, A., and K.W. Nickerson. 1994. The energy dependence of detergent resistance in Enterobacter cloacae: a likely requirement for ATP rather than a proton gradient or a membrane potential. Canadian J. Microbjol. 40:184-191.

2. Bolhuis, H., D. Molenaar, G. Poelarends, H.W. van Veen, B. Poolman, A.J.M. Driessen, and W.N. Konings. 1994. Proton motive force-driven and ATP-dependent drug extrusion systems in multidrug-resistant Lactococcus lactis. J. Bacteriol. 176:6957-6964.

3. Breeuwer, P., J.L. Drocourt, F.M. Rombouts, and T. Abee. 1996. A novel method for continuous determination of the intracellular $\mathrm{pH}$ in bacteria using the internally conjugated probe 5-(and-6)-carboxyfluorescein succinimidyl ester. Appl. Environ. Microbiol. 62:178-183.

4. Buist, G. J. Kok, K.J. Leenhouts, M. Dabrowska, G. Venema, and A.J. Haandrikman. 1995. Molecular cloning and nucleotide sequence of the gene encoding the major peptidoglycan hydrolase of Lactococcus lactis, a muramidase needed for cell separation. J. Bacteriol. 177:1554-1563.

5. Cornett, J.B., and G.D. Shockman. 1978. Cellular lysis of Streptococcus faecalis induced with Triton X100. J. Bacteriol. 135:153-160.

6. Doyle, R.J., J. Chaloupka, and V. Vinter. 1988. Turnover of cell walls in micro-organisms. Microbiol. Rev. 52:554-567.

7. Helenius, A., and H. Söderlund. 1973. Stepwise dissociation of the semliki forest virus membrane with Triton X-100. Biochim. Biophys. Acta 307:287-300.

8. Helenius, A., and K. Simons. 1975. Solubilization of membranes by detergents. Biochim. Biophys. Acta. 415:29-79.

9. Jolliffe, L.K., R.J. Doyle, and U.N. Streips. 1981. The energized membrane and cellular autolysis in Bacillus subtilis. Cell 25:753-763. 
10. Kirkpatrick, F.H., S.E. Gordesky, and G.V. Marinetti. 1974. Differential solubilization of proteins, phospholipids and cholesterol of erythrocyte membrane by detergents. Biochim. Biophys. Acta 345:154-161.

11. Kondo, J.K., and L.L. McKay. 1984. Plasmid transformation of Streptococcus lactis protoplasts: optimization and use of molecular cloning. Appl. Environ. Microbiol. 48:252-259.

12. Laemmli, U.K. 1970. Cleavage of the structural proteins during the assembly of the head bacteriophage T4. Nature 227:680-685.

13. Lambert, C. A. Erdmann, M. Eikmanns, and R. Krämer. 1995. Triggering glutamate excretion in Conynebacterium glutamicum by modulating the membrane state with local anesthetics and osmotic gradients.

14. Lanyi, J.K. 1973. Influence of electron transport on the interaction between membrane lipids and Triton X100 in Halobacterium cutirubrum. Biochem. 12:1433-1438.

15. Littlejohn. T.G., I.T. Paulsen, M.T. Gillespie, J.M. Tennent, M. Midgley, I. G. Jones, A.S. Purewal, and R. Skurray. 1992. Substrate specificity and energetics of antiseptic and disinfectant resistance in Staphylococcus aureus. FEMS Microbiol. Lett. 95:259-266.

16. Miozzari, G.F., P. Niederberger, and R. Hütter. 1978. Permeabilization of microorganisms by Triton X100. Anal. Biochem. 90:220-233.

17. Molenaar, D., H. Bolhuis, T. Abee, B. Poolman, and W.N. Konings. 1992. The efflux of a fluorescent probe is catalyzed by an ATP-driven extrusion system in Lactococcus lactis. J. Bacteriol, 174:3118-3124.

18. Morrissey, J.H. 1981. Silver stain for proteins in polyacrylamide gels: a modified procedure with enhanced uniform sensitivity. Anal. Biochem. 117:307-310

19. Nixdorff, K., J. Gmeiner, and H.H. Martin. 1978. Interaction of lipopolysaccharide with detergents and its possible role in the detergent resistance of the outer membrane of Gram negative bacteria. Biochim. Biophys. Acta 510:87-98.

20. Schnaitman, C.A. 1971. Solubilization of the cytoplasmic membrane of Escherichia coli by Triton X-100. J. Bacteriol. 108:545-552.

21. Schnaitman, C.A. 1971. Effect of ethylenediaminetetraacetic acid, Triton X-100, and lysozyme on the morphology and chemical composition of isolated cell walls of Escherichia coli. J. Bacteriol. 108:553-563.

22. Shockman, G.D., and J.F. Barrett. 1983. Structure, function and assembly of cell walls of gram-positive bacteria. Ann. Rev. Microbiol. 37:501-527.

23. Tomasz, A. 1984. Building and breaking of bonds in the cell wall of bacteria - the role for autolysins. p. 311. In C. Nombela (ed.), Microbial cell wall synthesis and autolysis. Elsevier Science Publishers, Amsterdam, The Netherlands.

24. Tsuchido, T., A. Svarachorn, H. Saga, and M. Takano. 1990. Lysis and aberrant morphology of Bacillus subtilis cells caused by surfactants and their relation to autolysin activity. Antimicrob. Agents Chemother. 34:781-785.

25. Van der Werf, M.J., S. Hartmans, and W.J.J. van den Tweel. 1995. Permeabilization and lysis of Pseudomonas pseudoalcaligenes cells by Triton X-100 for efficient production of D-malate. Appl. Microbiol. Biotechnol. 43:590-594.

26. Womack, M.D., D.A. Kendall, and R.C. MacDonald. 1983. Detergent effects on enzyme activity and solubilisation of lipid bilayer membranes. Biochim. Biophys. Acta 733:210-215. 


\section{7}

\section{General Discussion}

Part of this chapter will be submitted for publication as a review entitled "Assessment of viability of microorganisms employing fluorescence techniques", by P. Breeuwer and T. Abee. 


\section{Introduction}

The methods investigated in this thesis to assess the viability of microorganisms are principally based on: (i) energy-dependent efflux of fluorescent probes, and (ii) determination of the intracellular $\mathrm{pH}\left(\mathrm{pH}_{\mathrm{in}}\right)$. During the last years, evidence has accumulated that extrusion of fluorescent probes from microorganisms is mediated by MDR transport systems. These systems may frustrate labelling of microorganisms with fluorescent probes including DNA/RNA labelling, assessment of the $\mathrm{pH}_{\text {in }}$, and determination of the membrane potential. On the other hand, the ability of microorganisms to extrude fluorescent probes or their precursors may be correlated to the energy metabolism of the cells. The significance of energy-dependent transport systems with regard to cell viability is discussed in more detail. The $\mathrm{pH}_{\mathrm{in}}$ is critical for the control of many cellular processes, including DNA transcription, protein synthesis and enzyme activities. In this discussion, the potential of the $\mathrm{pH}_{\text {in }}$ as an indicator of cell viability is evaluated. Finally, it is more and more recognized that cell populations are not homogeneous, and that cells may have different sizes, respiration rates, $\mathrm{pH}_{\mathrm{in}}$ values, etc. (22). The application of fluorescent techniques for analysis of population heterogeneity is discussed.

\section{Energy-dependent efflux of fluorescent probes}

A number of fluorescent probes or non-fluorescent precursors including fluorescein, $\mathbf{c F}$, BCECF, cFSE, Rhodamine 6G, and ethidium bromide can be extruded from microorganisms by energy-dependent transport systems $(4,5,7,9,28,30,32,36,41$,Chapter 3$)$. Significantly, the positively charged rhodamine and ethidium are extruded by multidrug resistance (MDR) proteins. These proteins have been described in mammalian cells, yeasts and bacteria. At this moment, MDR proteins can be classified into at least four families $(2,5,26,33)$ : (i) ATP binding cassette (ABC) proteins or traffic ATPases. These transporters share several properties: they are inhibited by verapamil and reserpine, the mode of energization is ATP-dependent, and they have two hydrophobic domains comprised of six putative membrane-spanning helices and two hydrophilic domains, which share a conserved region of about 200 amino acids $(2,12)$. The P-glycoprotein or MDR-1 protein found in mammalian cells is the most prominent member of this superfamily, and catalyzes the ATPdependent export of structurally unrelated drugs such as anthracyclines, gramicidin D, valinomycin, and fluorescent compounds or non-fluorescent precursors such as Rhodamine 123, Rhodamine 6G, and BCECF-AM $(17,23)$. A possible bacterial analog of the $m d r$ gene of mammalian cells was reported to be present in Streptomyces peutecius, the producer of the antitumor agents daunorubicin and doxorubicin (16). Very recently, a bacterial homologue of P-glycoprotein has been detected in Lactococcus lactis by van Veen et al. 
(41); (ii) Major Facilitators Superfamily (MFS). MFS proteins are composed of either 12 or 14 putative membrane-spanning helices (34), and use the proton motive force as energy source (26). Examples are the ethidium bromide resistance systems described in Bacillus subtilis (32) and L. lactis (4,5); (iii) Small MDR proteins or Staphylococcal multidrug resistance (Smr) family. This relatively new gene family encodes for small proteins which have only four putative membrane-spanning helices, and are proton-motive force driven $(15,26,42)$. An example is the $s m r$ gene found in Staphylococcus aureus, which encodes for a protein of 107 amino acids. When this gene was expressed in $E$. coli KO1489, the cells exhibited rapid efflux of tetraphenyl phosphonium (TPP ${ }^{+}$) ions and ethidium bromide (15); and (iv) Resistance-Nodulation-Division (RND) family. It is thought that these tranporters consist of cytoplasmic proteins which are linked by accessory proteins to outer membrane channels of gram-negative bacteria, thus allowing direct transport of compounds to the external medium $(33,37)$.

The physiological function of MDR proteins in microorganisms is not well understood. The most obvious role is that of extrusion of (toxic) compounds encountered in the natural habitat to the extracellular environment, but reports which describe the efflux of natural substrates of MDR proteins are very scarce (26). In Pseudomonas aeruginosa, an outer membrane protein of $50 \mathrm{kDA}$ which is responsible for the secretion of pyoverdin, an iron chelator produced by the cell, also conferred resistance to various antibiotics such as tetracycline, chloramphenicol, and streptonigrin (35). Streptomyces pristinaspiralis, produces two antibiotics with synergistic activities, together known as pristinamycin. The gene (ptr) responsible for torelance of this organism to its own antibiotics was described by Blanc et al. (3). ptr encodes for a putative membrane protein with 14 membrane-spanning domains. In addition to pristinamycin, $p t r$ also mediates resistance to rifampicin. Interestingly, it was suggested that the promotor Pptr, which controls the expression of ptr in this organism, could be activated in response to physiological stresses associated with decreases in growth rate (38), and not only by the substrates of the multidrug transporter.

Whether the BCECF, cFSE and $\mathrm{cF}$ efflux system(s) described in $S$. cerevisiae (7,Chapter 3$)$ and $L$. lactis $(9,30$, Chapter 4$)$ can be classified as a multidrug transporter remains to be established. Fluorescein derivatives are negatively charged at physiological $\mathrm{pH}$, whereas MDR substrates are in most cases positively charged or neutral. Transport of $\mathrm{cF}$ in $\boldsymbol{S}$. cerevisiae is not inhibited by verapamil and reserpine $(8$, Chapter 2$)$, and in L. lactis known substrates of the P-glycoprotein such as daunomycin, vinblastin and actinomycin D are not extruded by the BCECF system $(4,30)$. At this moment, information about the homology with existing $A B C$, MFS, and other known genes encoding for transport systems is not available. Interestingly, van Veen et al. (41) reported that the substrate specificity of the BCECF transporter of $L$. lactis is remarkably similar to that of the multidrug resistanceassociated protein (MRP). MRP is an ATP-dependent efflux pump which confers resistance in human cancer cells to a range of drugs including doxorubicin, daunorubicin, vincristine, 
and Rhodamine $123(11,43)$. Müller et al. (31) demonstrated that MRP is very similar, if not identical, to the glutathion $S$-conjugate export carrier (GS-X pump). The ATP-dependent GS-X pump is known to confer resistance in cancer cells to hydrophobic, in most cases negatively charged compounds, including a range of chemotherapeutic drugs such as cisplatin, nitrogen mustards, and chloroethyl nitrosoureas $(1,19,20,31)$. In L. lactis glutathion is present in relatively high concentrations, and it is speculated that the BCECF transporter may be involved in excretion of oxidized glutathion during oxygen stress (41).

Since extrusion of fluorescent compounds by transport systems is coupled to the energy metabolism of the cells, this property can potentially be used for assessment of cell viability. In our laboratory a two-step procedure was developed, whereby Saccharomyces cerevisiae cells were first loaded with $\mathrm{cF}$ by incubation with $\mathrm{cFDA}$, followed by determination of the efflux of $\mathrm{cF}$ in glucose-energized cells (7,Chapter 3 ). In viable cells, the fluorescence intensity decreased as a result of $\mathrm{cF}$ extrusion to the extracellular environment. Heat treated cells $\left(90 \mathrm{~s}, 60^{\circ} \mathrm{C}\right.$ ) lost their ability to export $\mathrm{cF}$, and remained fluorescent. Cells treated with benzoic acid or dinitrophenol were deenergized and showed decreased ability to extrude $\mathrm{cF}$. This extrusion of probe was, however, stimulated upon addition of glucose. The extrusion of $\mathrm{cF}, \mathrm{cFSE}$ and BCECF from Lactococcus lactis cells is most likely driven by an ATP-dependent transport system $(10,30)$, but for this bacterium the relationship of probe efflux with cell viability has not yet been investigated.

The characterization of MDR-like extrusion systems and their relation to cell viability are great challenges for future research. Assessment of viability based on extrusion of fluorescent probes has the significant advantage that it is fast, easy, and allows analysis of individual cells with flow cytometry or image analysis.

\section{The intracellular pH as indicator of viability}

Microorganisms (such as acidophiles, neutrophiles and alkalophiles) can exhibit a wide range of $\mathrm{pH}_{\mathrm{in}}$ values (typically from 5.6 to 9) (6). Under normal growth conditions, the $\mathrm{pH}_{\text {in }}$ of acidophiles and neutrophiles is in general higher than the extracellular pH. In addition to the membrane potential $(\Delta \Psi)$, microorganisms may use this $\mathrm{pH}$ gradient as a driving force for various energy-requiring processes such as the uptake of amino acids and sugars, the rotation of flagella, and the synthesis of ATP. Imai et al. (17) demonstrated that the $\mathrm{pH}_{\text {in }}$ of $S$. cerevisiae cells is correlated with viability. They showed that viable (dividing) yeast cells are capable of maintaining a $\mathrm{pH}$ gradient when incubated at low $\mathrm{pH}(\mathrm{pH} 3)$, whereas non-proliferative cells are not. Also in bacteria, the $\mathrm{pH}_{\mathrm{in}}$ is an important viability parameter. In Streptococcus faecalis, Kobayashi and Unemoto (24) demonstrated that the growth rate was directly coupled with maintenance of an alkaline $\mathrm{pH}_{\text {in }}$. In ATPase-mutants strains, which were defective in their capacity to extrude protons, the growth rate was 
rapidly reduced when the extracellular $\mathrm{pH}$ was decreased. Foster and co-workers $(13,14,25)$ showed that Salmonella typhimurium can actively adapt to potentially lethal acid exposure by induction of different acid tolerance response systems. They showed that survival of this organism is related to an increased ability to maintain a sufficiently high $\mathrm{pH}_{\mathrm{in}}$ and/or DNArepair, synthesis of chaperonins and replacement of acid-sensitive cell constituents with acid-stable homologs. Recently, van de Vossenberg et al. (40) demonstrated that the maximum growth temperature of microorganisms, which use a proton gradient for energy transduction, is most likely determined by the proton permeability of their cytoplasmic membrane. Consequently, to grow at higher temperatures, these microorganisms either should increase the rate of proton pumping or alter the membrane composition such that the membrane becomes less permeable to protons. In our laboratory the effect of heat treatment on proton permeability of bacteria was investigated by measurement of the $\mathrm{pH}_{\text {in }}$. When the temperature is gradually increased to $54^{\circ} \mathrm{C}, L$. lactis subsp. lactis cells could maintain a pH gradient up to approx. $42^{\circ} \mathrm{C}$ (Fig. 1). Interestingly, this temperature is indeed close to the maximum growth temperature of $L$. lactis $\left(40\right.$ to $44^{\circ} \mathrm{C}$ ). In a second experiment, $L$. lactis cells were exposed to $60^{\circ} \mathrm{C}$ up to $4 \mathrm{~min}$ prior to the measurement of the $\mathrm{pH}_{\text {in }}$ [performed at $30^{\circ} \mathrm{C}$ ] (Fig 2). In control cells, which were not exposed to $60^{\circ} \mathrm{C}$, the $\mathrm{pH}_{\text {in }}$ increased upon addition of lactose to 7.5 (approx.). To dissipate the proton motive force valinomycin and nigericin were added. In general, upon addition of valinomycin the membrane potential is dissipated, which is compensated for by an increase of the $\mathrm{pH}$ gradient in the non-treated cells. After exposure for $1 \mathrm{~min}$ at $60^{\circ} \mathrm{C}$ the cells were still able to maintain a pH gradient. However, addition of valinomycin to these cells did not induce an increase of the pH gradient. After $4 \mathrm{~min}$ exposure at $60^{\circ} \mathrm{C}$ no $\mathrm{pH}$ gradient could be observed, which suggests that after this treatment these cells were no longer viable. Indeed, no CFU could be detected by plate count (10).

In conclusion, the $\mathrm{pH}_{\text {in }}$ is potentially a valuable parameter for assessment of cell viability. It may be expected that the increasing possibilities to assess the $\mathrm{pH}_{\text {in }}$ of individual cells under severe stress conditions by flow cytometry or image analysis, will provide new insights in the regulation and maintenance of the $\mathrm{pH}_{\mathrm{in}}$ in microorganisms and the correlation of this parameter with cell viability.

\section{Viability and heterogeneity}

Heterogeneity of a cell population may arise from (i) cells at different stages of growth (i.e. in a population, cells may be in the lag phase, actively growing and dividing, in the stationary phase, or dead), (ii) oscillatory intracellular dynamics such as protein turnover, glycolysis rate, and regulation of redox state, (iii) differences in environmental conditions of individual cells, such as a dissimilar availability of limiting nutrients $(22,27)$. With 


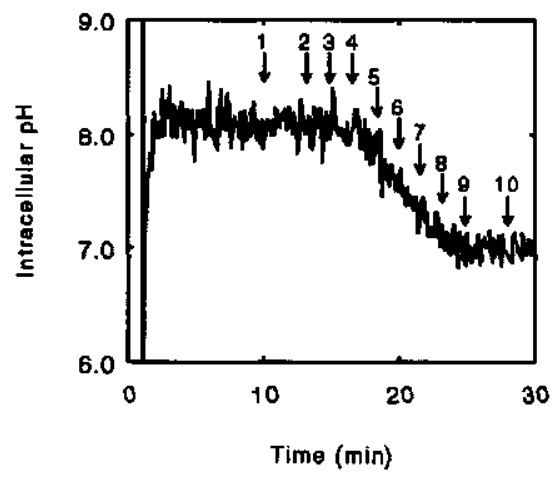

FIG. 1. The intracellular $\mathrm{pH}$ of $L$. lactis in $50 \mathrm{mM}$ potassium phosphate buffer $\mathrm{pH} 7.0$ in the presence of lactose $(10 \mathrm{mM})$. During the measurement the temperature was gradually increased to $54^{\circ} \mathrm{C}$. At the times indicated by the arrows the temperature (in ${ }^{\circ} \mathrm{C}$ ) in the cuvette was successively 32.4 , (1); 34.1, (2); 37.3, (3); 41.8, (4); 46.7, (5); 50.1, (6); 52.0, (7); 53.3, (8); 54.1, (9); and $54.1,(10)$. For more details concerning the $\mathrm{pH}_{\mathrm{in}}$ measurement see reference 9 .

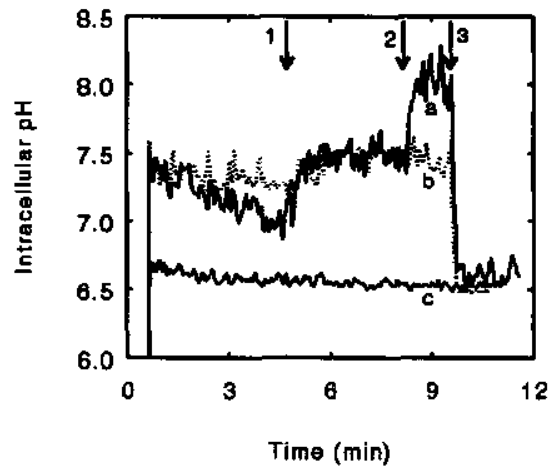

FIG. 2. Intracellular $\mathrm{pH}$ of $L$. lactis measured in $50 \mathrm{mM}$ potassium phosphate buffer (pH 6.5) at $30^{\circ} \mathrm{C}$. Prior to the measurement the cells were exposed to $60^{\circ} \mathrm{C}$ for $0 \mathrm{~min}(\mathrm{a}), 1 \mathrm{~min}(\mathrm{~b})$, or $4 \mathrm{~min}$ (c). The following additions were made at the times indicated by the arrows: 1, lactose $(10 \mathrm{mM}) ; 2$, valinomycin $(1 \mu \mathrm{M})$; and 3 , nigericin $(1 \mu \mathrm{M})$. For more details concerning the $\mathrm{pH}_{\mathrm{im}}$ measurement see reference 9 . 
respect to viability, a population can be arbitrarily divided in dead, viable but non-culturable, resting (dormant), and active (dividing) subpopulations (29). This categorization is principally based on differences in reproduction capacity of the cells. Fluorescence labelling techniques allow analysis of individual cells by microscopy, flow cytometry (FCM) or image analysis. Using FCM, Kaprelyants and Kell (21) showed that Micrococcus luteus cells were heterogeneous with respect to their ability to accumulate Rhodamine 123 . Two subpopulations could be distinguished: viable and non-viable cells. However, when the cells were resuscitated by addition of suitable nutrients, a part of the cells significantly increased their ability to accumulate Rhodamine 123 representing 'non-viable but resuscitable' cells.

A

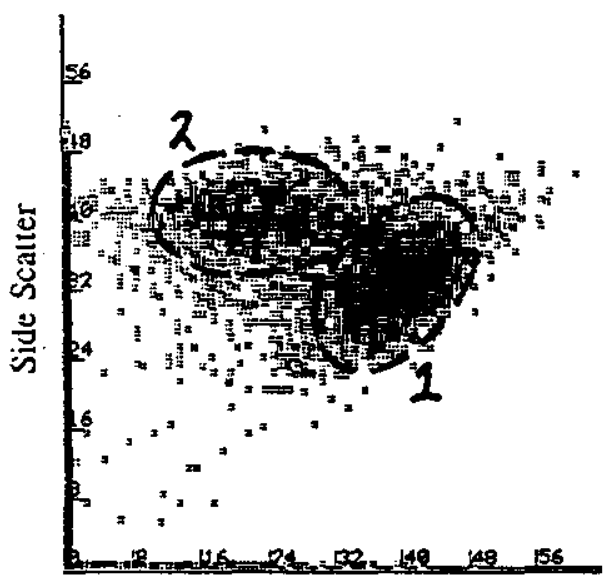

Forward Scatter
B

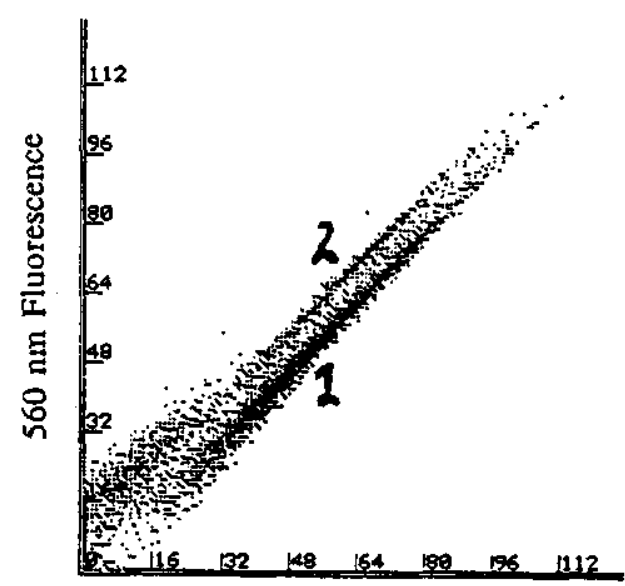

$515 \mathrm{~nm}$ Fluorescence

FIG. 3. Two parameter dot plots of the Side Scatter and Forward Scatter (A), and of the 515 fluorescence and the $560 \mathrm{~nm}$ fluorescence signals (B) of $R$. oligosporus sporangiospores. After $7 \mathrm{~h}$ incubation in malt extract in the presence of $0.05 \%$ acetic acid, two spore population are observed: (1) swollen spores (increased forward scatter) and higher $\mathrm{pH}_{\mathrm{in}}$ (high 515-to-560 $\mathrm{nm}$ ratio), and (2) small spores (decreased forward scatter) and lower $\mathrm{pH}_{\text {in }}$ (low 515 -to-560 nm ratio). The spores were stained prior to the measurement with $\mathrm{cF}$ by $10 \mathrm{~min}$ incubation in the presence of $0.22 \mathrm{mM} \mathrm{cFDA}$. The 515-to-560 nm ratio is representative for the $\mathrm{pH}_{\mathrm{in}}$. The $x$ and $y$ axes are on a 3 decade log scale divided arbitrarily in 64 (A) or 128 (B) channels. The excitation wavelength was $488 \mathrm{~nm}$. 
In Chapter 5 of this thesis it is shown that analysis of the germination of Rhizopus oligosporus sporangiospores indicated that spore populations are very heterogeneous. This could be demonstrated by assessment of the morphology and the $\mathrm{pH}_{\text {in }}$ of individual spores by FCM. Almost all spores germinated when incubated in malt extract whereas after incubation $(7 \mathrm{~h})$ in the presence of acetic acid $(0.05 \%)$, a population of swollen spores with high $\mathrm{pH}_{\mathrm{in}}$, and a population of small spores with lower $\mathrm{pH}_{\mathrm{in}}$ could be observed (Fig. 3). Furthermore, when in a separate experiment the spores were incubated in minimal medium clearly two populations could be detected; small, not germinating spores and swollen, germinating spores.

Similarly, a population of germinating spores of Bacillus subtilis could be distinguished in vegetative cells, germinated spores, and dormant spores by their uptake of ethidium bromide and light scatter characteristics (39). Dormant, non-germinating spores were not labelled by ethidium, whereas germinating spores were stained highly fluorescent. The vegetative cells could be distinguished from the spores by their decreased light scatter signal.

Heterogeneity of cells, originating from a genetically homogeneous population, has the obvious function to improve adaptation to unfavourable environmental conditions. Increasing technical capabilities provide new possibilities to study microbial population heterogeneity, and this may contribute to a better understanding of the mechanisms involved in selective survival of microorganisms under different stress conditions.

\section{References}

1. Arrick, B.A., and C.F. Nathan. 1984. Glutathion metabolism as a determinant of therapeutic efficacy: a review. Cancer Res. 44:4224-4232.

2. Balzi, E., and A. Goffeau. 1994. Genetics and biochemistry of yeast multidrug resistance. Biochim. Biophys. Acta 1187:152-162.

3. Blanc, V., K. Salah-Bey, M. Folcher, and C.J. Thompson. 1995. Molecular characterization and transcriptional analysis of a multidrug resistance gene cloned from the pristinamycin-producing organism, Streptomyces pristinaespiralis. Mol. Microbiol. 17:989-999.

4. Bolhuis, H., D. Molenaar, G. Poelarends, H.W. van Veen, B. Poolman, A.J.M. Driessen, and W.N. Konings. 1994. Proton motive force-driven and ATP-dependent drug extrusion systems in multidrug-resistant Lactococcus lactis. J. Bacteriol. 176:6957-6964.

5. Bolhuis, H., G. Poelarends, H.W. van Veen, B. Poolman, A.J.M. Driessen, and W.N. Konings. 1995. The Lactococcal $I m r P$ gene encodes a proton motive force-dependent drug transporter. J. Biol. Chem. 44:26092-26098.

6. Booth, I.R. 1985. Regulation of cytoplasmic pH in bacteria. Microbiol. Rev. 49:359-378.

7. Breeuwer, P., J.L. Drocourt, F.M. Rombouts, and T. Abee. 1994. Energy-dependent, carrier mediated extrusion of carboxyfluorescein from Saccharomyces cerevisiae allows rapid assessment of cell viability by flow cytometry. Appl. Environ. Microbiol. 60:1467-1472. 
8. Breeuwer, P., J.L. Drocourt, N. Bunschoten, M.H. Zwietering, F.M. Rombouts, and T. Abee. 1995. Characterization of uptake and hydrolysis of fluorescein diacetate and carboxyfluorescein diacetate by intracellular esterases in Saccharomyces cerevisiae, which result in accumulation of fluorescent product. Appl. Environ. Microbiol. 61:1614-1619.

9. Breeuwer, P., J.L. Drocourt, F.M. Rombouts, and T. Abee. 1996. A novel method for continuous determination of the intracellular $\mathrm{pH}$ in bacteria with the internally conjugated probe 5-(and-6)-carboxyfluorescein succinimidyl ester. Appl. Environ. Microbiol 62:178-183.

10. Breeuwer, $P$. Unpublished data.

11. Cole, S.P.C., G. Bhardwaj, J.H. Gerlach, J.E. Mackie, C.E. Grant, K.C. Almquist, A.J. Stewart, E.U. Kurz, A.M.V. Duncan, and R.G. Deeley. 1992. Overexpression of a transporter gene in a multidrug resistant human lung cancer cell line. Science 258:1650-1654.

12. Fath, M.J., and R. Kolter. 1993. ABC transporters: bacterial exporters. Microbiol. Rev. 57:995-1017.

13. Foster, J.W., and H.K. Hall. 1991. Inducible $\mathrm{pH}$ homeostasis and the acid tolerance response of Salmonella typhimurium. J. Bacteriol. 173:5129-5135.

14. Foster, J.W. 1995. Low $\mathrm{pH}$ adaptation and the acid tolerance response of Salmonella typhimurium. Critical Rev. Microbiol. 21:215-237.

15. Grinius, L., G. Dreguniene, E.B. Goldberg, C.-H. Liao, and S.J. Projan. 1992. A staphylococcal multidng resistance gene product is a member of a new protein family. Plasmid 27:119-129.

16. Guilfoile, P.G., and C.R. Hutchinson. 1991. A bacterial analog of the mdr gene of mammalian tumor cells is present in Streptomyces peutecius, the producer of daunonbicin and doxorubicin. Proc. Natl. Acad. Sci. USA 88:8553-8557.

17. Homolya, L., Z. Holló, U.A. Germann, I. Pastan, M.M. Gottesman, and B. Sarkadi. 1993. Fluorescent cellular indicators are extruded by the multidng resistance protein. J. Biol. Chem. 268:21493-21496.

18. Imai, T., and T. Ohno. 1995. The relationship between viability and intracellular pH in the yeast Saccharomyces cerevisiae. Appl. Environ. Microbiol. 61:3604-3608.

19. Ishikawa, T., and F. Ali-Osman. 1993. Glutathione-associated cis-diamminedichloroplatinum(II) metabolism and ATP-dependent efflux from Leukemia cells. J. Biol. Chem. 268:20116-20125.

20. Ishikawa, T. C.D. Wright, and H. Ishizuka. 1994. GS-X pump is functionally overexpressed in cisdiamminedichioroplatinum(II)-resistant Human Leukemia HL-60 cells and down-regulated by cell differentiation. J. Biol, Chem. 269:29085-29093.

21. Kaprelyants, A.S., and D.B. Kell. 1992. Rapid assessment of bacterial viability and vitality by thodamine 123 and flow cytometry. J. Appl. Bacteriol. 72:410-422.

22. Kell, D.B., H.M. Ryder, A.S. Kaprelyants, and H.V. Westerhoff. 1991. Quantifying heterogeneity: flow cytometry of bacterial cultures. Ant. Leeuwenhoek 60:145-158.

23. Kessel, D., W.T. Beck, D. Kukuruga, and V. Shulz. 1991. Characterization of multidrug resistance by fluorescent dyes. Cancer Res. 51:4665-4670.

24. Kobayashi, H., and T. Unemoto. 1980. Streptococcus faecalis mutants defective in regulation of cytoplasmic pH. J. Bacteriol. 143:1187-1193.

25. Lee, I.S., J.L. Slonczewski, and J.W. Foster. 1994. A low-pH-inducible, stationary-phase acid tolerance response in Salmonella typhimurium. J. Bacteriol. 176:1422-1426.

26. Lewis, K. 1994. Multidrug resistance pumps in bacteria: variations on a theme. Trends Biochem. Sci. 19:119-123.

27. Lloyd, D. 1993. Flow cytometry: a technique waiting for microbiologists, p. 1-10. In D. Lloyd (ed.), Flow Cytometry in Microbiology, Springer-Verlag, London, UK.

28. Markham, P.N., M. Ahmed, and A.A. Neyfakh. 1996. The drug-binding activity of the multidngresponding transcriptional regulator BmrR resides in its C-terminal domain. J. Bacteriol. 178:1473-1475.

29. Mason, C.A., G. Hamer, and J.D. Bryers. 1986. The death and lysis of microorganisms in environmental 
processes. FEMS Microbiol. Rev. 39:373-401.

30. Molenaar, D., H. Bolhuis,T. Abee, B. Poolman, and W.N. Konings. 1992. The efflux of a fluorescent probe is catalyzed by an ATP-driven extrusion system in Lactococcus lactis. J. Bacteriol. 174:3118-3124.

31. Müller, M., C. Meijer, G.J.R. Zaman, P. Borst, R.J. Scheper, N.H. Mulder, E.G.E. de Vries, and P.L.M. Jansen. 1994. Overexpression of the gene encoding the multidrug resistance-associated protein results in increased ATP-dependent glutathione S-conjugate transport. Proc. Natl. Acad. Sci. USA 91:13033-13037.

32. Neyfakh, A.A., V.E. Bidnenko, and L.B. Chen. 1991. Efflux-mediated multidrug resistance in Bacillus subtilis: similarities and dissimilarities with the mammalian system. Proc.Natl.Acad.Sci.USA 88:4781-4785.

33. Nikaido, H. 1994. Prevention of drug access to bacterial targets: permeability barriers and active efflux. Science 264:382-388.

34. Paulsen, I.T., and R.A. Skurray. 1993. Topology, structure and evolution of two families of proteins involved in antibiotic and antiseptic resistance in eucaryotes and prokaryotes - an analysis. Gene 124:1-11.

35. Poole, K. K. Krebes, C. McNally, and S. Neshat. 1993. Multiple antibiotic resistance in Pseudomonas aeruginosa: evidence for involvement of an efflux operon. J. Bacteriol. 175:7363-7372.

36. Rouch, D.A., D.S. Cram, D. DiBerardino, T.G. Littlejohn, and R.A. Skurray. 1990. Efflux-mediated antiseptic resistance gene gacA from Staphylococcus aureus: common ancestry with tetracycline- and sugartransport proteins. Mol. Microbiol. 4:2051-2062.

37. Saier, M.H., R. Tam, A. Reizer, and J. Reizer. 1994. Two novel families of bacterial proteins concemed with nodulation, cell division and transport. Mol. Microbiol. 11:841-847.

38. Salah-Bey, K., V. Blanc, and C.J. Thompson. 1995. Stress-activated expression of a Streptomyces pristinaespiralis multidug resistance gene (ptr) in various Streptomyces spp. and Escherichia coli. Mol. Microbiol. 17:1001-1012.

39. Ueckert, J., P. Breeuwer, T. Abee, P. Stephens, G. Nebe von Caron, and P.F. ter Steeg. 1995. Flow cytometry applications in physiological study and detection of foodbome microorganisms. Int. J. Food Microbiol. 28:317-326.

40. Van de Vossenberg, J.L.C.M., T. Ubbink-Kok, M.G.L. Elferink, A.J.M. Driessen, and W.N. Konings. 1995. Ion permeability of the cytoplasmic membrane limits the maximum growth temperaure of bacteria and archaea. Mol. Microbiol. 18:925-932.

41. Van Veen, H.W., H. Bolhuis, M. Putman, and W.N. Konings. 1996. Multidrug resistance in prokaryotes: molcular mechanisms of drug efflux. in press. $m$ W.N. Konings, J.S. Lolkema, and H.R. Kaback. (eds.), Handbook of Biological Physiscs, volume II: Transport processes in membranes. Elsevier Publishers, Amsterdam, The Netherlands.

42. Yerushalmi, H., M. Lebendiker, and S. Schuldiner. 1995. EmrE, an Escherichia coli 12-kDa multidrug transporter, exchanges toxic cations and $\mathrm{H}^{+}$and is soluble in organic solvents. J. Biol. Chem. 270:6856-6863.

43. Zaman, G.J.R., M.J. Flens, M.R. van Leusden, M. de Haas, H.S. Mülder, J. Lankelma, H.M. Pinedo, R.J. Scheper, F. Baas, H.J. Broxterman, and P. Borst. 1994. The human multidrug resistance-associated protein MRP is a plasma membrane drug-efflux pump. Proc. Natl. Acad. Sci. USA 91:8822-8826. 


\section{Summary}

Viability assessment of microorganisms is relevant for a wide variety of applications in industry, including quality assessment of starter cultures for beer, wine, and yoghurt production, evaluation of inactivation treatments, and biodegradation.

A number of methods are available to determine cell viability including the traditional plate count method and methylene blue staining, and more recently developed techniques such as the fluorescein diacetate method, respiration assays, and assessment of membrane potential. This thesis focuses on the application of fluorescence techniques for viability determination in general, but in particular on the energy-dependent efflux of fluorescent probes and determination of the intracellular $\mathrm{pH}\left(\mathrm{pH}_{\mathrm{in}}\right)$ with the fluorescent probe 5 (and 6-)-carboxyfluorescein succinimidyl ester (cFSE).

Fluorescent probes such as fluorescein, carboxyfluorescein (cF), and BCECF may be incorporated in microorganisms as (non-fluorescent) acetoxymethyl or diacetyl esters. These esters are membrane permeable and are cleaved in the cytoplasm by esterases, which results in accumulation of the fluorescent form. The mechanism of fluorescent staining of Saccharomyces cerevisiae by fluorescein diacetate and 5 (and 6-)-carboxyfluorescein diacetate (cFDA) was studied in detail. For fluorescein diacetate and cFDA permeability coefficients of $2.8 \times 10^{-7}$ and $1.3 \times 10^{-8} \mathrm{~ms}^{-1}$, respectively, could be calculated using Fick's law for simple diffusion. The accumulation of fluorescein is most likely limited by the esterase activity, since transport of fluorescein diacetate was faster than the hydrolysis rate. In contrast, accumulation of $\mathrm{cF}$ was limited by the much slower transport of cFDA through the cell envelope. The efflux of $\mathrm{cF}$ was stimulated by the addition of glucose and displayed Michaelis-Menten kinetics. A $\mathrm{K}_{\mathrm{m}}$ for $\mathrm{cF}$ transport of $0.25 \mathrm{mM}$ could be determined. The extrusion of $\mathrm{cF}$ was inhibited by the plasma membrane $\mathrm{H}^{+}$-ATPase inhibitors $N, N$-dicyclohexyl-carbodiimide and diethylstilbestrol and by high concentrations of tetraphenylphosphonium ions. These treatments resulted in a dissipation of the proton motive force, whereas the intracellular ATP concentration remained high. The transport of $\mathrm{cF}$ is therefore most probably driven by the membrane potential and/or the $\mathrm{pH}$ gradient. Since the $\mathrm{cF}$ extrusion is coupled to the energy metabolism this may give an indication of the viability of the cells. Subsequently, a two-step procedure was developed, consisting of loading the cells with $\mathrm{cF}$, followed by incubation at $40^{\circ} \mathrm{C}$ in the presence of glucose. The fluorescence intensity of the cells was subsequently analyzed by flow cytometry. The efflux experiments showed an excellent correlation between the viability of $S$. cerevisiae cells (determined by plate count) and the ability to translocate $\mathrm{cF}$. 
Currently, the most frequently used method to measure $\mathrm{pH}_{\text {in }}$ in bacteria is determination of the distribution of radiolabeled weak acids or bases in combination with silicon oil centrifugation. The disadvantages of this technique are the limited time resolution and the potential negative effects of weak acids on cell metabolism. Application of fluorescence techniques for $\mathrm{pH}_{\mathrm{in}}$ measurements have the advantage of a high time resolution and simplicity of use. In Chapter 4 , a novel method based on the intracellular conjugation of the fluorescent probe cFSE is described to determine the $\mathrm{pH}_{\text {in }}$ of bacteria. cFSE can be taken up by bacteria in the form of its diacetate ester 5 (and 6-)-carboxyfluorescein diacetate succinimidyl ester (cFDASE), which is subsequently hydrolysed by esterases to cFSE in the cytoplasm. Unbound probe could be conveniently extruded by a short incubation of the cells in the presence of a fermentable sugar, most likely by exploiting an active transport system. The $\mathrm{pH}_{\mathrm{in}}$ of the cells can be determined from the ratio of the fluorescence signal at the $\mathrm{pH}$ sensitive wavelength $(490 \mathrm{~nm})$ and the fluorescence signal at the $\mathrm{pH}$ insensitive wavelength $(440 \mathrm{~nm})$ of cFSE. The method was successfully used to determine the $\mathrm{pH}_{\text {in }}$ of Lactococcus lactis, Listeria innocua and Bacillus subtilis. In gram negative bacteria such as Escherichia coli, the use of the cFSE method may be complicated by the inability of the prefluorochrome cFDASE (molecular weight, 557) to pass the outer membrane of the gram negative cell envelope. A short incubation with EDTA can overcome this problem. However, EDTA treatment may well interfere with the active efflux of unbound cFSE and generation of a significant $\mathrm{pH}$ gradient. The principle advantage of cFSE is that leakage of the probe is minimal, being less than $25 \%$ for cFSE after 20 min at $30^{\circ} \mathrm{C}$, compared with over $90 \%$ for other analogs of fluorescein such as $\mathrm{cF}$ and BCECF. Significantly, incorporation and conjugation of cFSE in the cytoplasm of the cells does not affect the viability of the bacteria.

In Chapter 5, the germination of Rhizopus oligosporus sporangiospores and the mechanism of action of nonanoic acid, a self-inhibitor produced by various fungi, are investigated. The germination of $R$. oligosporus sporangiospores was determined microscopically and with flow cytometry. In malt extract broth the spores rapidly increased in size (swelling) as could be determined from the increase of the forward scatter in the side scatter/forward scatter dot plots. Swelling of the sporangiospores was accompanied by an increase of the $\mathrm{pH}_{\mathrm{in}}$. However, in the presence of nonanoic acid, increase of the $\mathrm{pH}_{\mathrm{in}}$ was prevented and swelling was inhibited. A model is proposed in which the $\mathrm{pH}_{\text {in }}$ plays a crucial role in the germination of $R$. oligosporus sporangiospores.

Detergents have a wide range of important applications both in biological research and in industrial processes. The effects of the non-ionic detergent Triton X-100 and the zwitterionic detergent Zwitterion SB 3-12 on the gram-positive bacteria $L$. lactis and $B$. subtilis were investigated. Both detergents efficiently inhibited growth at concentrations below the critical micelle concentration. Zwitterion SB 3-12 efficiently permeabilized $B$. subtilis and L. lactis, and Triton $\mathrm{X}-100$ induced lysis in $B$. subtilis. The cytoplasmic membrane of 
energized $L$. lactis is, however, not permeabilized by Triton $\mathrm{X}-100$ as demonstrated by (a) acidification of the extracellular medium $(\mathrm{pH}$ 5.8) by $L$. lactis after addition of lactose to the cells in the presence of Triton X-100, indicating that the lactose uptake system and the glycolytic enzymes functioned normally, (b) maintenance of intracellular ATP levels in the presence of Triton X-100, (c) negligible LDH activity in the extracellular medium after 1 hour incubation in the presence of Triton $\mathrm{X}-100$, and (d) maintenance of a $\mathrm{pH}$ gradient in the presence of high concentrations of Triton X-100. The resistance of $L$. lactis to Triton $\mathrm{X}-100$ is most likely due to the protective function of the cell wall, since protoplasts were very sensitive to permeabilization. There are several indications, however, that intact $L$. lactis cells require energy for their resistance to Triton X-100. Addition of lactose (10 mM) was necessary to restore the $\mathrm{pH}$ gradient, and minimalized leakage of $\mathrm{LDH}$ to the extracellular medium. Additional research is needed to determine whether resistance to Triton $\mathrm{X}-100$ in $L$. lactis is mediated by an energy-dependent extrusion system.

In the general discussion, the significance of energy-dependent extrusion systems in microorganisms, the potential of the $\mathrm{pH}_{\text {in }}$ for assessment of cell viability, and cell heterogeneity are discussed in detail. Fluorescent probes such as fluorescein, $\mathrm{cF}, \mathrm{BCECF}$, cFSE, rhodamine 6G, ethidium bromide, and BCECF-AM can be extruded from microorganisms by energy-dependent transport systems. These systems may frustrate labelling of microorganisms with fluorescent probes including DNA/RNA labelling, assessment of the $\mathrm{pH}_{\mathrm{in}}$, and determination of the membrane potential. On the other hand, these systems may be applied for viability assays. The $\mathrm{pH}_{\text {in }}$ is potentially a valuable parameter for cell viability. Indeed, several indications exist that the $\mathrm{pH}_{\text {in }}$ can be coupled directly to the growth rate of bacteria and yeasts. Finally, fluorescence techniques offer the possibility to study heterogeneity of a cell population employing microscopy, flow cytometry and image analysis. This may contribute to a better understanding of the mechanisms involved in selective survival of microorganisms under different stress conditions. 


\section{Samenvatting}

De bepaling van de levensvatbaarheid van micro-organismen is van groot belang voor de industrie. Hierbij kan gedacht worden aan de kwaliteitsbepaling van startercultures voor de produktie van bier, wijn en yoghurt, aan de afdoding van micro-organismen, en aan de afbraak van xenobiotica met behulp van micro-organismen.

Er bestaan meerdere methoden om de levensvatbaarheid van micro-organismen te bepalen, waaronder de traditionele plaatmethode, de methyleenblauw kleuring, maar ook nieuwere technieken zoals de fluoresceine diacetaat methode, het meten van de respiratie, en bepaling van de membraanpotentiaal. Dit proefschrift richt zich op de toepassing van fluorescentie-technieken voor de bepaling van de levensvatbaarheid in het algemeen, en in het bijzonder op energie-afhankelijke efflux van fluorescente probes uit cellen en de bepaling van de intracellulaire $\mathrm{pH}\left(\mathrm{pH}_{\text {in }}\right)$ met behulp van de fluorescente probe 5 (and 6-)carboxyfluoresceine succinimidyl ester (cFSE).

Fluorescente probes zoals fluoresceine, carboxyfluoresceine (cF), and BCECF zijn niet permeabel, maar micro-organismen kunnen wel worden opgeladen met de niet fluorescente acetoxymethyl- of diacetylesters van deze probes. Deze esters zijn membraanpermeabel en worden gesplitst door esterases aanwezig in het cytoplasma, met als gevolg ophoping van de fluorescente vorm. Het werkingsmechanisme van de fluorescente kleuring met fluoresceine diacetaat and 5 (and 6-)-carboxyfluoresceine diacetaat (cFDA) in Saccharomyces cerevisiae is uitvoerig bestudeerd. Met behulp van de wet van Fick kon een permeabiliteitscoefficiënt worden berekent van respectievelijk $2.8 \times 10^{-7}$ and $1.3 \times 10^{-8} \mathrm{~ms}^{-1}$ voor fluoresceinediacetaat en cFDA. Aangezien het transport over het membraan sneller is dan de hydrolysesnelheid is deze laatste factor waarschijnlijk de limiterende factor voor de ophoping van fluoresceine. Dit in tegenstelling tot de ophoping van $\mathrm{cF}$, waarbij de veel langzamere diffusie door het membraan de limiterende factor is. De efflux van carboxyfluoresceine kon worden gestimuleerd door toevoeging van glucose en worden beschreven met behulp van de Michaelis-Menten vergelijking. De berekende $\mathrm{K}_{\mathrm{m}}$ voor het $\mathrm{cF}$ transport was $0.25 \mathrm{mM}$.

De extrusie van $\mathrm{cF}$ werd geremd door de plasmamembraan $\mathrm{H}^{+}$-ATPase remmers $N, N^{\prime}$-dicyclohexyl-carbodiimide and diethylstilbestrol en door hoge concentraties tetrafenylfosfonium ionen. De protonen-drijvende kracht werd door deze stoffen gedissipeerd, terwijl de intracellulaire ATP concentratie hoog bleef. Het transport van $\mathrm{cF}$ is dus waarschijnlijk afhankelijk van de membraanpotentiaal en/of de $\mathrm{pH}$ gradiënt. Aangezien extrusie van $\mathrm{cF}$ is gekoppeld aan het energiemetabolisme kan deze extrusie mogelijk een indicatie 
geven van de levensvatbaarheid van de cellen. Daarom is een twee-stappen methode ontwikkeld, bestaande uit het opladen van de cellen met probe en vervolgens incubatie bij $40^{\circ} \mathrm{C}$ met glucose. Tijdens de incubatie wordt de fluorescentie-intensiteit van de cellen gemeten met behulp van flowcytometrie. In de experimenten werd een goede correlatie gevonden tussen levensvatbaarheid van de $S$. cerevisiae cellen (bepaald met de plaatmethode) en het vermogen van de cellen om $\mathrm{cF}$ te transporteren.

De meest gebruikte methode op dit moment om de $\mathrm{pH}_{\mathrm{in}}$ in bacteriën te meten is de bepaling van de distributie van radioaktief gelabelde zwakke zuren gecombineerd met centrifugatie door siliconenolie. Nadelen van deze techniek zijn de lage tijdsresolutie en de eventuele negatieve effecten van de zwakke zuren op het celmetabolisme. Fluorescentie-technieken daarentegen zijn eenvoudig toepasbaar en hebben het voordeel van een hele hoge tijdsresolutie. In Hoofdstuk 4 wordt een nieuwe methode beschreven om de $\mathrm{pH}_{\text {in }}$ in bacteriën te bepalen, gebaseerd op de intracellulaire conjugatie van de fluorescente probe cFSE. Bacteriën kunnen worden opgeladen met deze probe door incubatie met de diacetyl ester 5 (en 6-)-carboxyfluoresceine diacetaat succinimidyl ester (cFDASE). Na opname in de cellen wordt cFDASE gehydrolyseerd tot cFSE. Niet-gebonden probe kan eenvoudig uit de cel verwijderd worden door incubatie met een fermenteerbare suiker, waarschijnlijk door middel van een aktief-transport systeem. $\mathrm{De}_{\mathbf{p H}} \mathrm{kan}_{\mathrm{in}}$ worden bepaald door de ratio van het fluorescente cFSE signaal bij de $\mathrm{pH}$ gevoelige golflengte $(490 \mathrm{~nm})$ en het signaal bij de $\mathrm{pH}$ ongevoelige golflengte $(440 \mathrm{~nm})$. De methode is met succes gebruikt om de $\mathrm{pH}_{\text {in }}$ te meten in Lactococcus lactis, Listeria innocua en Bacillus subtilis. Voor gram-negatieve bacteriën, zoals bijvoorbeeld Escherichia coli is dit gecompliceerder omdat de prefluorochrome cFDASE (molecuulgewicht 557) net te groot is om ongehinderd de gram-negatieve buitenmembraan te passeren. Een korte incubatie met EDTA kan dit probleem verhelpen, maar EDTA kan een negatieve invloed hebben op de aktieve efflux van het ongebonden cFSE, en de $\mathrm{pH}$ gradient in de cellen. Het voordeel van cFSE is dat er relatief heel weinig cFSE (minder dan $25 \%$ na $20 \mathrm{~min}$ bij $30^{\circ} \mathrm{C}$, vergeleken bij $90 \%$ voor andere fluoresceine derivaten zoals cF en BCECF) uit de cellen lekt. De opname en conjugatie van cFSE heeft geen effect op de levensvatbaarheid van de bacteriën.

In Hoofdstuk 5 is gekeken naar de ontkieming van Rhizopus oligosporus sporangiosporen en het werkingsmechanisme van nonaanzuur. Nonaanzuur is een stof die door meerdere schimmels geproduceerd wordt om hun eigen ontkieming te remmen. De ontkieming van $R$. oligosporus sporangiospoten is gevolgd met behulp van microscopie en flowcytometrie. In moutextract bouillon werden de sporen snel groter (zwelling). Dit kon goed worden waargenomen door de toename van forward scatter in de side scatter/forward scatter dot plots. Tegelijk met de zwelling van de sporangiosporen nam de $\mathrm{pH}_{\text {in }}$ ook toe. Echter, de aanwezigheid van nonaanzuur verhinderde deze toename van de $\mathrm{pH}_{\mathrm{in}}$, en ook opzwelling van de sporen werd hierdoor belet. Met de resultaten werd een model voorgesteld voor de ontkieming van de sporen, waarin de $\mathrm{pH}_{\text {in }}$ een belangrijke rol speelt. 
Detergentia worden gebruikt voor een reeks van toepassingen zowel in biologisch onderzoek als in industriële processen. In Hoofdstuk 6 is gekeken naar het effect van de niet-ionogene detergent Triton X-100 en de zwitterionische detergent Zwitterion SB 3-12 op de gram-positieve bacteriën $L$. lactis en $B$. subtilis. Beide detergentia remmen efficiënt de groei van deze bacteriën bij een concentratie die lager is dan de CMC (critical micelle concentration). Zwitterion SB 3-12 permeabiliseerde $B$. subtilis en $L$. lactis, en Triton $\mathrm{X}-100$ induceerde lysis in $B$. subtilis. Er zijn echter verschillende aanwijzingen dat het cytoplasmatisch membraan van geënergeerde $L$. lactis cellen niet wordt gepermeabiliseerd door Triton X-100, zoals (a) verzuring van het extracellulaire medium ( $\mathrm{pH}$ 5.8) na toevoeging van lactose in aanwezigheid van Triton X-100; dit geeft aan dat glycolyse normaal functioneert, (b) het op peil houden van de ATP concentratie in de cellen in aanwezigheid van Triton X-100, (c) verwaarloosbare LDH activiteit in het extracellulaire medium na 1 uur incubatie met Triton X-100, en (d) het in stand houden van de $\mathrm{pH}$ gradient in aanwezigheid van een hoge Triton X-100 concentratie. Aangezien protoplasten heel gevoelig zijn voor permeabilisatie door Triton X-100, speelt de beschermende functie van de celwand waarschijnlijk een belangrijke rol in de resistentie van $L$. lactis tegen Triton $\mathrm{X}-100$. Er zijn echter aanwijzingen dat intacte $L$. lactis cellen energie nodig hebben om permeabilisatie door Triton X-100 tegen te gaan. Toevoeging van lactose $(10 \mathrm{mM})$ was noodzakelijk om de $\mathrm{pH}$ gradient weer op te bouwen na Triton X-100 toevoeging, en ook de LDH lekkage kon worden geminimaliseerd met lactose. Toekomstig onderzoek zal moeten uitwijzen of er energie-afhankelijke exportsystemen betrokken zijn bij de Triton X-100 resistentie van $L$. lactis.

De algemene discussie gaat in op het belang van energie-afhankelijke extrusie systemen in micro-organismen, de potentiële mogelijkheid om de levensvatbaarheid van cellen te bepalen met behulp van de $\mathrm{pH}_{\text {in }}$, en de heterogeniteit van celpopulaties. Fluorescente probes zoals fluoresceine, cF, BCECF, cFSE, Rhodamine 6G, ethidium bromide en BCECF-AM kunnen worden uitgescheiden door micro-organismen. Zulke uitscheidings-systemen systemen kunnen een goede fluorescente kleuring van micro-organismen, zoals DNA/RNA kleuring, bepaling van de $\mathrm{pH}_{\mathrm{in}}$ of membraanpotentiaal bemoeilijken. Aan de andere kant kunnen deze systemen mogelijk worden toegepast voor bepaling van de levensvatbaarheid. $\mathrm{De} \mathrm{pH}_{\text {in }}$ is potentieel een belangrijke parameter voor de levensvatbaarheid. Er zijn meerdere aanwijzingen dat de $\mathrm{pH}_{\text {in }}$ bepalend is voor de groeisnelheid van bacteriën en gisten. Fluorescente technieken, tenslotte, kunnen worden gebruikt om de heterogeniteit van celpopulaties te onderzoeken met behulp van flowcytometrie, microscopie en beeldanalyse. Dit alles kan bijdragen tot een beter begrip van de mechanismen betrokken bij de selectieve overleving van micro-organismen die zijn blootgesteld aan verschillende stresscondities. 


\section{Résumé}

L'évaluation de la viabilité des micro-organismes a un réel interêt pour divers domaines d'applications industriels, incluant le contrôle des inoculums pour la production de bière, de vin et de produits laitiers, ainsi que l'évaluation de traitement d'inactivation et de biodégradation.

De nombreuses méthodes sont disponibles afin de déterminer la viabilité cellulaire incluant la méthode traditionnelle de numération sur boîte de Pétri et la coloration au bleu de méthylène; Plus récemment, des techniques ont été développées: telles que le test de respiration, l'évaluation du potentiel de membrane et une méthode utilisant la fluorescéine diacétate. Cette thèse a pour but d'utiliser des techniques de fluorescence pour la détermination de la viabilité cellulaire en général. Plus particulièrement nous avons étudié l'efflux énergie dépendant de sondes fluorescentes et la détermination du $\mathrm{pH}$ intracellulaire $\left(\mathrm{pH}_{\mathrm{in}}\right)$ avec la sonde fluorescente 5(et 6)-carboxyfluorescéine succinimidyl ester (cFSE).

Des marqueurs fluorescents tels que la fluorescéine, la carboxyfluorescéine $(\mathrm{cF})$, et le BCECF peuvent être incorporés dans les micro-organismes sous la forme d'esters (non fluorescents) possédant des groupements diacétyl ou acétométhyl. Ces esters traversent la membrane et sont clivés par des estérases en composés fluorescents qui s'accumulent à l'intérieur du cytoplasme.

Nous avons étudié en détail le mécanisme du marquage fluorescent de Saccharomyces cerevisiae par la fluorescéine diacétate et le 5(et 6)-carboxyfluorescéine diacétate (cFDA). Les coefficients de perméabilité de la fluorescéine diacétate et du cFDA respectivement de 2,8 $10^{7}$ et $1,310^{8} \mathrm{~m} \cdot \mathrm{s}^{-1}$ peuvent être calculés en utilisant la loi de Fick de simple diffusion.

L'activité enzymatique des estérases est le facteur limitant de l'accumulation de la fluorescéine. En effet le transport de la fluorescéine diacétate est plus rapide que son taux d'hydrolyse. De façon opposée, l'accumulation de la $\mathrm{cF}$ est limité par un transport plus lent du cFDA à travers la membrane cellulaire. L'efflux du $\mathrm{cF}$ est stimulé par l'addition de glucose suivant une cinétique de Michaelis-Menten dont le $\mathrm{K}_{\mathrm{m}}$ est de $0,25 \mathrm{mM}$. L'expulsion du $\mathrm{cF}$ est inhibé par des inhibiteurs tels que le $\mathbf{N}, \mathbf{N}^{\prime}$-dicyclohexyl-carbodiimide et le diéthylstilbestrol et par de fortes concentrations d'ions tétraphénylphosphonium qui agissent au niveau de la pompe $\mathrm{H}^{+} /$ATP. Ces traitements entraînent la diminution de la force protomotrice tandis que la concentration en ATP intracellulaire reste élevée. Par conséquent, le transport du $\mathrm{cF}$ est plus probablement sous contrôle du potentiel de membrane et/ou du gradient de $\mathrm{pH}$. Comme l'efflux du cF est lié au métabolisme énergétique, celui-ci peut donner une indication sur la viabilité des cellules. Par la suite, nous avons développé un procédé en deux étapes, consistant à charger les cellules avec la cF et à les incuber à $40^{\circ} \mathrm{C}$ en présence de glucose. L'intensité de 
fluorescence des cellules est alors analysée par cytométrie de flux. Les expériences d'efflux montrent une excellente corrélation entre la viabilité des cellules de $S$. cerevisiae (déterminée par numération sur boîte de Pétri) et sa capacité à expulser le $\mathrm{cF}$.

La méthode la plus couramment utilisée pour mesurer le $\mathrm{pH}_{\mathrm{in}}$ des bactéries est la détermination de la distribution d'acides ou bases faibles radiomarquées avec une centrifugation en huile silicone. Les inconvénients de cette technique sont le temps de résolution limité et les effets négatifs potentiels des acides faibles sur le métabolisme cellulaire. L'application des techniques de fluorescence pour la mesure du $\mathrm{pH}_{\text {in }}$ ont l'avantage d'un temps de résolution rapide et d'une simplicité d'utilisation. Dans le chapitre 4, nous décrirons une nouvelle méthode basée sur les liaisons intracellulaires de la sonde fluorescente cFSE pour déterminer le $\mathrm{pH}_{\text {in }}$ des bactéries. Le cFSE peut être intégré par les bactéries sous la forme de son ester diacétate : 5(et 6)-carboxyfluorescéine diacétate succinimidyl ester (cFDASE) qui par la suite sera hydrolysé par des estérases en cFSE dans le cytoplasme. Le marqueur non lié peut être expulsé par une courte incubation des cellules en présence de sucre fermentescible, et ceci en exploitant le système de transport actif. $\mathrm{Le}_{\mathrm{pH}} \mathrm{in}_{\mathrm{in}}$ des cellules peut être déterminé à partir du rapport du signal de fluorescence à la longueur d'onde $\mathrm{pH}$ dépendant $(490 \mathrm{~nm})$ et le signal de fluorescence à la longueur d'onde $\mathrm{pH}$ indépendant $(440 \mathrm{~nm})$ du cFSE. La méthode à été utilisée avec succès pour déterminer le $\mathrm{pH}_{\mathrm{in}}$ de Lactococcus lactis, Listeria innocua et Bacillus subtilis. Dans les bactéries à gram négatif comme Escherichia coli, l'utilisation de la méthode cFSE peut être compliquée par l'incapacité du préfluorochrome cFDASE (poids moléculaire 557) à passer la membrane externe de l'enveloppe de la cellule gram négative. Une courte incubation en présence d'EDTA peut palier à ce problème. Quoi qu'il en soit, le traitement avec l'EDTA peut interférer avec un efflux actif du cFSE non lié et générer un gradient de $\mathrm{pH}$ significatif. L'avantage principal du cFSE est que cette sonde possède un efflux minimum, moins de $25 \%$ du cFSE ressort de la cellule après 20 minutes à $30^{\circ} \mathrm{C}$ en comparaison avec un efflux de plus de $90 \%$ pour les autres analogues de la fluorescéine comme le $\mathrm{cF}$ et le BCECF. L'incorporation et la liaison du cFSE au cytoplasme des cellules n'affecte pas la viabilité des bactéries de manière significative.

Dans le chapitre 5, nous étudierons la germination des sporangiospores de Rhizopus oligosporus et le mécanisme d'action de l'acide nonanoïc, un composé auto-inhibiteur produit par divers champignons. La germination des sporangiospores de $R$. oligosporus dans un milieu à l'extrait de malt est déterminé à l'aide d'une observation microscopique et par cytométrie de flux. Dans l'extrait de malt, la taille des spores croit rapidement (gonflement) comme cela peut être visualisé par l'augmentation du scatter aux petits angles dans la représentation graphique (scatter aux grands angles/ scatter aux petits angles). Le gonflement des sporangiospores est accompagné par une augmentation du $\mathrm{pH}_{\mathrm{in}}$, de même, en présence d'acide nonanoïc, l'augmentation du $\mathrm{pH}_{\text {in }} \mathrm{n}$ 'a pas lieu et le gonflement est inhibé. Une modélisation est proposée dans lequel le $\mathrm{pH}_{\mathrm{in}}$ joue un rôle crucial dans la germination des sporangiospores de R. oligosporus. 
Les détergents ont de nombreuses applications importantes que ce soit en recherche biologique et dans les procédés industriels. Nous avons étudié les effets du Triton $\mathrm{X}-100$, détergent non ionique et du Lauryl sulfobetaine, détergent zwitterionique sur les bactéries à gram positif $L$. lactis et $\boldsymbol{B}$. subtilis. Les deux détergents inhibent efficacement la croissance à une concentration inférieure à la concentration micellaire critique. Le Lauryl sulfobetaine perméabilise efficacement $B$. subtilis et $L$. lactis, le Triton X-100 induit la lyse chez $B$. subtilis.

Le Triton X-100 ne perméabilise pas la membrane cytoplasmique de $L$. lactis énergisé et ceci peut être démontré par (a) l'acidification du milieu extracellulaire par $L$. lactis après addition de lactose en présence de Triton $\mathrm{X}-100$, indiquant que le système de transport du lactose et des enzymes glycolytiques fonctionne normallement, (b) le maintien des niveaux d'ATP intracellulaires en présence de Triton X-100, (c) l'activité négligeable de LDH dans le milieu extracellulaire après 1 heure d'incubation en présence de Triton $X-100$, et (d) le maintien d'un gradient de $\mathrm{pH}$ en présence de hautes concentrations de Triton $\mathrm{X}-100(0,2 \%)$. La résistance de $L$. lactis au Triton $\mathrm{X}-100$ est plus particulièrement due à la fonction protectrice de l'enveloppe membranaire, puisque les protoplastes sont très sensibles à la perméabilisation. Par ailleurs, plusieurs expériences montrent que des cellules intactes de $L$. lactis demandent de l'énergie pour résister à l'action du Triton X-100. L'addition de lactose $(10 \mathrm{mM})$ est nécessaire pour rétablir le gradient de $\mathrm{pH}$, et minimiser la fuite de LDH vers le milieu extracellulaire. Des recherches complémentaires sont nécessaires pour déterminer si la résistance de $L$. lactis au Triton X-100 est effectuée par l'intermédiaire d'un système de transport énergie dépendant.

Dans la discussion générale, l'importance d'un système de transport énergie dépendant présent dans les micro-organismes, le potentiel du $\mathrm{pH}_{\text {in }}$ pour l'évaluation de la viabilité cellulaire, et l'hétérogénéité des cellules sont étudiées en détail. Des sondes fluorescentes comme la fluorescéine, la cF, le BCECF, la cFSE, la rhodamine 6G, le bromure d'éthidium, et le BCECF-AM peuvent être expulsés par des systèmes de transport énergie dépendant. Ces systèmes peuvent perturber le marquage des micro-organismes par des sondes fluorescentes comprenant des marquages $\mathrm{ADN} / \mathrm{ARN}$, l'évaluation du $\mathrm{pH}_{\text {in }}$ et la dêtermination du potentiel membranaire. D'un autre côté, ces systèmes peuvent être appliqués dans des tests de viabilité. Le $\mathrm{pH}_{\mathrm{in}}$ est un paramètre potentiellement valable pour la mesure de la viabilité cellulaire. Il existe vraiment plusieurs données montrant que le $\mathrm{pH}_{\text {in }}$ peut être relié directement au taux de croissance des bactéries et des levures. En conclusion les techniques fluorescentes offrent la possibilité d'étudier l'hétérogénéité d'une population cellulaire en utilisant la microscopie, la cytométrie de flux et l'analyse d'image. Ceci devrait contribuer à une meilleure compréhension des mécanismes impliqués dans la sélection des micro-organismes survivants à différentes conditions de stress. 


\section{Curriculum vitae}

Pieter Breeuwer werd geboren op 7 maart 1963 te Oosterbeek. Na het behalen van het Atheneum diploma aan de Willem de Zwijger scholengemeenschap in Papendrecht begon hij in 1982 met de studie Levenmiddelentechnologie aan de toenmalige Landbouwhogeschool te Wageningen. Zijn stage-periode bracht hij door bij het "Department of Food Science" aan de Universiteit van Guelph, te Canada. waarna hij in november 1988 afstudeerde aan de landbouwuniversiteit Wageningen.

$\mathrm{Na}$ de studie was hij kort werkzaam bij Chemunex B.V. in Den Haag, waarna hij van juli 1990 tot januari 1992 zijn vervangende militaire dienst verricht heeft bij de sectie Levensmiddelenchemie en -microbiologie van de Landbouwuniversiteit.

Van mei 1992 tot mei 1995 heeft hij gewerkt bij Chemunex S.A. in Maisons-Alfort, op zo'n twintig kilometer van het centrum van Parijs. Dit was in het kader van een "Training en Mobility Grant van de Europese gemeenschap", en in nauwe samenwerking met de sectie Levensmiddelen chemie en -microbiologie van de Landbouwuniversiteit. Aansluitend werd nog 18 maanden bij dezelfde sectie gewerkt als toegevoegd onderzoeker. In dit proefschrift is het onderzoek beschreven dat in deze vijf jaar is uitgevoerd.

Sinds 1 maart 1996 is hij werkzaam bij de eerder genoemde sectie als Post-doc aan een STW project getiteld: Ontwikkeling van fluorescente technieken voor de bepaling van de levensvatbaarheid en vitaliteit van melkzuurbacteriën en gisten in levensmiddelen. 
Résumé 